

\section{A sound family}

makes a sound StateKARIN NORMAN 

A SOUND FAMILY MAKES A SOUND STATE:

Ideology and Upbringing in a German Village

by Karin Norman

Doctoral Dissertation. By due permission of the Faculty of the Social Sciences of the University of Stockholm. To be publicly defended in Auditorium 9, House D, on Friday, March 15, 1991, at 10:00 a.m.

Stockholm Studies in Social Anthropology, 24

Department of Social Anthropology

University of Stockholm

S-106 91 Stockholm

Sweden

Stockholm 1991 ISBN 91-7146-881-1

\section{ABSTRACT}

This study concentrates on the ideas and values involved in the formation of children into 'good persons' as this is expressed and realized in a small German community through certain of their institutionalized practices. Upbringing and education, in German called Erziehung, receives a special force in Western societies through the particular institutions which have developed to cater to thought needs of the individual and of society. There is an ongoing discourse in Linden, as the village is called here, about how the individual relates, and should relate, to the social world as this is manifested in its various forms. The personforming project, as one may see Lindeners' preoccupation with upbringing and education, divulges a concern about the meaning and consequences of being social, of living under the dubious auspices of a State and in the shadow of a seemingly impenetrable and unavoidable past. Their concerns coincide with general Western ideas but are also of their own making. Throughout the descriptions this is an underlying theme.

In the daily of life of the Linden people the immediate practical experiences are those of being part of a family, working, attending school or kindergarten, going to church. These practices also form themselves into institutions in terms of social organization and roles, and are at the same time topics of discourse and 'lived realities'. These are imbued with notions about order and independence, obedience, love, guilt and blame, honesty and lying, as well as about biological heredity. The bulk of the ethnographic material comprises the interactions between adults and children within bounded settings, and adult ideas and values which shape and are shaped by these situations. In that sense it is not a study of children 'as such', that is, their internal and mutual world of interactions.

Fieldwork was conducted in central Germany between 1977-80. 



\section{A sound family}

IDEOLOGY AND UPBRINGING IN A GERMAN VILLAGE makes a sound State- 



\section{A sound family}

IDEOLOGY AND UPBRINGING IN A GERMAN VILLAGE

\section{makes a sound State-}

KARIN NORMAN

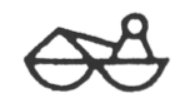

Stockholm Studies in Social Anthropology 1991 


\section{A SOUND FAMILY MAKES A SOUND STATE: \\ Ideology and Upbringing in a German Village}

Doctoral dissertation

Stockholm Studies in Social Anthropology, 24

(C) Karin Norman

Cover design by Tom Hultgren

Photos and diagram by the author

Department of Social Anthropology

University of Stockholm

S-106 91 Stockholm

All rights reserved. This book, or parts thereof, may not be reproduced in any form without the written permission of the author.

ISBN 91-7146-881-1

Layout and lazer-wiz by Tommy Dahlén

Printed by Gotab, Stockholm 1991 


\section{Contents}

Foreword

Introduction

1. Learning to be a person: introducing concepts

Problems of socialization and person 9

The individual in the society 15

Childhood and pedagogics in German thinking 19

Bringing up and educating: notions about Erziehung 28

Punishing and praising $\quad 32$

Order and independence 34

The necessity to learn: notions about lernen $\quad 40$

2. The place and people of Linden: a setting 44

Land and work: aspects of class and belonging 48

Ways of associating $\quad 55$

Municipality and local politics $\quad 58$

History, the past, and problems of identity 61

3. Separating and binding: the child at home 73

Household composition and family ties $\quad 74$

Mothers, Omas, and others $\quad 88$

$\begin{array}{ll}\text { Small children and the problem of dependence } & 94\end{array}$ 
A day in kindergarten 108

The newcomer 114

Mastering reality and being creative 119

Putting things in order: aufräumen 130

The performance of praise and punishment 133

5. Coping with pedagogics: the early school years 143

First grade, first day $\quad 145$

The German school and the school in Linden 150

Sarcasm and praise: constructing Ordnung in school 152

Asking and answering questions 162

Obstacles to learning and the problem of blame 165

$\begin{array}{ll}\text { Ordnung and the problem of difference } & 169\end{array}$

6. Encompassing the individual: claims of the church 176

Believing and going to church in Linden 178

Debating the moral body: a seminar on sexuality 184

Gemeinschaft and conformity among youth $\quad 189$

Dealing with modernity 193

Learning to be a Christian 199

$\begin{array}{ll}\text { 7. Concluding remarks } & 209\end{array}$

$\begin{array}{ll}\text { Notes } & 218\end{array}$

$\begin{array}{ll}\text { References } & 236\end{array}$

$\begin{array}{ll}\text { Index } & 247\end{array}$ 


\section{Foreword}

On November 9, 1989, the Berlin Wall fell, and pieces of the wall have found their way into the market. T-shirts with the text 'November 9 - I was there!' were soon selling. History is transformed into a commodity and we all seem to be enraptured by the thought of being able to buy it, own it, as a true sign of our freedom. ${ }^{1}$

The European world is being reconstructed and reformulated, the problem of the modern society and its history is a revived issue. There is, too, a kind of excitement; life isn't, after all, predetermined and predictable. In the midst of these events looms Germany, for some menacingly, for others with a certain hopeful potential. The 'German question', never answered unambiguously, has taken on new dimensions. It is not only a question of state politics concerning the relations between two (former) German states; it is a complex compilation of questions about Germany in the world, about German identity and the German nation. As, for example, Dahrendorf (1969) sees it, it is the problematics of German modern society and its relation to democracy. The last few decades, in particular the last ten-fifteen years, have produced a mass of texts concerning this whole subject of identity in West Germany (cf. Betz 1988, Öhgaard 1989).

The study on which this book is based does not deal with the more spectacular aspects of history and identity, but rather moves on the level of the seemingly unchanging trivialities of daily life, taking the institutional dimensions of bringing up children as essential experiences in forming and expressing the person in a modern Western society. This interest in problems of identity and forms of belonging coincides to some extent with earlier studies I have done in Sweden, one in a small northern village, another in a therapeutic community in Stockholm. My quest may partly be reformulated as a concern with the relation between individual and society as this is conceptualized or problematized by people. Westerners live in a world where the individual has historically emerged as ideologically set apart from, and in certain ways more highly valued than, the 
configurations we call society. Since Germany is, and has been, an influential and controversial part of the Western world, and by many scholars found to have its particular ideological brand (cf. for example Dumont 1986, Hughes 1977, Lukes 1979) it seemed to be an interesting challenge to do field work in Germany.

This challenge could never have been realized, either as fieldwork or as text, had it not been for all the help and support I have received from colleagues, friends and family throughout the years. And, above all, if it had not been for the people of Linden, the place of my fieldwork, and their kind acceptance of my presence and toleration of my curiosity.

In planning this project and getting it started, Karl Erik Knutsson, at the time head of the department of anthropology in Stockholm, gave me support and advice which I very much appreciate. Later, and throughout, Ulf Hannerz, head of the anthropology department, has supported my study and commented on a final version, for which I am grateful.

Sandra Wallman spent a few semesters in Stockholm as guest professor when I returned from the field and she made many helpful comments on some preliminary papers. Together with her and a few of my colleagues, in particular Mona Rosendahl and Gunilla Bjerén, I had many stimulating discussions and much fun.

Ulla Wagner was my supervisor during the first few years, until she was appointed director of the Ethnographic Museum in Stockholm. Times were a bit hard in those days and she very kindly and persistently saw to it that I did not lose my anthropological bearings. Things we talked about then have still proven to be relevant. During the later phases of this project Ulf Björklund has been my supervisor and I wish to thank him warmly for the help and good advice he has given me in organizing and re-organizing my text. I very much appreciate the interest he has shown my work as well as his critical eye for the worst inconsistencies and repetitions.

I have benefited from critique and encouragement from many colleagues and friends on different occasions. I wish to thank Peter Schweizer, who sadly died before this book could be completed. Also thanks to Bawa Yamba, Stefan Molund, Prudence Woodford-Berger, Kristina Bohman and Ann-Kristin Ekman. I discussed parts of my material with Camilla Hollander who gave me several interesting views on it. Also thanks to Solveig Freudenthal for the discussions we had a few times. Eva Evers Rosander has read parts of an earlier version and her comments, as well as her 
friendship and support to the bitter end, have been valuable to me. Tomas Gerholm read a more or less final version and I thank him for his comments.

At a crucial point I came into contact with Bruce Kapferer and his work. He very generously discussed my study with me and read parts of an earlier version. His comments and encouragement as well as his critical and sensitive relation to anthropology have meant a great deal to me. Dan Handelman kindly let me read parts of his manuscript to Models and Mirrors (1990), which was helpful.

I owe a very special thanks to Yngve Lithman and Aud Talle. Yngve Lithman, full as always of good ideas and enthusiasm, has engaged himself in my work in recent years. He has also read several versions of this study and his critical and encouraging comments have been invaluable. Aud Talle, with whom I have had many rewarding discussions, has also read several versions; her comments have been detailed and very helpful, and her questions illuminating. She has generously taken the time to interest herself in my work. I am greatly indebted to both of them, also for their friendship.

Johan Norman, my husband, has continuously been engaged in this prolonged work. His genuine interest and insight, as well as our common experience of Linden, have been very important to me. He has helped me stay on my feet when I have been ready to give it all up and for that I love him. I also thank Andreas and Ludvig Norman, my two sons, whose perseverance, judiciousness, and kind hearts I appreciate immensely.

Finally, and very specially, I want to thank Ulf V. Tidén. In truth, without his patience, tolerance and kindness I would never have been able to complete this study.

Patrick Hort has sensitively checked my English for mistakes and I thank him. Tommy Dahlén kindly and efficiently transformed my manuscript into laserprint.

Despite all the support and the many good and critical comments I have received from all these people, I must take full responsibility for the failings of even this final version.

I thank the local and regional officials of Bavaria for granting me permission to participate at various political, ecclesiastical and school meetings, and visit the local schools. The study was financed through grants from the Swedish Research Council for the Humanities and Social Sciences. 
All German names of people and places, except the larger wellknown cities, are pseudonymous. Even some other data, such as age of individuals or kind and place of work, etc. have been altered without changing the meaning of the presentation. This is meant to protect the identity of the Linden people. Unfortunately, it is not possible to do so completely, and the Lindeners and their neighbors are bound to recognize several of the people mentioned in the text. This study has its critical points and I can only hope they will not feel misrepresented. I must ask them to keep in mind that this is my interpretation of certain features of their social life. It is taken from a perspective limited by the questions I raised in relation to my understanding of particular problems which I encountered. It is not the only possible perspective. On the contrary, social life is diverse and complex and carries a wealth of meanings, of which only a few can be accommodated in any study.

All translations of German words and phrases are my own. German is richly descriptive and constructs many words through combinations of words, which makes them both seemingly very concrete and into labyrinths of meaning. It is difficult to reproduce this in a translation. I have therefore tried to make my translations literal rather than attempting to render them in good English. 


\section{Introduction}

Describing child upbringing and education can imply a variety of different analytical perspectives. In this study I concentrate on the ideas and values involved in the formation of children intc 'good persons' as this is expressed and realized in a small community in Germany through certain of their institutionalized practices. Upbringing and education receives a special force in Western societies, and so in Germany, through the particular institutions which have developed to cater to thought needs of the individual and of society. In that sense this is not a study of children 'as such', their internal and mutual world of interactions. Rather the bulk of the ethnographic material comprises the interactions between adults and children within bounded settings, and adult ideas and values which shape and are shaped by these situations. It is to the children we turn to tell ourselves about the ideals we adhere to, the norms we uphold, and the goals we seek. Having children is a very public matter, however much one may experience it as something personal and private. Children are essential parts of the social world and linked to society through the workings of institutions of the state.

Between 1977-80 I spent two years doing fieldwork in Germany, living in a Bavarian village which I here have named Linden. It is a densely populated part of northwestern Bavaria not so far from Frankfurt in Hesse. It was, as fieldwork usually seems to be, difficult and sometimes disconcerting, sometimes intriguing. Since my orientation from the beginning was about cultural identity, that somewhat amorphous term, the workings of upbringing and education became central for an understanding of notions about being a person and how this person is formed. I spent much time in the kindergarten and the schools, at meetings and gatherings arranged by the church or the school, but almost as often I went to political meetings, to feasts and informal gatherings. For a month I also worked in one of the small local industries. I visited a number of families, primarily having contact with the women, but there were few families that I really felt I 
came to know and feel at ease with. Family life was, on the whole, rather closed to me, perhaps because I had my own family with me. It seemed as if people felt that it wasn't right of me to be with others when I should be with my own family, taking care of my own children. And neither were they keen on having me intrude into their families, however hospitable they could sometimes be. ${ }^{1}$ It was then easier to attend meetings and larger gatherings than become a part of family life, which may have its disadvantage for the result of this study. This is not just a matter of closed families, however; it also has to do with class differences and being an outsider. The village, as the whole region, gives an impression of fairly equal economical conditions, there are no great class differences between people. But behind this seeming sameness there are differences of education, work, economical assets and political influence, which made themselves felt also in relation to myself. German social life, especially in regard to forms of school education, is often described and analyzed in terms of being very stratified, relations between different social categories being formal and restricted. Life in Linden is not heavily plagued by this but it is still a part of their reality and set its restrictions also on my own range of movement. Being a university person made me a bit difficult to place, particularly as I also was an outsider. I became both an asset and a nuisance, and I was at times quite unsure which it would be as I moved around the village.

\section{Anthropological studies of Germany}

Germany is a rather neglected area of study, at least among non-German anthropologists, even if there has been a small increase of studies since the seventies (mainly as unpublished theses, for example Eidson 1983, Gibson 1984, Roggenkamp 1986, Weatherford 1979). There is an obvious discrepancy between the interest shown other parts of Europe, where anthropologists have been conducting studies for many years, and the very few studies made in either of the German states (Forsythe 1986). Why is this, when Germans themselves are so concerned with their own situation and their own identity and position in relation to the rest of the Western world, and when other disciplines seem to find it worthwhile to make Germany a subject of study? Choosing to do fieldwork in Germany was not an unambiguous decision, and it was not always received with interest and enthusiasm. Perhaps in part, this is due to the notion that anthropologists should 
be on their way to more different worlds, the problem of difference being an essential part of our trade. More importantly, I think it has to do with the notions often held about Germans and the historical reality that has been created through them. The Germans have been dangerous in our modern history and their cultural world seems inscrutable. Inverting this, the Germans appear to be dull and uninteresting to non-Germans (cf.ibid.). As matters now stand in Europe, this seeming lack of interest will probably change.

Forsythe (ibid.; 1989) was often confronted by colleagues with the question 'why Germany?' when telling them about her new fieldwork. It was a kind of rhetorical question which she interpreted as an implication that Germans are uninteresting and not worth the effort. The point is that other choices of field do not seem to invite this kind of scepticism. I have met several such responses myself, often together with some joking about ridiculous or evil traits ascribed to Germans. This stands in quite stark contrast to the interest and admiration that has been shown German philosophers, writers and composers. The Nazi era, which in itself has been described and analyzed in "fifty thousand books and monographs" as Claudia Koonz mentions in her study of women in Nazi Germany (1988), sets its dismal mark on everything German. Perhaps it is also felt to be intellectually burdensome, since there is already so much said and done, what more can an anthropologist contribute? And how can one grasp that past reality in the reality of contemporary everyday life? A difficulty may also lie in the fact that studying Germans for a Western anthropologist means somehow having to cope with Nazism personally, however diffusely, as well as in relation to one's own society's past policy and more or less obscure ideology. ${ }^{2}$ Such questions and worries have haunted at least my own relation to this study.

Early anthropological studies of Germany were often concerned with 'national character', mainly in line with the Culture and Personality school. During the Second World War, and the years shortly after, studies of this orientation based themselves primarily on documents of various kinds, interviews with war prisoners and enclaves of immigrants, along with projective tests (Mead and Métraux, 1953), and analyses of films (Bateson 1953), children's stories and child rearing manuals (Métraux (1955) 1970ac), all of which was subsumed under the 'technique of studying culture at a distance' (Barnouw 1963, Mead and Métraux 1953). Other studies, like 
those of Rodnick (1948) and Lowie (1954), addressed the issue of national character without explicit analytical techniques, rather using material from shorter field visits and German literature.

Although the interest in national character studies has subsided in anthropology it still has its adherents in neighboring disciplines such as ethnology and folklore (for example, Dundes 1984; for a critique cf. Norman 1986), and has at least recently been "in vogue in political science" (Bock 1980:129). Above all, it is a part, at least implicitly, of much Western common sense thinking about other peoples, as well as about one's own people. Pinning down 'national types' is one of our convenient ways of explaining the social world to ourselves. Discussions about 'national mentalities' has connections with this kind of thinking although with perhaps a less explicit psychological orientation. The character becomes more of a cultural kind (cf. Daun 1989 on Swedishness), but even so the world of social practice is lost from view, or at least not problematized. The traits of the presumed mentality or character tend to be so generally descriptive and non-contextualized that they always seem to fit and social life becomes over-determined by more or less causal links assumed to exist between the individual mental world and the social and political processes (cf. Bock 1980, Dumont 1986a.).

Several later studies conducted in Germany have also considered questions of identity but stated, for example, in terms of modernization and urbanization (Cf. Golde 1975, Spindler 1973, Warren 1967), and in Spindler's case, psychologistically oriented. Family realtions and education have also been in focus (e.g. Rodnick 1948, Spindler 1973, Warren 1967, Weatherford 1979). However, fairly scant interest has been shown conflicts inherent in contemporary German life which in any deeper sense correspond to the issues many Germans themselves seem to be concerned with. An exception would be an orientation like that of Forsythe (1989). Dumont's work (1986a-c) is the most notable exception. He is one of the very few anthropologists who have raised more overarching questions about the relation between German history and German thinking. This has its significance for my study, since I consider certain aspects of this problem through my own empirical material. 


\section{The scope of the study}

There is an ongoing discourse in Linden about how the individual relates, and should relate, to the social world as this is manifested in its various forms. The person-forming project, as one may see Lindeners' preoccupation with upbringing and education, divulges a concern about the meaning and consequences of being social, of living under the dubious auspices of a state and in the shadow of a seemingly impenetrable and unavoidable past. Their concerns coincide with general Western ideas but are also of their own making. Throughout the different chapters this is an underlying theme, and in my thinking about this I have been inspired by Dumont's comparative analysis of individualist ideology and its particular German variant (1965, 1971, ibid.), as by Kapferer's (1988) critical development of Dumont's conception of ideology. But being inspired is not the same thing as explicitly using their models or showing their relevance. The workings of daily life, which is the focus of this study, do not easily lend themselves to more far-reaching assumptions about their links with an encompassing ideology. Therefore, although I attempt to point analytically beyond Linden, my choice of directions sometimes imposes a cautionary note. ${ }^{3}$

I have organized my material around recurring concepts which seem to summarize ideas and values about the person, something along the line of key cultural themes, and the main institutions in which these ideas and values come alive - the family, kindergarten, school, and church. They express and reproduce ways in which the individual is both made distinct from the collective yet subordinated a higher order, or 'a whole', and its authorities. Other institutions, such as the voluntary associations, and various public events, are also significant in this respect although they do not have as pronounced educative ambitions and do not affect children's lives as do, for example, kindergarten and school.

Chapter 1 is in some ways an introductory chapter in that it deals with those concepts which appear to be central for the understanding of Linden notions about what makes the child into a good person. Before focusing on the Lindeners' own concepts about upbringing, order, learning, which I deal with quite extensively already in this first chapter, I briefly consider aspects of person and socialization in anthropology. I present certain themes in earlier German educational ideology as it appears in the writings of some pedagogues and philosophers in the 19th and early 20th century. This is not meant to be an history of pedagogical ideas, 
which would be beyond the aim of this study. Rather, I find connections between ideas and values which are prevalent in Linden and those more ambitious attempts to plea for an upbringing and education in the interests of the nation and of the state. In the subsequent chapters, I do not explicitly keep referring to these early writers, but the analysis is meant to revolve around problems raised in chapter 1.

Since the main descriptions concentrate on events within the realm of specific institutions, other aspects of Linden life fall into the background. Chapter 2 is then a general setting to give an idea of 'what it is like' in Linden through descriptions of work, ways of associating, local politics, and notions of identity and history linking people to processes outside Linden. It is an attempt to indirectly contextualize the ethnography of the other chapters.

Chapter 3 turns to the family and the household, the house and home being very important to people and the primary context within which the small child moves. Much of life circulates around family relations and contact with close kin. The small child is kept close to the home in an ambivalently close relation to the mother and the grand-mother, the Oma, two central figures throughout people's lives and significant for this analysis.

The kindergarten is the first extra-familial arena where the child regularly appears on its own and this is then the focus of chapter 4. Although several contexts can be formulated in terms of learning, the kindergarten is explicitly set on teaching the child to learn. The child enters a world where boundaries between various activities and capabilities are constantly made specific. In this way the child begins to be made more aware of the demands set on being a person in Linden. It must learn the order of things and relations, become part of a group and abandon its self-centeredness and dependence on the mother.

In chapter 5 themes about order and learning, which are already prevalent in kindergarten, recur and are amplified through descriptions of school situations. Even if the kindergarten has closer or more direct ties with the family, it is the school which is felt to be most demanding on the family. Relations between school and parents are generally formal and restricted. The child's achievements are felt by teachers to relate to the status of the parents' capabilities to bring up their children. Such potential judgements may be feared or resented by parents and may lead them to 
increase their demands on their children, since they have few other means to influence teachers. The teachers, in turn, may feel controlled by parents, but their more potent controller is the state, since teachers are civil servants and expected to act with loyalty towards the state. I describe and use several events to convey forms of interaction between teachers and children and teachers and parents, thereby attempting to make explicit the ideology which lends these forms some of their cultural logic. This connects the school to kindergarten and to the encompassing claims of the church, which is the topic of the following chapter.

The church in Linden, as it is described in chapter 6, reinforces school and kindergarten educational ideology and sanctions the good family. Through various activities, often directed by the priest himself, the church claims its place in defining the modern society. The attention devoted to children and youth manifests and reproduces notions of belief, Gemeinschaft (local solidarity, belonging), and modernity. The order of God, belief and trust in Jesus, is an influential aspect in Linden, socially and politically, and becomes particularly strong in relation to the upbringing and education of children. The church cannot be excluded from the formation of the good and trustworthy person and the good society.

Throughout the different chapters the problematics of order, Ordnung, as an overarching cultural theme in Germany, is continuously referred to. Ordnung is something which in particular sets its mark on the management of the body. Through the control and manipulation of the body, and of notions about the body, the person is chiselled out and fused with 'society', society is embodied in the person, as it were. 


\section{Learning to be a person: introducing concepts}

In the daily life of the Linden people the immediate practical experiences are those of being part of a family, working, attending school or kindergarten, going to church. These practices also form themselves into institutions in terms of social organization and roles, and are at the same time topics of discourse and 'lived realities'. They convey ideas and conceptions about the world, about the person, about being German. These entail notions about order and independence, obedience, love, guilt and blame, honesty and lying, as well as about biological heredity. And all of this is part of the gigantic project called Erziehung, upbringing and education.

In Western societies there is a great preoccupation with techniques of child rearing and of defining what a child is, what is or is not natural or normal in its development. ${ }^{1}$ There are rival schools of how best to rear one's child, there are endless discussions and political decisions about education, its form and content. Bringing up children is hard work demanding that the upbringers themselves be educated for it. Cadres of experts are engaged on different levels of this state controlled pedagogical project of making people 'real'. Ideals are set high and often perceived as not being fulfilled, which perhaps also underlies the sense of cultural and social crisis proclaimed recurringly in our different societies, not just in Germany. Looked at comparatively, that is, in relation to studies done in non-Western societies, it becomes clear that this is not a universal mode 
of relating to children. ${ }^{2}$ Neither is it based on a universal mode of conceptualizing the person, an issue with which anthropologists seem to be more and more concerned. ${ }^{3}$

\section{Problems of socialization and the person}

Several studies and reviews which consider the standing of the concept and study of socialization have appeared, and there have been many ethnographic accounts of child life since the early descriptions by Fortes of Tallensi education (1938) and Mead's even earlier studies of growing up in New Guinea (1930). ${ }^{4}$

The concept of socialization is problematical partly because it works with notions of effect, that certain acts and behaviors have certain effects on later acts and behavior. To disentangle in which relation behavior stands to thought and emotions is a complex problem. To what extent are children's activities, and play, a result of what adults do and say to them? And to what extent do children make their own interpretations and create their own experiences? They may perhaps confound the adults' intentions for the whole child-rearing project. ${ }^{5}$ Socialization implies conceptions of learning, making competent; as Jahoda and Lewis have expressed it, "the common core of meaning (of socialization among psychologists and anthropologists) is the process whereby children become effectively functioning members of a particular society" (1985:19). Children are, it seems, always becoming something, whereas adults have become, they are, kinds of finished products.

Traditionally, then, socialization studies have tended to see children and adults as separate entities, where children are to learn the rules and roles the adults present them in order that they may become significant social actors. "Sociologically, unless he is a 'delinquent' the child is passive", as Schildkrout says in her critique of this perspective (1978:109). Socialization becomes a closed system with particular means and ends, instead of something more open-ended, where children are seen as creating the world they live in and interacting with adults. Thereby children also form adults rather than just being recipients of various measures. ${ }^{6}$ Many ethnographic studies of children and childhood do not actually motivate this passive recipient-view, as Schildkrout notes, but analysis has perhaps been hampered by not asking such questions as Schildkrout deems neces- 
sary: "In what ways are adults dependent upon children? What is the significance of children in maintaining the relative status of men and women? Why do people want or need children?" (ibid.:111). Schildkrout's primary interest is in economic relations but the questions, and derivatives of them, have relevance also for other aspects of social life.

Actually, my own study is not intended as a study of socialization, although it unavoidably becomes a part of this tradition, since it takes ideas and practices of educational institutions as its point of departure for a look at how the 'good' (or 'real') person is to be formed. The children of Linden may then appear as 'passive recipients', which points to problems with my study. It becomes somehow detached from the people as I look at the fragments of a more encompassing ideology of the individual and society, and the tremendous concern with Erziehung which different categories of Linden people show, as if this were a means for adults to recreate their reality. But I do not consider children to be just learners. Children and adults live simultaneously, shaping each others' lives, yet often at odds with each other, and having some painful difficulties understanding one another. It is intriguing to consider how adults strive to define reality for their children, but it is, as I have mentioned, much more difficult to pin down how this works on the children themselves, that is, how they experience it. My study stops short of that. In this way I limit myself to regarding acts of teaching and bringing up from an adult perspective. As I see it this perspective is part of an ideological discourse which extends beyond the limits of Linden.

Several studies of socialization enquire into such 'reality formation' from different analytical perspectives (for example, Heath 1983, Hendry 1986, Ochs and Schieffelin 1987) which I find illuminating in considering my own material. Heath (ibid.), for example, in her comparison of white working-class people in the North American South with the black people of a neighboring community, found them adhering to quite different notions of 'teaching about reality'. The white people are concerned with a 'real' world, not something 'make believe', and take great pains tobring up their children. In contrast, the black people rather see their children as 'comin' up' and so do not explicitly attempt to teach them; each child is thought to have 'the makings of something' over which adults have only limited influence. In turn, Ochs and Schieffelin (ibid.) discuss the extent to which children are expected to adapt to situations rather than adapting situations 
to the children. It is noted that white middle-class Western parents tend to accomodate to young children as the latter's needs are interpreted, intent on forms of prevention and intervention, whereas their Kaluli and Samoan counterparts do not deem it possible to place themselves in the child's position. They interact with their small children in ways thought to make the latter competent to handle the adult's position, not explicitly adjusting themselves to perceived needs and wishes of the child. ${ }^{7}$

On the whole, children of all ages in Linden, but particularly the younger ones, must learn to cope with the world around them 'as it is', situations are not re-oriented to suit the child. The glass vase is not moved from the coffee table when the one-year old tries to get ahold of it. Instead the child is told repeatedly 'no, no', and finally fingers are slapped. Somewhat older children playing together, getting quite wild and boisterous will seldom be told to stop, but neither will they be comforted when later hurt and complaining loudly or tearfully. The child will hear that it can only blame itself - du bist selbst dran Schuld ('it's your own fault'), perhaps laughed at or scolded. There seems to be a fairly strong tendency to make the child socially competent, demanding that it understand the situation as it is understood and judged by the other, the adult primarily. The adult - parent, teacher, priest - becomes a necessary and idealized mediator between the child and the reality. There are ideals to be adhered to and the child cannot detect them on its own without guidance. And in turn the parent or teacher must be guided and controlled by experts - reproducing a long chain of controlling agents who are less and less personal.

Socialization implies the importance of conceptions about the person and the self, but these conceptions are difficult to define and to work with. In earlier anthropological studies of socialization this was not a prominent theoretical focus other than in the Culture and Personality tradition of searching for universal personality structures (Barnouw 1963). The person was rather a subject matter of its own, so to speak, and could, for example, be analyzed in terms of summaries of social statuses. Later studies, such as those of Riesman (1977) and Rosaldo (1980), and Howell (1985), are more oriented towards the problem of the self, the formation of the experiencing self. This, I think, goes hand in hand with the growing awareness of the anthropologist as a person and an experiencing self. Riesman (ibid.) and Rosaldo (ibid.) go beyond any narrow socialization perspective in an attempt to come close to notions about the self through the way emotions 
and life experiences are conceptualized. So, now it is no longer just 'the person as a complex of social relationships' distinct from the 'individual as a biological organism' (as Radcliffe-Brown saw it, cf. La Fontaine 1985) which is at issue in anthropology, but also the reflecting, emotional, and troublesome aspect of being a person. Howell (1990) has recently reconsidered the problem of person and self in terms of what it means to people to be human, how human nature is conceptualized and valuated, referring to questions which profoundly engaged some of the early anthropologists. From that vantage point, it does not appear necessary to take a definite stance as to the various meanings or definitions anthropologists give such concepts as person, individual, or self. The implication is rather to concentrate on the ideas people have of themselves. Harris (1989), however, who is critical of anthropologists' tendency to conflate these concepts, strives to distinguish them. She claims the necessity of distinguishing between biological, psychological and sociological concepts as they appear in 'any local system' in relation to such Western conceptions. This may be important if the comparative perspective is to be included in the problem, although it may perhaps also risk reifying distinctions which are not relevant in any local system. She adheres to the notion of the person as an agent-insociety, "the author of action purposively directed toward a goal", whereas the individual is "a single member of the human kind and the self is the locus of experience" (ibid.: 601-602), corresponding to sociologistic, biologistic and psychologistic notions respectivley. I take it that making such distinctions is not to be understood as if people are either persons or individuals or selves, but that conceptualizations of these aspects of being human in the world differ. The boundaries of being human, as those of the world, are differently drawn. The question is what tools the anthropologist has for discovering and interpreting these variations and differences.

The concept of person is central for my analysis, but the usage is not without problems. As I sometimes tend to think about the person, the concept merges with that of individual and self. However, I do find merit in keeping them analytically separate, even if this proves difficult to manage in description. Dumont $(1965,1986 a)$ uses the term individual in two ways, both as the empirical subject who thinks, speaks and feels, and as a culturally constituted moral entity basic to Western ideas and valuations about the relation between Man and society, the individual of our individualistic ideology. This latter ideological construct is what Strathern (1982) refers 
to as the person, retaining the concept of individual for the sentient, empirical subject (thereby differing from Harris). My own approach is likewise to consider the person as an ideological construct, whereas the individual has more of the characteristics of the empirical subject (cf. Kapferer 1988). As has been pointed out several times before, it is not possible for the anthropologist to gain complete access to inner experiences, the world of the self, but we can gain access to how people conceptualize thought and emotions, the ideas and valuations they have about themselves and others and how one should be and act to be 'good' or 'real' in the social world one inhabits. ${ }^{8}$ This would then apply to notions about the construction, the formation, of the person. My focus in this study is the ideas people of Linden have of what it takes to be ein Mensch ('a human, a (good) person'), one could say, and so in a particular way German, and how these ideas are reproduced in different forms of interaction and in different situations. Thereby experiences of the individual are made which complicate the person-forming project and which may blur and hide the aims and goals actors have or believe others have.

As an ideological construct the person does not appear strongly gendered in Linden. That is, even if men and women in practice 'work the system' differently and people and actions are imbued with notions about male and female, men and women share ideas and values about what a person is and how it is formed (cf. Strathern 1982). For example, in kindergarten, even if it is generally significant whether a child is a boy or a girl, children are not particularly noted for their male or female traits. A boy is admonished to stop crying, for example, not because he is first of all a boy but because there are other children younger than he who are not crying. Taking another example, learning the necessity of order and the virtue of being independent applies to both the female and the male child. Boys and girls are different, but ideologically they are not thought of as needing very different kinds of upbringing to become good persons. In practice gender distinctions become more essential as the children become adolescents and in adult life.

Women of differing categories have been my main source of information and were those with whom I mostly interacted, but the question of gender has not been explicitly problematized in my analysis. The children in my study are not noted for their specific male or female traits or views, nor are means and aims with the upbringing systematically distinguished 
along male/female lines, although it is here and there pointed out in which ways girls and boys tend to behave and accomplish. In my perspective on the ideology of making persons the problem of age as an essential social position stands out as very significant, tending to take gender more of a given aspect of the relations. That is, in Linden there is a crucial difference in life between being an adult and being a child. In relation to this, being man or woman, girl or boy, does not carry quite the same weight as it may do in other aspects of life. This is perhaps forcing the point, but Erziehung, as a cultural project, assumes that there are individuals in society who must be formed in a particular way so that a social order can be upheld, and that these individuals will not form themselves into desirable persons. The older must then take the responsibility of forming the younger. Granted that it makes a difference whether the older is a man or a woman, in certain positions maleness or femaleness is not the most important distinction. ${ }^{9}$

The Lindeners' notions about the person and its problematic relation to the social world, 'society', link them to an overarching ideological discourse of the modern Western world and its particular German variant which Dumont (1986a) analyzes. The person may not be a distinct entity in people's minds in Germany or the Western world, but there is still an overall ideological adherence to certain notions about the person as a bounded, independent, rational being who acts and chooses according to a free will, and who is responsible for his or her actions (cf. Lukes 1985). The person is somehow made autonomous in relation to the social world. People may also have views which seem to contradict this, namely that the person is socially determined or subordinated to 'fate and destiny', or constrained by biological heredity. These views may be seen as ways of managing prevalent values of individual autonomy and equality in relation to forms of subordination and differences which confront people all the time. However bounded and defined 'personhood' may be, the person on the ground becomes much more complex and elusive, for there those contradictions come alive which people must continuously cope with.

In the modern Western world the individual is not conceived of as primarily being subordinated to or dependent on the social world, but as being something unique on which the social world depends (and there arises here a problematic split between what is taken to be 'society' and what is taken to be a person). Children are not brought up only to shoul- 
der a pre-formed position, bringing up a child is to mold something special. The Western world is not one and the same, but such an overarching individualistic ideology has set its mark on our conceptions of ourselves and our neighbors. If this individualism has in recent centuries become a central mode of thinking about the world and of valuating it in Western societies, and if this individualistic ideology is differently formulated in the various cultures of the West, where then does Germany come in? How is 'German individualism' constituted? And how does this relate to the everyday workings of Erziehung in Linden?

\section{The individual in the society}

Since it is not sufficient for people of Linden, nor then for me, that they are just Linden people, I find it relevant to consider them, their ideas and actions in a wider ideological context. The people of Linden refer to themselves as Germans in relation to a non-German world and it is through this awareness that their adherence to Linden acquires a deeper significance. 'To be German' is perhaps not felt to be a daily concern for the Lindeners, but not far from it - they were at least often reminded of its inherent problematics through newspapers and television reporting on Nazi trials, the police search for the RAF-terrorists (Rote Armee Fraktion, Red Army Fraction), the educational reform, and relations with East Germany - now brought to a head through the transformation and subsequent dissolution of the German Democratic Republic during 1989-90.

Germany is usually considered as somewhat set apart from the other Western nations, and national concerns have a specific standing in Germany, now again brought into focus through the reunion of the two German states. ${ }^{10}$ German 'modern ideology' as it developed during the 18th and 19 th centuries was marked by the contradictory notions of man as a social being and man as a unique individual (Dumont 1986a-c), and this stood in a complicated relation to the social and political reality of the time, a reality characterized by historians as lacking political unity and with comparatively late, but fast industrialization. The belated political unification into the Prussian state came under Bismarck. The middle class was politically fairly weak and uninfluential, whereas there was a socially dominant militarism. Sets of social reform were instigated not through revolution but initially from above. During the early 19th century nationalism began to 
flourish and it rotated around ideas about German unity and the German spirit as embodying humanity, of individual freedom through integration with the Volk (cf. Bramsted 1972, Dumont ibid., Mosse 1966).

Certain themes are recurringly emphasized when the development of modern Germany is to be explained, focus unavoidably being on the disputed forerunners of National Socialism. The Enlightenment, a landmarking era of sorts in modern European history, was differently conceived of in Germany and the rest of Western Europe - the rationalism and the idea of universal progress in connection with it did not find acceptance among many German scholars. The period of Romanticism had its 'origins within the age of reason itself' (Mosse 1963) and found some of its energy in its reaction to the French Revolution and the upheavals of the Napoleonic times. Although not a uniquely German phenomenon, this period is held forth as a particular blossoming of German thought. And some of the social philosophers at this time, such as Herder and Fichte (developing in different directions), were keenly aware of the ideologies of equality and liberty of the French Revolution and were also preoccupied with the problematics of national unity and a German cultural identity.

In German ideology, as writers such as Dumont see it, there appears the contradictory view of conceptualizing man both as an abstract embodiment of humanity, that is, as an 'individual' (not in the sense of the empirical subject) and as a social being whose humanity is dependent on the particular society in which one lives. In this thought there is a tendency to consider a certain people as a representative of humanity as such, as being more prominent than others. There is then a 'pan-Germanism' which is cherished instead of a universalism among social philosophers such as Fichte. That which is German becomes more important in relation to other peoples than a sense of equality, the prime value of individualism. It is a kind of preoccupation with the world, with a position in the world which would differ from the French more clear-cut egalitarianism of individualism, according to Dumont (1986a).

It may seem logical to interpret the rapid technological and economic development in Germany as a reinforcer of individualism, but at least among intellectuals there was rather a counter-reaction to bourgeois economism and 'Westernization', taken as a 'denaturalization' of Germany (cf. Ringer 1969), and ideological dilemmas of this kind were intensified through the outcome of the First World War. It was in relation to these 
contradictions that the "pseudo-holism" of Nazism was possible, according to Dumont (1986a). Dumont argues that there are certain basic structures in modern German ideology created through history, a view which he shares with several other writers on Germany. And his deepest concern is to understand German ideology so as also to understand the possibility and actuality - of totalitarianism and of Nazism, which he sees as a clearly modern phenomenon (cf. Dahrendorf 1969). That is, it is a possibility of individualism and not an outgrowth of holism, however much totalitarianism may appear to build on a kind of holisitic ideology. In relation to his analyses the problem of difference is central, how differences between peoples are understood and handled. The prime value of individualism is that of equality, the idea of the autonomous and freely choosing individual who moves and changes society, so to speak, and is equal to all other individuals, there is then no difference. Yet there are differences, we experience them all the time, and we must cope with them, name them, explain them.

Difference entails both inclusion and exclusion, each person, community or society, and nation is a bounded unit exclusive of others yet principally equal in terms of autonomy and uniqueness. To belong is to be the same, there is little toleration of internal conflict. One can here briefly consider just a few German writers on this subject, one which obviously and interestingly troubles them. Dahrendorf deplores what he calls a "nostalgia for synthesis" (1969:195) in German social and political life, an aversion of internal conflicts and a traditional striving for national unity at all costs. Whereas Claessens et al. (1978) are somewhat pessimistic as to the possiblity of West German society to solve the social conflicts which emerge in the shadow of economic growth and political stability. Their scepticism rests on the view that there is still a widespread, and very objectionable Harmonieglaube ('belief in harmony') in Germany which entails an intolerance of internal conflicts. Greiffenhagen (1981), discussing political culture in Germany, find a strong avoidance of conflict yet a very loud and unfriendly tone of debate among politicians, an intolerance of difference, which is assumed to be a reflection.of society at large. On the other hand, with an anger and fearlessness which are recognizable among many intellectuals of the left (that somewhat vague but until now, at least, forceful term), Lohman (1989) writes about the 'trauma of violence' in German society, in memory of Peter Brückner, (the politically controver- 
sial social psychologist during the seventies, accused by the state of being a terrorist sympathizer).

Bringing up children is a way of interpreting and reproducing relations referring to a higher order, that of the state and the nation. Since such an endeavor is never once and for all given it involves much argumentation. 'A sound family makes a sound state' is a phrase that could well summarize aspects of this argumentation. Through Linden echo words reminiscent of Fichte (cf. Kupffer 1984) - the smallest unit carries the burden of the largest, both bound within one order where the individual is central and subordinate. This order, although not a harmonious whole in practice, is held forth as an ideal and a necessity, which the state abuses or benevolently embodies. Within this smallest unit dwells the child, who must come to terms with its own willful nature and dependency, learn that 'life is hard' and sets its price. For the people of Linden, the aim is to make a child lebensfähig ('fit for living') through Erziehung. This is very much an active practice and success is judged by the child's behavior. The right actions of parents and teachers are deemed to invoke the right sense of behavior in a child, and a wish to be good, to obey, to be polite. To be free is to want order.

Wholeness and unity are elusive concepts, difficult to circumscribe, as that of state and nation. They refer to that which is 'imagined' (in the terminology of Anderson 1983) and, in the case of the state, for example, to confrontations with certain structures of dominance and control. The state makes itself known to people through the activities of its institutions and persons, such as the school and its teachers. It sanctions political and economic activities and legitimizes a sense of personal belonging on a national level. As I see it, it is the particular sense of order people adhere to which amplifies their notions about wholeness or unity. Wanting order is also, in a sense, wanting the state and its legitimizing power. And with a certain amount of pride people will point out that today they live in a Rechtsstaat ('state of law'), in contrast to earlier dictatorial or authoritarian forms of state. This state rule is also contrasted indirectly with a general lack of rule. ${ }^{11}$

In Linden a constant oscillation comes to the fore in different situations between the ideas and values of autonomy and uniqueness and the necessity of order and subordination. There is an ongoing attempt at reconciliation, of bridging these Gegensätze ('opposites, contradictions'), 
and keeping intact that which strives apart, even threatens to disrupt. The person, into which the child is being formed, is part of and subordinated to, the social collective as manifested by the family, the school, and the kindergarten. But the person also has a free will and is responsible for his or her actions. There is a sense of minding one's own business which also distinguishes social relations, a preoccupation with boundaries, and the right of the person. Notions about economic freedom obtain special force in this context. Property rights give wide-ranging rights, and it is no one's privilege to question the rights of the owner. The order of the state is ambiguous, for it is seen as protecting this individual freedom, yet also encroaching on it. But as freedom on a more individual and general basis also appears to have a potentially anti-social, disruptive component, it is also considered that 'too much freedom' is detrimental for the social capacity of the child.

It is important, if not easy, to see this in terms of people living an ideology without being this ideology. That is, ideologies are part of the reality which people live. They merge with thinking and practices which shift and change and contradict each other, they cannot only be understood in terms of themselves but in relation to a context of time and space. Turning to Linden, I cannot pretend to give but a fragmented view of this complex of identity and German ideology. My description and analytical attempts concentrate on those main institutions to which children must subordinate themselves, the ideas and practices they there meet and cope with, the values they learn to discern - the whole explicit and implicit spectacle of lebensfähig machen ('making fit for living').

\section{Childhood and pedagogics in German thinking}

Western conceptions of children and their upbringing and education have been a subject of study and divergent interpretations among historians, whereas anthropologists have been more concerned with cross-cultural comparisons of such conceptions. Our contemporary ways of distinguishing children are closely linked to the recent centuries' rising concern with the centrality of the individual, the presumed necessity of forming this individual into a particular social being who is regarded more and more as an autonomous, self-reliant being on which society is dependent.

Ariès (1962), whose analysis of the development of the conception of 
childhood is now a near classic, yet not undisputed by later research (cf. Pollock 1983), sees a presumed development of the nuclear family and a rising interest in education as crucial factors in changing attitudes to children, making them into special beings in need of care and guidance, separating children conceptually from adults, and providing more and more room for specialists in their rearing and education. Forms of control become more diversified and institutionalized (cf. Rutschky 1977). Other historians rather argue that "the invention of childhood as a separate state corresponds with the transition from feudalism to capitalism in the 16th century" (Pollock 1983:31), that is, modes of production are given explanatory status.

Considering notions of children and childhood, one is prompted to focus on the treatment of children, that is, the occurrence of indulgence, discipline, negligence, and so on. Several historians seem to consider that childhood was a more or less miserable state until our own century "most (historians) insist that the majority of children were cruelly treated in the past" (ibid:13; cf. de Mause 1976). Ariès argues that the development of a conception of childhood did not lighten matters; on the contrary, it meant more severe methods of rearing (p.413), but others disagree with this.

Historians have often used child-rearing manuals as a source for their assessment of behavior (Ariès' material also used works of art), not problematizing the link between behavior and values, according to Pollock (ibid.:43-46), or the fact that most parents do not usually read such manuals and if they do, will not uncritically follow the advice given. Nonetheless, written documents discussing, describing or advizing are part of a cultural discourse, so that even though such manuals do not directly correlate with actual behavior, they may influence ideas and actions as well as be influenced by them. What is possible to say and think and write in one period may not be so in another. It would be illogical to presume that commonalities in these manuals would not have some grounding in a cultural logic also at the level of actual parental activities.

For my purposes, the point is to consider a few ideological markers in this flow of pedagogical or social-philosophical literature (which is not only, of course, a German matter but a general Western one). It is not an attempt to write about the history of education and child-rearing, but to find certain leads as to how one can view the Lindeners' concern with education and upbringing. ${ }^{12}$ Through centuries, the preoccupation with 
learning and achievement and notions about praise and punishment have become central for conceptions about upbringing and education in the formation of the person. The body has turned out to be a powerful arena on which these ideas may be implemented. The people of Linden are no less confronted with these sets of problems and ambitions

During the 18th century, upbringing and education became a key question in the ideological, practical-philosophical debate. As Elias (1939/ 1982) attempts to show, the molding of behavior into forms of 'good manners' and the changes of social and personality structures which he sees as connected with this, is a long process which does not have a given beginning. Confining oneself to the more explicitly modern period of the Western world, when the individual came to be more and more of a central issue, it need not be unduly simplistic to refer to Rousseau as a point of departure. His work has in one way or another been influential on our thinking about ourselves as individuals and social beings. For German social philosophers, such as Herder and Fichte, as well as educators like Fröbel, Rousseau's ideas about the social nature of man found appeal, the idea that one cannot become human outside society. This also applies to his notion about the relation between freedom and control, a sense of freedom being the outcome of minute control of the context in which the child moves. ${ }^{13}$ Rousseau pondered over what Man and society are, but more importantly, in this context, he was preoccupied with how this Man is made, formed, how Man can become a citizen. This preoccupation he shared with several of his contemporaries, and the solution was not only education but up-bringing, the conscious forming of the person, who becomes morally responsible for his or her actions, yet answerable to a higher order. This person is also tuned in to his or her own interests, which meant notions about a child's capacity and its developmental stages (see Ambjörnsson's Introduction, 1977, to Rousseau's Émile). And this preoccupation with the developmental stages of the child has been of great concern among all kinds of educators and in pedagogical research ever since. One need only consider the influence of Piaget in our own times. ${ }^{14}$ German pedagogical history is not just one of patriarchal or authoritarian ideology and methods, or imbued by romantic notions of 'self-cultivation' and individual inwardness (or today marked by pluralism and democracy), however one may be prone to think along these lines. For all their seeming divergence, such German pedagogical thinkers and practi- 
tioners as Friedrich Fröbel and Moritz Schreber, from the first half of the nineteenth century, have continuously combined concern about the state of the German people, of being German, with education and upbringing. There is then some overlapping among the various directions of pedagogical thought, even the 'anti-authoritarian' movement of the 1970s clings to the notion of the centrality of pedagogics for the making of the person.

A few overarching themes appear in the works of German pedagogues in the 19th and the 20th century - the family, the state, the people, and nature. And the problem is how human beings relate to and are formed by these entities. It is the relation between the individual and the 'whole' which is at stake, and it is only through education and upbringing, Erziehung, that the essentials of this relation can be brought about.

Fröbel was a student and colleague of the Swiss pedagogue Pestalozzi, who was close to Rousseau's thinking. Pestalozzi has had an immense influence on pedagogics not only in the German-speaking world. Fröbel is most widely known for his foundation of the kindergarten (see Allen 1986, H.Fröbel and Pfaehler 1982; cf. Hendry 1986), which grew out of his concern with a 'total education' and the importance of the early phases of childhood. Fröbel combines in his work the idea of the benevolent, encompassing, continuous education and upbringing as a life-process, education as the creator of the human being, and a more state-oriented upbringing, the forming of the good citizen, a Volkserziehung ('national education/upbringing').

This latter strongly engaged the social philosopher Fichte, who saw the need to raise the spiritual level of the people, something which could only be attained through upbringing and education in the hands of the state. Since parents are demoralized by the times they are living in, Fichte thought it necessary that the state take over the education and upbringing of children. Fröbel, on his part, found the family, and particularly the mother, to be the essential element in the forming of the child. The family, not the state, is the true educator, and his founding of a kindergarten and his development of toys and songs and advice were meant to also inform and form the educating mother. But Fröbel meant, as Fichte did, that the times were bad, that evil reigned in Selbstsucht und Selbstigkeit ('egoism') (Fichte 1914), which can only be overcome by this encompassing education. But Fröbel did not strive for the upbringing of 'state machines', as he felt Fichte was doing, instead he wanted education to create free, 
reflecting persons.

This argument, about the family in relationship to the state (or 'society'), has been going on until today in Germany. To what extent does the family have rights over the upbringing of the child? To what extent should, and does, the state take over these rights? This has also led to debates about the problems of a strong family orientation, that individuals become societally disinterested and politically passive, meaning politically illiberal or conservative, a view held by Dahrendorf (1969), and it also appears in some general works on the political and social system of the Federal Republic, for example in Claessens et al. (1978), Sontheimer (1989).

For Fröbel, upbringing means that the individual should not be educated for his or her own sake but for the sake of the Gemeinschaft, for the treue Hingabe des Einzelnen an das Ganze zum Bestehen des Ganzen ('the loyal/faithful devotion of the individual to the whole; for the maintenance of the whole' (in Fröbel and Pfaehler 1982:126). And Fröbel's educative concern is that of all humanity, not just the German people although the German people are the bearers of the highest level of humanity: ...in den Eigenschaften des deutschen Charakters sind die Eigenschaften der höheren Menschheit ausgesprochen ('in the traits of the German character are the traits of a higher humanity pronounced') (ibid.). With this Herder would not disagree, however much he was a proclaimed cultural relativist, for his point of departure and return was always the German people (see Barnard in Herder 1969, and Dumont's analysis, 1986a). The concern of Herder and his contemporaries, was the formation of the individual in relation to 'a whole', "the history of mankind is necessarily a relational 'whole', a chain formed from the first link to the last by the moulding process of socialisation and tradition" (Herder 1969:40).

Herder was a critic of the bureaucratic state of his times and its system of control, in this way differing from the late Fichte (cf. Bramsted 1972, Krieger 1957). But both were concerned with the necessary Bildung in order to link the people's cultural heritage from one generation to another, and at least for Fichte, come to terms with the Selbstsucht ('egoism') which was destroying the possibilties of a German nationalism. In partaking in this Nationalerziehung, as Fichte spoke of it in 1806/07 (1914), no individual should be hindered in this striving towards a higher order because of being of lower social class. The notion was an education of the whole people, to instill a will to learn, and a love of what is good and right 
(Fichte, ibid.). Today the recurring theme of educational reform is that of Chancengleichheit ('equal opportunity') (cf. von Dohnanyi 1971, Baumert et al. 1984).

The person is part of a whole, but for this whole and the person to persist, the consciousness of identity, collective and personal, must be instilled through forms of education. Such were the terms, and I would say, however differently phrased and felt today, such are still part of the terms underlying the pedagogical concerns of post-war Germany. There was no simple agreement between the various pedagogues and social philosophers, as to how this education should be shaped or as to the true nature of the child's capacity. Should education be prescriptive or should it be permissive? Should it lead the child or let it 'grow on its own'?

Fröbel, like others intellectually close to him, held to a Pädagogik des Wachsenlassens ('a pedagogic of free growth'), following Rousseau's 'negative eduacation' (cf. Cleverley and Phillips 1986), that is, an education whose task it is to keep away those negative influences which threaten to disturb or destroy the child's spiritual and bodily growth, its true, or natural, nature - the 'authentic life'. ${ }^{15}$

Others, such as the well-known German pedagogue of the 19th century, Herbart (cf. ibid., Rutschky 1977), were also concerned with the inner growth of the child and its potential for the good of the collective, but he is considered to stand for a Drill- und Lernschule, a more hard-core education tuned in to the acquisition of prescribed knowledge and achievements (cf. H.Fröbel 1982, Kupffer 1984). ${ }^{16}$

But in whichever direction they may have leaned, Fröbel or Fichte or Herbart, their seeming differences are slighter than one may at first assume (which is a point also made in Kupffer, ibid.) - they are all concerned with the necessary and active formation of the child for the good of society, for the unity of the German people, defensively hoarding the essential and common identity after the last vestiges of the Holy Roman Empire of the German Nation had given way and the many states appeared problematically fragmented.

The body emerges here in the interstices between their differences, if one may put it that way, and becomes the controllable mediator between spirit, nature, and society, a means through which the individual may be immersed into the body of the people. Life close to nature, the body through work and play and gymnastics pflegen ('tend, care, groom') and 
abhärten ('temper, make hardy'), so as to cleanse the spirit, was part of Fröbel's educative aim. This is, in one way or another, a part of most German pedagogical ideology (as it is in most Western educative programs, I would suggest). Bodily movements and bodily care are made into specifically important aspects of education. Strength and health are meant to be attained through a controlled and harmonious use of the body as morally good nature. It has seen its extremes - the particular minute control of bodily movements prescribed by Schreber through his several writings on the subject as a physician and a pedagogue, and his recommended contraptions for good posture while sitting and walking; straps to keep the child from lying on its side while sleeping; and the crusade of bodily discipline, euphoria, and brutality during Nazism (see Bleuel 1976, Lithman 1988, Koonz 1988, Brückner 1987, Mosse 1985).

The body became more and more of a moral and scientific concern in education and upbringing during the industrializing nineteenth century. Körperliche Erziehung ('physical/bodily education') was a means by which the mind could be controlled and the body made acceptable and efficient. The 'discourse of the body' was one of discipline (Foucault 1979). The body was to do duty both for the nation and for the individual person's growth - gymnastics as a pedagogical instrument, sports as a patriotic force. The Turnvater ('father of gymnastics') Jahn was an eager and radical nationalist at the beginning of the 19th century. The number of Turn-associations in Germany grew and physical education became part of school education.

Educational devices reproduce ways of conceptualizing the person and relations of power through a manipulation of the body and its image. Our kind of knowledge is inseparable from this process, and according to Foucault, it is always the body which is at issue, "the body and its forces, their utility and their docility, their distribution and their submission" $(1979: 25){ }^{17}$ It is in our times a 'docile body' which is manipulated and made known so as to control what is 'inside' it. The changes in the uses of the body are related to the social and political world within which persons move. The means and extension of power change as its forms of legitimation change and this sets its marks on the body and so becomes a source of knowledge of itself and of the structure of power. The body is not primarily an arena of sensations but in the modern era becomes more of an intermediary between an inner and a social world, and so 
important to control.

Schreber was a fervent advocate of physical education as a means of creating harmony between body and spirit. Defects and incorrect growth and the dangerously incomplete nature of the child could be remedied through a sound and healthy life (Schreber 1845, cf. Rutschky 1977). For Schreber the body was strongly linked with morality, and the body appeared more in its individuality than before. Each individual child is in its development subjected to an array of risks and dangers which can lead it astray, away from its naturalness (Lithman 1988, cf. Schatzmann 1973). In order to protect the child from such dangers adults must keep a close watch over it, particularly its various bodily expressions and ailments, to "protect the biographical individual from its own vices and unnatural drives" (Lithman ibid.:39).

The body and the person in the body became a moral garden to be tended and the real garden a place where such moral work was concretized. The so-called Schrebergarten was meant to be the means for the working classes to realize such goals, and to this day 'Schreber gardens' are found in and around urban areas. They are small plots of garden land where families may grow vegetables, fruits and flowers. They are not devoid of recreational value, but this can only be realized if the moral and educative impetus of cultivation, of beauty and harmony, is accomplished.

Turning to Linden, one finds a concern with the moral and natural body which is reminiscent of the problems posed by these nineteenth century thinkers, even if this is making too great a leap. The body is groomed and trained and displayed, a control through which the independent and orderly person is made possible. The body is incomplete as it is and this is particularly so with the young child. This incompleteness is an antithesis to the natural order of the body and that of the social world. All of this the child attains knowledge about through others' manipulation of its body, either directly or through forms of discipline and reward. The child is then an ambiguous social being, unnatural for not being orderly, as 'order is the nature of nature' and so must be tended, as the gardener tends the garden, with love and care and a relentless eye for weeds. But since the child is also a store of much natural energy which must be let out, the too wellbehaved child is not considered quite normal, that is natural, it may be ill, or it may be too harshly treated. So there is an oscillation between what is seen as natural order and natural disorder. 
Ordering the body is not only a matter of daily routines and a kind of developmental control, such as learning to distinguish on one's own between the clean and the unclean, it also means a variety of corrective measures which are mobilized. The young children will have their tonsils extracted, or more commonly the adenoids. Little boys are often found to have foreskin constrictions and are operated on. Backs are crooked and must be straightened through exercise therapy or the use of corsets. Teeth and bite are corrected through braces. Speech may be faulty and must be corrected through expert training. There is an array of institutions which thereby make themselves felt - hospitals, special kindergartens and schools. As for adults, they will mainly consider themselves as suffering from Kreislaufstörungen ('circulatory disorders') and feel they must at least once in their life get to a Kurort ('health, treatment, resort') and have their cells revitalized.

In a kind of counter-position to the forms of control, the body is at times used as a joke, a spectacle of fun and obscenity. Apart from mutual joking and teasing among friends and opponents, Fasching, the carneval before Lent, is the prime public event for staging the hilarious or burlesque spectacle.

Both the fearfulness and the absurdity of the controlling agent and the controlled body are aptly depicted in the two well-known children's books, Der Struwwelpeter and Max und Moritz, which are found in almost every home in Linden, and in Germany I would guess. They are much read and greatly enjoyed. Der Struwwelpeter, 'the world-famous Frankfurter' as the figure is called when used in advertisements, was written in 1845 by Heinrich Hoffmann. He was a physician in Frankfurt and father of a small boy for whom he found no good book which was both fun and educational, so he decided to write one himself. It became a national success with the unkept, unruly, disobedient figure of Struwwelpeter and his companions Paulinchen who naughtily plays with matches and is burned to death, Konrad the thumb-sucker whose thumbs are cut off by the tailor for his disobedience and dishonesty (secretly sucking), and all the others whose bodies are attacked in different ways to control misdemeanors. Disobedience is (unnatural) disorder and leaves its marks on the body, which becomes disorganized, dismembered or quite frankly extinguished. Imagined sensations of the body are used to establish a kind of inner control of the child's behavior and emotions. In a similar book, Max und Moritz, written by 
Wilhelm Busch (1865), the children (two naughty boys) make an uproar, harming and teasing the agents of control - but finally being outsmarted and transformed into unknowing, but orderly, nature, seeds for the geese to eat, gutes Fressen (good feed), to the miller's satisfaction.

These stories would hardly have been written today, some of the meanings and values they evoke may have changed, but they have not become meaningless for they work through emotions and memories of imaginations. On the other hand, the manuals of Dr. Schreber on bodily and spiritual health and naturalness and the various wooden and leather contraptions he envisaged to correct bad posture and other bad corporeal habits in children have become as such obsolete (if they ever were extensivley used), but concern about bodily order, good posture, good health, in relation to a sound soul is not. In various ways it has been incorporated into the education of children through generations.

\section{Bringing up and educating - notions about Erziehung}

Ausbildung des Geistes und Körpers des Menschen, eine gründliche, für die Verschiedene Zwecke des Menschenlebens genügende Ausbildung des Geistes und Körpers des Menschen: Lehre, Unterricht, mit einem Wort - Erziehung ist es also was der Mensch bedarf. ('Education of the human spirit and body, a thorough and adequate education of the spirit and body of the human being for the various aims of human life: learning, teaching, in one word - Erziehung is what Man needs'). Friedrich Fröbel, An unser deutsches Volk, 1820/1965).

What is Erziehung to people of Linden? It is a necessity. No child can grow up into ein richtiger Mensch ('a real human') without Erziehung. It is not enough to just live in a family together and hope that all will go well, that the child will become a good person. It is not that people think of the little child as evil by nature, but neither is it good. People will rather tend to speak in terms of the child being undifferentiated and weak and so easily influenced by that which is bad. This is reminiscent of the common German garden-analogy used in relation to the growing child and the parental task of raising it. The child is the frail plant and the parent the gardener, keeping weeds from encroaching on it, and letting in sunlight (cf. Métraux 1970a, Allen 1986) so that it will grow strong and sturdy. This 
is not just a privilege of being adult, but a duty. Erziehung is also necessary to ward off bad influences from within the child, not just from without.

That which is considered to be within has to do with Veranlagungen and Charakter, that is, biological disposition, or the child's own nature. Veranlagung is used as a kind of modernization of the nature-concept, it is a more scientific term, making nature perhaps appear more comprehensible as it refers to ideas about biology or genetics. There are several traits which are referred to biology, but there is no complete consensus as to which traits, only to the notion of Veranlagung as such and the limits it may set on educational endeavors. It is a reservoir to use when behavior or moods or accomplishments in a child seem inexplicable. It need not only refer to negatively valued traits. Intelligence, for example, is highly valued, and is thought of as innate, but without upbringing this trait or capacity will dwindle. Great intelligence may diminish the relevance of other thought traits. That which is 'without' is also a matter of who is defining the child or the situation. Generally it has to do with television, the weather, bad friends, Überforderung (over-demandingness) - the school demanding too much, or the parents, or society at large, depending on who is talking. This without is difficult to do anything about, but only Erziehung can be a buffer against such outer influential powers.

The environment, die Umwelt, as a whole is referred to for its troublesome influence on children and weak parents. In newspapers and discussions among teachers, at certain church meetings, also among worried parents, children are proclaimed to be much more aggressive today than before. They are over-stimulated through television, there is too much violence and delinquency in society, and religious sects lure youngsters into God knows what (see for example the views of Meves 1987). Many parents cannot make their children obey. They cannot say no to their children, many teachers will assume. Parents are also blamed for not caring about their children, only taking an interest in their own work and careers, spending too little time with their children. Parents themselves may blame the school for demanding too much of the children. A teacher, Herr Bender, was heard to report on the disastrous situation which he had some contact with in the town where he is teacher (and where many of the older Linden children go to school) - the high suicide rate among teenagers due to parental demands for achievement by their children. In other words, a kind of crisis would off and on be proclaimed - juvenile delinquency, 
violence, drugs, terrorism - there is something wrong with how society is being run, and there is something wrong with how children and youth are being brought up.

The following quotation, Das deutsche Volk befindet sich in einer chronischen Notlage, der durch Erziehung abgeholfen werden kann ('The German people/nation feels itself to be in a chronically distressive situation, which can only be alleviated through education and upbringing' Kupffer 1984:73), summarizes according to the author a fundamental view of German educational ideology. He sees it as transcending political divisions of 'left' and 'right', blurring some of the declared differences between the freiheitliche, flexible ('free and flexible') movements in accordance with Dilthey and other more repressive and rigid movements (the 'Herbart school') of childrearing (op.cit.:81). The raising of children must have a goal, setting the child in relation to a social and cultural whole. It is nothing haphazard, not part of a program of personal whims. It is through Erziehung that the good can stand up against evil, that the person can become free and responsible. Erziehung tends to be taken, then, as a major remedy for the ills of society and of the nation. Erziehung is considered a means to construct the good, stable society, perhaps even the means, which suggests that conflicts and upheavals in society may be explained by reference to 'bad upbringing' or lack of upbringing. This emphasis on Erziehung, which has as its main ideological focus the family, links notions of the person to the workings of the state. It is some of the details of this linkage that I attempt to elaborate in this study.

The people of Linden were in the 70s part of the nation-wide discourse on Erziehung which comprised 'anti-authoritarianism' on the one hand, and its counter-force on the other, a kind of moral rearmament coining the phrase Mut zum Erziehen (the courage to raise/educate) (cf. Fishman and Martin 1987). Often in discussions among Lindeners someone will refer to the fact that 'Germany is the most child antagonistic (Kinderfeindlich) of all countries'. What is implied among the Linden people is, for example, the high rate of children killed in traffic and the meager economic support given families. In the literature child abuse and social inequality are also taken as examples (cf. Bleuel 1971, Rutschky 1977). Many school and church meetings and seminars were held on the subject of Erziehung, and people were on the whole deeply involved with the raising and education of their children, which was also a common everyday 
topic of conversation, particularly among the women and the teachers. But the flood of books and articles in newspapers and professional magazines is not what people usually refer to, it is not what they tend to read. Monthly magazines such as Eltern ('Parents'), published in Munich, are of interest to some who enjoy the 'modern and open' approach to the raising of children. Some find good advice in the local parish Sunday Bulletin, others look through the magazine Schule \& Wir ('School and us'), which school children receive free of charge every other month to take home to their parents. But most views and advice are given and received by talking with one's close kin and with good friends and neighbors, and attending local meetings on the subject.

There may then be many intense debates and educational experiments in society at large, but people live through their own experiences, and will interpret information in relation to this. In other words, there may at times be an impression through mass media that there are great changes going on, that now everybody thinks or does this or that. There are also many parents of young children who consider they are rearing quite differently from their own upbringing, particularly in relation to the degree of severity used. But this may be more a belief in change than change itself, and such valuation of change has to do with the idea that people freely choose their lives from a variety of alternatives, which then also are interpreted as being quite different from each other, and quite different from a before, and so better, when, in fact, perhaps they are not.

This concentration of upbringing and education as a kind of Katastrophenabwehr ('averting catastrophe') (Kupffer 1984) is not something new, as we have seen, it rests on a long tradition in the history of German upbringing. Kupffer refers to nineteenth and particularly twentieth century educational literature, which tends to recommend Abhärtung ('hardening, tempering') so that the hardships of life can be mastered, and takes Fichte as an example, having all the essential elements of such a catastropheoriented pedagogy. The ills of the nation, or the state, are explained by the failings of its educators, a view to which both left- and right-wing ideologues subscribe, now as then, however differently. Throughout these two centuries then, Erziehung and the Erzieher, in particular the expert Erzieher, the professional, are seen as the means by which the Germans as a people and the German state can manage and overcome political conflicts or catastrophes, the harshness of life, and the failings of being human. 
It is only through Erziehung that one can become human, which means that bringing up and educating is thought of as an essential humanistic activity.

\section{Punishing and praising}

An essential aspect of Erziehung is the use of punishments and praise to attain wanted results or deter unwanted behavior. It may be common among us to expect punishment, quite generally, to be an essential part of most children's experience of the adult world, and I think it is common among Swedes, for example, to consider Germans as particularly given to punishing their children. Punishment is not an unambiguous conception and its position in child-rearing practices and ideologies varies over time, between cultures as between individuals. All adults exert some form of control over their children, but the extent to which they will explicitly attempt to regulate their children's behavior and thoughts differs in relation to an ideological and social context. The people of Linden, as parents and teachers, are preoccupied with their necessary influence over their children, and from that standpoint punishments also become a necessity, die Strafe muss sein (there must be punishments).

Without punishment there will most likely be no Ordnung. But punishments should not be meaningless, that is, from which a child is assumed not to learn anything. It must learn what it has done wrong, and what kind of behavior is expected of him or her. It is considered meaningless to write the same sentence 25 or 100 times for having disturbed or been disobedient in school. Instead an extra piece of homework is adequate, or having to do some arithmatic instead of hearing a story in class. Such punishments are seen to stand in a meaningful relationship to misbehavior, and are thought to make the child aware of this. This is the pedagogical punishment, combining learning with disciplinary sanction, and it stands in close connection with similar forms of praise.

Punishments are more in the nature of being planned, one should not punish in blind anger. To slap the face, or even spank, is not really to punish - dass der Hand ausrutscht (a euphemism for boxing ears) happens to everyone. Real beatings are less common and are not considered in terms of punishment, but rather talked about as severity, being too severe. To beat a child more or less regularly is a sign of one's own weakness and 
inability as an adult. Practically every adult will remember having received a real beating at least once, and it is always talked of as having been deserved, but parents who are known to beat their children continuously have transgressed the boundaries of responsible parents. Punishments are meant to do duty for the maintenance of order, children must learn to take the consequences of their actions. If they have misbehaved at home, or in school, in kindergarten, they must learn to accept their due punishment. A child who is frech ('sassy') can count on being slapped or more in the order of punishments, be sent to his or her room, forbidden to take part in something he or she is set on doing, kept inside. ${ }^{18}$ To be frech is emphatically unacceptable and every child knows it. The child takes liberties in relation to adults, denies their superior position.

But lying is perhaps the worst of all. There is nothing which parents dislike more, and which perhaps also worries them the most should they discover such immoral behavior in their child. Métraux (1970a) quotes child care literature and its use of gardening metaphors for the raising of children, also mentioning there the necessity of "preparing the ground on which later the love of truth can grow" (ibid:212). ${ }^{19}$ Lying implies that the child is not willing to take the consequences of its actions, making, in principle, someone else carry the burden of responsibility or guilt, Schuld. To grow up imagining that that is a possible way of dealing with reality must be curtailed, making lying into a punishable act.

Praise, or rewards are not so very different in structure from punishments, at least not in a pedagogical perspective. Although I do not consider praise extensively here, this does not imply that it is unimportant, but it is often less distinct. Adults will in many situations give the child positive recognition through various gestures, but this is not necessarily goal-oriented. Through more pedagogically oriented praise it is assumed that one may achieve particular results with the child - it will do well in school, it will obey, it will be happy and reward the love shown it. Teachers are keen on admonishing parents to praise constructively while helping their children with homework, while parents, and adults in general, are more oriented towards the giving of material rewards, such as sweets, rather than verbal praise. Or they will joke, and with a small child perhaps carry it around for a while. But the sweets are central, and in Linden a child is seldom seen in the company of adults without receiving some form of sweets. It is like a wordless mediator between adults and children, between order and disorder, if you will. 


\section{Order and independence}

There are several concepts and ideas which combine to express the meaning of Erziehung, and people will place their emphasises in various ways, but not so that they become mutually incompatible. There is always a common store of explanations, references, which attempts to make life workable and tolerable. Through some of these 'key conceptions' I shall attempt to elucidate their ideas.

Das Schlechte nehmen die Kinder schneller an wie das Gute und ich glaube da ist das Vorbild der Eltern schon wichtig.

('Children are quicker to take after that which is bad than that which is good, therefore I think it is important with the parents as models'.)

Ich kann denen vordemonstrieren wie ich lebe und ob sie das dann einmal auch machen wollen, das muss man denen überlassen.

('I can show them (the children) how I live and if they later on also want to do it this way they must decide that for themselves'.)

(Quoted from an interview with a young father of three school children.)

Linden parents will at times point out that they are a model for their children. Attitudes to this vary, some find it more important than others, being more conscientious about it, but on the whole, parents are their children's models. At times lends their actions and their thoughts a weight beyond the immediate perception of them. It means that parents will have to control their own thoughts and actions, perhaps do things they would rather not, all for the educational cause.

The main point in the notion of Vorbild lies in that Erziehung is a striving to 'make something' out of a child and this endeavor rests on ideas and values about what a person should be, which the parent, or teacher, should embody. Parents should do what is right, show a child by their own actions how to act in different situations - but this showing is usually not considered to be enough. A child must be told how things are to be, that it has done well or badly, parents must be consistent, not make a child think that at one time one can say no to something and the next time yes. That leads a child to think it can get its way as soon as it wishes and is demanding. It just makes for confusion and the child will not learn what 
is right.

Teachers will often be heard saying, when talking about parents in general or about a particular family, that parents are not consistent, 'no' is too easily turned into 'yes' and the child will never learn that it cannot always have its way. Certain families are considered by most others to be bad examples for their children - there is no order, too much drinking, too many children, unemployment, fighting and just plain dumbness.

Women, more than men, will try to organize their lives in accordance with the axiom of being a good example for their children, although men will be more prone to seeing themselves as their children's model. Perhaps since men are physically, or emotionally, more absent from the children than women, they may be more concerned about this aspect of being a model. Many motivate their weekly attendance at Sunday Mass in terms of Vorbild, that is, that children must go to church, and if they see that none of the parents go then they will not want to go themselves.

As long as a child is under the care and supervision of its parents it must do what is expected of it, but when the child is grown up he or she must decide for him- or herself what is right, how life should be lived, 'each lives his life as he sees fit'. Some parents avoid any discussions which would allude to any religious doubts within the hearing of their children. This would hazard the children's view of how things are and should be. It would make the child uncertain, perhaps even bockig ('stubborn, unruly') and disrespectful. But when they are adults, then they must do as they wish, parents will say, 'as long as you're my child, in my care, it is I who decide and you do as I say. It is my duty to do what is right and it is your duty to do what I do', as one mother formulated it.

Quite often people will say something like this when talking about their children and their future lives. Also when speaking generally about other people's doings, comments are along the line of 'each must do as he pleases, I live my life, others live theirs, I can't bother about what other people do or think'. This is on a general level, not really connected with any particular individual, or in that case only superficially, as an avoidance of being pulled into gossip. But people often enough refer to what others will say or think if they or their children do not follow that which is taken as rules of conduct. Yet people are of the opinion that they themselves always do as they please, not caring what others may think. They do not let themselves be pushed into doing things they do not like; for example, 
one lives in the house of parents or parents-in-law if one gets along, not because anyone tells you to.

This idea of the free will, a freedom of choice is linked to the problem of Schuld, as I see it. A person is responsible for his or her actions. A child will often hear when complaining about something that has happened, a fight maybe, or the teacher having been angry in school, that 'it was your own fault, you can't be blaming others for what happens to you' - $d u$ bist selbst dran Schuld ('it's your own fault'). Selbst dran Schuld is a very common phrase in Linden.

Adults are not usually excused by referring to circumstances in their childhood, what the parents did. Whatever they do cannot be blamed on the parents, the Erziehung. You alone are responsible for your actions, albeit with some modifications, since people are aware that there is a past, that the past stands in some kind of relation to the present. But the question is, what kind of relation is it assumed to be? What in the past has relevance for the present?

When it comes to the people of Linden, it all depends; that is, the situation, the context, the persons involved, are decisive for what the relation is thought to be. The question of Veranlagung is never really left out, whether in positive, negative or neutral terms, but neither is it always of primary importance. Often all left-overs, actions and assumed traits which seem otherwise inexplicable, will be understood in terms of Veranlagung. Or else influences from the outside world, 'bad company', for example, may be invoked to explain why a young man has ended up in prison, or why a few women are alcoholics. Some men are known to have mistreated their wives and families, and a few of these women have committed suicide. Some mothers are known to be, or to have been, very harsh with their children. A few families seem to wallow in debris around their houses and on the whole seem to be pretty much 'down and out', and there is one or other 'hot-head' and political trouble-maker. Others have been very succesful, have a good business, children who do well in school, or quite simply have a decent job, a nice house and a family which is in Ordnung (orderly). Now, all this may to some extent be understood in terms of what kind of family the person comes from, but the family, that is the Erziehung, cannot be made responsible for the conditions of the present adult.

Certain factors, particularly intelligence, are mainly seen as a result of biology, so for the unintelligent child one refers to the family - 'what 
can you expect, they're not very bright any of them', referring to other siblings (this is a comment made primarily by kindergarten and school teachers). But notions of heredity are not continuously made relevant. Once adult status has been reached, intelligence or unintelligence is a trait of one's own making.

People may consider that parents are, or remember them as having been, too harsh with their children. This may perhaps make for an unhappy person, but does not really explain any eventual lack of success in life. However, there is one thing in the Erziehung which may be referred to as explaining behavior in adult life and that is when parents are assumed to have been too nachgiebig ('lenient', literally giving way), spoiling the child, letting it have its way too much, not seeing to it that it learn the right way to behave. In this way, the German terrorists of the BaaderMeinhof group, or the RAF (Rote Armée Fraktion), were assumed to have developed this violent, anti-state, anti-social behavior through a lack of Erziehung. The parents have not been a Vorbild for their children, they have not attempted to teach them what is right and good. This does not imply that it is the parents of these terrorists who should be to blame in the sense that they should take responsibility for the terrorist actions. However, it does imply that the state will be undermined if families are not 'sound' and do not bring up their children properly.

Another trait or capacity besides Ordnung, Ordnungsliebe ('love of order') which is highly valued in children is that of Selbständigkeit ('independence', literally 'stand on one's own or by oneself'). ${ }^{20}$ Parents want their children to be selbständig, independent. Teachers, both in school and in kindergarten, encourage them to be selbständig, and they all consider that they should try to make the child selbständig. Selbständigkeit is then dependent on the Erziehung. It is not quite clear, though, what it is in the Erziehung which makes a child selbständig, and parents will sometimes worry about this, finding their child either verwöhnt (spoiled), which is often used as the opposite of being independent, or just not independent, perhaps even using the term anxious. Among the kindergarten teachers a spoiled child is one who always tries to get his or her way and who does not know how to take care of his or her belongings and does not actively participate in the different activities. This resembles the school teachers' views, although they may lay more stress on taking care of one's things and doing homework well and the tasks given during the lessons. 
The child who is selbständig does things on its own, gets dressed in the morning without asking mother which clothes to put on, does the homework without having to be told, puts things back in their place without asking where they belong or having to be told to do so. It manages on its own, does ñot cling to the mother for support and indulgence. Concretely, stress lies on learning the given order of things, being neat and tidy and orderly of one's own accord. This connects the concept closely with ideas about Ordnung, so that the two are not separate and opposite, but intertwined.

Everything that is done should be done in orderly fashion, for when everything is done so the person is in order, that is, 'outer' order stands in direct relation to 'inner' order (within the person). It is scarcely conceivable that inner order can be surrounded by outer disorder - which is not contradicted by what could seem to be disorder, the 'wild places' I speak of below. Order in this context stands for keeping house, garden and body, and car neat and tidy, well-kept and clean. Things should be put away in their right places.

But nothing is ever quite as it should be; however much a mother erzieht zur Ordnung she may find it does not help. As one mother says, she hates to have to look for things, she always puts everything back where it belongs and she wants her son to do the same. She keeps telling him, showing him, how to keep his things in order but it does not help, not even seeing how his father keeps his tools in perfect order makes him change. I guess it's partly angeboren (genetically inherited), she says, trying to comprehend the failure to get wanted results when direct admonishments, reprimands and acting vorbildlich (as model) do not help.

Only children, or children who have siblings much older than themselves (which is not uncommon), are usually considered to be in danger of becoming spoiled, or are practically defined as such, at least by kindergarten teachers, since they usually are unwilling to participate in the different activities in the beginning of their kindergarten period. 'They're just used to having everything their own way'. Some parents who have only one child may go so far to solve the problem of lack of Selbständigkeit that they send the child to boarding school. Of course, this is not common, most people cannot even afford it. At least they would rather spend their money on something else, but this does not make it less interesting that such an alternative is used to accomplish that which one's own Erziehung has not. 
There are parents who see Selbständigkeit somewhat differently, although the question of being orderly on one's own accord is always present, if not so explicitly stated. But they will also stress the importance for a child to 'stand up for his or her own opinions, being able to listen to others and discuss with them'. This also includes the freedom to choose school and occupation, even if it should not quite accord with the wishes of the parents. In this case, then, Selbständigkeit has more explicitly to do with ideas about the free will and may resemble more the ideas of modern intellectuals. The cultural logic within which ideas about children, upbringing, and the person develop is equivocal enough to allow for alternatives. The people of Linden, whether middle class or working class, share a great many experiences and ideas. Living, as they do, however, in a social world where, on the one hand, boundaries are maintained quite strictly and where, on the other, ideas about the rights and responsibilities of the individual are prevalent, the field is open for variations and idiosyncracies. Everyone agrees with the modern axiom of no two individuals being alike and that each has a right to his or her opinions and choices. Part of growing up and becoming a person in this social world is to find out the meaning of free choice, or freedom. 'My freedom ends where the next one's begins', is a concise and agreed statement, the meaning of which must take a life-time to discover.

The adherence to Ordnung is ambiguous, there is an unmistakable admiration of 'wildness' - the energy and romping around, the fun and fighting among children, and the boisterousness, obscenity and festivities, even recklessness, of the adults. One should learn to love and cherish order, the child should want to be obedient, to understand the wishes of the parents. As their saying goes, Ordnung ist das halbe Leben ('order is half of life'), encompassing the other, the 'wild places'.

Germans are known to themselves and to non-Germans as being very orderly, some seeing it as an obsession. German intellectuals, mainly of the 'left', so often angered and exasperated by 'Germanness' and the German state, deride this constant preoccupation with Ordnung and its derivative, core some would say, of cleanliness. They are also at a loss as to what to do with it, what it is, since it reaches into every nook and crany of ordinary life, also their own, I would imagine.

It is my impression that order and freedom often seem to be considered together as a pair in German ideas about society and about their 
history (cf. for example, Dumont 1986a, Krieger 1957, Lukes 1979, Rodnick 1948) and Linden notions of Ordnung and Selbständigket are always linked explicitly or implicitly, and include their sense of freedom. Such links may seem contradictory, that the demand for order rather negates freedom, but I think that the valuation of Ordnung is in fact a valuation of 'wholeness', 'unity', that Ordnung is another term for das Ganze ('the whole') which preoccupied Fröbel so much. And it is only within this order, this whole, that freedom appears to be attainable and so comprehensible. Unity, wholeness, is something 'imagined', analogous with Anderson's use of the term in his analysis of nationalism, the nation as an "imagined political community" (1983), also emotionally appealing and powerful. It cannot be made concrete other than through the ordering of a myriad of details in daily life and an array of notions about the right and moral life and the good and just state. It spills over from one institution or situation to another, being readjusted along the way, picked up in inter-personal relations and even used as a part of one's knowledge about oneself. These concretions never accomplish any ultimate Ordnung, unity/wholeness, and so they must constantly be thought about, repeated, reconstructed. ${ }^{21}$

\section{The necessity to learn: notions about lernen}

One could summarize the conceptions about independence and order, and even the more encompassing notion of Erziehung, under the heading of learning, with the risk of over-simplification which summarizing probably always entails. ${ }^{22}$ Being a model for one's children is an indirect but very controlled means of showing, or teaching them the right way to act and think. It implies that the child must learn to be orderly and independent, it must learn the essentials of life.

Learning is a way of relating to the world, viewing life as a matter of learning. Life is not just lived, life is more of a project than that. It is only through learning that the world, and the person, is made. It is through conscious and controllable action that the world becomes meaningful and manageable.

Bildung is perhaps the concept which is mainly associated with German notions of education and Kultur, denoting the striving for 'self-cultivation' and intellectual and emotional refinement (see Bramsted 1972, Bruford 1975, Dumont 1986a, Elias 1982). It is then not synonomous with lernen, 
yet they may intermingle and in their daily discourse people in Linden do not usually make any particular distinctions. They speak in terms of lernen, parents and teachers think of their children, and of themselves for that matter, as learning or having learnt. Here it is not a question of being gebildet. Bildung is a term reserved for learned others, such persons one does not know oneself. Notions of self-cultivation, of being 'intellectual', are not a vital part of Linden life, however much they may be a part of a German historical image. Lernen is more concretized, it goes from an outer ordering to an inner order, whereas Bildung orders from within the person who strives for this inner sense of wholeness. I think one could say that learning defines a social hierarchy, whereas Bildung attempts to deny it.

In Linden learning is a kind of guarantee that children will abandon their uncontrollable ways and become dependable and orderly, which is being natural. There is little to indicate that people hold the view that life itself can function as a school, that is, that children learn just by living in a social entity. Such a stance would be taking too great a risk, it is too haphazard and has too unforeseeable results. Very little good can come out of such learning, only bad habits are learned in uncontrolled situations. If children are to learn from what others do, they must at some point in an event be made conscious of its didactic worth, otherwise they may not detect it. At least this is how parents and teachers tend to valuate upbringing even if they do not always act in this way. Actions which are imbued with such values are made 'visible'. Children become trained in certain skills, and are quite accomplished performers at times, going shopping for their mothers, helping out with other chores, playing musical instruments, reciting at school entertainments, in church, and so on.

The idea is that children must learn, not that children have any particular urge of their own to learn. They must learn in order to become proper adults who know what is right, who will be hard-working and lead a decent family life. To achieve this it is necessary that children are kept close to the adult world under superveillance - firmly led over the pitfalls of childhood. This would fit with the common gardening metaphor for child rearing, and it seems still rooted in the world of kindergarten and school.

What seems to be the case is that experience as such, one's own experience, is not so highly valued. So-called anti-authoritarian life styles 
may be accused of appealing to spontaneous reactions and associations, which is then seen as disorderliness or as some also say, laissez faire-ness. It is rather the trained, or 'schooled' experience which is the more valued experience. This comes to the fore especially in discussions at school meetings, but also in other kinds of less formal gatherings. It is this which is mainly considered to be knowledge.

It is more through imitation than reflection, that a child is thought to learn best. This influences the contexts in which learning is meant to take place. The idea of imitation, Nachahmung, may seem to contradict the idea about learning. Yet what this aspect of learning implies is, in extension, that adults function as models for behavior, as Vorbild, and that adults - parents, teachers - must act correctly. They must also explain to the children why things turn out as they do, why a certain punishment is administered, or a reward given. Children are rarely thought of in these contexts as being able to discriminate between the meaning of the same act performed in different situations, or to be able to grapple with inconsistency and contradiction. There also seems to be a view that a certain behavior will generate exactly the same behavior in the child, a kind of one-to-one correlation. This idea about Vorbild may for many parents, and teachers, feel burdensome. Their acts are thought of as constantly being controlled, as if they are being watched and judged. So even the idea of Nachahmung, which in itself is a preordained process in children, demands measures of control and restriction, because anything can be imitated, especially that which should not be. Teachers, as well as parents, may blame bad, unwanted behavior on this capacity for imitation. Then it is imitation of someone else, some 'other' - bad children, irresponsible parents, or some neutral, non-controllable outer force such as television. This gives some alleviation from the finding of fault in oneself or the situation one is a part of (which is much less common). Children are influenced by all kinds of happenings, and many are feared to be bad and so must be kept at bay. Others are not as easily controlled, and neither is life itself. The idea of imitation as a way of learning is not so far removed from the more explicit concepts of learning, and teaching.

The concept of learning is both valuative and a way of relating to the world. As a valuative concept learning becomes a norm to be followed; it is not something to be questioned, learning is morally right. The question is only what should be learnt - and so taught. In this sense learning 
requires authoritative persons or institutions who teach what others should learn. It is to these institutions and persons I shall turn in the following chapters, referring back to and amplifying the concepts and notions of Erziehung that I have presented here. But first a detour over Linden life and work. 


\section{The place and people of Linden: a setting}

Linden, schönes, altes Dorf im Wald! ('beautiful old village in the forest'). The people of Linden are, most of them, proud of their Heimat. They like to praise the beauty of the region and the friendly complacency of rural life, much as more sceptical intellectuals or sophisticated city-dwellers of Frankfurt disdainfully look upon the village as ein Kaff, ('a hole'). As an outsider one is often requested to express a positive opinion about the village and its surroundings. Looking through some of the local yearbooks I found this instructive verse:

Wer die Heimat nicht liebt und die Heimat nicht ehrt, ist ein Lump und des Glücks' in der Heimat nicht wert! ${ }^{1}$

The geographical-ecological room to which Linden belongs is the valley of one of the tributaries of the river Main. The Rosenthal, as this valley is called here, stretches into wooded lands, a widespread region of forests and hilly country on both sides of the Hesse-Bavarian border. The area with its high ridges, sloping hills and small streams is then partly forest covered agricultural land where orchards and even some vineyards intersperse the meadows. It has mainly been a region of small-scale farming and about one-third of all the land in the region was still being used for agriculture in the 70 s. 
It is truly a lovely landscape, formed and cultivated for centuries. Walking along the wide paths in the woods where beech trees tower overhead, or gazing out over the fields from a hill-top and seeing clusters of houses of nearby villages, it does not seem difficult to imagine how traders, soldiers, bandits, serfs, abbots and priests, travelled along the old trade routes; roamed the countryside; soldiers attacking villages. The Thirty Years War, the Napoleonic wars, the times of feudalism and monastic rule - this seems nearer at hand than the world wars of our own times. There is no place here for tanks and machine guns, or SS-men. Nowadays, all one meets are people out on a Sunday walk, wandern, some in the wellknown knickers and sturdy walking boots one has learned that Germans wear and which a few actually do wear (see Weber-Kellermann 1978).

Coming along the road over the high, wide ridge 30-40 kilometers south of Linden, the landscape opens up below and spreads out into the far-off horizon. The distant silhouette of the old city of Aschaffenburg is woven into the thin blue-grey haze of the continental sky. The endlessly unfolding perspective is like that of Renaissance paintings. As the lushness. and serenity of the countryside may lead one to loose sight of 'the world', so was it difficult to connect the relative complacency of Linden life with the fierceness of Germany's political and social conditions. Much of the strain of doing fieldwork lay in this elusive contradiction.

Linden has a population of about 1200 . Together with two smaller villages, Kleinheim and Waldhof, each with a population of about 3-400, Linden constitutes a church parish, Pfarrgemeinde. Until the mid 70s Linden comprised its own political/administrative municipality, as did the other villages. It has lost some of its locally autonomous position, being more incorporated into state (Land) administration. Though Linden has kept its mayor and a council, elected for a period of six years, the greater administrative burden and privilege has been moved to a larger village, or town, Brücken, which now is the administrative center of the whole upper valley. During the 70s there was an overall municipal re-organization of Bavarian local communities, enlarging the districts of local authority, which had lasted for a hundred years. Linden is now administratively part of one of the most densely populated municipal districts (Landkreis) of Bavaria.

Although the people of Linden find it important to emphasize their Bavarian status (the area was incorporated with Bavaria in 1816) it is still Hesse which in many respects is of more immediate importance for them. 
It is in Hesse, namely in the Hanau-Frankfurt industries, that many of the men find work; it is to the larger villages and nearby towns in Hesse that many go to do their more extensive shopping; it is in Hesse many find a spouse; it is often there many small children spend a bad time lying in hospital; and it is even there some children are sent to secondary school. This is a bit contemptible since it is considered that the Bavarian school system is much better and more demanding than the Hessian. In this contempt lies also the different political situations of Hesse and Bavaria, the 'red' SPD (German Social Democratic Party) Hesse and the 'black' CSU (Christian-Social Union) Bavaria, which prevailed at the time. ${ }^{2}$ The towns and villages in the immediate surroundings are bracketed from this view.

Three roads lead into the village, meeting at the main junction, dangerous as it is, as in many other villages. The traffic is often quite heavy, cars are driven full speed, the corner is turned with screeching brakes. People tell me about others who have been killed at a cross-roads just like this. These roads, connecting the Hessian with the Bavarian, wind their way through village after village, lying 1-2 kilometers apart, out to the Autobahn and the greater cities. Here and there roads have recently been repaired. The gigantic military tanks ruined roads and fields on the latest NATO maneuver, held the preview season in the Linden area. The American soldiers came marching through the village, rhythmically calling and singing, stopping at the bakers to buy bread, giving the assembled children Juicy Fruit chewing-gum, 'just like old times' (Bavaria was an American zone after the war).

Bachstrasse, the old cobble-stone street which runs through the heart of the village, is lined with small shops - the bakery, the grocery stores, a post office, bank, hair-dresser. They occupy the ground floor of two or three-apartment houses. By the parking lot in front of the neglected fencedin garden belonging to the church, where the poplar trees tower, stands die heilige Elisabeth, the village patron. The greyish-white statue of Elisabeth, with her humble gaze and oddly large head tilted, stands in a small fountain. The water is dirty and the fountain is full of cigarette butts, leaves, and chewing gum. On the sidewalk are empty soda cans and candy wrappings. Children ride their bicycles around in circles on the mainly empty lot. It is full of cars only on Saturdays and Sundays for Mass. Boys and girls sit on the low fence, talking and watching, especially on warm summer 
afternoons.

The unornamented red-brick church, built during the 18th century, lies at the other end of the garden, next to the newly renovated Pfarrhaus, the priest's house, where the priest lives together with his housekeeper. Next to the spacious Pfarrhaus lies the small town hall, which houses a library, a large assembly room, the mayor's dark and somewhat cluttered office, and a smaller conference room. For many years the school house was also to be found along this square, but the school has been moved outside the village core. The local authorities are gathered in the village center, and even if their range of power is diminsihing, their influence on local affairs should not be ignored.

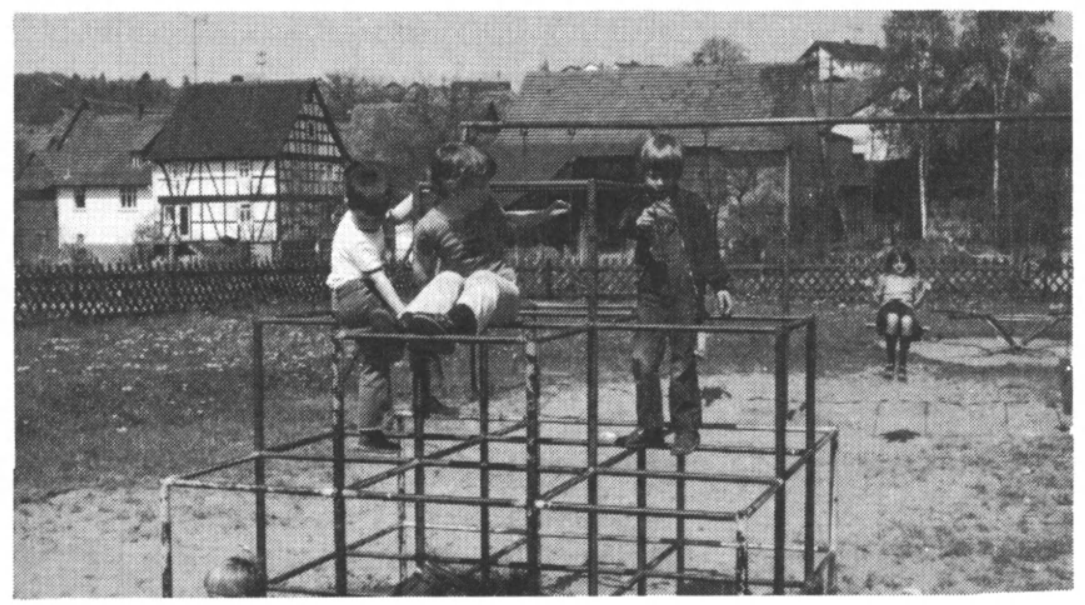

The Gemeinde playground, near the center of Linden

Houses lie close to each other, the oldest in the middle of the village, many half-timbered. Some still keep cows in their barns, or have pigs and hens. Often a dog will stand im Hof ('in the yard'), barking and growling as you pass by in the street. Outside this core, up on the slopes, are the newer houses, many appearing quite expensive. Usually houses have two apartments, downstairs live husband and wife and their unmarried children, upstairs a married son or daughter and their children. Some people 
prefer to rent the upstairs apartment to an unrelated family. A few people from Frankfurt have moved to Linden.

Linden in late afternoon - the stores are open, the streets full of people coming home from work, youngsters running errands, the bus is soon to leave, some men stop at the inn. A short while of bustling crowdedness gives an atmosphere of the older quarters of a working class part of a town.

\section{Land and work, aspects of class and belonging}

One impression from the ongoings of daily life, the chores, and the ways of associating between people, is that there are no great differences as far as social position and economic assets are concerned. Linden, like the other villages in the region, is fairly well-off on the whole. The greatest differences seem at first to be between old and new parts of the village, as between old and young persons. This is not an unreasonable view of Linden but it is much too limited.

Until recently, studies of German rural history tended to stress the homogeneity and continuity of village life among farmers, the 'traditionalism, humbleness, and wisdom' of 'the peasants' (Farr 1986). ${ }^{3}$ This has in later years become more and more criticized, giving way to more complex studies within Volkskunde and social history (Evans and Lee 1986, Hausen 1984, Ilien and Jeggle 1978, Kaschuba 1986, Sabean 1984). ${ }^{4}$

Linden is, of course, no country idyll and in several respects it is not even particularly rural, although land, house and inheritance are significant aspects of life, as they were to a greater extent, or in a different way, for earlier generations. The economic and political structure of Linden is not the focus of my study, and will therefore only receive limited attention. But since work, income, and 'position' form and are formed by the world in which people live, how they see themselves in relation to others, the ambitions and hopes they set on their children, they cannot be ignored.

The people of Linden have not relied solely on the land for their income for many generations. They have been employed in industries since the second half of the 19th century - the men as factory workers, the women as home-workers or in local enterprises; later some women began to find work in the larger towns. But even today, most Linden households have some land at their disposal, though very few have enough to support 
themselves. Those few who have larger farms rent most of their land, which has been a common practice. Through the rules of equal inheritance, Realteilung, common in southern Germany since Napoleonic times (cf. Catt 1986), land has been partitioned for each generation. This form of inheritance differs from that of northern Germany, where land has been held intact, inherited by a youngest or oldest son, economic compensation going to the other siblings. The tendency in Linden has been for the oldest son to stay with the farm, either leasing or buying the land from his siblings, 'but now it's the one who has the most interest' is the opinion heard. A woman who has a farm is considered to have more difficulty in finding a husband than a man has of finding a wife, since most farm work is now defined as male work, implying that few wish to take this up if they are not already farmers.

During the 60 s there was a total re-location of the land, Flurbereinigung, a state reform which took several years to implement. At the time, at least, this gave rise to 'many evil words' - people felt that they had received worse land than they had had before; that their orchards were diminished; that the committee which had been chosen to represent them to government officials had used this position for personal benefit. Some parts, the present housing area, were exempted from the re-location. The fields there were redefined as building plots, which meant that those who happened to have their land there suddenly were lucky owners of one or more building plots which could be sold or built on.

Before the re-location many had become Feierabendbauern ('leisuretime farmers'), but this was too strenuous and they tended to lease their land more and more. The re-location made tractors possible to use and 'practically everyone bought his own tractor', farming now seemed easier and economically more attractive - 'everyone wants to be on his own, there's no tradition here of reciprocal aid among farmers', one of the expanding farmers complained. Still, the trend in the region is fewer and larger farms with increasingly one-sided production, concentrating on fodder for the raising of milch-cows and swine.

Almost every household has a kitchen garden, either by their own house or a plot somewhere else, since the gardens were also re-located. Up by the cemetery the land is very fertile and about fifty gardens are located there. One often sees the women, who primarily care for these gardens, bending over their vegetables and spice- and flower-beds. So, 
having some land to cultivate has been an essential part of life, but not the only or even the main source of income for several generations.

Today Linden and many of the neighboring villages are characterized by a proliferation of small industries, often family enterprises with few or no employees. The Schnapps and apple wine distilleries cater to the needs of those with fruit trees, and also sell apple wine to Frankfurt. The region has traditionally contributed to this beloved Apfelwoi ('apple wine') of the Frankfurters. The small firms in Linden, and similar ones in other villages, employ mainly young girls and married women. There is in Linden only one small firm which employs almost only men, and several men work a year or two there as young boys. They manufacture metal-ware for handbags and suitcases. It was through this firm that the largest leatherware firm in Linden, the Lewa, came to be established there some years earlier, in the beginning of the 70s. The owners knew each other and coordinated their production.

Leatherware products dominate the women's labor market in Linden, although not so before the war. The three or four firms have women working both in the factory and at home. The Lewa has about 25 women working on the premisses and about 110 women employed as home-workers. The others function on a much smaller scale, but they all are dependent on the large leatherware industries in the Offenbach area (in the vicinity of Frankfurt), whose subentrepreneurs they are. The firms in Linden produce handbags, purses and suitcases. Other firms in the region employ women in Linden as home-workers without having local Linden agents.

Home-work is largely performed by women, and has for some time engaged many women of the region. In Linden it goes back to the $1860 \mathrm{~s}$ when crocheting began on a small scale, engaging many households by the 1880 s. It was for a long time the dominant source of wage-income for young girls and married women, especially in Linden. During the slack agricultural season mothers and their daughters would sit all day in the living-room at their crochet-work (Wolff 1905). Production was solely based on home-workers, who were loosely contracted through local agents, whereas the fabrication of cigars, dominant in the lower valley region, soon came to be located in local factories, and did not engage Linden women to any great extent (ibid).

A third major source of home-work was tailoring, which had its center 
around Aschaffenburg where a clothes industry began to develop in the 1870s, being Germany's largest textile/clothes manufacturer at the turn of the century (Wörner 1956). Production was concentrated on men's wear and it depended on small contracted tailor firms spread out in the region. These home-workers were men, very few women worked as tailors. When production expanded, women dominated by far as unskilled workers in the factories set up in Aschaffenburg, and this has been the case up until today.

The oldest family firm in Linden today started with crochet work and I was shown some of the creations they still had lying in boxes from those days when the modern women of Berlin and Frankfurt wore embroidered decorations of flowers and butterflies on their dresses and coats. This firm now has ladies' hats as its speciality, still relying on home-workers, such as Frau Kestling.

Frau Kestling has been sewing hats for the Feder firm for thirty years, her mother also worked for this firm. She is so used to it, she says, that she couldn't think of just taking care of the household and have nothing else to do. Many women in Linden would agree; they do not just want to take care of the household. To have an income of her own every month is of course very important. She is paid per hat, not per hour or day. She works about 8-9 hours a day and manages to sew about 12-15 hats in that time. She earns about 5-600 DM per month. She thought the Feders pay less than other firms, but her married daughter who works for the Lewa half-day does not have much more per hour than she manages to get.

This daughter lives with her husband and two children upstairs in her parents' house. Frau Kestling does the cooking for the midday meal and she and her daughter and granddaughters eat together. They would probably earn a little more if she did not work for Feders at all and took care of the children instead while her daughter worked full time. But she thinks that would be too strenuous, especially having the responsibility for the children's homework. In her opinion, everyone should bring up their own children, an Oma shouldn't do everything, then you get the blame if things don't turn out so well with the children, the Oma is too lenient, nachgiebig, they will say'. 


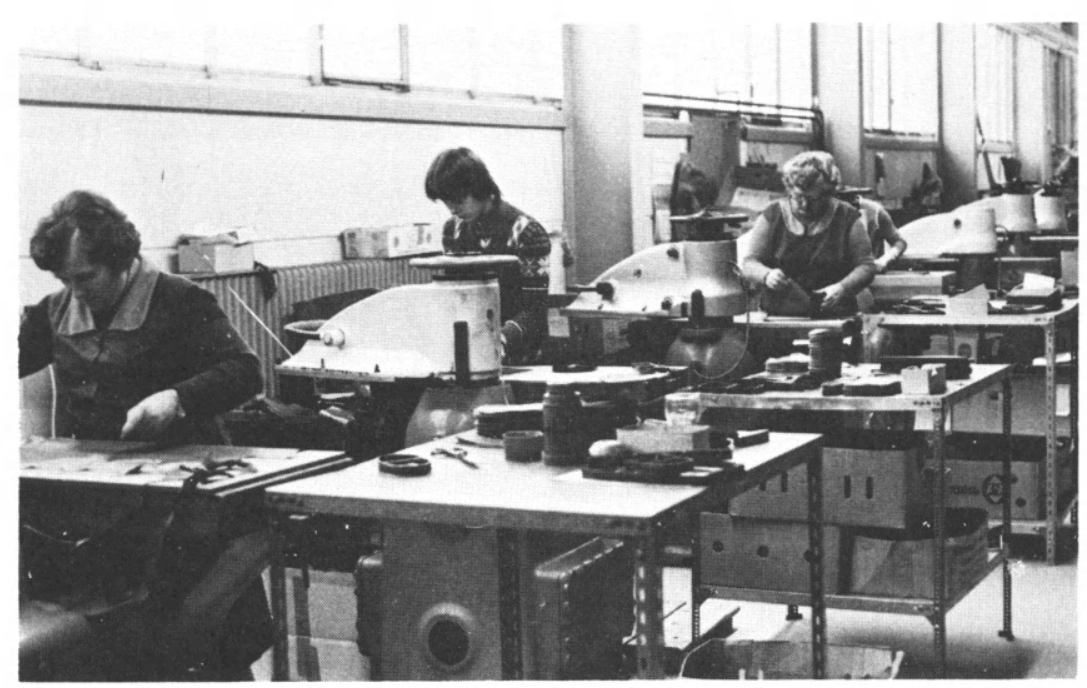

Women working in a local leatherware firm.

Those who are employed in the village or in similar types of small industry elsewhere, mainly women, are considered to be underpaid, something they are aware of. Membership in trade unions is not seen as a means of changing this. The women will grumble, sometimes dare ask indirectly for a raise, rival with better paid work-mates, but they are afraid of losing their work if they were to organize. They want to work close to home, have the children and the household under control. The reputation of a good mother and housewife who does not let wage work come first is important to keep up, as is the image of the good, dependable husband/ father who is able to sustain his family.

The employers do not see any point in the workers organizing - as the wife of the Lewa owner exclaimed 'whatever would women do in a trade union!?' Although it is very common for women to have wage-work, the attitude is as if they did not have it, which means that engaging in trade unions is a direct recognition of something which is rather to be played down. There is a trade union for home-workers, Frau Kestling tells me, and sometimes a representative has come home to her and asked if she has any questions or complaints, but Herr Feder is always present so there isn't much she can say. She laughs a bit ironically and shrugs her shoulders. 
The union does not try to convince her to join either, she says, and 'anyway, there wouldn't be any point, there isn't really anything to change, it works well enough as it is'. She can talk to Herr Feder if she wants something, at least more easily than talking with Frau Feder. Her husband works in a glass smelting industry in Hanau and is member of a trade union, which is not problematic as it is for her. The men usually find work in the heavier industries or the larger firms further away and are not caught up as much in the petty exploitation of the small local firms.

The railway, built in 1898, now replaced by buses and cars, connected the many villages of the valley with each other and with larger towns in the area, thereby facilitating the increase and spread of home-work production and the possibility to travel longer distances for work. For the men, work outside farming has almost always meant travelling to larger industrial towns, and the whole area is characterized by this commuting, which resembles descriptions of other areas (cf. Ilien and Jeggle 1978, Spindler 1973).

Everyone does not, of course, work in industry. There are also Angestellte, people who 'have employment', that is, white-collar workers. Some of these are women working in offices in local firms, banks, post-offices, with the Gemeinde, the municipal office. A few are Beamte, civil servants, with their special obligations of state loyalty and their privileges of security and pensions. A prominent category of the Beamte in Linden is the school teachers.

There is, then, a variety of ways of earning an income. As a side-line to regular income from employment, many are engaged in some kind of production or services, or even secondary employment, being owners, or part-owners of the means of production. When one adds up all the extra incomes, the small cultivated plots (owned or leased), the building plots inherited or bought, the houses being built, the patterns of exchange of work and commodities, and forms of aid when building, it all seems to even out between them. But people are not of the same class, neither do they belong to Linden in exactly the same way, even if there is this impression of sameness. The differences between social and economic categories that people perceive as important do not necessarily adhere only to scale and form of ownership, but have to do with education, kind of employment, and with the size and kind of farm the family/kin had in the past, that is, to what extent the person or family is an old one in 
Linden, in other words, how native one is. Most of the people have a Hauptschule education, which is the lower secondary school, some with additional years of vocational school. Fewer have a higher school education, and Gymnasium, the highest secondary school, is fairly uncommon.

People are aware that certain professionals, such as the teacher, the doctor or dentist, and the priest, have a high status (although traditionally Catholic priests do not come from upper classes, see Sagarra 1977) and they agree to respect this, but that does not mean that they are the most highly esteemed as far as intra-village relations go. The point is that local and official estimations both intersect and collide. People are sensitive to the status of others in relation to themselves - der Herr Pfarrer, der Herr Lehrer, die Frau Rektorin, der Bürgermeister ('the priest, the teacher, the school principal, the mayor' - although the mayor is of a different category, usually being native to Linden); the well-to-do firm-owner, the successful architect, the local delegate for CSU, etc. - all these categories or persons are shown more formal respect, and so distance, than the 'ordinary' worker/ employee, who also is one's regular neighbor.

All these people who are employed in industry and offices, the small firm-owners and shop-owners, they have their house, their garden, perhaps some milch-cows or pigs. The wife may have home-work, the husband working outside Linden. They do not seem to classify themselves as of any real difference of status, even though the office-clerk may feel herself to be better or brighter than the woman working for Lewa sewing handbags, yet associating closely with another woman working for a similar firm doing just about the same thing as the Lewa worker for the same pay.

My general assumption is that even though there are variations and seeming differences between categories of people and they are engaged in the intricacies of classifying status positions and so marking differences, there are ways and views which supersede social and economic differences. These bridge diverging or antagonistic political opinions, so that a sense of coherence and 'sameness' is established, or at least imagined. The ideological and practical project of raising children and so striving to form the person and the good order of things is an essential part of this common point of reference. 


\section{Ways of associating}

Not only do people constantly engage themselves in some kind of work and household activity, there is also something going on in the village most of the time. People are members of different voluntary associations, Vereine - music, sports, gardening, pigeon-raising, the fire corps; there are choirs; youth groups; and to the church belong local groups of nationwide organisations. ${ }^{5}$ Off and on seminars and other types of meetings are arranged where fundamental problems are discussed, such as religion and the church today, child-rearing, family life, terrorism, the death penalty. In addition, numerous feasts are arranged in every season, sometimes drawn out over days. Fasching, the carneval before Lent, is perhaps the most spectacular, at least the most commented on. The church arranges meetings and processions and is also the frame for many of the more secular feasts. Kindergarten arranges a variety of events, not only for the concerned families, but for everyone who wishes to come to the Christmas bazaar or the summer feast. The brass band plays on many of these occasions, day and night, in church, outside of church, everywhere.

The bounded public events as forms of associating are in some ways easier to get access to for an outsider trying to participate than the more secluded and individual forms of associating between small groups of friends and close kin. The voluntary associations make room for varieties of links which only partially come to the fore in smaller private groupings. People do not just go home to each other uninvited unless they are mother and daughter or sisters. It does not do to seem idle and curious. The home is a secluded area where dirt is one's own business. Men are even less apt to go home to each other in this way, they do not go home to a brother or a father and just have a chat and a cup of coffee. The mother may be someone for a man to visit, but his wife is more likely to do this in his place.

Instead, people arrange all kinds of reasons to associate (also to avoid associating). Families celebrate birthdays, visit for Christmas. Married couples join together for Saturday evening bowling and then perhaps have a bite to eat together at a Wirtschaft ('inn, pub'); a 'clique' of younger, married women meets once a week in the home to sew or play cards and gossip and once in a while go out for a pizza together; some couples meet on a summer Sunday afternoon for an outing to barbecue. They do things together, and at least when both men and women are together the conver- 
sation is often of a joking, reminiscing kind, sometimes burlesque and obscene.

To a large extent associating is family-based, even at large village feasts married couples and their close kin tend to stay together. In most 'cliques' of friends there are at least a few who are siblings or in-laws. People stick to those they usually associate with. Gender, age, and class are significant aspects of associating but do not form closed and separate categories, they rather qualify each other. Although people are keenly aware of social distinctions, of bounding and separating, careful not to 'meddle in others' affairs' and risk becoming responsible ('get the blame') for someone else's mistakes or bad fortune, which does influence how one's network of association develops, it does not make boundaries unnegotiable. The specific context of any association will influence how the distinctions between people are noticed and used. In relation to outsiders, Fremde or Zugezogene ('strangers' or 'newcomers/in-movers' - people not born in Linden or related to a Lindener), such distinctions are more easily adhered to, since such persons are not Lindeners, and often are 'people of a certain position' - priest, doctor, teacher. Among Lindeners in the ongoing village life, employer may be good friends and associate with a not so well-paid employee. As noted above, several factors modify the force of class. Life-styles may be quite similar - owning and caring for a house; having building-plots and gardens; having children to raise and see through school; going to church; participating in the voluntary associations.

Kinship relations are a way of handling the whole problem of class differences and the extent to which they 'make a difference'. Associating primarily with the family and close kin marks the ranks without any explicit comment as to class or personal preference. Class is a less avoidable problem when it is combined with differences of access to political power. Just being well-off, with a good business, some land, need not make a difference if the person does not have political ambitions, using education or economic assets as a means to manipulate contacts and make a political career.

The many public events, feasts and ceremonies, sometimes make people grumble. They protest that it is too much work, takes too much of their time, but in the end they will usually participate and do their share of the preparations. Some refuse to partake in any such events, being 
satisfied with their own doings and their family. Certain families and individuals move on the outskirts of what is socially acceptable behavior, drinking too much alcohol, fighting too much at home, being promiscuous, living in misery and squalor. They are not ostracized, but neither do they participate much in the general public events. Individual Lindeners may condemn them, but one does not have the right to make them one's own business if they do not bother you. In this way they are tolerated, with some indignation and anger, but also with jokes and sometimes a sense of compassion. Going to the inn after a meeting to have a glas of wine or a beer means that one may end up spending time talking with persons one would never dream of associating with privately.

Married women tend to associate through the home in a way men do not, as mentioned above. Men without women will rather meet in public places, which women may also do, but their base is the house. Women will not go regularly to the inn, which men may do, although younger women, also those who are married, do go out together once in a while. A brief illustration gives some glimpses of the more house-oriented associating.

There are some differences between the Kaffeekrantz ('coffee gathering/circle') Hermine Walzick arranges off and on when her mean and stingy husband is away at work and the Tuesday evenings at Christiane Mahler.

Hermine Walzick is a heavy woman in her fifties. She is a Lindener of old, whereas her husband is a war refugee from the East. Her two sons are away most of the time, one studies in Hannover, the other is doing his military service. She is very proud of her sons, but does not give much for her husband. Until some years ago, she worked for one of the small leatherware firms but after a long sick-leave she was told that they did not have enough orders to take her back. She felt they cheated her, just wanting to get rid of her. She has not had work since then; instead she spends a lot of time and energy on her garden.

To Hermine Walzick's Kaffeekrantz come 'Brandy-Emma', as she was called behind her back in Linden, and Frau Lohr, an elderly lady from Frankfurt who has lived in Linden for many years. Conversation is dependent on how drunk or sober Emma happens to be, how many problems she has with her daughters who try to stop her 'boy-friend' from visiting her. Frau Lohr has travelled some in Europe and likes to talk about her experiences, and Hermine consoles Emma or is exasperated and lectures 
her. As we sit there, we can hear the German Shepherd barking fiercely im Hof, as someone passes by on the street.

Christiane Mahler lives up the street from the Walzicks. She is a young woman, not yet thirty, who lives with her husband and two small children in his parents' house. The parents own a Metzgerei, a butchery, and he is butcher and works there with them. Christiane's parents and siblings live some streets away. She works half day in a small local office at terribly low pay, as a sister-in-law says, but she just cannot stand the thought of having to cook for them all every day, which she would have to do were she at home, so rather bad pay.

Every Tuesday evening her husband's sister, her cousin and the kindergarten teacher, Heike, who is still unmarried, come to her place and they either sew or play cards or watch television, drink coffee or wine. Usually her cousin's husband also comes along, "he never wants to let his wife out of his sight'. They find it a bit odd but accept it, and the two of them seem to get along well. Once in a while they all go out together to a town nearby in Hesse and have pizza. Christiane's husband joins them most of the time when he comes home a little later after his football training with the schoolboys. He seldom stays and has beer at the club house inn. Since he likes to tie rugs, which some men do, he will sit down with them, or just watch television.

\section{Municipality and local politics}

Social and economic position, and gender, are significant factors for the development of political activities and the establishing of a political career, which, of course, is not unique for Linden. Politics is men's business, as one woman said. On the labor market and in political life women as a category are not held in such high esteem and they seldom attain influential positions in local politics. Someone else voiced a fairly common notion among Lindeners, that politics only means strife between political parties, so does not really concern one's daily life. The recent municipal reform reminds them, again, that this is not the case.

The valley has been divided into three administrative areas, each with its political/administrative center, which means that a municipality like Linden has lost yet more of its political autonomy. Linden has kept its council and mayor and some administrative rights and economic re- 
sources, but the main local political and economic power has been moved to Brücken. Antagonism between villages has come to the fore, Waldhof has chosen to align with Brücken rather than with Linden, to which it belongs ecclesiastically, thereby weakening Linden's political position, causing much Ärger ('annoyance, ill-feeling'). There is antagonistic joking about the 'silly folk' of Brücken and the opportunism and intrigue-making of the Waldhofers. Actually, it was much worse in Brücken before the war, according to an elderly council member, 'because of the Jews living in Brücken'. They were business people, as Jews always seem to be according to many Lindeners and their neighbors, and they caused much gossip and suspiciousness and many conflicts. 'Now they're not there anymore' (since the pogrom of 1938, when the synagogue was also burnt down). 'But there are foreigners there now and Zugezogene from Frankfurt. They keep to themselves, they don't belong. There's no Gemeinschaft in Brücken, as there is in Linden'.

Through marriage alliances, one could say, economic and political resources have been amassed for some families or sets of kin and made it possible for certain members to dominate the political arena. Mayors have tended to come from the same households or sets of kin, for example. This is no sociological surprise, it has also been documented in other studies (cf. Catt 1986, Kaschuba 1986).

It is then above all men who have access to political power and make political careers. It is through their public fora, the inns, and now also the sports association's club house, that the politically active can make themselves heard and control information. Women do not go to the Wirtschaft regularly as the men always have been able to do. They do not have the same kinds of public meeting-place just waiting for them to attend and which are in the same way undisturbed yet open for 'interesting' guests. Women are publicly active, working, participating at meetings and feasts, being members of associations, and not least reproducing the family. They are influential, but politically they tend to back-up their men-folk rather than replace them.

There are a few powerful springboards into Linden politics - the church, of old standing, and the voluntary associations, in particular the Sportverein, which is also seen as a rival of the church and its organizations. Several of the council members are also members of the church board and/or the board of the Sportverein. They are tied together as in- 
dividuals and as organizations through economic interests which lead in and out of Linden, making the CSU party into a stable and powerful resource for its active supporters. This is not officially acknowledged but known in varying detail, and for some seen as an obstacle to getting people to elect a new mayor instead of the 'stubborn old buzzard' they have had for many years. 'It's the person one votes for, not the party', which means that as long as the mayor is a candidate it will cause much Ärger if someone is nominated against him, since there are no effective party lists. The CSU receives by far the most votes in general state elections, and in practice also in Linden local elections since most of the council candidates are CSU. A few of them are SPD but seem to feel that this is no reason for particular conflicts with the other members. Generally, people seem to find it commendable that in local elections 'party does not matter', they go to the basics, the person and who he is.

Franz Josef Strauss himself was not the most popular attraction of the CSU as far as many Lindeners were concerned. His intelligence was always praised, as intelligence always is in Linden, but he was considered to be too crude and too right-wing. It is difficult to say what makes people vote for the CSU or the SPD, it is not easy for them to make distinctions. Not unimportantly, voting is continuing a 'tradition', it is showing loyalty to one's family. Like one woman who votes for SPD, she cannot imagine herself voting for the CSU even though her husband is a CSU-voter. Her grandfather started the local SPD organization (which subsequently died out, but was showing signs of being re-established at the end of my stay), her parents voted SPD. Her husband comes from a CDU-family in Hesse and many of his relatives are active members of the CDU. That he is an unskilled worker does not make him feel that the SPD is a solution. It seems as if many hold to the idea that SPD people are not really mainly workers but academics and the like, and so often disliked. They can have many arguments, but she is not against various council members because they happen to support the CSU if they strive to see to the best interests of Linden. Most people feel that the CSU upholds Christian values, which the SPD does not, and the church is certainly not blind to this potential. At Sunday Mass a few weeks before state elections, the priest, in his sermon, admonishes the congregation to beware and to vote for those who maintain 'our Christian values'. Everyone understands that he means the CSU and many, both SPD and CSU voters, are indignant - 'politics does 
not belong in church!'; 'it is none of the Pfarrer's business!'

People adhere to a kind of small-scale economic individual freedom, whether worker, Angestellter, or self-employed - one has the right to do as one pleases with that which one owns, one has the right to prosper without others making it any of their business. One votes as one chooses. Since most people in Linden have access to land, however little, and a house, and often have economic interests going on the side of regular employment, this will influence their view of state policy, which is ambivalent. The state demands one's loyalty, that is necessary, but the state should not run one's life.

\section{History, the past, and problems of identity}

I do not take the Linden people that I encountered as exponents of a given history, but as people relating to a history which is also their own construction of it. This then becomes a complex analytical and methodological problem, which in truth I am only able to deal with quite superficially. ${ }^{6}$ If Lindeners are preoccupied with their history and the troubles of being German, then they have this in common with most other Germans. However much people may be concerned with their local history they know that they are mainly understood by others in relation to a global German history.

In 1969, the largest associations, the music, sports and garden Verei$n e$, organized in June a three-day feast to celebrate the 700th anniversary of Linden, Fränkische Heimat, wie bist du so schön!' ('Heimat in Franken, how beautiful you are!'). Actually, Linden is older than 700 years, we are told in the Festschrift written for the occasion. The area was already populated in the late Stone Age and the Bronze Age, but of this we have little knowledge. Much later, the Roman Empire spread northward but did not incorporate the valley, it is noted, but it is assumed that there was contact over the border between the Romans and the freien Germanen unserer Heimat ('the free Teutons of our Heimat'). In the 5th-6th century the Alemannen inhabiting this region were conquered by the Franken (the Merovingian King Chlodwig), and from this period it is supposed that one can trace the name of the village. Linden was then most likely a military outpost close to the forest and the old important trade route which runs east-west. By the 12th-13th century most villages in the valley were estab- 
lished and it is from this period, namely 1269 , that the oldest written document is found confirming the existence of Linden. That year Linden together with Kleinheim and Waldhof was sold by the Archbischop of Mainz to the monastery of Seligenstadt. The three Gemeinden constituted the Herrschaft Linden and were for more than five hundred years dealt with as a political unity. Until the late 18th century the valley and Linden were then mainly under monastic rule, although there were recurring attempts by nobility to gain control over land and people. In line with the Napoleonic political order and the spreading secularization, most villages of the region came under the authority of the Fürstentum Aschaffenburg. The Rosenthal first went to Hesse, but by 1816 was incorporated with Das Freie Königreich Bayern (Fächer 1968).

Such historical facts as presented in the Festschrift appeal to a sense of belonging to an age-old community, being immersed in the 'dramas of history', being part of a collective process. The excitement of its particularity is told in the tales of the adventures of bandits and villains who rode in the forests along the old trade route. Many people are concerned with their history, of which this ancient trade route seems to embody much of what makes Linden particular in their eyes and at the same time part of greater processes. Out walking with people, I was often shown the stone marking the old border between Prussia and Bavaria, a marker of difference that no longer makes such a great difference. But they were still pleased to be on the 'right side' of the border when there is a border, although they may feel culturally closer to the region around the Hessian border. They see themselves as linked to Germany through this identity, not primarily by being Bavarian. But I think that they like Bavaria for its richness and its 'wildness' and attempts at separateness, being different from the other Bundesländer and stronger. It is like the Catholic Church, more feierlich ('festive') than the Protestants. But as I maintain, implicitly, in the preceding chapter, certain modern ideological positions transcend differences between Catholicism and Protestantism, as the borders between Prussia and Bavaria.

Two major events were usually referred to when someone wanted to depict Linden's history for me - the Black Death and the Thirty Years War. The Black Death meant suffering and hardships and the extinction of great numbers of the population of villages such as Linden. It is from this period, I was told, that French speaking peoples immigrated to the re- 
gion, as several of their own family names are presumed to bear witness. In the face of the Black Death they were victims, as in the Thirty Years War. At that time the Swedes were the perpetrators, invading their region. Considering my Swedish person, people would sometimes joke and tease me for coming from enemy land, wondering if I came armed this time, too. They would ask me if I was aware of the brutality of the Swedes; if I knew of the 'Sweden-stories' told, or that prison bars were also called Schwedengardinen, 'Swedish curtains' (although they were not sure what it meant or if it really had to do with the Thirty Years War). Frau Mann, a teacher's wife, had as a child been afraid of the Swedes. She had heard about the so-called Schwedentrunk, that the Swedes poured water down peoples' throats until they died. ${ }^{7}$

By referring to the Thirty Years War, which certainly seems to be perceived in a different manner than in Sweden and Swedish schools, the tables were turned, so to speak. Here they were the victims and the other was evil and atrocious. 'Accusing' me stopped me from accusing them, for even if Sweden was neutral during the Second World War, they expected me, I think, to side against them, of embarrassing them with my questions and insinuations. ${ }^{8}$ When talking to people later on during my fieldwork they showed more concern with the problematics of 'being German' than with being the victims of Gustav II Adolf's occupying forces. It is this which is my analytical interest and that in one way or another informs my perception of these people.

The Festschrift does not appeal to a singularly heroic past, but to an 'historical' past, one of 'significance'. But there are other views held about the Rosenthal which are less impressive. For some, Rosenthal was, in earlier times, 'poor and backward', whereas others speak of Rosenthal as a fairly prosperous and open region. One day at recess, a group of teachers are talking and one of them, Frau Rasch, holds to the view that Rosenthal had been very poor, 'people were starving here until after the war', and this has had a detrimental effect on the intelligence of the people, she says, also because there has been much in-breeding - da gibt's viele Deppen ('here there are many half-wits'). A younger colleague, new to the school and the area, has quite the opposite impression from having read the 19th century physician Vierchow who travelled widely and wrote books about this area. As he understands it, Rosenthal had been 'open' and a region not so badly off (cf. Gottschalch 1979). On the contrary, through the pro- 
liferation of home-work and small industry the Rosenthal was considered to be flourishing by the early 1900 . There was the railway, the men working in larger industry, the spread of small-holders.

According to some literature, even 'the spiritual and moral level of the people had risen' (Wolff 1905:358), whereas in other descriptions a backward development is lamented (Siebert 1934). The region took a very early part in the industrial development of Germany, it is noted, but this development came to be reversed and the area was in great need. Its glassworks and ironworks forges, as its forestry and salt production had diminished during the years, and this influenced the 'spiritual decline' of the people (ibid.).

Obviously, this region was not exempt from general economic and political conditions in Germany as a whole, which may explain some fluctuations of the literature and their reception. Lindeners, in general, are not apt to see their region as having been backward, with viele Deppen, but hard times are referred to. On the other hand, hier gab's immer was $z u$ essen ('there was always something to eat') during the war, for example, when those in the cities had nothing. And when practically every household was forced to house several war refugees from the East, this was hard, materially and emotionally, but they managed, partly because auf dem Land ('in the countryside') things do work out somehow.

When considering the particularities of German history it is common in historical works to refer to the long fragmentation into petty states and the nationalistic strivings for unification, first realized in 1871 through Bismarck after the war with France; the comparatively late but amazingly rapid and effective industrialization; the early establishment of the beginnings of a 'welfare state', yet the precariousness of its democratic traditions, "social security was provided at the expense of democracy rather than as part of its extension" (Kolinsky 1974:30). The Socialist movement was established in Germany earlier than in other industrializing nations, but has either stepped or been pushed aside by more conservative forces; and there is a constant reminder that there has been no successful revolution 'from below', reforms and democratization have not come through struggle by the people but through state force and legislation, after wars and capitulations (see Claessens et al. 1978, Bramsted 1972, Carr 1979, Mann 1969). 
In the historical exhibition, Fragen an die deutsche Geschichte ('Questions to German history'), in Berlin 1979, commemorating the anniversary of the Federal Republic, the idea was, as stated in the immense catalogue, to "promote historical self-understanding and self-assurance of the present and help provide a guide for future action", which is said to be the "main objectives of the modern historian", an objective which also implies "a critical stance towards the present". 9 One of the main problems to cope with is that concerning the "movement towards a liberal parliamentary democracy which was repeatedly interrupted" (ibid.:26-28). According to Dahrendorf (1969) this lack of a liberal democratic tradition is central to the problematics of 'the German Question'. A question which has been posed in various ways for the last two hundred years.

The German Question, in political and historical discourse, is almost axiomatically taken as a crucial expression of something unsolvable, unanswerable about the 'German situation' in its national and international setting. In post-World War times this question has in different ways been focused on the relations between East and West Germany, a Wiedervereinigung, reunification, or not? On which terms? (Now, since 1990, that part of the question is answered but the consequences are unknown.) The question concerns the problematics of democracy as against totalitarianism, which ultimately must take National Socialism into consideration. Conceptions about what constitutes Germany and the German state, as about being German, brings in history - what are to be counted as crucial points of history?

The 1970 s was a problematic decade both economically and politically. There were upheavals about 'enemies of the state'; the government, ironically the first SPD-dominated government after the war, thought it necessary to control and disarm those who would not accept the promise that they were living in a democratic Rechtsstaat ('state of law'). Anti-terrorist laws were proclaimed. The most well-known, by opponents called the Berufsverbot, ('occupational proscription'), from 1972, established historical links with Germany's 'unpolitical' Beamtentum as the instrument through which the state controls individuals, scrutinizes their loyalty towards the state, demands subordination to its laws and regulations. ${ }^{10}$ This has its significance also for the people of Linden, the teachers in particular. To become Beamte auf Lebenszeit ('civil servant for life'), with the privileges it entails, one must swear the state unswerving loyalty, and keep out of 
even local political questions, such as protesting against the closing of one of the schools. The teachers had signed the note of protest and were forced to remove their names. It was embarrassing and annoying, found to be wrong, but accepted as a necessary evil.

During this period there were Nazi trials being held, there were recurring discussions in the newpapers about the politically sensitive question of the prescription of Nazi crimes. The Holocaust-film was shown on television (in 1979), which had at the time enormous repercussions far from the rooms of film-critics and almost immediately books and articles appeared discussing the matter from different perspectives (see, for example, Märthesheimer and Frenzel 1979). At the same time it is said that there was a "revisionist fascination with the Nazi period beginning in the mid-70s" (Hansen 1985:4).

There were great strikes and lock-outs, the tone was relentless and seemingly militant. The unemployment rate was high. And the politicians, particularly the CDU/CSU, were alarmed about the Geburtenrückgang, the falling birth-rate, which time and again was referred to in the newspapers, as if Germany would cease to exist in the near future. This is a common political worry, recurring during different periods of 'crisis' (see Allen 1986, Koonz 1988). ${ }^{11}$

In what way does this concern the people of Linden? Two of the crucial events or debates which kept the people of Linden alert to the problematics of German history and of being German, were those of Nazism and the terrorism of the RAF. While notions about the past, history, can go back quite far, it is very recent history people mostly refer to, or avoid referring to, when they talk about 'the past'. As Forsythe (1989:138) notes, the term Vergangenheit means, quite simply, the past, but it is often used as a euphemism for the Nazi era. ${ }^{12}$ The Germans are notorious for their history, their 'past', and repeatedly feared for repeating it. People in Linden are aware of this and some will angrily feel that it is time to let the past be, that is, leave them alone - man muss doch endlich damit fertig werden ('it has to finally be finished and done with'). As one woman complained, the Germans are always durch den Dreck gezogen, ('dragged through the mud'). Such statements easily become rhetorical and many, particularly of the left and among intellectuals in Germany, will find them such, but they also reflect a sense of being misunderstood and misrepresented. People are not always willing to deny a past that they also liked while living it. 
Those who are younger find themselves tied to a past that either does not concern them or makes them defenceless.

Many in Linden, when talking more explicitly about this period, also from their own point of view, referred to it as 'the war', whereas when they were annoyed with someone else's actions or foul play within institutions, or the Gemeinde, they would say that it is like the NS-times, wie in der NSZeit, or genau wie im Dritten Reich, ('just like in the Third Reich').

'The war' denotes their own hardships and sufferings (as with the Thirty Years War); the bombings in Aschaffenburg; the fearful coming of the Americans; the men as soldiers at the front, coming home from prisoner of war camps in Russia, or American prison camps. The NS-Zeit denotes the repression, the times when 'little men' made themselves big and evil. It was the 'small Hitlers' who were worst, some of the elderly say. Hitler himself did much that was good, there was work and order. He was betrayed or used by his subordinates, he is not to blame. Others mean that it was Hitler who was the evil one, who wanted war, who hated Jews. Hitler as a person, and the extent to which he is to blame or not, is central for their explanations, which accord with the kinds of varying interests in the person of Hitler during this period - also referred to as a Hitlerwelle ('Hitler-wave'). ${ }^{13}$

Linden was not a unity during the Nazi era, some will remember those who were more active Nazis than necessity demanded - the Mayor who was notoriously opportunistic; the $S A$-Ortsgruppenleiter, who really was 'mean', and still is disliked, 'although no one says anything'. I was told about the priest they had at the time who was 'too outspoken' and soon thereafter was sent away from Linden, giving substance to the danger of being critical of the Nazi regime. The school teacher is mentioned, he who in the night of the pogrom was chased out in the street, and later 'disappeared'. A few men were in the SS, 'but they weren't as bad as it is claimed, my father was in the $S S$, as one woman said. And Hermine Walzick, whose Kaffeekrantz I mentioned earlier, said that she had seen that one of the SS-men in the Holocaust-film had vomited when a small group of naked people had been shot, finding this to be a sign of his sensitivity and humaneness. The SS-man was Himmler, which she had not caught on to. But otherwise it seemed to make people uncomfortable to talk about the $S S$-men in Linden and it was not talked about openly; one knew, that was all. And it was not appreciated in the municipal office in 
Brücken when a student from Würzburg wanted to have some information about four $S S$-men whom he wanted to interview. A young woman working there said that they were all successful business men now in the region, and it was not likely that they would be divulged if it could be avoided.

'It was hard in those days, you never dared say anything critical', but 'those were also good times'. It was a kind of intensification of life, and as some remember their youth, it meant a sense of greater freedom in relation to family and church rules. One felt 'modern', as Frau Hirsch remembers with some delight.

When the Holocaust-film was shown it did not start off any intense discussion. Many seemed to think it was well that it was shown, although it also made them sleepless. Others could not bear seeing it for fear of not being able to sleep. Yet others were angered that this never seems to stop, that it is always the Germans who are evil. It seems that among those born after the war, this was the first time they had received any insight into how it 'really was', they had a feeling that their parents, as well as teachers in school, had never told them anything. Talk would mostly just revolve around the bombings, and they themselves had never asked. The teachers in the surrounding schools continued this silence in so far as they did not discuss the film with the pupils. Only one teacher, as it seems, a young successful teacher in Linden, started to talk to her pupils and she sent to Berlin for

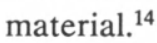

Being born after the war is perhaps a relief, which Helmut Kohl has bragged about, the 'grace of his belated birth' (see Rabinbach 1988), but it also makes it very difficult to know where to place oneself, it is being an outsider of sorts. Some are angry for having to carry the burden of that for which they have no personal Schuld. They feel it is unfair that only the Germans are scrutinized, criticized, detested - 'what about the Russians?! They were just as bad, or even worse, and nobody says anything about that!' Some of the teenagers feel that all this does not really concern them, it is 'history'. As one young girl working at Lewas says, she thought it wrong to send the film, she thought it would be so awful for the relatives of the people, that is the Jews of the film, to be reminded of all that had happened. This somewhat surprising view was also voiced by Hermine Walzick.

Considering the notions people in Linden have about blame, responsibility, guilt, one can to some extent imagine the difficulties they have 
with this. People are preoccupied with blame, guilt - Schuld, in everyday life. Who is to blame for this or that? One is not really willing to take responsibility for something for which one must pay (either in shame by being blamed, or through monetary or legal payment, which also implies shame). You have to take responsibility for your own actions. As one example, teachers are unwilling to associate with their pupils in situations which can mean that if something happens to the pupil the teacher will have to carry the responsibility, that the insurance will not cover it. This is perhaps not so surprising, who wants to pay a lot of money out of one's own pocket, when it is not really your own fault? But then again, why so preoccupied with it as they are, since something hardly ever happens? Why this worry over losing control, becoming involved?

Accepting 'collective guilt' from this perspective does not seem easy, this particular merging of individual and collective. Individually people are not willing to take the blame, neither are they willing to subordinate themselves to an amorphous collectivity which only taints them. Those who were children during the Nazi era or born after the war find no reason why they should carry this burden, and the older people 'could do nothing'. As dear old Frau Hirsch remembers how a Jewish family from Brücken came to them late in the night of the pogrom, when the synagogue in Brücken was burnt down, asking for help, hoping her father would hide them. 'But what could he do? He couldn't let them stay, they would have all been found out'. So the family was sent on its way, into the woods they went, and Frau Hirsch had thought to herself that they would have been on their way to Palestine, she had always hoped that, convinced herself of it.

One is not willing to take the blame for what happened to these people, it would have endangered even more people, one's family above all. And some of the blame must lie with the Jews themselves. It was wrong to just exterminate them, but the Jews were business people, profited from others' work, they should have earned money through their own work, honest work. 'Hitler should have told them that if they did not leave Germany within one year they would be exterminated. As it was, they didn't have a chance to get away'. Frau Hirsch's daughter tries to construct some kind of fairness or reasonableness in the grotesqueness of ordinary life.

Der deutsche Herbst, the German autumn, was closing in as I first came 
to Linden. It was the time of violent attacks and kidnappings by the Red Army Fraction (RAF) and the repressive methods endorsed by the state, finding its extreme representation with the death of the three most notorious, or renowned, terrorists, Baader, Ensslin, and Raspe in the Stammheim prison. And symptomatically this period received the almost romantic epithet of Germanness, darkness and doom, der deutsche Herbst. Everywhere, in store windows, at banks and post offices, and on buses, posters were put up with dismal and menacing pictures of the 'most wanted terrorists', admonishing citizens to help in the search for them.

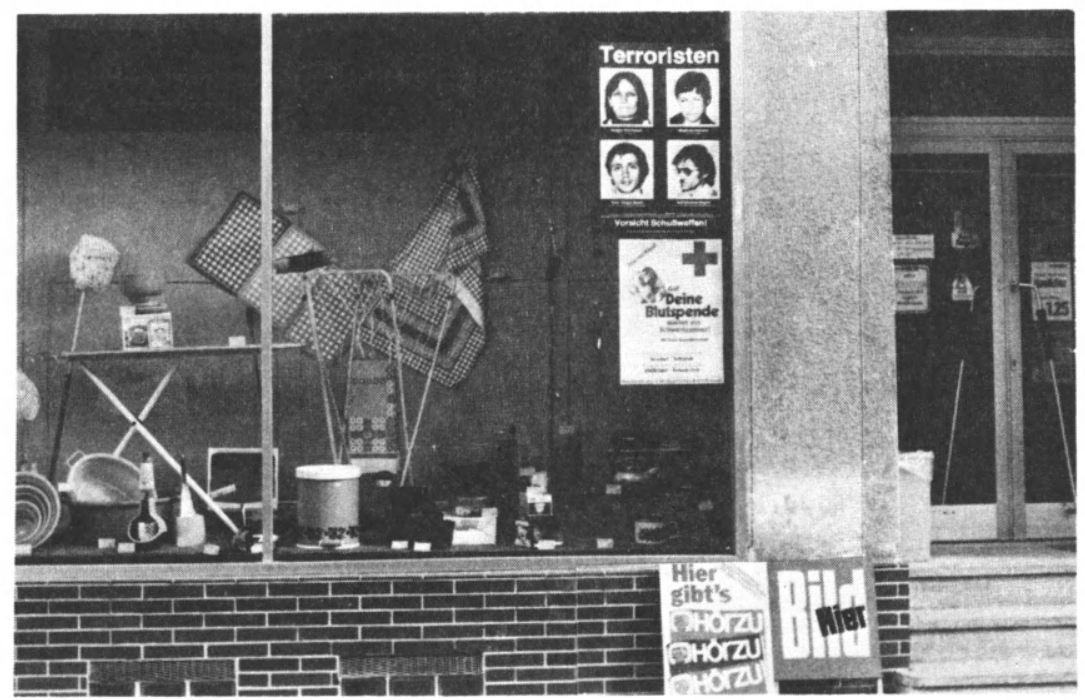

A shop-window in Linden: the orderliness of the home and the disorderliness of the enemies of the state (the RAF terrorists).

These events cannot be understood other than in relation to 'the past'. As Horst Mahler, ex-terrorist, says in his talk with Gerhart Baum, the Minister of Interior at the time, "According to our way of reasoning, this generation (of politicians and bureaucrats) is not fit to represent this state - and thereby us - in so far as it has identified itself or opportunistically collaborated with the Nazis" (1980:25-26). Yet Mahler is not untroubled by the thought that he might have become a Nazi had he not 
been a child at the time. His reasoning evokes a kind of inevitability about the relation between the person and the state, as if the person is at some obscure point fused with the wishes of the state. Part of the 'reaction' of the state towards the terrorists and the general support this found among people, also among most Lindeners, can perhaps be seen somewhat in the terms Kapferer (1988) uses in his comparative analysis of Sinhalese and Australian nationalism. One could think of German nationalist ideology as standing somewhere between the Australian extremely egalitarian individualist ideology and the hierarchical holism of the Sinhalese Buddhists. In Sinhalese Buddhist nationalist ideology the state appears as an encompassing and sustaining whole within which the person moves and is created. Attacks on the state then appear as attacks on the person. If this whole is destroyed then the person will be destroyed, therefore a counterattack must be relentless (which would shed some light on the extreme, and seemingly irrational, violence in view of the alleged non-violent ideology of the Buddhists, against the Tamils). Australian nationalist ideology, on the other hand, is antagonistically turned against the state. It is rather the free and equal individual who is hailed and for whom the nation is the imagined unity of such individuals. In this thinking the state appears as a threat against the heroic egalitarianism of this unity. These notions of state and person as an hierarchical unity or as an unbridged contradiction are not immediately translatable to German ideas of the relation between state, person and nation. Among Germans there seems to be an ambivalence towards the state. The state inhibits and controls them, but is also a guarantor of order and continuity. The terrorists 'attack on the state', their uncompromising defiance, and the state measures taken against them and anyone 'sympathizing' with them, seemed somehow instructive to people of Linden of their own vulnerability, as if they merged with the state and its threatened existence. If one does not show the state loyalty, then towards whom or what can one be loyal, in the last instance? The nation, however essential it is as a form of global identity, is also vulnerable and even ambiguous. It needs the state, so to speak, as does the person.

The people of Linden were not in a turmoil because of the RAF, but their sense of indignation and disgust was unmistakable, they feared them more than the state measures. The state is a Rechtsstaat and must be defended. The Nazi era was invoked by comparing the terrorists with 
fascists, that they strove to take over society and extinguish the middle class, aligning themselves with the rich. In a dictatorship terrorism may be necessary, but not in a democracy like theirs. Notions about the terrorists varied, but commonly they were thought of as academics, upper-class, and perhaps most importantly the result of bad upbringing, or rather lack of upbringing.

History and identity are central in the cultural, and political, construction of memory and among Germans there does seem to be a conflict between 'an urge to forget and an obligation to remember', between the moral of individual responsibility and the problematics of subordination. Living in a Rechtstaat (West) Germans are burdened by the dilemma of reconciling the idea of the benevolent state, securing freedom and justice, and the repressive and destructive possibilities of this state.

As already noted, German writers and scholars have concerned themselves about 'what is German' for a long time. They speak about the German spirit, the good, the evil, the inexplicable. And the Lindeners, in their own way, will at times ponder over this troublesome matter. Some recurring conceptions about Germans are referred to, although it is uncertain if they include themselves in the depiction. To some extent it is an imagined German which comes to mind, an abstraction from the history they have heard about and the history they have experienced. What they take to be German refers to certain idealized features, both positively and negatively charged, concerning a sense of order and ambitiousness. And they suspect that others are envious of them as Germans, because they are well-off, that other peoples begrudge them their good fortune. ${ }^{15}$ 


\section{Separating and binding: the child at home}

The family in Linden stands forth as a private and secluded domain, the door closed to others, the thin curtains always drawn; dirty dishes hidden in the cupboard in case of an uninvited visitor before there has been time to clean up. Yet the family is also a very public matter. It is the concern of everyone, the family as idea, one's own family, the family of one's neighbors, and the 'German family'. ${ }^{1}$ But concern and interest are curbed by forms of discretion, one does not meddle in other people's family life. There is a strong sensitivity of boundaries and their maintenance between spheres of life, and between persons and positions. Such boundaries are not static, but part of the cultural argument.

Living without a family, with no family contact, especially that between parents and children, is being somehow out of place. Unmarried adults, and adults without children and so without the means to form a family of their own, are difficult to place since behavior is often explained by referring to which family one belongs, as to the activities and goals which are central to family life - that of raising children. This is something unmarried people have in common with strangers, in a way making them into strangers. Creating a new family, of one's own, is an act of constructing continuity and order, even though there may not be any observable links back. So a family of one's own is constructing a past into the future. The family is not sacred, but it is the foundation upon which everything in society is held to rest, something which is also proclaimed in political 
debates and rhetorical statements. As the elderly family man, Herr Helm, said in the Wirtschaft after a church meeting, 'a sound family makes a sound state'. With one supreme stroke the 'naturalness of life' is turned into the essence of the good state. Although people will not usually be inclined to make such grand statements, the utterance has its common sense appeal and truth value. They are made aware of being part of something which supercedes the trivialities of daily life, lending their individual endeavors a sense of a higher moral meaning in terms of a collective. But they may also be made aware of the moral burden this implies, and the conflicts hidden in who is to decide which family is sound and which is not. $^{2}$

\section{Household composition and family ties}

I shall first give a brief description of how households in Linden may be composed. ${ }^{3}$ The two households I have taken as examples have some features in common, while other features mark their differences. My point of departure has been two women, one old, the other young, and their families, with whom I quite often associated. I do not describe these households in equally detailed fashion, but the intention is to give some idea of how people live, their daily routines, glimpses of some of their thoughts and habits. The rest of this chapter picks up some of the themes which appear in these descriptions.

Frau Leni Hirsch is one of the first women I came to know and with her and her family I spent much time during my whole fieldwork. I would sit in their redecorated kitchen, the cupboards and stove shining white, a red and black wall-to-wall carpet covering the floor, talking with Leni Hirsch, being served cigarettes, wine, Kaffee und Kuchen ('coffee and cake'). Her husband, Hermann, would come in, sit down at the table with us for a while, joking with me, pretending to make passes, telling me about his work with the farm, about the old days. The grandchildren and the young daughter-in-law, Rita, would come in and sit for a while or just look in to ask Oma for something. Sometimes we sat in the living-room, the TV usually turned on, or just stood outside im Hof, in the yard, when it was warm and I was just passing by. At other times, I joined Frau Hirsch and her married daughter Elsa who comes a few hours every day, as they sat 
in the cellar cutting rubber trimmings for car tires, piece-work for a large firm whose local middle-man is a small firm in a nearby village.

Leni and Hermann Hirsch are then in their sixties, they have two children, Elsa and Wolfgang, both married and living in Linden. Wolfgang has remained at home and has taken over the farm. He and Rita live upstairs in the house with their two children, a boy and a girl. Ever since he was a child, Wolfgang has shown an interest in the work on the farm, so it is 'natural' that he has stayed on and Elsa moved out. For farmers it still is the case, they say, that the preference is for a son to continue with the farm, in this way the name of the Hof continues. Elsa is several years older than Wolfgang, born before the war. She is married to Günther Krafft who is from Linden, employed in a dispatch agency in Hanau. They have one daughter, a school girl of twelve. They live in his parents' house, recently completely rebuilt, and have their own household upstairs while his parents live downstairs. Günther's only sister married a man from Hesse and they live there in his parent's house.

Leni Hirsch and her Hermann live in one of the old houses in Linden, in the middle of the village. It was the home of Hermann's parents where he and his siblings grew up. Frau Hirsch is born in Kleinheim, where a brother and a sister are living with their own families. As newly married she moved in with Hermann and they shared the household with his father, who was then a widower. Thereby, Leni, who was very young then, was given the heavy burden, as she describes it, of caring for the household. As Hermann was the oldest son it was he who was to take over the farm and he managed it along with his father until the latter died. For part of the war Hermann was away and Leni managed alone with little Elsa and her father-in-law. During those years they also had Polish and French prisoners of war working for them in the fields, as did many other farms in Linden and the region. The prison in which they were kept was housed in what is today the local bank. 'And to this day we keep contact with the Frenchman's son', Leni would often happily exclaim. During the 50s and $60 \mathrm{~s}$, there was no one else living with them in the house; nuclear family, house and household coincided. Elsa and Wolfgang went to school and there was no longer an $\mathrm{Opa}$ in the house.

It is with Leni and Hermann, Elsa's parents, that she and Günther have most contact. Also Ingrid, their daughter, goes over to her maternal Oma much more than to the Oma in the house. Elsa visits her mother 
every day on her way home from shopping or from her new job as housekeeper on a half-time basis for a young family with several small children. This couple is not native to Linden and therefore has no Oma who can assist them with the cooking and the children when they work, both of them being Angestellte ('employed'). Elsa feels very close to her mother, and expresses disappointment with her mother-in-law, with whom she never has gotten along very well - her mother-in-law is not a 'warm and loving woman like her mother'. She herself has been brought up with Wärme und Liebe ('warmth and love'), as she says, and she just cannot reconcile herself with the coldness of her mother-in-law. In the beginning, when they were living in the old house, she was always criticizing Elsa for her manner of keeping house.

Rita and Wolfgang live with their two children in the house, intermingling quite a lot during the day with Leni and Hermann, but evenings they spend by themselves, watching TV. The oldest, Tanja does some homework that she did not manage during the day. And they eat the evening meal by themselves. Rita may have ironing left to do, Wolfgang has a lot of paper work to go through since he is not only keeping the farm with his father but is also employed in town as an accountant. He is now also beginning to be politically active, considering to activate the SPD in Linden.

They were very young when they married, still in their teens. It was eine muss-Ehe ('a must-marriage'), she being pregnant. Rita became more or less an extra daughter in the house, and was expected to help out accordingly. And Oma Leni took care of the little girl, Tanja. Usually this form of mutual help is described by the younger woman, the daughter-inlaw, as having been very strenuous, the mother-in-law not having helped as much as she now will have it. The younger woman feels that she at the time was very burdened by all the work, trying to adjust to the whims of her mother-in-law. Many women speak of their first years of marriage, when interaction with the parents-in-law was more close-knit, as feeling controlled and too dependent on the mother-in-law.

Rita wishes to keep close contact with her own mother and her sisters, but cannot see them so often. They live some miles away, and she cannot get away having her hands full of the children and the cooking and cleaning, now that they have one more little boy. One does not just go off visiting for a whole day, as if one did not have anything to do, no work, 
no responsibility. And an Oma cannot really be used for such matters, that is, taking care of the other household, perhaps in particular if it is that of her daughter-in-law. So it is the woman who has her natal family living in the village, or at most in a neighboring village, who can without any prearrangements go visiting and get help with the children.

The other household to be described shows some dimensions of composition which differ a little from the Hirsch household. However, seen in a wider perspective there are several resemblances, as there are between the various households of Linden.

Brigitte and Rudi Grass are a couple in their early thirties. They have two children, Ulrike, who goes to kindergarten, and Michael, who is in school. They live in their own house, built by themselves - with the help of kin and friends on a reciprocal basis. Some say that they help each other build so much that they have not had a free week-end in years, a source of both pride and complaint.

Brigitte is from Linden, as is her mother. Her father is a Polish Volksdeutscher, he came to Linden after the war as a refugee. The parents live in Brigitte's mother's parental house, where Brigitte and her siblings were born. Brigitte's maternal grandfather still lives there with the parents in a single household. Brigitte has a younger brother and sister who are both married. The brother lives with his family in the house of their parents but with a separate household. The sister has married a man from a town in Hesse and they now live with his parents but with separate households. But Brigitte does not know much about her; they have not spoken with each other for several years, because of a family quarrel, and neither of them seems able or inclined to find a reason or a means to reconcile.

During their first years of marriage, Brigitte and Rudi lived in Waldhof, his native village. His parents have two houses on the same plot and they lived in one of them. Rudi has one sister and has had three brothers, one of whom was killed in a car accident some years ago. The sister and one brother are married and live in Waldhof, the youngest is still unmarried and lives at home with his widowed mother. It is the youngest brother who will inherit the house; it was decided that way, the others having already received economic compensation. For Rudi it was in the form of funds for the building of a house. The sister 'married a Wirtschaft' - the son of one of the pub-owners in Waldhof. The brother married a girl from Linden 
(the oldest daughter of Frau Kestling mentioned in chapter 2) and they live in their own house, which they bought.

When they could afford it, Brigitte and Rudi started building a house on a plot in Linden which she inherited from her maternal grandparents, her grandfather still being alive. They built a two-storey house with two separate apartments, planning to let the upstairs one to someone else as a way of financing. They now have Fremden renting the apartment, that is, people from Frankfurt who have no or very slight connections with Linden. The woman does have her mother living in Linden, but she is also Fremd, which was how she found out about the rental possibilities. Rudi and Brigitte are not against the idea that one of the children will want to live in the upstairs apartment when they marry, but they are not prepared to throw out the people already living there if they decide to remain. They also know it is fairly probable that the girl will go to live with her husband's family. 'Well, the children are still young, when they grow up, they may do as they please'. It is 'natural' for a married child to stay on in the house of the parents, but it is not necessary, and the young people should do as they want. That many people build two-storey houses is because it is much easier to get permission to build and to get good loans if the houses have this construction - die Gemeinde will das ('the municipality wants it that way').

Brigitte and Rudi often visit her parents and her brother and his wife, who is from a small town in nearby Hesse. Their oldest daughter, Beate, is the same age as Rudi's and Brigitte's youngest, Ulrike, and the two go to kindergarten together (they reappear in the next chapter). Brigitte is a very outgoing and energetic person and she sees to it that they associate with a few other families with whom they are not kin, and they even celebrate birthdays together which otherwise usually is limited to family gatherings. Sometimes they will make Sunday outings together, perhaps go bowling somewhere in the vicinity. At Fasching, or other village feasts, these couples will often join one another at a table. She and two or three other women have started to go out together on Friday evenings without their husbands, though never in Linden. They drive off to a town where they have pizzas, go to an ice-cream bar, or have a beer. Rudi does not have any comparable association with male friends, he stays at home with the children, watches TV or perhaps goes over to Waldhof to see his brother-in-law at the Wirtschaft, which is a common pastime for many 
men.

Both Brigitte and Rudi are employed workers, she as piece-worker, sewing handbags at home for a small Linden firm, one of the many local small-scale firms which function as agents for the big leather industries in the Frankfurt area. Every day Herr Schulz, the owner of the Linden firm, will come by and pick up finished handbags and deliver new material, or else it is his wife who comes by. They chat a while, commenting on some piece of local news. She has been working for this firm for fifteen years, since she left school, at first on the firm premisses but for the last eight years at home. Herr Schulz is the son of her earlier employer and took over the firm a few years ago. He and his wife are good friends with Brigitte and Rudi and they are part of the network of friends to which Brigitte and Rudi belong. Brigitte uses part of their cellar as work shop and there she spends a large part of her day together with another woman, Frau Halle, who also works for the firm. They sit there with a sewing machine each, working quite hard, chatting, taking a mid-day break for the Mittagessen ('the main meal, dinner').

Each morning, Brigitte and Rudi are up quite early, the children have more than an hour to sleep before getting up for school and kindergarten. Brigitte prepares breakfast for Rudi, she sits down with him and has a cup of coffee. The evening before, she has made him some kaltes Essen ('cold food') to take to work. $\mathrm{He}$ is a mechanic in a very large industry in Hanau and is gone all day. The Venetian blinds are still down, and almost every other house looks pitch black when he leaves and goes down the street to the cross-roads where he is picked up by the four other men in the company van.

The children are wakened, get ready and put on their clothes, neatly laid out on the chair the evening before. After breakfast Michael is told to check that his school bag is in order, that he has his books and pencils. This is not really necessary, Michael always does this of his own accord. Then he goes down to the school bus stop where the other children are beginning to line up. Ulrike who goes to kindergarten, starts a little later. Since they live so close to the kindergarten, Brigitte does not have to take her there, she goes off by herself.

It is now eight o'clock and Frau Halle came an hour ago and is at her sewing machine downstairs in the cellar room. Frau Halle is much older than Brigitte, her children are grown-up, so she does not have as 
much housework as Brigitte and likes to start working earlier. Brigitte rushes around the house, clears away the dishes, she does not have to do them now, no one comes visiting during the morning hours. Yet just in case, she puts them so that they are not conspicuous. She makes the beds, sees to it that everything is neatly put away where it should be, dresses and finally checks that all is there for the noon meal when the children come home from school. When all is done and ready she goes downstairs to work.

Brigitte may take the car on an errand down to the village. If it is almost eleven o'clock she will hurry, to come buying groceries and bread at such a late hour will give an impression of loitering, of being badly organized. It will not do for a housewife to be out so late in the morning. It also gives an impression that Kochen ('cooking', preparing a meal) is no real effort, which means not giving a very good impression. The day's main meal (hot) is served at mid-day. This actually means that many men eat their main meal away from home, or else that a hot meal is served them in the evening - preparing such a meal is supposed to take time. So, a woman, a housewife, seen out in the streets close to noon (most likely talking to someone) feels observed and uneasy, as if she wants to defend herself against 'meaning looks', gossip. She can manage this by wearing her Schürtze ('apron') as she goes out, so that it will be clear to everyone that she is busy, just off on an urgent errand. Therefore, during the morning one sees many of the women with their Schürtze on, even many of those who have plenty of time before 'the bell rings' (cf. Bailey 1971). Brigitte says that it is particularly the women down in the village, the oldest part of Linden, who keep this up - meaning the more 'traditional' women, the older ones, the women living near the church and under the scrutiny of all. But Brigitte does not want to run around in her Schürtze, she wants to dress nicely, she says, seeing to it that her hair and make-up look good. She, like so many other women in Linden, is employed, earns money, and is not 'just a housewife', and wants to look 'chique', even if her main concerns are her children, her house, her husband, and her natal family.

Many will agree with Brigitte that they cannot quite bear the thought of only staying at home, doing the housework, waiting for the children and the husband to come home. Even if this is the most important it also becomes too boring, and the family needs the extra income. And usually 
there is an Oma around who can help take care of the children and the cooking, and so keep up the image of the 'mother at home'. Or else it may function as it does for Brigitte, being a home-worker. Brigitte works a lot, pay is not high, so she has really had very little time over for her children during the day; they will have to manage on their own, but of course, she is there if something happens. When the children were small they would spend most of the day downstairs in the cellar with her, playing while she was sewing.

The children come home from school and kindergarten, school is out later, so Ulrike occupies herself with something until it is time to eat with Michael and her mother. Most of the time the children stay around the house when they have come home, Ulrike may be sent to kindergarten in the afternoon. Michael muss lernen ('must learn'), do his homework, keep practicing, learning. Brigitte checks that it is correctly done, that it is neat and well written, but she does not often have time to sit down with him and practice with him as perhaps she should, she says. At five in the afternoon, Rudi comes home and then Brigitte has finished sewing for the day, Frau Halle has left.

In the evening the family will eat a heavier meal than many other families, since Rudi does not have a hot meal at work. They watch TV in the living-room, if there is nothing else to do. If Michael has done his tasks he may go outside and see his friends for a while, but if he has misbehaved in any way he is not allowed to go. Brigitte, and Rudi, demand that the children are well-behaved, do what is expected of them, and they do not tolerate any 'talking back'. School work and play should be neat and orderly. Often a slap in the face or house arrest is delivered if Brigitte finds that they are frech (sassy), disobedient, or worst of all, have been lying about something.

In both of these houses, that of the Hirsch family and the Grass family, life rotates to a large extent around the house, the family, close kin, and work. Almost all of the women are engaged in some form of paid work, and they find different forms of cooperation among themselves. The children's lives unfold within this realm of work and association, they are cared for by mother and Oma, while the fathers are less practically engaged in their early upbringing. Although the Grass' live on their own, they do envisage that one of their children will want to stay on in the house when they are 


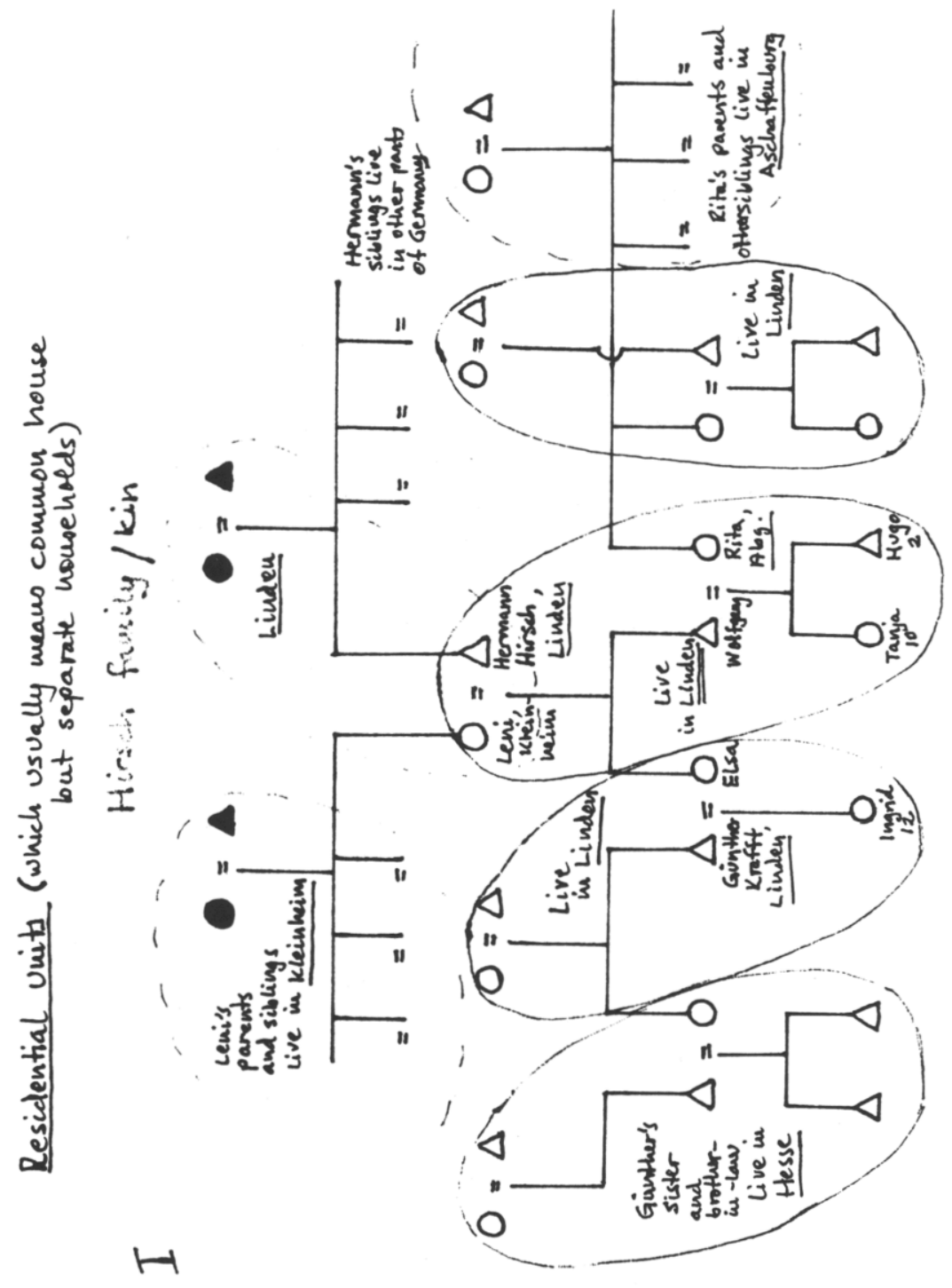




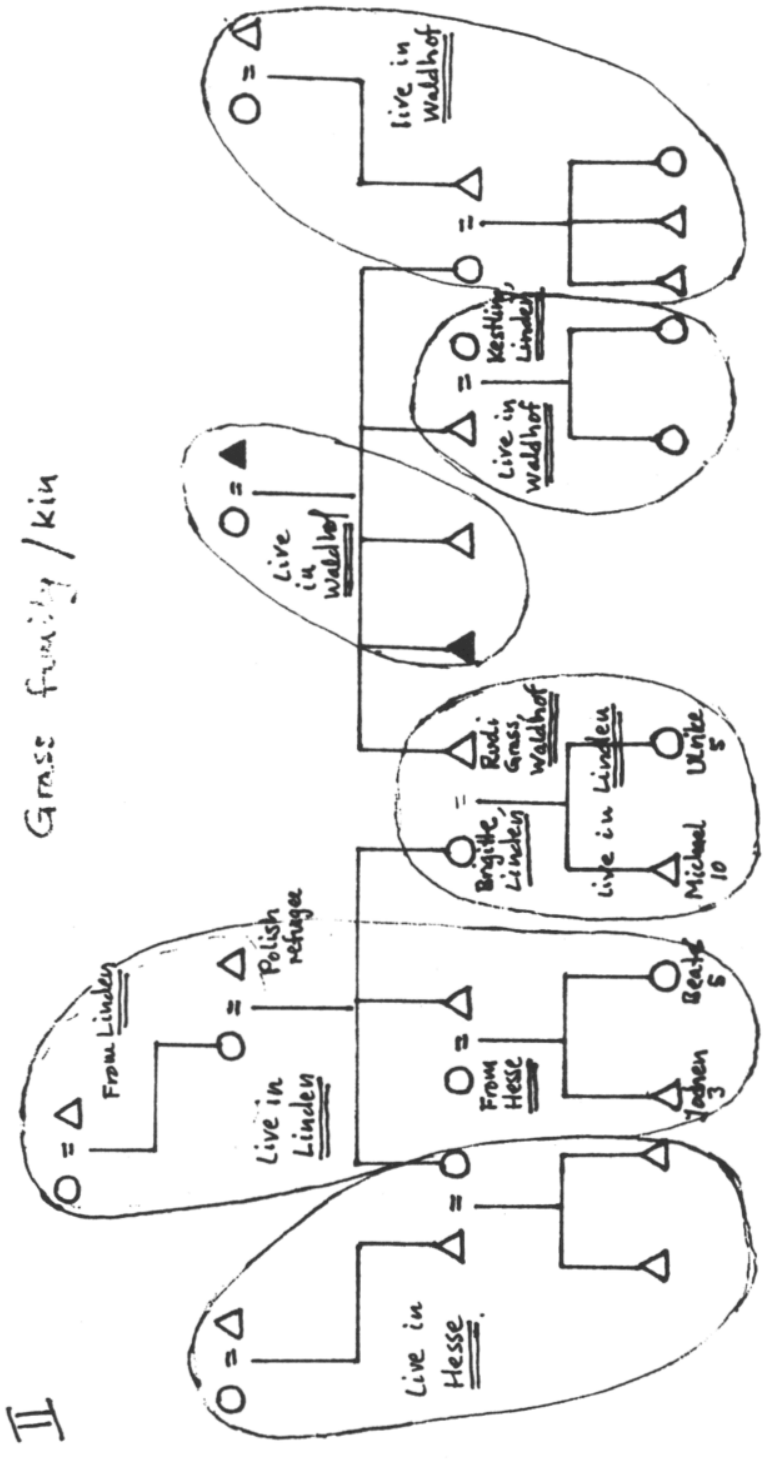


married, even if the question of free choice is underlined, a view also held by the Hirsches even if they intermingle more over household boundaries. Without their young children these household groups would lose most of their impetus, economically and culturally.

There are few people who live all by themselves with no family or kin in the house or at least nearby. The family is primarily defined by the relations between parents and their unmarried children. Husband and wife are the prerequisites for the family, but children - and the house - are the primary core and focus. Usually this family will also make up its own household. But it is quite common that such families do not live completely separated from either the husband's or the wife's parents. People tend to marry young, it is said, in their early twenties, and move in with the man's or the woman's parents - either sharing a household with them or living in an apartment of their own in the house, upstairs. Houses, old and new, are very often built, or rebuilt, so as to be able to accomodate two households.

Household signifies having a kitchen of one's own, that is, people refer to it as a woman having her own kitchen, doing her own cooking, a chore of some esteem. And a kitchen necessarily brings with it the rest of the rooms required for living. Someone has to move in each family if there are several siblings, few houses can accomodate more than two households. There are no explicit rules stating that sons or daughters have particular rights or obligations to stay on in their parent's house when married, although there is a 'traditional rule' that the oldest son takes over the farm. Since there are hardly any full-time farms left, this has changed (cf. Cole and Wolf 1974, Evans and Lee 1986).

When people are asked about patterns of locality, how households are organized, who live in the same house, they will consider it a matter of chance, sometimes alluding to tradition, sometimes practical decisions or personal preferences. Opinions vary, some say there is no greater tendency for a daughter to stay on when married than for a son, others will find it more common for a son to stay on. A mother will perhaps be more in favor of having her married daughter in the house rather than a daughterin-law, 'a mother and a daughter are after all very close', whereas the father will wish to keep a son in the house if farming is still active. Agricultural work is mainly male work, which means that the father and the son would continue to work together, and perhaps most importantly, the 
name stays with the house. But there are also those who do not think it is good for the families of parents and their married children to live in the same house. 'The young ones should be on their own, so that they may do as they please, and so that one may lead one's own life oneself, too'. Considerations of choice rarely refer explicitly to economic conditions. 'It has its good points living together, even sharing a household, during the first years anyway, but every woman wants her own kitchen, each family wants to lead its own life'.

As everywhere, Linden domestic groups ‘develop' over time and there may be quite some discrepancy between actual composition and the views held about them. ${ }^{4}$ If it is common enough for a son or a daughter to remain in the house after marriage, this need not last more than a few years, perhaps 5-10, unless the house is built with two completely separate apartments. The younger family will sooner or later wish to build its own house but then as close as possible to either spouse's parents.

An important factor in the establishement of a household is that many of the Linden inhabitants, as in the whole region, have some land which nowadays is used as building plots for one's own or one's children's use. Inheritance of land is then not a post mortem affair, it is commonly regulated around the time children marry. Some have enough land to provide several children with building plots, others have only enough for one, perhaps two children. ${ }^{5}$ Crucial factors for the establishing of households in the region are then access to land, economic aid from parents and forms of work exchange for the building of a house, as well as exchange of household work, and wages, between mother (in-law) and daughter (inlaw).

All in all, most households depend mainly on incomes from industrial work, either outside Linden, in the larger industrial centers, or in the small-scale industries of Linden and its surrounding villages and towns. This is not to deny the great importance of the extra incomes which derive from work in connection with the household, but for productive reasons the household in general need not have more than two or three adult members, only seasonally are some households in need of extra hands which they find among their close kin, primarily.

The house is of great importance to people. ${ }^{6}$ Plots may be small but the new houses are large, either two-storey or one-storey cement houses. They seem quite exclusive and elegant, with marble staircases inside, large 
hallways, finely decorated bathrooms and kitchens. On the whole, new houses give an expensive impression, and people are also very concerned about how their houses look, being prepared to put a lot of work and money into, both their construction and their decoration and furnishing - except that they are left unplastered for a very long time, making it look as though construction is still in progress - 'to keep taxes down', people will say. There may be other (economic) reasons, but at any rate, these cement-grey, unplastered houses are a common sight in the whole region.

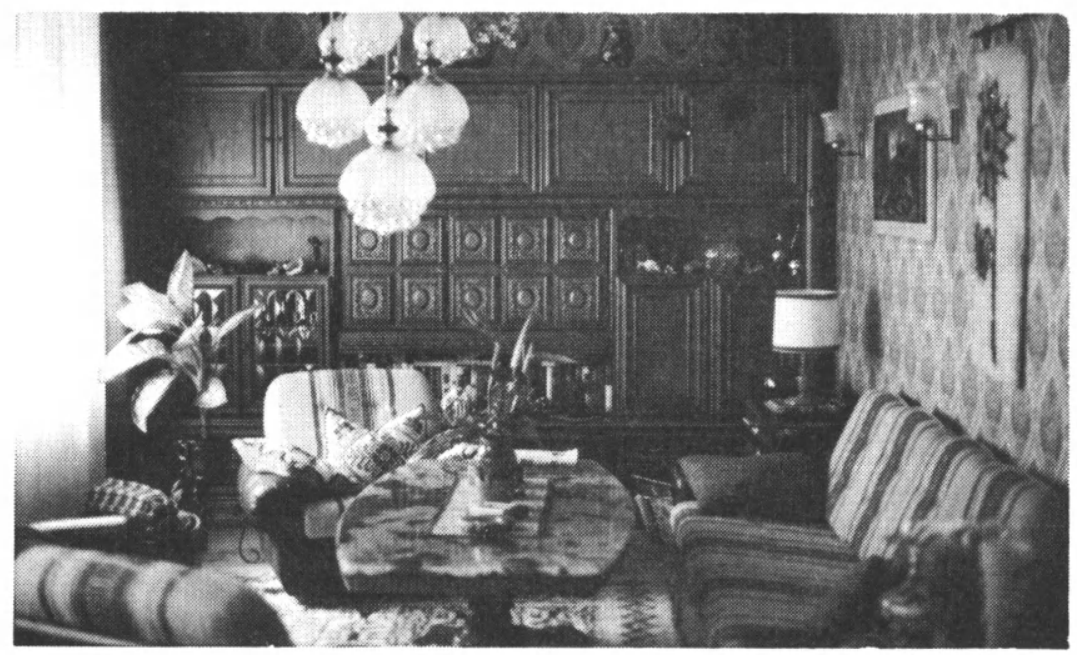

The living room, often finely furnished.

A beautiful and comfortable house, or a new kitchen, a new bedroom, is a sign of well-being and modernity. It is not so much an adherence to a local Linden style, but rather to a widening of this boundary, an adherence to a well-situated modern German way of life - and even 'better than in the city'. And, quite likely, few blue-collar workers can be as well and exclusively housed in Frankfurt or Hanau, as the people in Linden. The inheriting and owning of some land, a house, the possibility of parttime agricultural work, or some other form of family enterprise, the keeping of a pig or two, the kitchen gardening, all this combines to 'raise the standard of living' among people who through their employment alone would not be so well off. Together with such factors as a wide network of 
kinship ties, and a general code of conduct which applies to all social categories, all of these factors contribute to 'homogenize' the social life of Linden, to make class boundaries seem less explicit.

When studying a Western society the problem of kinship will arise in a different manner than when studying, for example, many African or Asian societies. It is not the preeminent ideological or organizational factor in society, yet the social world is almost unthinkable without it - and this no less for those who claim that kinship is of no importance in their lives, that they have no contact with their kin. Because this claim, this way of life - quite possible in modern, urban society - only becomes meaningful in a world where kinship actually is a recognized part of life, even if it only appears in its negation.

Kinship relations may also be considered as mainly a rural phenomenon, people living in cities defending themselves against the limiting factors ascribed to village life. Intellectuals of differing inclinations tend to declare the 'end of the family', which alludes to a fairly static and historically limited definition of the family. Changes are either deplored or applauded. An aspect of kinship in modern Western society is that it coincides to a large extent with the 'family', that is, a set of nuclear families, and many of the relations with relatives are based on an ideology of free choice. ${ }^{7}$

The spatial and emotional proximity between parents and adult married children of Linden, the narrow socio-geographical range within which people usually find their spouses - primarily within a $30-40 \mathrm{~km}$ radius establish a dense network of consanguineous and affinal kin. In such a situation it is difficult to make explicitly meaningful such statements as 'kinship relations are very important to people; kinship is more important than friendship; kinship governs social life', and so on. Kin are all around, everyday social life is to a great extent kinship life. People will, however, not be preoccupied with all of those they consider to be kin; instead it is more important with family and those defined as close kin, mainly siblings and their families. Other factors such as gender and age, close neighborhood, common place of work enter into views held about others and the extent to which they will associate.

Kin give you a sense of belonging and peace and security, as one woman spoke of her family ties, it is a 'natural' kind of life. Nonetheless it also implies a practical burden of much work, extra considerations which must be taken. Kinship controls one's social movements, with whom one 
associates on different occasions, from whom one may ask for economic and practical help. Friends will be to some extent an extension from childhood, age-mates keeping together, but at least for the women, family life tends to loosen such ties. But there are also, among younger married couples, groups or 'cliques', as some of the younger ones say, who periodically associate quite intensely. Friendship may ideally be highly regarded, but is thought of as more precarious than kin relations. One does not know how long a friend will turn out to be a friend, implying that there is some distrust of social relations founded on choice. There is a fear that confidences will be betrayed and once there has been a breach of some kind reconciliation is difficult, and the parties will consider that their distrust of close relations of friendship has been justified.

True, this may also happen between kin, siblings or even parents and their grown children not being on speaking terms with each other for years and years, as with Brigitte Grass and her younger sister. The consequences for Renate, a friend of hers, when she divorced her husband were quite drastic in this respect. They had been married several years, living in a house built on a plot of land next to her parents. She met another man from a town far from Linden, moved there and later marryed him, thereby also abandoning the Catholic Church, since he was evangelical and the Catholic Church does not allow remarriage. She thus tore up a long chain of family and kinship ties embedded in economic and ritual obligations. No one could really forgive her for this, least of all her parents and her sister, with whom she has had no contact whatsoever for the last ten years. Ties of family and kin, and friends, are meant to hold and if they are broken the tendency is to not forgive and reconciliate. Hurt pride is not to take lightly, neither are the boundaries set on social life. ${ }^{8}$

\section{Mothers, Omas, and others}

The mother is the central figure in the family and the household, and particularly the senior mother, the Oma. Die Mutterliebe ist wie die Ordnungsliebe ('the love of mother is like the love of order'), a not unambiguous saying alluding to this centrality of the mother and, referring to my earlier discussions, the concern with wholeness and unity which Ordnung, implies (cf. chapter 1). ${ }^{9}$ Mothers should, ideally, stay at home and care for the small children, but most young mothers are occupied with some kind 
of wage work. The mother's allowance only covers some six weeks after birth. It is not an uncommon situation for these young mothers to be 'kept out' of housework and child care. The Oma will more or less run things and seems to take pride in being the 'main mother'. If she has a daughter, living in the house or at least in the village, they will most likely interact quite intensely, the daughter seeking the advice and support of her mother (this tendency has also been noted in several studies from England, cf. for example, Bott 1971 and Young and Willmott 1971).

On the whole, with all the attempts to loosen a child's dependence on das Elternhaus ('the parental home', the family), which is one of the stated goals of kindergarten and of the parents themselves, although more ambivalently, adult children, daughters especially, appear to be very bound to their families of origin, their mothers in particular. The everyday run of things, the care of the children depend on this relationship, and it belongs to the core of one's emotional life.

The tendency to move away, build one's own house, even if very close to the parents' house, only after some years of marriage, has to some extent something to do with these close and bounded relations. Children who have reached school age no longer need the kind of care which an Oma bestows, and the Oma herself is no longer as willing to bestow it. She may feel that now it is high time that the parents of the children, the mother, take over the responsibility more wholly. And parents of school children find that their, that is, the mother's presence and supervision is needed. It is an area which the Oma cannot manage. This does not mean that ties are severed, rather that mother and daughter (daughter-in-law) begin to reach equal status, the younger woman wanting to be her own 'boss', preparing herself for her own position as Oma. The older woman will also let it be known that she is looking forward to resigning some of the practical burdens.

Older women, Omas, may appear to be very strong and important persons. Very much of the interactive energy rotates around them, the daughters, or daughters-in-law, seeming to be socially less active and decisive. This, I would contend, is not so much a sign of a woman's particular personality, as of the fact that she is an Oma. Somehow it is she who is the mother, she is surrounded by a number of dependent children of different ages. It is not until her daughters are Omas themselves that they will be as 'real' mothers as she is. 
Usually people will marry when they are quite young, and the first child is either on its way or will be soon, and it seems as if the young woman is not prepared for the role of wife and mother. She is in many ways still her mother's child, she is not thought of as being very capable - young girls are not taught the intricacies of the able housewife. They are not very good cooks and they are not prepared to take care of babies. During their teen-age years they are not expected to learn all that which the mother knows. It is first after some years of marriage that they more definitely step into the role of mother and housewife and take over more and more of the responsibility, sometimes when Oma declares that 'now it's enough!' The young, newly married women and mothers work and stay out of the way for a time.

Being childless cuts family life short. The Oma becomes superfluous, the routes which social interaction with persons and families and other institutions can take become restricted. For both men and women it is difficult to be childless, but more so for the women, their social life is to a greater degree hampered in the village. Men, as supporters, are occupied all day working. Whether married or not, whether having children or not, they may be seen out on their own, at the Wirtschaft, participating in different activities organized by the associations. Women, on the other hand, associate with others more directly through the links that their young or adult children and their husbands will motivate. An adult woman, being of marriageable age and potentially a mother, does not move as freely about the village, seeking company, she even has less reason to visit her own mother if she is not a mother herself. And all of her age-mates will be having children. I do not think that she is considered to be a sexually dangerous woman, a threat to other women in luring their husbands from them. Rather she is an anomalous woman, not the social being she should be. Somehow she is not a real adult, she continues to be a child of her parents but cuts the process short by not becoming a parent herself. For both men and women, having no children of one's own means having no family of one's own, one is neither child nor parent, but someone inbetween. A person without a family has no 'natural' reason to build a new house, or redecorate the old one. Perhaps most importantly, without children there is no one to bring up, this very essential social and moral task of the adult person. ${ }^{10}$

The position of being unmarried is the most troublesome, especially 
for women. A woman without a husband, and so without children - without family - is partially closer to a male life than a female life, as lived and defined in Linden. She must earn her whole living and has no one to cook for, no one to clean for, no one to go to church for. As time passes, no one to really visit. Of course, she may be living with her parents for a while, but not so that she takes the place of any married siblings. Also she will be depriving her mother of being an Oma, a senior mother in relation to herself. A man will have an income from employment whether married or not, and he can help support his parents, he can help his father with farm work if there is any, or the family firm. Being unmarried has, of course, various reasons and no one will consider a widow or widower as in the same category as someone who has never married, especially if there are children with whom to live. And the Pfarrer, living in prescribed celibacy, having his Fräulein, the housekeeper, take care of his house and the cooking, is also exempt from the category of being unmarried, although sometimes ridiculed for it behind his back.

Differences between men and women are not in all respects very great, nor are women unable to manage, to find a nische in which they may realize needs and wishes in life, like Frau Lahn. She is an elderly woman who has lived some years in Linden, renting a few rooms in the house of a widow, and engaging herself quite actively in the church. But she has certain solutions to her position. She is not living in her native village, she has made the church the center of her interests and the church does not require its servants to be married, on the contrary sometimes, and she is, as of course everyone becomes, old. Age does become an asset in life. Yet again, not always, as for poor old Irma Henzel, who is unmarried, living on her parental farm, at first with her parents and a married brother, who took over the farm. The parents died and Irma has lived on in the house, undecidedly belonging to her brother's household, helping out. She has never gotten along with her sister-in-law. For years now they have not been on speaking terms. The brother died some years ago and the two old women live in the house with a son of the brother who now owns the farm. $\mathrm{He}$ is married and has two children of kindergarten age. Irma has no pension, and no real rights, the relatives not willing to support her. So she arranges cleaning jobs, helps out in the kitchen of the Wirtschaft, thereby managing to keep herself going and eating, and an odd part of village life. This does not imply that she would have had very much better 
relations with her sister-in-law had she been married, but it is likely. She would, first of all, not have lived on in her parental house, and even if she had she would have had a completely different economic and social position with a family of her own. Most importantly, she would have had children who would have needed her in her capacity as Oma, and they would have been obliged to care for her in one way or another in her old age, at least potentially, and at least as 'good company'.

A man will most likely have an income, from the land, in part, and from employment. In practice, this very often applies to women, too, but their earnings are not as large. They do not as often work all day, they seldom earn enough to support a whole family, and women are never regarded, by anyone, as main supporters of the family, or sometimes even of themselves. They tend to speak of their money as 'pocket money'. It will be regarded as financial help for an expensive house, for rising costs, and so on. Their money is needed, and this they are well aware of, although it may be talked about as something extra, something which is not quite necessary (cf. Sommerkorn 1988 on mothers in Germany who are employed). Economic aid from parents, as well as forms of exchange of work and food, may make the necessity less obvious. Women do work quite a lot, many wanting to have some form of employment, to have something to do outside of the household. But no one questions the capability and obligation of the man to support wife and children.

To sacrifice family life for a working career is quite suspect, and it is difficult to include such a woman in the everyday round of things. It will vary, to some degree, in relation to what kind of woman it may be - the outsider, that is, someone who has moved to Linden from outside the region, is different and if she is unmarried the explanation is unknown, to be found where she comes from. For example, the dentist is a woman from another part of Germany. She is a middle-aged, unmarried woman and has been living in Linden a few years. As a professional with a high social position she would not easily become friends with the ordinary Linden person or family. There are a few who, in accordance with their position (teacher, priest, doctor, etc), could be thought of as possible candidates for association, but actually she keeps to her few friends who come visiting from where she has lived before. But she is a kind of honoured guest of the Garden Association, and is there a lively and sociable participant. She can, on the face of it, associate as easily with men as with women, in some 
situations more easily with men, and in this respect moves more freely within a male cultural sphere than other women of Linden. Her position and age desexualize her enough for that. The women of Linden have very little in common with her, the men more so, but her social position surpasses theirs, or most of them. But, as I see it, her unmarried status is what makes her seem somewhat anomalous, making her less female, so to speak. This also applies to the kindergarten head teacher, who also is a 'stranger' to Linden, without family or close kin in the vicinity. Nobody knows a person without a family or even close kin, that is, one does not get to know them, there are no links leading in to them.

Fräulein Hart is a middle-aged woman, unmarried. Her two sisters are married, living in neighboring villages. She has worked in one of the local stores before it closed down. After that she has had other jobs away from Linden. When I was in Linden she was on long-term sick-leave. Frl. Hart is born in Linden and has lived there most of her life, though not always staying with her widowed mother in the house. But thinking, as she said, 'that the old woman needed help and company', she moved in with her some years ago. A year later, though, she moved out, having received a municipally owned apartment close to the fire-station. She just could not stand living with her mother. And her sisters accused her of beating her mother, since the old woman often had black and blue marks, and they both always complained about her, to anyone. Frl. Hart said that now they would all see that she got her blue marks from falling down, she walks so badly. She has never gone to see her mother again. If the woman still has her black and blue marks, the story does not say. That she often did fall is a known fact.

Many people are troubled by Frl. Hart. At times there was much talk about her, how mean she is, what a sharp tongue she has - she herself is proud of her outspokenness, she has always told people what she thinks of them, she says. Her behavior is considered odd, her illness has been highly questioned, many thinking it has been just faking (but she did die from her illness towards the end of my stay). She was in a way a strange woman in this village, outspoken, openly critical and seemingly oblivious to social opinion. She had been a harshly beaten child, she did not get along with her close kin. There was something disturbing about her in people's eyes, but that which was most disturbing was her flagrant denial of motherhood. She obviously refused to marry, had absolutely nothing 
good to say about her mother and would not take it upon herself to help her when she was old and in need (although she had tried). She would not even yield to the priest's personal visit admonishing her to call on her mother on Mother's Day. She thought it quite unheard of that the priest should meddle in that, although she was also moved by his show of care, as she interpreted it.

People will complain and gossip about die Oma, but that is still restricted; and one tends rather to talk more in general about the institution of Oma. The down-right hateful and desperate presentation Frl. Hart gave of her mother and sisters is not usual and it is disturbing to people. Although she thought her mother was so mean, she did move back home again when her sisters married and moved away from Linden, to take care of her. She felt pressure on her, she said, to move back home, and she did spend some years with her. According to general opinion this was the only right thing to do. It is not necessarily so that people deny the truth of Frl. Hart's description of the extreme beatings she got when a child, or that it was not understandable that she hated her mother. The mother was not a particularly loved person in Linden either, but in the last instance all that is irrelevant. A daughter, especially, should not forsake her mother, not openly. Whatever the mother has done, she is a mother, and has a right to be shown respect and devotion.

\section{Small children and the problem of dependence}

The early years of childhood are marked by a closeness to the mother and her substitute - or her superordinate - the Oma. And all the years until school, and even later on, a child is held close to the home, the house quite concretely. One does not see many children in the streets on their way to some playmate or to the ill-kept playground, particularly when the weather turns cold. They stay at home, play im Hof, or stay inside quite a lot. To play outside also means to change clothes, a child home from kindergarten must change his or her nice clothes to something which is allowed to be dirtied.

Children are sent on errands, to the baker, the butcher and so on. They are off to their music lessons, to church. They sit at home, in the kitchen, or at the dining table and do their homework. Older school children, especially the boys, ride around on their bicycles, the girls walk together 
in small groups of two or three, and when it is warm outside the parking place in front of the church is a popular place to hang out. The smaller kindergarten children may be seen right outside the house, the boys with their pedal cars, the little girls less obviously noticeable with a comparable toy.

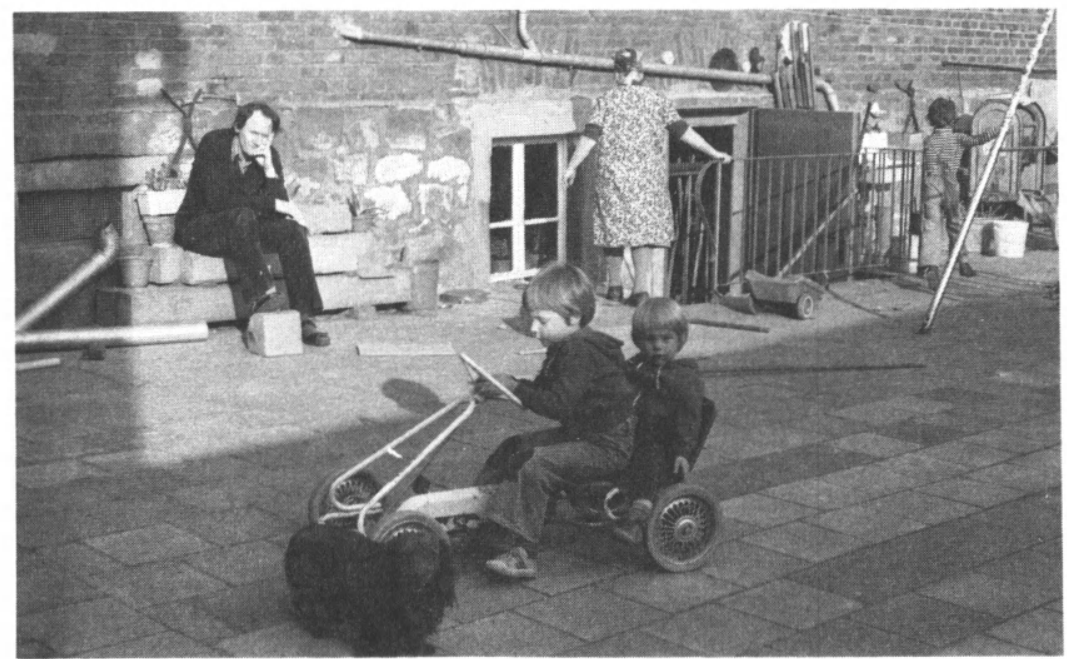

Im Hof, a place where family members spend much time.

On Saturdays every family member, except the small child, has his or her duty in helping cleaning Haus und Hof. Usually it is a school child who will sweep the yard and the sidewalk in front of the house. Father washes the car and a son will more likely to be helping his father than a daughter - or else the father spends most of Saturday afternoon in or near the car cleaning it by himself, listening to some football match on the car radio.

Sunday morning (for some Saturday evening) the children go with their mothers and fathers, perhaps also with Oma and Opa to Mass. The older children prefer to sit with their age-mates apart from their parents. Not all families go to church, but there are still quite a few with young children who take them to church. This is held to be even more important for the school children since it is part of their school obligations, the 
Pfarrer will comment on those who never show up at church.

Small children may accompany their fathers to Frühschoppen, i.e. a few hours at the favorite pub after Mass until dinner at about one o'clock (this is a nation-wide pastime which even lends its name to certain Sunday morning television programs). For many men this is the only time they take their small children somewhere on their own. They help their wives 'babysit' while she is at home preparing Sunday dinner, the most elaborate dinner of the week, and the father also gets a chance to show off his little son or daughter, although perhaps a son is preferable in these situations. After the Sunday dinner there may be a Spaziergang ('walk') with the whole family in the woods, along the fields. Or else a particular activity is planned, like visiting relatives for coffee and cake, partaking in an event arranged by one of the associations, or just staying at home, perhaps watching television. Although life may seem very family oriented, it would be misleading to see it only from this perspective. Many 'outside' activities are planned and organized by the different associations and many are keen to participate when the church, the music association, the sports association, apart from kindergarten and school, arrange seasonal feasts, tournaments, and meetings. Much time may be spent at home, im Hof or in the garden, but the family is lived in relation to a wider social and cultural context, which should be held in mind even if this aspect is not so prominent in my analysis.

The small child is a cute, funny little thing which in company is observed and commented on, teased and laughed at; repeatedly made to say and do certain things, name persons and artifacts; given sweet drinks, candies, and told no, no a number of times, getting fingers slapped when touching something forbidden. Although this may have several aspects which seem to be an indulgence in the small child, it is not the period in a child's life which mothers seem to appreciate the most. It is a period often experienced as trying because of the dependence of the child on the mother, on a caring adult, and because the main orientation is the body and its functions. The two aspects go together, of course. Everything becomes oriented towards the needs of the baby, which binds the mother to an image of the body, nature, which may seem repulsive, not necessarily because of 'dirt', but because of lack of self-control (which would be dirt in Mary Douglas' terminology, 1966) and because of the extreme vulnerability a small child or infant expresses. The body is obtrusive, as is the great show 
of dependence.

The small child is one to be touched, fed, washed, clothed, put to sleep. The aim is that the child should learn to manage 'on its own' as soon as possible, that is, not be dependent on the breast, the pacifier, or attention (company). And the child must learn that 'reality', 'life' is not something that will adjust to the child; quite the contrary, the child must adjust to the limits set by reality, and the primary means to achieve this is to learn to control one's body - by being controlled through it. Many mothers prefer not to breast-feed. They find it 'messy', feel unfree, and worry that they will not have enough milk. Several mothers who say that they have tried nursing found that they had no milk. Such reasons may be connected with the underlying unwillingness to breast-feed. They will also say that they do not want their breasts to become deformed, or that it is embarrassing to nurse in front of your husband. ${ }^{11}$

A baby should not be carried around too much, or picked up as soon as it cries, otherwise it will get used to this and become much more demanding, spoiled even, always wanting attention. A child may by some mothers be left alone in bed for long periods, so that she can feel less hampered in whatever else she is doing, that she even may go off shopping while the baby is at home alone, 'she (or he) can't get out of bed, and she sleeps and is quiet anyway', a child must learn to be by itself.

The child who is sauber ('clean') by $11 / 2$ is a child to be praised. Toilet-training usually starts early, about 6-10 months, sometimes before six months, the mother rushing to the pot when she notices that the baby is 'pressing', or just holding it regularly over the pot or the toilet after a meal, before the bath, and so on. A child who is slow to learn and must wear diapers until it is two or more - which is quite common - is in various ways excused to others by saying that some are early to learn one thing, other children do other things early, like talking, walking, 'you can't expect everything'. It is also complained about, yet mothers will have noticed that a child does not really get definitely sauber before 2-3 years of age no matter how early you start training it. Still, to just let it be seems wrong, one must make sure that the child learns. One way of managing is to let the one-two year old walk around without diapers, just little panties, especially during the warm season, telling the child that now it is so big that no diapers are needed any more. The child is told to tell mother or Oma as soon as it wants to make Klein ('small', i.e. urinate) or Gross ('big', i.e. 
defecate). The mother, or Oma, will then be after the child as soon as she thinks the child needs to go to the toilet. The little child is not necessarily scolded or punished for being unsuccessful, that is not unexpected, but the show of love and praise may also be momentarily witheld. With pride a mother will brag about her child being sauber early, by $11 / 2$. She is a good mother (or Oma) and even has an intelligent child.

Most of the small children either suck their thumb or have a pacifier. The pacifier is usually taken away from the child quite abruptly when it is about one or two years old. The child is told that the pacifier, the Schnuller, is lost, that the dog took it, that the parents sold it, that it was so old and worn out, quite sickening, pfui!, that it could not be used anymore. And the child will have to accept this, having some hard nights getting over it, but then it is 'all forgotten'. The child is thought to be reconciled to the fact that the beloved Schnuller was 'no good' and is forever gone. Mothers will tell each other stories about this, laughing, not unkindly, making faces to show how repulsive they find the whole business of sucking. The child who sucks the thumb causes more trouble and the parents will often smear it with something very distasteful - but their success is less immediate, the child does not give up as easily. As Frau Edelmann remembers of her daughter, when she was about one year old they smeared all kinds of smelly, repulsively tasting stuff on her thumb to make her stop sucking. They wrapped it in cloth, "but not until she got a little sore on her thumb when she was $11 / 4$ years old did she stop because then it hurt when she put it in her mouth, so, actually, that was a good thing with that sore'. And Frau Edelmann tells her listeners, laughingly, that she herself sucked her thumb, secretly, until she was eleven years old.

The main rationale for stopping the use of pacifier and thumb-sucking is that it is bad for the teeth. As one mother and father had said to their little son, if he didn't stop using his Schnuller he would surely get dog's teeth, Hundezähne. For a long time he was so worried, the mother says, and kept asking them over and over if he had gotten dog's teeth. This tale causes much laughter, but they had at the time regretted having frightened the boy so much. His pacifier also disappeared one day, this is now a few years ago, and 'there was never any trouble, he never asked about his Schnuller'.

There are quite a few young people with braces on their teeth. From this one could assume that the parents have not been particularly success- 
ful in stopping their children from sucking the thumb or the pacifier. That may be, there are probably children of today who are as secretive as Frau Edelmann was. At least judging from what many adults say, they sucked their thumbs for many years after officially having stopped, and none of them have had, or seemed to have needed braces. I am not trying to prove or disprove anything about the connection between teeth and thumb-sucking. The preoccupation with teeth and braces is an answer to certain presentday professional concerns, and so enters into the total preoccupation with the body, which is mainly expressed in attempts at readjusting it, manipulating it into the 'ideal real', through worries about disorders, illnesses, lack of control. The child should submit its body not for pleasure but to superiors external to its body, the parents, 'reality'.

The pacifier is gotten rid of early and energetically, but the bottle is kept for years, very often filled with sweet tea, or perhaps Kaba (chocolate drink). It is not unusual that 5-6 year olds still have the bottle, not at meals but between meals. This is not discouraged in any way as emphatically as 'pure sucking'. As one mother (the aunt of Karl who is mentioned below) said of her son who is in the first grade, if she would let him he would still like to have his bottle, he thinks it tastes so good, 'but he really is getting too old for it now'. There are also a great deal of sweets - candies, chocolates, and Limo (orange soda water) - consumed by all children from infancy. There are hardly any restrictions in this case, children are given sweets by all adults wherever they go, parents are seldom an exception, although they may complain about a child who nascht $z u$ viel ('eats too many snacks, too much sweets'). Teachers may also at school meetings mention to parents that it is not good if a child nascht zu viel. Children should eat regular meals and not be allowed to eat so much between meals. But nothing is really done about it, no one seems to take it very seriously, sweets and children are inseparable entities. So, on the one hand, there is control and prohibitions, on the other, indulgence and nonrestrictiveness. The two are opposite, and complementary, parts of the same order. The emphasis should not be on seeking pleasure, and irresponsibility, by turning inwards to oneself, but rather on receiving pleasure from the other, the superior, who decides to give it.

I shall now relate some features of the interaction between adult and small child by referring to a situation with Karl, who is almost two years old. As yet Karl has no siblings. He lives with his young parents in his 
maternal grandparents' house. One afternoon he has accompanied his maternal uncle and his wife on a visit to friends for Kaffee und Kuchen. Karl's parents are away on a skiing vacation for two weeks, his Oma could not take care of him as she works away from home, so he is staying with his aunt and uncle. 'Oh, he's a good boy, but a bit fussy', his aunt says.

They spend most of the visit talking about Karl, his habits, watching him, commenting on what he does, admonishing him, giving him to eat and drink. The aunt tells of how early he wakes up in the morning, at six o'clock, 'but I'm not to take him out of bed, Sigrid (Karl's mother) said, he's to stay there until nine or he'll just get used to it and she won't have it'. So Karl is kept in bed, he stays quiet, she doesn't know what he does, hears him move about in his bed, babbling to himself. Renate, her friend, thought it was expecting a bit too much of him, keeping him in bed that long, an hour or maybe two, but three, that's too long.

While they are there, Karl walks around in the room, looking and poking at things he finds interesting, but he becomes particularly fascinated by a small calculating machine standing in a bookcase. His aunt keeps calling nein, nein! to have him stop and leave it alone, whereas Renate says it doesn't matter, he can't break it. But the aunt persists, slapping his fingers, finally lifting him away. Later, when he is playing with his little rubber ball, bouncing it around the room, she does not protest, no one says anything or makes any sign of dislike. It is his ball, with his own things he may do as he wishes, and children play and romp around, that is their way. Karl has no right playing with the machine, and his uncle and aunt do not wish to take responsibility for it in case it is broken. Karl should obey when he is told something, and if he is told no, this cannot be changed into a yes, one must be consistent. Otherwise a child will never learn what is right and correct behavior, there will only be confusion and so disobedience. A child will start making unwarranted demands if no can be turned into yes just like that. And it is Renate's business to say yes to the calculating machine, but not to comment on the ball, since it is not hers, that would be the responsibility of the aunt, in that case.

They talk about him, how badly he eats, laughing at how funny he looks when he wrinkles his nose. He is given Limo and candy, and chocolate the whole time, and the aunt is constantly at him to wipe his mouth and nose with a kleenex (Tempo). They have him say different names, words, and keep repeating them and nagging him until he says the right 
word. He is told to give Renate, called die Tante ('aunt'), some chips from a bowl, but he will not do it, and they keep at him, telling him that die Tante will cry if he won't give her some. He looks at her and still refuses, and they keep on telling him to do it, laughing, scolding a bit. He finally moves away and they leave him alone for a little while. He finds a little piece of hard plastic or something like that lying on the floor, picks it up and puts it in his mouth. They see it and they all rush at him, trying to get him to spit it out, his aunt puts her finger in his mouth to get it out, but he keeps his mouth firmly closed and closes the scenario by swallowing it. This makes them calm down, there is nothing to do. He is left alone, they watch him to see if anything seems wrong, but no, it is all right, 'it will come out at the other end', the aunt says. She shakes her head, 'they are so quick those little ones when they do something they know they're not supposed to and no one is keeping an eye on them'.

During this whole visit the little boy is the center of attention in quite a common way - watched, commented on, laughed at, teased, told to say and do different things, given almost limitless amounts of sweets and Limo. The little children are enjoyable to the adults in this way, who have them do and say things which make the adults laugh. This show of attention usually does not correspond to the attention the child gives the adults, and in the home small children may instead be left to themselves for long periods.

There seems to be a certain ambivalence among mothers as to the amount of dependence and closeness they are willing to tolerate, how much of the 'a-social natural' life they can contain. This ambivalence may be one reason why mothers leave their small children or babies at home alone and go off shopping; or parents go visiting in the evening, leaving the small children at home by themselves, without using an Oma as a resource for baby-sitting. This may also have a bearing on the fact that so many small children spend days or weeks in the hospital with no, or very few visits from the parents. They have tonsils removed, or adenoids, indistinguishable fevers, pneumonia, suspected meningitis, cramps from vaccinations, brain concussion. They are kept for observation until a certain diagnosis can be made, and time set for recovery is long. Many parents will afterwards come to the conclusion that the child has been kept in hospital for no good reason at all. As one father said, the hospitals want as many patients as possible to get the funds they need, so they keep them longer 
than necessary.

Mothers will tell each other of the terrible experience it was for them, some of the fathers hardly bearing to go along on the few visits allowed, because the child would cry and scream so desperately. 'Oh, it was awful, he screamed until he vomited', 'I could hear her screaming all the way outside', 'never again, never!'. The staff is heard complaining that the visits just upset the children, that they are quiet and calm as long as they do not see their parents, this way making the parents feel uncertain, guilty and underlining the ambivalence to the child's dependence and weakness.

One or other of the small children take matters into their own hands, so to speak, like little Hugo Hirsch, who fell off a sofa and hit his head. After a day or two in hospital he refused to let the staff feed him, cried and screamed until they had to call in Rita, his mother, to come and feed him. He had unusually much homesickness, the staff complained, and Rita was caught in a fix. She felt compassion for her little boy, yet wished that he could just take it, be good and do as was expected of him. At the same time she was proud of his strong will, and perhaps also of the fact that he preferred her to the staff. Although knowing that the boy needed her and was very clinging after coming home, she and Wolfgang are not prepared to give up their plans for a two-week vacation over Christmas, leaving Hugo with his Oma and Opa. She is not quite happy about it, but the boy is over one year old and should not have to be so dependent on her. The assumption is that afterwards everything will work out, "children get over things, they forget'.

Even if parents vow 'never again', they do it again and again. Not necessarily to the same child or within the same family, although that is more common, as in Hugo's case. His older sister spent many weeks in the hospital in Frankfurt when she was five years old, due to an eye operation. The experience of the other is not used to influence one's own actions. Of course, one can say, what choice do people have? If a child must go to hospital, especially when told so by an authorized person, the doctor, should parents then not do it? And if hospitals deny parents the right to be there with their child, what can they do? It is not the privilege of parents to openly question and disregard the rules of the hospital, you cannot change what authorized others do, you have no right to meddle in that for which you are not qualified. The point is, what these authorized 
others claim to be right may hurt people, make them feel despair, but it happens within recognized and understood boundaries, their structures of thought coincide, even though a particular individual may at any given point feel unhappy, offended by it.

The house is a lively place and family relations may at times become quite intense. Within this realm of house and home there breeds a sense of dependence which is both encouraged and discouraged. It changes over time but without really altering focus, that of a problematic closeness to the mother. The small child is the central spectacle in the family, to be watched and formed, and taught the basic elements of reality. This reality is made known through the body, which is groomed and manipulated and indulged in. The child is rapidly 'separated' from the mother by having it learn control of the body and discouraging 'aimless pleasures' such as sucking only for the sake of sucking; the child should not be spoiled by being picked up and carried around too much, as soon as it demands it, or being allowed to sit in its carriage when it can manage to walk to the store. 'Reality' is not to be altered to any degree for the child's sake, the child must rather adjust itself, succumb to life as it is given.

The act of separating is not straightforward and seems to generate re-enactments of dependence later in life. The child should not cling to its mother as an infant but should never leave her, or the idea of her, and the natal family, when adult. The child is discouraged from sucking, from putting things in its mouth on its own, yet it receives the bottle with sweet drinks with great indulgence, it is given large amounts of sweets by all adults at any time. The act of receiving, of being given, binds the individual to an authority. It is the right of the adult to give, the adult is producing something, also a relation, whereas the improductive pleasure-seeking of the child is as if turning away from this 'sociality', becoming 'too natural'. The child does not give in return except in terms of (future) dependence.

The complexities of these familial relations cannot be subsumed under one heading, such as dependence, but it is an important aspect, especially since there is such a great preoccupation with 'reality' and 'independence'. ${ }^{12}$ Such problematical themes are more explicitly focused in kindergarten. There the child becomes more closely acquainted with the public character, and the vulnerability, of being an individual. 


\section{4}

\section{To be in a group: ideology and practice of kindergarten}

When a child in Linden is almost three years old his or her parents may apply to the kindergarten, which usually means that the mother goes up to the kindergarten and talks to Frau Meier, the head teacher, probably preferring to talk to the more good-natured Heike, the young 'second' teacher. Not all children start at the age of three. This partly depends on the need a mother has of having someone look after her child while she is working, although kindergarten is ideologically not motivated as an assistance for working mothers; it is meant to 'develop' the child. Being too eager to send one's child to kindergarten, almost letting it start before it is quite three, is a sign of not being a good mother, of trying to get rid of the child, of only thinking of herself. But not to send one's child at all to kindergarten, or waiting a long time is looked upon as a bit odd and isolationist. It is 'not good for the child', 'it won't have anyone to play with, and can't learn the nice things they learn in kindergarten'. So there is a small but distinct tension between the good and the bad side of motherhood in this respect, expressed by both mothers and teachers.

On entering her child the mother receives a small pamphlet on the general goals of kindergarten, implying adherence to goals of kindergartens in general. It begins by stating that it in no way is meant to replace the family, only offer help in the personal development of the child, the kindergarten being complementary to the family. It is taken for granted, and is respected, that parents have the primary responsibility for the child 
and wish to take the duty of rearing their child seriously. Early childhood is a time when children are extraordinarily receptive of influences from their surroundings, it is said, in this way games and other activities may acquire a new importance. The child will be prepared to learn new things, but only if it feels secure. Therefore it is the special task of the kindergarten to create an atmosphere of confidence and love together with the stimulation given through the different games and play materials. Along with that, life in this particular kindergarten is characterized by a Christian outlook, which is expressed in a kindegemässen Glaubens- und Gebetsleben, in einer ersten Glaubensvermittlung und Gewissensbildung und in der Einübung von Toleranz, Hilfsbereitschaft und Verständnis für den Mitmenschen ('child adapted life of belief and prayer, in an early transmission of belief and cultivation of the conscience, and in the training of tolerance, helpfulness, and understanding for one's fellow-beings').

As in so many other similar contexts, Christianity, belief in God, is phrased in moral terms of this kind. To be Christian, gut gläubig ('a good, real, believer') means, especially in child-rearing contexts, to be tolerant and helpful towards others, to be kind and forgiving, to do right. In an everyday context it is not Biblical knowledge which is emphasized, but the idealized good part of relations, the benevolent whole or collective of which the individual is to be (made) a part. It is relevant to recall here the ideas and values put forward by Fröbel and his followers, ideas about the unity of all things, within which individuality, and the true essence of one's being may develop (see above, Ch. 1), and for Fröbel this was also part of being a good Christian (although he was not Catholic). Fröbel used toys as representations of these aims, balls, cylinders, cubes, "to make the child aware of and grasp the unity of all mankind" (Bluhm 1971:104; cf. Allen 1986, Brockhaus 1971, H. Fröbel and Pfaehler 1982). ${ }^{1}$ Kindergarten is an aid in mastering the expectations of the coming life, also in more directly preparing the child for school, without the teaching of regular school subjects. The pamphlet tells the parents that both mind and body are engaged in this endeavor. The personality of the child is edified through a development of 'spiritual balance, strength of will, and independence'. Intelligence must also be enhanced through a variety of tasks which 'train perception, logical thinking, development of the usage of concepts'. Creativity is another quality which must be developed, and that is accomplished by 'finding own ideas and realizing them in play and creative activities such as drawing and 
painting, playing musical instruments, singing, making things of different materials'. But the person is a social being, so that it is necessary that the child be made 'capable of social contact', learn to show respect, solve conflicts with others adequately, understand rights and duties in relation to the Gemeinschaft.

The body is not mentioned as a prerequisite or an outcome of this striving, but the theme is closely related to it. A developed mind cannot live within an untended, disorderly body, is an underlying assumption, as I interpret it. The training of bodily movements through gymnastics and dexterity establishes 'security of movement' which coincides with the good person. An interesting aspect of this is the preoccupation with posture. To avoid bad posture, termed as 'damages of posture', Haltungsschäden, exercises are recommended, that is, Haltungserziehung ('posture education'). It is notable that the term Erziehung is used here. Mind and body are refractions of each other, as it were, and the mind may be reached through an ordering of the body.

The everyday routines do not simply correspond to the somewhat breathless goals of the pamphlet and the literature (cf. Hundertmarck 1978), but there are meaningful connections, and actually no points of disagreement, only perhaps a sense of goals not being attained. But they do lend activities an air of essentiality, at least as far as the teachers are concerned. Parents, and it is mainly mothers who are engaged in the problem, are not usually as explicit in their notions about what the goals of kindergarten are or should be. For them it is good for the children to be in kindergarten, they learn many nice things, make all kinds of schöne Sachen ('nice things'), what may also be called to basteln. They play, and learn things the teachers know. Mothers also point out that they get more things done at home if their small children spend some hours in kindergarten, but that is no goal, it is not mentioned as on a par with other goals, which are exclusively education-oriented. The parents do not mention grouporiented goals, their concern is with their individual child. It may be nice to learn to do things together, but their ambition isrelated to their child, not to a collectivity of children, as it is for the teachers.

Even if it is nice for children to go to kindergarten, it is not without a sense of ambivalence that mothers send their children there. A pressure is felt that one should send one's child to kindergarten, but this also means losing some control over one's family boundaries. Weaknesses and faults 
will be noted through the child. The teachers place themselves above the prerogatives of the family, as it seems to some parents. A certain distance is also upheld between most mothers and the teachers. Mothers never, or very seldom, enter the kindergarten during the day, which also protects the teachers' professional integrity. There is little talking either among the mothers and Omas or with the teachers as the children are left or picked up. By sending one's child to kindergarten, boundaries are endangered and so sometimes become more marked than otherwise.

The kindergarten in Linden serves the whole parish, which includes the two villages Kleinheim and Waldhof. Some families in Waldhof now prefer to send their children to the kindergarten in Brücken instead. This is taken as somewhat of an affront by the people of Linden, since Waldhof is part of the church parish and it is the church which runs the kindergarten. It is not because there are too few children in the kindergarten, on the contrary, but because Waldhof is here again siding with the political opponents of Linden, making Linden lose both some economic support and prestige. The church still has the main economic and administrative responsibility for the kindergarten, with some municipal support, even if it no longer is run by nuns. It is the Herr Pfarrer who is the 'boss', and parents and teachers consider that it is only through some candid pressure from the parents association that he will feel inclined to 'loosen the purse strings'. Many ironic and joking remarks are made about this state of affairs.

It took quite some persuasion to make him accept that a third kindergarten teacher be employed. There are 25-30 children in each group and Heike and Frau Meier, the teachers, felt there was need for at least one more teacher. The children are of different ages and are engaged in different activities, which one person cannot supervise alone all the time. Finally young Hildegaard, who was from Kleinheim, was employed during my stay.

As compared to the school, the kindergarten is more of a local concern in its organization. It engages parents in a variety of activities which do not occur to the same extent in relation to school. There are parent council meetings, evenings for hobby work, kindergarten spring feasts, Christmas bazaars and feasts. Parents are also expected to participate voluntarily in certain activities - the men in helping out with the 
construction of the playground and the women in baking and basteln for bazaars and feasts. When activities are organized in order to save or raise money, the Pfarrer becomes more directly engaged. The construction of the playground - setting up a fence around it, evening out the ground, erecting see-saws and the like - was a cost he was insistent on saving, the church could not afford it, and it was only right, he said, that the men help out with work, as they did, so many of them, with the new Turnhalle, the sports hall. 'It is not only the sports association which should be helped out with free manpower, the church is also entitled to it', was his not ineffective command.

\section{A day in kindergarten}

At about a quarter past eight in the morning Frau Kellermann takes her youngest child, Peter, by the hand, after having seen to it that his hands and fingernails are clean, his mouth wiped after breakfast, and walks off with him up the hill to the kindergarten. Peter calls good-bye to Oma and adjusts his little bag hanging over his shoulder, asks his mother if she has put something good to eat in it. Bread with chocolate spread and a candy bar - to his satisfaction. His father has already taken the car to work, he is employed in an office in a town in Hesse. His two sisters have taken the school bus to Steingrund and Städten, respectively.

Frau Kellermann seems strained when she talks to Peter, as if she were in a hurry. It turns out that Peter has been unhappy, complaining about kindergarten, that he doesn't want to go, his stomach hurts. She knows that he worries about being in kindergarten, but she just cannot get anything done at home and in the shop if he is hanging around her all the time, and the Oma gets tired of having him jump about all over the place. Anyway, he does learn a lot in kindergarten, Frau Kellermann says, he brings home all kinds of things he has made. It was much worse in the beginning, last year. He would cry and want to go home. Frau Meier locked the front door so that he could not get out, that was just plain silly of her. She does have an abrupt way with children, kind of hard. She's unmarried so she doesn't have any children of her own, she can't understand them. The other two teachers, Heike and Hildegaard, are nicer, really, more fun, Peter likes them. But Frau Meier is a very good pedagogue, and that is quite important, of course. Peter is always wishing that it is 
Saturday, the poor thing. She laughs a little as she tells me this while we are walking together.

The kindergarten lies close to the school. It is newly built by a local architect, who is also a fairly influential member of the council - 'which was what got him the job', was a comment made with some sarcasm by one or other parent. It is a large, open house with a great hall in the center, flanked by the two group rooms, cloakrooms and bathrooms. The big hall is used as a gym, but also as an assembly room when there is need of more space for an activity or a common celebration, or when mothers gather some evenings to prepare a Christmas bazaar. The building is beautiful, no one denies that, but the teachers complain that the plan is more impressive than practical. Herr Rothburg, the architect, is obviously not so aware of all the practical needs of a kindergarten. Of course it is much better than the old kindergarten which lay down the road. Many years ago the kindergarten was run by the few nuns who lived in Linden. I was shown photographs of middle aged Lindeners as small children staring into the camera as they stand on the steps of the old kindergarten.

Peter and his mother arrive just a few minutes after the others have gone inside, mothers and Omas leave the premises, some by car. There is not much talking among them, everyone has things to do. Frau Kellermann gives Peter a light kiss, tells him to behave and not get dirty if they go outside later on. He does not protest, just fidgets a little, wants to ask her something before she leaves. She shoves him gently inside and says good-bye.

The cloakroom is full of children hanging up jackets, taking off their shoes and putting on slippers. They hang their snack bags on a special rack. Heike stands in the doorway to the room, talking to those nearest her, kidding them. Seeing that Holger just threw his coat on the floor, being more busy with teasing and chasing some other little boy, she calls out to him to stop it right away, hang up his things and get himself inside, quickly. The children go into the room, not in any particular order, some chatting with each other, others by themselves.

The main room, where the children spend most of their time, is furnished with small-sized wooden chairs and tables, around which four or five children can sit and engage in drawing, cutting out figures from colored paper, making clay figures, playing a game - Memory was at the time very popular - laying jig-saw puzzles, putting plastic Nobbers (kind of soft 
Lego-like pieces) together into various constructions. The materials they use are kept in boxes and on shelves in the room, crayons and scissors are individual belongings, marked with each child's name. On the walls hang drawings the children have made, and other pictures and decorations.

One table with room for six children is the 'tea table', it is only used when eating the morning snack. It looks like the other tables, but is made distinct by this particular function. In one corner there is a sink and a cupboard with cups and saucers used for the herb tea, which the teachers prepare in the kitchen. The two corners on the opposite side of the room are partitioned off with low shelves and arranged for particular play. In one, die Puppenecke ('doll corner'), there are big pillows and a mattress to sit on, a big box with clothes and shoes for dressing up, dolls, dishes and pots and pans. In the other corner, die Bauecke ('building corner'), there are wooden building blocks, a big set of wooden trains and tracks, and plastic Meccano.

In these 'corners' the children may only play four at a time and the principle is 'first come, first served'. Leaving the corner usually means losing one's place. Often some children will stand just outside the corner and watch what is going on, make comments, annoy, or just wait for a chance to go in. But before the chance comes Heike, or Frau Meier in her section, may summon all or some of the children for tea or Beschäftigung ('occupation/organized activity'). Beschäftigung is the most pedagogically goaloriented activity in kindergarten. The children will be given some explicit task, they will be taught certain facts, for example, about the seasons of the year, different adult occupations, differences between town and village. These activities recur every day, each week or month having a specific theme. The children are divided into smaller groups categorized in terms of age - the small ones, the middle ones, the big ones. Expectations on them vary accordingly, that is, their achievements are judged according to more or less pronounced ideas about what children of different ages can be expected to accomplish. Ideas about achievement refer to standards learnt at the pedagogical schools, and are complemented by an assessment of the individual child, its 'character' and 'intelligence', and the kind of family it belongs to. Like other notions of what constitutes the essentials of a particular child, they are situationally influenced, but the situation itself may not be a part of the explanation. That is, a child's accomplishments are not understood as related to the situation at hand, even though 
this situation influences the teachers perception of the child, as I understand it.

Heike or Frau Meier will take a small group into the other room adjacent to the main room for the Beschäftigung, leaving the rest of the children to themselves, or else Hildegaard will take over. The door to the small room is closed, otherwise the noise from the other children (which can be deafening) will disturb too much. Or else they will come in and want to participate. It just does not work, Heike says, they can manage on their own, they just have to learn to do that and not come running as soon as they wish. If there is fighting in the big room, which there is off and on, Heike will not let herself be bothered by it unless it gets completely out of hand, which she assumes it has if they are screaming and running around too loudly and wildly. She will then go in and check, reprimand them, and tell them to stop.

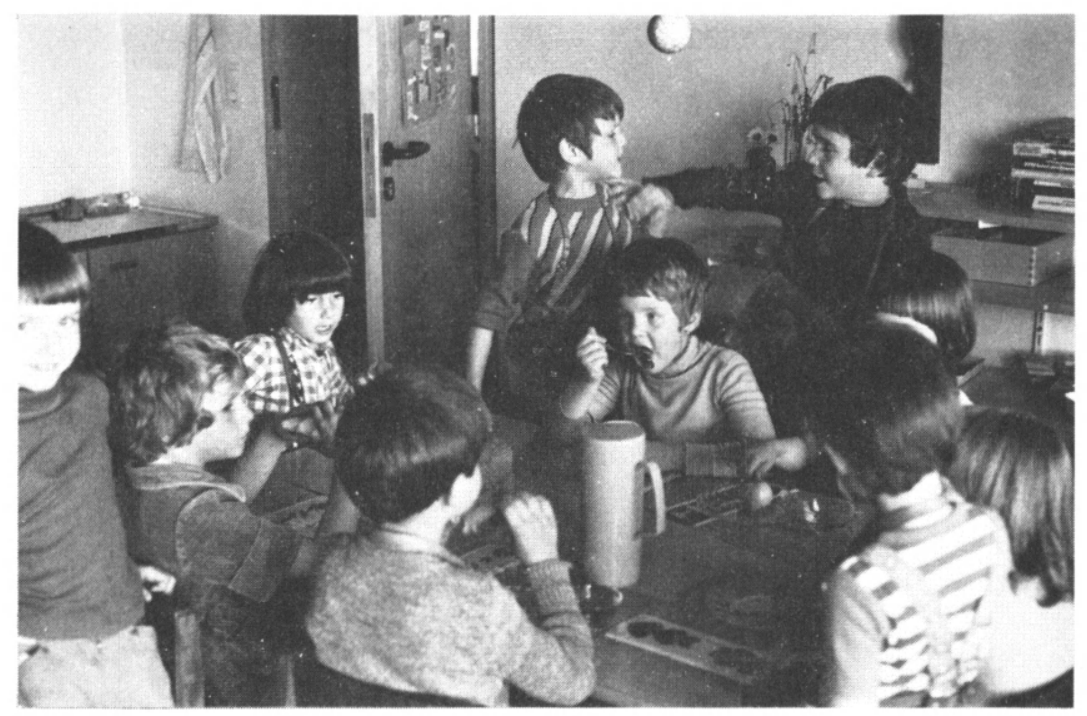

Essenzeit, tea time in kindergarten.

Around ten o'clock in the morning Heike, and Frau Meier in her section, call out to the children that it is time for tea, Essenzeit! ('time to eat'), after having told the two or three children whose turn it is to set the 
table, and do the dishes afterwards, to get the table ready while she goes to the kitchen to get the pitcher of tea. Many of the children rush into the cloak room to get their bags, pushing and colliding in the doorway, scrambling to get a seat at the table. Since only six children at a time can sit at the table there are always children standing close behind those sitting and as soon as any of them gets up there is a new round of shoving to get the seat. Some of the children are not as eager to have their snack and continue to play while the others eat. A child who has been longing to play in the Puppenecke or the Bauecke but has been warded off because wir sind schon vier drin'! ('we're already four in here!'), may take the chance when the others get out to have their snack. Sooner or later they must, for no one is allowed to skip eating all together. None of the teachers would dare let a child go home to its mother with the snack uneaten. It is a bad teacher who cannot see to it that a child is fed, at the same time ignoring the good things a mother gives her child (actually mothers also worrying that the food they send with their child will not appear to be enough in quantity and quality). Some other child may hold out as long as possible, so that it will not lose its place in the Ecke. Or else, someone will sit at the table and call out to the newcomer in the corner that the place is already taken, an admonishment which is either respected or ignored. By the time everyone has had tea there is not much time left before going home, except mainly for aufräumen, a central activity in kindergarten, that is, tidying and cleaning up. ${ }^{2}$

Before getting jackets and shoes on to go home, the children are gathered in a ring or stand before the crucifix and say a prayer in unison, thanking for this day. When everyone is ready to leave, and not before, they are let out to their waiting mothers, Omas or sisters.

An impression is given in the kindergarten of constant movement and activity, a kind of 'milling around'. The children are often on the move, walking around the room, chasing one another, perhaps fighting, getting some material or game they need, or going to the teacher to tell on one of the others. At the same time, there is a sense of waiting. Someone is always waiting for something - waiting to get a chance to play in one of the 'corners', waiting to get one's turn to eat, waiting for a chance to use some new material, waiting for a game to be finished, waiting to get the teacher's attention. The teacher, on the other hand, is often sitting at her desk, placed at one end of the room, checking some of the children's 
drawings or other tasks, writing a report, but also cutting and pasting figures and the like as the children do. But she will also walk around in the room at times, checking and commenting the children's games or tasks.

Through the different activities during the day and the instructions given by the teacher, children are meant to learn to concentrate and be patient - learn to cut with the scissors and not give up as soon as it does not work; learn to hold pencils and crayons correctly between thumb and forefinger; learn to listen and follow instructions, but also develop the use of the imagination. The child is formed through instruction. This requires the competent and good other, which cannot be found only within the home. For the child the kindergarten teacher should become the second Bezugsperson ('person of reference'), and a behavioral model for the child.

In the ideology of kindergarten the group is an essential social unit. It is the frame within which learning can be accomplished and order attained. A child must get used to being in a group, learn to work and play in a group, and not just think of itself. A group implies notions about unity, in terms of undifferentiatedness, and in modern pedagogics it is a cherished conception. The idea is that in a group children will learn social competence and curb their egotistical tendencies, which are then of a 'natural' kind and potentially evil and disruptive of the social order. But the difficulty is that a group is considered as such only when it is consciously constructed and organized by someone else. The teachers hardly consider themselves as belonging to this group, for example, and in other situations social life is considered as an individual endeavor. The group in which a child is immersed does not move as one body, but rather each individual is subordinated a higher order and it is this order that is to be considered. The kind of group Heike, for example, is talking about is one which rewards submission and conformity and the preparedness to prove oneself individually capable and unique. Within this group learning takes place, the child is thought to acquire the right traits and capacities. It is a process which to some extent is thought of as terminable, losing relevance when adulthood has been reached. It is a process which will make the child lebensfähig ('fit for living'), and from this point of view, it is not directed at adults.

The above description of a kindergarten day is not meant to be just an uncommented setting. There are several more or less observable 'key themes', 
those of lernen, Ordnung, Selbständigkeit embedded here, which I shall return to as this chapter proceeds. That is, themes which have an ideological import relating to notions about what a child is and how it should be molded into a good person. ${ }^{3}$

\section{The newcomer}

Little Otto is quite relieved to go home. He was left in kindergarten by his mother a few hours earlier. It is the fourth time he is there and he has spent much of his time crying and anxiously tagging along Heike. She has told him, consolingly, that his mother will come for him soon. She tries to encourage him to stop crying by making him aware of the fact that the other children are not crying. She tries to interest him in a game some of the other children are playing in the Puppenecke, but he has remained standing outside, watching, and the children do not bother about him. $\mathrm{He}$ walks around for a while, starts crying again, saying he wants to go Heim ('home'). Then some of the older children try to comfort him, a little girl who knows him puts her arm around him, they pat him and try to cheer him up, but, alas, with only short-lived success.

For the small newcomers to kindergarten there is no prescribed or ritualized form of acclimatization. Before the age of three they are not allowed to begin, but the acclimatization actually means that the children start attending the kindergarten some months before they have turned three, but spend less time there than the other children. It does not imply that the mothers stay with their children for a while in the beginning. They will go in with them, even enter the main room, which mothers otherwise never do, but then leave very shortly afterwards. The teachers are not very keen on having mothers around in kindergarten, it is not forbidden, but they will under no circumstances be encouraged to stay on - 'what would we do if there were mothers all over the place all the time, it just wouldn't work!'

Kindergarten means a separation of the child from the parental home, die Ablösung vom Elternhaus ('the separation from the parental house/family'). In the preceeding chapter I described the ambivalence with which this process seems to be perceived by the mothers. The kindergarten teachers think of it as something that should come more or less of itself, as Heike says. She means that often it is the mothers who have the 
greatest difficulty in letting their child loose, while the child wants to come. That most children cry in the beginning when they start kindergarten is nothing unusual, but for how long will depend on the child, how independent it is, and that depends on the Erziehung in the home.

The important thing is that a child 'must get used to how life is', there is no point in trying to avoid what must come anyway, or what is deemed necessary to adjust to, like separating oneself from home. The teachers find it troublesome with mothers who cling to their children, incapable or unwilling to separate, as they are prone to interpret most mothers. The show of dependence between mother and child is not good, and should be discouraged. The same goes for children who are taken to be too dependent on each other or on some teacher. They should be separated. This stands in an interesting relation to the closeness and even dependency which is manifested particularly between grown daughters and their mothers, and which is hailed as something morally good, as we saw earlier.

I asked Hildegaard one day how little Norbert was getting along, he started kindergarten just the day before and cried a long time after his mother had gone. 'Oh, he screamed and screamed this morning, so finally Heike locked him up in the work room. He pounded on the door and she told him she would let him out when he had calmed down and stopped screaming and pounding'. After a while Frau Meier had come over and scolded Norbert, and then everything was all right. 'He's been good since', she said with her young girl's smile. 'He's so spoiled, that child, from home. His sister is seventeen and he's only three so I guess he's just used to always being at the center of everyone's attention. Of course, yesterday he was here all morning and then all afternoon, that's too long in the beginning. It wasn't right of his mother to do that, Heike is going to talk to her about it'. Although this may explain his excessive screaming, it does not really excuse it. A child's excessive demands are not to be excused, but remedied in one way or another.

In contrast to Norbert, who does not stop crying and screaming on other days, Maria just cries a little bit, more to herself, as she wanders about the room. And Klaus spends most of his time, still after six weeks in kindergarten, lying on the floor, refusing to play with anyone. Actually, Norbert is the easiest to cope with for the teachers - he is disturbing and can be dealt with accordingly, that is, cut off from the others, radically 
separated until he is prepared to accept his predicament. They tell him that he can come out when he doesn't need to scream anymore - 'and he understands that really, because he doesn't have anything to scream about, he'll see his mother soon. He is quite simply a child who hasn't run into any limitations before. It is high time he learn'.

To Maria and Klaus there is not much to say, or do. They do not disturb, and the teachers do not seem to find any means to handle their more soundless agony. Frau Meier says she has asked Klaus's mother if he is tired since he lies on the floor so much, but no, that couldn't be it. 'So what can it be, there is something he does not like here, but what?' Klaus is observed but not made into a partner in search for clues about his experiences. Maria and Klaus are left pretty much alone, sometimes asked to participate in some game or other which the teacher organizes, but they are not pushed. It is expected that they will become more participatory with time. Certain activities, like the Beschäftigungen, are compulsory, as are the gymnastics, which will pull them into the group.

The kind of behavior which Norbert displays is, in a broader cultural context, seen as more normal or natural for a small child than that of Maria and Klaus, even though his behavior is punished or restrained in one way or another, perhaps through criticism or ridicule and teasing. To be quiet and withdrawn is 'not natural'. Children are impulsive and full of energy and this must manifest itself even negatively. To be 'not natural' is in a sense to place oneself out of reach of the pedagogical control, standing 'outside', as if in a critical position.

The older children, those who have been attending kindergarten for some time, and especially the girls, will quite often show the newcomers kindness. This does not imply that Frau Maier and Heike and Hildegaard will not also treat the children with some compassion, but their actions are imbued with a pedagogical ideology which the children do not comprehend (other than indirectly through such mediums as tell-taling, to which I shall return below). Pedagogics demands results, of a predicted kind, which hampers compassion, since expressing compassion does not necessarily give wanted or foreseeable resluts, and can even complicate matters.

The older girls will, for example, start engaging Klaus in a game, London bridge, perhaps; take Maria with them into the Puppenecke, let her play baby or dog. But when Heike tells Sandra that she is a baby because she refuses to participate in the gymnastics, then it is tempting for the 
other children to fall into this line of thought, perhaps thankful that they are not babies, and tease Sandra, or tell on her to the others. This does not necessarily lead to Sandra being excluded from their games, they almost all of them have some experience of like predicaments. There is arguing and tell-taling, there is fighting, particularly among the boys, but the flow of activities and tasks to be completed keeps the children on the move, so to speak.

When Edit started coming to kindergarten, she was almost three years old and came under the protection of Tina practically from the beginning. Tina is two years older than Edit, a bit lonely as it seems, and Edit is a distant relative of hers, so everything is just made for the two of them to keep together. Edit has become very dependent on Tina being there when she comes to kindergarten in the morning. Edit's mother is also quite anxious about her being there, relieved to have someone explicitly taking care of her, since Edit often seems unhappy about being in kindergarten, starting to wet her pants which she has not done before (not so uncommon among the small newcomers), crying without any apparent reason.

Frau Meier is less pleased about this arrangement. She considers that Edit becomes too dependent on Tina. 'It is not good at all, she lets Tina do everything for her, decide everything. Tina even makes Edit's drawings!' After a few months the two of them still kept quite close together, but it did not seem as if it was detrimental for Edit's ability to make other friends, that is, associate with the other children and participate in the activities prescribed. But it is fairly obvious that she will not accept kindergarten without Tina and Tina enjoys her new position and her second cousin's devotion or dependence.

None of the teachers actually appreciate the relationship which has developed between Tina and Edit. Had Frau Meier found it possible, as she has with children less passionate than these two little girls, she would have placed them in different groups, that is, separated them. The little pact these two girls have established seems as if it were a counter-force to the unity the teachers are striving to maintain control over.

Hans does not have a Tina to rely on. He has been a very unhappy boy for weeks and weeks and soon developed the need to be near Hildegaard, whom he knows a little from before. If he is allowed to be with her it is all right, but when she leaves the room he begins to cry sadly. Hilde- 
gaard finds this very tiresome, although she obviously likes the little boy and feels sorry for him, letting him be near her when she is around. He will sit on a little chair next to her, or take her hand as he tags along after her. But she dislikes that his mother complained, as she puts it, and asked her that she care more about him - an unusual request. Hildegaard feels that she cannot do any more, not with all these children to look after. An aspect she does not mention but which must have influenced her is Frau Meier's active disapproval of such a show of dependency, and her demand on Hildegaard to fulfil her various duties as assistant to both herself and Heike. But Hildegaard also voices the commonly held notion in Linden that children should not make too great demands on attention, that they must adjust to given situations. From this viewpoint, Hans is spoiled. Since his brother is many years older than he, he is virtually an only child, and only children are spoiled. As Frau Meier says, 'Hans doesn't cry because he is afraid (he kept saying that he was afraid that his mother would never come back to him), but because he is zornig ('angry'). He doesn't get his way, which he always does at home since he is the youngest'.

Most newcomers find themselves in an unknown position and have very few means of making the whole ordeal meaningful, they do not have access to the competence and knowledge of the teacher or parent, nor that of the older children who have already gone through this phase. The pain is perhaps greatest because it seems somehow limitless. Where are the boundaries of this phase? The child cannot know and there are few attempts to help it find out. The child must take matters into its own hands - by screaming and crying, by finding a close ally, by retreating into itself, by turning to one of the teachers.

Independence is a higly valued trait or capacity which develops through the Erziehung, through the learning of Ordnung, actually. It is assumed by the teachers that the more independent a child is, the easier it will accomodate to the routines of kindergarten. Dependence is not really the exact opposite of independence, Selbständigkeit. Dependence, Abhängigkeit, refers also to an emotional bond between in this case primarily mother and child. It is assumed that this relationship is strong and that mothers are an obstacle for its dissolution, which is not good for the child. A dependent child is rather a spoiled child, verwöhnt, which then appears to be taken as the opposite of selbständig. An independent child is one who knows the order that reigns and can manage the routines without having to ask what 
to do. Independence is then not primarily emotionally based, rather freed from emotion. As I see it, dependence is a blurring of boundaries. The child, through its manifestations of unhappiness, or 'stubbornness', seems to fuse home and kindergarten, but in Linden thinking these are to be kept apart as complementary but separate entities of a whole.

\section{Mastering reality and being creative}

Hildegaard takes about ten of the children into the work-room. They are all given a sheet of paper with a picture on it showing four children of different ages, three are playing together, one is left outside. Hildegaard talks to the children, to a large extent in the form of questions (cf. Heath 1983) - what do you see? what is happening? what are the children doing? 'The children are building something. One boy isn't allowed to join them', Sabine says. What happens to him then? 'He becomes unhappy', Hannah adds. Were you ever unhappy? Has this happened to you? And the children tell Hildegaard about situations they have experienced which resemble the 'story' in the picture, and they all refer to the boy who is not allowed to play. The smallest girl in the picture is seen asking the boy to join them and as a result the four children are seen playing together and smiling happily.

The pictures are not ordered in the right sequence, which is the children's task to accomplish. Difficulties arise for them, but Hildegaard tells them that 'now it is your task, cut them all out and paste them in the right order on the piece of paper I gave you. No, Thomas, I'm not going to tell you any more, do as you've heard us talk about it. Look at the pictures! Think!'. 'Fräulein, Fräulein, look! Is this right?' The children are calling to Hildegaard. Thomas keeps staring at his sheet of paper, seemingly at a complete loss. After quite a while it dawns on him and he orders the pictures correctly and is greatly relieved. But he knows that Hildegaard would not scold him or shame him like Frau Meier, so he looks happier than he otherwise does during the Beschäftigungen.

During the day there is an oscillation. between tutored activities and 'free play'. The Beschäftigung, the most organized tutored activity, always with some particular practical, intellectual aim, is the main arena for teaching and learning. During the year each child should accomplish certain tasks, for example, make assigned drawings - large fish with scales, an Easter 
egg, a picture of a village, a town, pasted autumn leaves on a piece of paper, and so on. Each child has its own folder over which the teacher takes responsibility, storing all the different paper work in it. At the end of the spring semester each child receives his or her folder to take home and show the parents what it has accomplished - which in turn shows what the kindergarten teachers are worth. The Beschäftigung is meant to teach the children certain aspects of the workings of the society they live in, its practices and its moral code, and they are to learn about nature.

For many of the activities the children work within their age group, usually in a separate room next to the main room, sometimes out in the big hall depending on what is to be done. They spend perhaps half an hour or longer for each activity.

The big ones are gathered in the hall. They sit in a circle on small mats laid out on the floor. Frau Meier sits in front of them and shows them a large collage they have all contributed in making. It represents a village, their village of Linden. They have drawn houses, buildings, figures, cut them out and pasted them on this large sheet. They all point to their 'own' houses.

'Now we know what a village is, but everyone isn't always in the village. And all of the houses are not for living. Which means that people are away working. What does papa do? He works! And who is at home? Mama! the children call out in answer to Frau Meier's questions. But die Mama is not always at home, Frau Meier reminds them, there are also quite a few mothers who are employed. But this time they are going to talk about what der Papa does.

Der Papa geht fort, er geht schaffe', as the children say ('Daddy goes off, he goes workin'). Sigrid's father works for the Red Cross, in Hesse. Beate's father is house painter, Inge's is a mechanic, Ernst's father arbeitet ('works') - he is Kaufmann ('business man'). He is not an Arbeiter (worker, laborer) who schafft ('makes, produces', that is works). Franz's father writes, as he expresses it, employed in an insurance company. Hannah's father is a garbage collector. The children make the distinctions between different kinds of work by using the words which denote social class in Linden - the distinctions between being employed, a white-collar worker, and being a laborer, a blue-collar worker.

Then they are all to look at different pictures showing different kinds of jobs - a baker, a tailor, a carpenter, and so on. The children 
consider all larger buildings as factories, industries - 'but everything isn't done in a factory', Frau Meier explains. Neither are there only artisans in a village or town, there are also others, like Franz's father - he writes, sits at a desk in an office. 'My father writes, too', Anja calls out. 'What kinds of jobs are there in Linden?' Frau Meier asks them. They start off with the baker and identify all the different phases in the baking process, naming ingredients and utensils.

The teachers are fairly free to decide which themes to take up, but the work as a whole must be sanctioned by the church and the municipal council. The teachers have their education and are summoned to seminars off and on in the neighboring city to discuss the on-going work, difficulties which arise. Also kindergarten teachers from neighboring villages will meet once in a while to plan their activities. In this way, kindergarten differs somewhat from school. They are both part of the same educational ideology, but the school stands under stricter control from the local, and state, educational board.

About two times a month the kindergarten teachers in Linden meet with other kindergarten teachers, particularly with those from the neighboring village of Altheim, to plan the activities for the next few weeks. They sit around one of the children's tables to drink coffee and eat Kuchen, cake, together and talk about their work, complain about some bad play material. Which themes for the Beschäftigungen the coming two weeks? They look through some instruction brochures - which can be ordered from town, but they must pay for them with their own money - 'Der Pfarrer doesn't consider it important enough to spend money on things like that'.

Life is not only about work, however important this is to people in Linden. Life is also closely connected with Christian belief, which the children should be made aware of, even if the practicing of 'religion' in kindergarten, and in the Beschäftigungen particularly, is not overwhelming. The ordinary day is not obviously oriented towards religious practices, but the moral code is recognized as, and expected to be, Christian, and as such make the children familiar with the Catholic Church. Songs are learned, the church calender is followed. Christmas, Easter, and Pentecost are clearly religious holidays and prepared and talked about in such terms, as matters of 'belief' and 'being Christian'. The stories told or read to the children have a moral intention which is the message of the Christian. Doing good, 
being fair, righteous and feeling empathy with the plights of others, all this is interpreted as primarily Christian values and practices and so human, universal. So the good person is the Christian person.

Kindergarten teachers feel that parents would not like religion to be left out altogether in kindergarten. As the young head teacher in the Altheim kindergarten says, parents would be much more inclined to criticize her work if she were to leave out the religiöse Führung ('the religious tutoring'). Yet she herself feels very uncertain, finds it difficult to know what the right thing to say is. She is certainly aware of the strong tendency adults, parents, have of denying doubt, especially in religious-moral questions, in front of their children.

This head teacher belongs more to the category of "modern believers' who see the Bible and the teachings of the church as a store of historically debatable facts and moral values and who may speak of certain ritual behavior or religious ideas as 'symbolic', that is, 'not true' in a 'historically factual' sense, whereas this is not a term commonly used in relation to the matter of religious beliefs. For this teacher 'religion' (in terms of belief) is an individual concern, a matter of individual 'inward searching'. She does not feel that she can say anything very convincing about it to the children. She can teach them songs and prayers, as the parents may wish, but she has difficulty answering their questions. She thinks that they ask such difficult questions, which she cannot answer, because it is as if it were not the children but their parents who were asking - and what can she say then when a child wonders where God sleeps, or where hell is. Such questions don't have any answer, she exclaims, and this is to her because they have no 'reality', and they lack symbolic value. Heike is not as concerned about such problems, although they are about the same age. She herself goes to church regularly, and is not bothered about their 'silly notions'. She laughs at the children, teases them, but does not worry much about things like that.

Frau Meier, on the other hand, is disturbed by how seldom some children are taken to church by their parents. She herself has a very churchoriented background. Yet she is much less disturbed by the 'childish' stories about God and his whereabouts than is the head teacher of Altheim. She is so well rooted in Catholicism and the order of the church that such matters are trivial and do not encroach on her own set of ideas. What does bother her is that the children know far too little about the order of ritual 
in the church. In these respects, she resembles the ways of reasoning of the Pfarrer .

A few times a semester the children are taken to Children's Mass together with the teachers and some of the mothers. It is soon after kindergarten has started in the fall; right before Christmas, Easter, and All Saint's Day. Frau Meier talks to the children about the Children's Mass she had taken them to the other day. Who was there at Mass yesterday? she asks them. I was! I was!

What was different yesterday in comparison with the Children's Mass earlier? Well, there was stuff to be poured, says Iris. That's right - what? Water. And wine, Peter adds. And what else? They got one of those tablets, Tina says. Yes, what was it? It was a consecrated wafer, the Host, Frau Meier informs them. For the mothers, Sabine comments. I got one, too, in my hand, Frau Meier tells them. Some want it to be placed on the tongue, others in their hand. But Erstkommunionkinder ('first communionchildren'), receive it on their tongues, so that they shall know what it means, what it is like. But you children didn't get one, you are still too small. What must you first do to be able to take part of the Eucharist? Take Erstkommunion! Yes, you have to learn what it is all about. It's not just ordinary bread, it must be transformed, and only a priest can do that, transform it into Jesu Leib und Blut ('Body and Blood of Christ'). Yesterday it was a Mass, a Children's Mass, and only a priest can hold Mass. Earlier we were at a Low Mass where there is no communion.

From this little lesson about a small, but central, part of the ritual order of the church, Frau Meier changes to a different topic, but, as she points out to them, it also has to do with religion. She hangs up a brightly colored picture on the wall which shows how the rich and the poor live. What is this? A house. A house?! A castle! That's right, a castle. You can drink coffee in there! Hilda calls out and Frau Meier does not answer. She tells them that a castle like that has many rooms, that kings and princes lived in such castles a long time ago. There is a swimming pool, great lawns, horses, and a wall surrounds the whole area. What does that mean? she asks them and answers herself that it is meant to show that everything inside the wall belongs to the owner of the house. What do you call people who live like that? Do they have little or much money? Much! they call out. And what is that called? To be rich!

There is a street outside the wall with cars, buses and below that - 
what? A car cemetery! Yes, and it is not - what? Schön! ('nice'). That's right, it is not schön. What is all this down here, she asks as she points to the lowest part of the picture. Houses. Children. They're real houses, Thomas points out (which the castle is not). I see a cat, Hilda calls, seemingly pleased. Is there any grass here, Frau Meier wonders. No. Does it look schön where all these houses are? No! It's dirty! Do they also have a lot of money? No, only a little. They are poor, yes, says Frau Meier. A man is seen standing outside washing himself in a tub. Where do you wash yourself at home? Under the water tap, in the bathroom. And you are not poor people, right? There is something in between rich and poor - the people of Linden are not rich, but not poor, either.

The children discover mice in the picture. We have mice in our cellar, Sabine says. My daddy puts out rat poison, Walter informs them. And my daddy has rat traps! Thomas calls out. And they practically all start off on a discussion about this intriguing subject. Frau Meier interrupts them and brings them back to the main issue of poverty and richness. And she sums up by saying that they are not poor, mice enter cellars and barns in the autumn and as they are, after all, living in the countryside they are bound to have one or two mice in their houses.

Poverty and richness are related to destiny as well as to one's own doings. The enterprising individual is certainly admired, and it is highly valued to do a good job, which can be deduced from a person's comfortable material result. But extremes are not good. One should have enough but having too much is a sign of greed and unfairness. One should be satisfied with what one has and not always be grasping after more. So there is a kind of Christian humility and gratitude which the children are confronted with, implicitly, as they hear the directed questions of Frau Meier. Gratitude for being normal, but also compassion with those who are not, that is, those who are poor. There is a wordless social critique of those who seem excessively rich, they are actually not really normal either because their wealth shows their lack of compassion. Instead of sharing with the poor, giving them some space on their lawns, helping them build nice bathrooms, they build a wall separating themselves from them. This implicit allusion to fairness and social responsibility is part of a more explicit social-political concern in Christian conceptualizations which is part of the ideology of the 'social Christianity' of the Catholic Worker's Association (the $K A B$ ) (see ch.6, note 5). 
It is common in both kindergarten and school that religion and the religiously formulated problems are presented in terms of good and evil (bad), which is often conceptualized as moderation and excessiveness respectively. This is experientially and situationally formulated, that is, situations are presented, both specific and generalizing - which is the genius of pedagogics - so that any child is assumed to be able to identify itself with one or the other of the actors without making it so explicit that a child will feel pointed at. There is a demonstration of anonymity and a preordained matrix of interpretations. One's thoughts are subordinated to a whole which recognizes but like individuals.

Teachers are, through the story, encouraged to give the moral clue and the children to associate to experiences like those presented in the text. Sometimes these are biblical, but more often happenings distilled from everyday life, which all can be related to presumed universal values of sharing, responsibility of individual and group, the possibility of identification with all others. All these situations are socially and politically unspecific as to a wider context, and it is mainly from such 'models' that children will be encouraged to consider their own life situations, whose main worth is didactic of a Christian ethos. The individual and the situation are made unspecific and only the ideology is specified.

The Beschäftigungen are the pedagogical center in kindergarten, even if everything in kindergarten can be subsumed under the ideology of lernen. The notion of learning is basically one which presumes explicit teaching. Learning which comes from the realm outside teaching is not as 'real' as that which comes from being taught. Children are more prone to take after bad habits than good ones if they are not taught and led into that which is right and good. So, the children in kindergarten are constantly being made aware of the didactic value of their activities.

A child who does not learn what is being taught is considered to be stubborn or inattentive or unintelligent, or all three. The situation at hand, the actors involved, are not used as terms of reference to any degree when a child cannot learn something which is being taught, that is, makes mistakes, misunderstands, is extremely slow, etc. Rather, it is the child who is at fault, and in extension the child's family, or mother. Learning, which presumes teaching, builds on, creates and recreates a relationship between the subordinate and the superordinate. It is not for the superordinate to 
explain failure of learning as having to do with this relationship in terms of a relationship. The superordinate, as such, is not a part of the situation, whereas the subordinate is not able to disengage itself from the situation to the same extent. It is not for the superordinate to understand, that is, identify with, the subordinate, but rather the other way round.

Frau Meier is intent on teaching the children, she wants them to classify and order experiences, know what things are called. She uses her educational ambitions both in promoting the children's capacities and as a form of punishment. Learning is imbued with moral values of how things should be, how one should act in different situations - the showing of politeness, diligence, attentiveness, 'good sense'.

In this educational endeavor Hildegaard and Heike, like the teachers in kindergartens in the neighboring villages, resemble Frau Meier, although she is the strictest of them in enforcing the education. This is something they notice, gossip about, and criticize behind her back - also because she is demanding of them. But they do understand each other and Frau Meier is considered to be a 'good pedagogue'. She is the most ambitious, and in this sense dedicated, of the kindergarten teachers - but also the one who seems to be most at odds with herself, and with the people in her surroundings, even with the educational methods and ideology she supports. Her own childhood was both hard and traumatic, as she describes it. And she is an outsider to Linden, having lived there only a few years. She is an unmarried woman, not so well liked, perhaps, but respected. She has ambitions to learn about 'modern pedagogics', she has 'high ideals' and is constantly disappointed and provoked by the world around her which does not live up to her demands.

She speaks about the children and kindergarten and her own childhood as if she were taking revenge for her own feeling of misery. As the kindergarten functions, its educational ideology, it becomes possible, as I see it, to canalize such feelings into the relation with the children, and it will not be considered as anything but Erziehung, and the need for Erziehung can never be denied.

For a young woman like Heike, on the other hand, not yet married, with both kin and friends in Linden, and with a more pleasant and easygoing family background (in accordance with the world of Linden), the rules of order and obedience, achievement, cleanliness, punishment and praise are less controversial and emotionally charged than for Frau Meier. 
Heike need not reflect over life in Linden as something problematical in the sense of standing outside it, she feels that she is part of it. Heike is considered nice and friendly, she can enjoy a good laugh, and she can schön basteln with the children. No one would question her methods of teaching, of punishing or praising, although they to a large extent resemble those of Frau Meier, which are sometimes criticized.

A good teacher is one who can viel und schön basteln ('make many and beautiful things'), an ability which is admired both by mothers and by the teachers. If the children bring home a lot of things they have made in kindergarten this is to many mothers a sign, the sign, that kindergarten functions well, that the teachers are good, that the children learn. They get their money's worth - an important aspect in the valuation of social life among Linden people.

Basteln means making different kinds of decorations, it is being handy with various materials, making figures out of clothes-pegs, cardboard; using strings, silk paper, paste, crayons, pearls, and so on. Drawing pictures with the help of templates which are laid on paper and filled out with crayon is very popular, especially among the girls. The teachers themselves enjoy this very much too, although they are aware that it is criticized at seminars for inhibiting the development of imagination and creativity. Heike, in particular, is very keen on basteln and she will off and on sit at her desk and make something while a group of children stand around her and watch, admiring and praising her dexterity and the 'beautiful things' she can make.

Basteln may be incorporated into the Beschäftigungen, but can also be an unplanned activity of its own, it stands inbetween the more formalized learning and 'free play'. Free play is an integrated contrast to the Beschäftigungen and the prescribed parts of basteln. It is the room made for play which the children organize themselves. Its goal is thought of as aiding the development of the imagination. In the daily round of things it can be regarded as occasions when the children decide for themselves what they want to do. Play in the Puppenecke or Bauecke is of this kind, as are the short periods of play outside in the kindergarten yard. This play is thought to be necessary to balance the more demanding learning situations. But this relationship between the ideas about 'free' and prescribed activities is problematical. The valuation of learning and order is high and imaginative work may easily be felt to be messy and aimless. 
Heike is checking some of the children's folders, putting in drawings. There is one picture which does not have a name on it and she asks whose it is, but no one recognizes it and Heike says that she cannot see who has made it, which seems to disturb her a little, since pictures are understood as expressions of the person who has made it, and as teacher she expects to know all the children. What teachers and parents look for in a drawing is ability, that is, if the child is 'good' at drawing or painting or not; if it uses 'correct' colors; if it represents things 'as they really are'. What is looked for are signs of technical accomplishment in accordance with certain notions about age differences and developmental stages, and about talent, which in other contexts may be termed intelligence.

Frau Meier, especially, has pronounced ideas about the use of colors and forms. It is assumed that a child should draw and color a picture in a certain way when it has reached one or the other age. Looking at Hilda's drawing of a cat, she found that Hilda, who is four, draws like a four-year old should - a head with eyes, nose and mouth and with legs attached to it, that is, no body. She likes her picture, it is good. If a child uses very much black and yellow in its pictures, she becomes wary, since these colors are negatively charged. There is perhaps something wrong with the child, it is not developing as it should. She will then keep an eye on the child, try to get it to see through brighter, more harmonious colors when drawing or painting, more in line with 'how the world looks'.

The children are often praised for their drawings, simultaneously encouraged, or more emphatically told, to fill out the picture - you can do some more, can't you? a tree, perhaps; why not a sun? You need some more blue here for the sky, don't you?' The teachers point to how things look in 'reality', they admonish the child to make something which is recognizable, something which accords with how things really are. 'How things really are' also implies that they are 'nice', so the child should make a picture which is real and nice. Their notions about development mean that children perceive reality in accordance with their developmental stage, that is, it is assumed that a small child does not see what the adult sees. For example, a small child will draw a bus making it look like a carton because that is how it sees it. Later on, when it is older, the wheels will be added because then it sees them, too. 'A child only draws what it sees', according to Heike, which makes the child into a realist, but on a lower level, so to speak, than the adult. 
This correlation between perception of the 'outer' world and its recreation through a particular medium, in this case drawing, makes it possible for adults, educators and parents, to judge any individual child's achievement on the basis of their own view of what is real or not. It is the adult who appears as the best judge of reality.

Phantasie, fantasy or imagination, or creativeness, is admired and is thought necessary to encourage in the child. But notions of creativity are ambiguous. Teachers and parents will once in a while express disappointment or annoyance when the children's drawings look too much alike or when they seem to want to copy in particular the teacher's example, as if they do not use their own imagination. They are caught between the striving for predictable order, the schön saubere Arbeit ('the nice clean work'), and the perhaps unruly process of imaginative work. The final result of 'creativity' may be admired, but the route there is unpredictable, uncertain, as is also its outcome. This ambiguity is suggestive of the relation thought to be found between order and independence, and freedom. Without Ordnung freedom does not seem possible for Lindeners. ${ }^{4}$

Why should creativity be admired at all? As Heike and I are talking about the children's drawings of Easter eggs which are hanging on the wall, she says that she finds it difficult to say very much about them. They were supposed to draw a colorful Easter egg aus freier Phantasie ('from free imagination'). 'They all have about the same idea about how such an egg should look, they've all seen them at home', so Heike means that they look pretty much alike, some better, some worse. For her the main point is to decide which are good drawings, which are bad. Those who have hardly made any patterns, or very unelaborated ones, or not completed the form of the egg, letting the colors fade into an elusive emptiness at the bottom, these children have just been lazy or unconcentrated. Pictures are not usually talked about as symbolizing anything, they are seen as signs of development and talent, sometimes also of the good or bad character of the child. When a child is three and a half it should be able to draw patterns, for example on an Easter egg, Heike thinks, 'it's just that they don't have the patience to finish it'. Which they eventually must learn to have.

The children are given certain drawing tasks, with instructions as to what they should be like. In addition they are usually allowed to make two 'free' pictures a day, that is, draw what they please. Often they will prefer to use the various templates, rather than drawing on their own. Perhaps 
part of the enjoyment of using the templates is that the results are predictable and 'real'. There is nothing to add, nothing to criticize, nothing to defend. For the girls, at least, there is the additional pleasure of being able to do something as nice and pretty as die Heike can. They come a bit closer to her, in achievement and also emotionally.

\section{Putting things in order: aufräumen}

When Kindergarten is over for the day, Heike gathers the children in her group for prayers and asks them first of all who has been good at aufräumen ('tidying or cleaning up') today. The children start telling her loudly and excitedly all they have done - keeping the Bauecke in order, putting away crayons, paper, clothes, and so on. 'Heike, Heike! I did it, I did it! But Rainer didn't do anything, and neither did Sabine!' And so it goes on for a while, the children telling, bragging, tell-taling. Heike praises, laughs, and reprimands. Those she decides are the really good ones are given a piece of candy each. Usually, she will have seen for herself that they have been helpful and orderly.

During the whole day in kindergarten the children are, with short intervals, told to tidy up, aufräumen. Everything must be put in its right place as soon as it is no longer being used or the game is over. 'Who has been playing in the Bauecke or in the Puppenecke?' Aufräumen! Komm, auf!' The teacher is heard calling this many times during the day. It is very important that the same child who has used a particular material be the one who also puts it back. Some children are known to try to dodge from tidying up, but are usually caught either by the teacher or by some child who 'tells'. The teachers consider it particularly important that these children do their share of the work, so as to learn that it is of no avail to try to shirk from it. If they are slow, even to the point of missing a new activity, they are not to be helped, they must learn to manage by themselves.

Aufräumen has an essentialistic quality to it. This made itself felt when Heike told Frau Meier and Hildegaard in an evening conversation about having made an aufräumen-sequence into a game. She had told the children to pretend that they were dogs looking for bones, in this way getting them to quickly and efficiently find everything not in its place and restore it, pick up bits of paper on the floor, and so on. There was a roar of barking dogs, the children running around on all fours, having great fun 
in tidying up, which they also did quite quickly - although a few of the boys did not want to stop being dogs. But Frau Meier was not very amused. She does not approve of such methods, she says. Heike looks somewhat annoyed and embarrassed, but she does not defend her actions. Frau Meier considers that one can praise the children when they have tidied up well, certainly. One can even give them some sweets, but making a game of it all is to deny the seriousness of the matter, that is, that children must learn to realize why one must tidy up, that certain things must be done, and it is not for fun.

Almost an hour before leaving kindergarten the final aufräumen is announced. When Hildegaard is alone she has certain problems in getting all the children to participate. Her mild voice and careful manner do not seem to help her, but the giving of sweets to those who have done well may do so in view of the next time. Several of the children try to get candy without having deserved it, but here Hildegaard does not give in, there is no way of getting her to give candy to those who should not have any. Hildegaard is not good at forcing but she can withhold, which is another aspect, and a not unimportant one, of being an authority.

Aufräumen seems in itself trivial enough - putting things back where they belong, picking up trash from the floor, wiping the table, etc. - but its 'meaning', its place in the whole complex set of meanings having to do with life in kindergarten, the life of children, is after all not so trivial, but neither so very obvious. It may be practical to put things back in their places, but what constitutes 'their places' is part of the matter. This is seldom motivated, as if things (must) have a preordained place, a place almost not decided on by man himself but by the nature of 'things'. Through classifying and trying to make the lived world known, people will always be achieving some kind of order, but it is a different matter when order in itself is part of an ontological preoccupation, as if order were the route to a totality, a higher unity. It is in relation to this encompassing Ordnung that I think the 'necessity' of aufräumen must be understood. It seems analytically meaningful to look at it as connected with the values and conditions of hierarchy and ideas about dirt, that is, the well-known postulate of dirt being 'matter out of place' (Douglas 1966), and so potentially dangerous (I made a similar note above, chapter 3 , in relation to the show of dependence in small children). The more hierarchical, and so bounded, the parts of society, the less its ideological toleration of the transgression 
of boundaries, of dirt and impurity, and the more its preoccupation with purity - order, cleanliness.

The kindergarten in Städten, a town near Linden, which does at first sight seem to contradict this ideological preoccupation with order and cleanliness, and even obedience, is termed by the teachers in Linden and Altheim as 'anti-authoritarian', that is, as completely disorderly. This is hotly rejected by the teachers of Städten, who maintain that they rather hold to a higher sense of order, through which both the unity of the group and individual creativeness can be developed.

The kindergarten in Städten is a non-confessional, municipally financed kindergarten. The gossip that it is an anti-authoritarian kindergarten is countered indignantly by the head teacher who says that it is 'thoroughly pedagogical'. All situations are seen as moments of learning and so the day runs on as 'a whole'. There is no interruption of activities by organizing Beschäftigungen or making a particular distinction between such activities and 'free play', neither are children interrupted for aufräumen. Instead, things are put back in their places all along, order is not announced (making it into a special activity) but is seen to be embedded in the totality of the activities, which in turn are part of a continuous learning process. In this way everything has a motivated goal. An essential part of this process is that the children should really become familiar, intimate, with all kinds of different materials, such as different colors, forms, textures, sizes.

Each little space and corner, each table is meant to have a special purpose - a place for building blocks, a place for doll-play, a place to read, and so on - not a very different categorization from that in Linden, but felt by the staff to differ greatly since the 'ordinary' kindergrten, like the one in Linden, does not have a pedagogical ambition such as theirs. They are felt to leave more to the course of circumstance and unreflected notions of order, and the children do not 'develop' as well as the children in Städten.

Control is not practiced in quite the same way as in Linden. Punishments and rewards are not as distinct from each other and not as strict or obvious as in Linden. The endeavor is to create an image of an 'encompassing whole' based on the individual, differentiated through its freedom to create and itself encompass a total order, a unity.

The kindergarten teachers in Städten and Linden/Altheim feel that they differ very much from each other. There is a marked antagonism 
between them and only superficial contact. Daily routines are to some extent different, there are differences as to how the pedagogical ideology is proclaimed, but basically these are variations on the same theme of Ordnung and lernen, individual and collective. In the Linden kindergarten aufräumen becomes an important and routinized means of attaining and maintaining the ordered person in a bounded and controlled group, whereas the Städten kindergarten is more ambitiously striving to establish an unbounded link between person and the whole, not using this activity or any other as markers, unity is simultaneity. Aufräumen as such is not disdained, only the way it is used, along with other activities. It is felt that the day is fragmented, disintegrating the whole and erecting too strict boundaries between activities. This is thought to hamper the freedom of the individual by not making Ordnung stand out in its completeness.

\section{The performance of praise and punishment}

It is early afternoon on December 6th, Nikolaus Day. ${ }^{5}$ In the central hall in the kindergarten all the children are gathered and sit on low benches. They wait for Nikolaus to come. When the children are seated, Hildegaard reads from a book about Nikolaus, where he comes from, his good deeds. Nikolaus may instead do this himself, or even stage a minor hearing among the children to see if they know who Nikolaus is. The children sing a few songs they have spent many hours rehearsing the weeks before. When all is still again Nikolaus appears at the main door in his imposing bishop's costume - golden headdress, mantel, and golden staff (the mantel is a loan from the Herr Pfarrer).

Nikolaus is associated with a sack of gifts, which his traditional lackey Ruprecht sometimes carries. This sack is also transformed into a threatening means of punishment, for which a rod instead can serve. Often Nikolaus comes without Ruprecht and himself has a sack or a rod. As it was in kindergarten, the sack and rod were not conspicuous or even noticeable from the beginning, although the children are well aware of their existence.

Wir grüssen den lieben guten Nikolaus! ('We greet the dear and beloved Nikolaus!'), the children call out in greeting at a sign from the teachers. Standing in front of the children he looks at them a moment (and some of the children take note among each other that it is the kindly old 
verger, Herr Grün, who is Nikolaus this year). He opens the large, goldcovered book, which the teachers have made, and recites in the monotone drone of high German about his long and strenuous journey to come visit them, thereafter saying that he wants all children to be good and wellbehaved.

When this introductory part is over he calls forth small groups of the children, by name, according to a list the teachers have prepared for him. The children, divided into small groups of 4-6, are either to sing a song for him or recite a poem in unison. Some play the flute, others perform a ring game. Frau Meier, Heike and Hildegaard sit to the side of the group and keep prompting the performers. Nikolaus, in turn, tells them to sing louder or better, others he praises for doing well. He says to them, looking down in his book from time to time, that they must all aufpassen ('be attentive'), be well-behaved and do their tasks right. He mentions by name those he 'knows' do not usually sing along with the group, those who are inattentive, those who are lazy and do not help aufräumen. The teachers assist Nikolaus by calling out details about this or that particular child, his or her failings in the group.

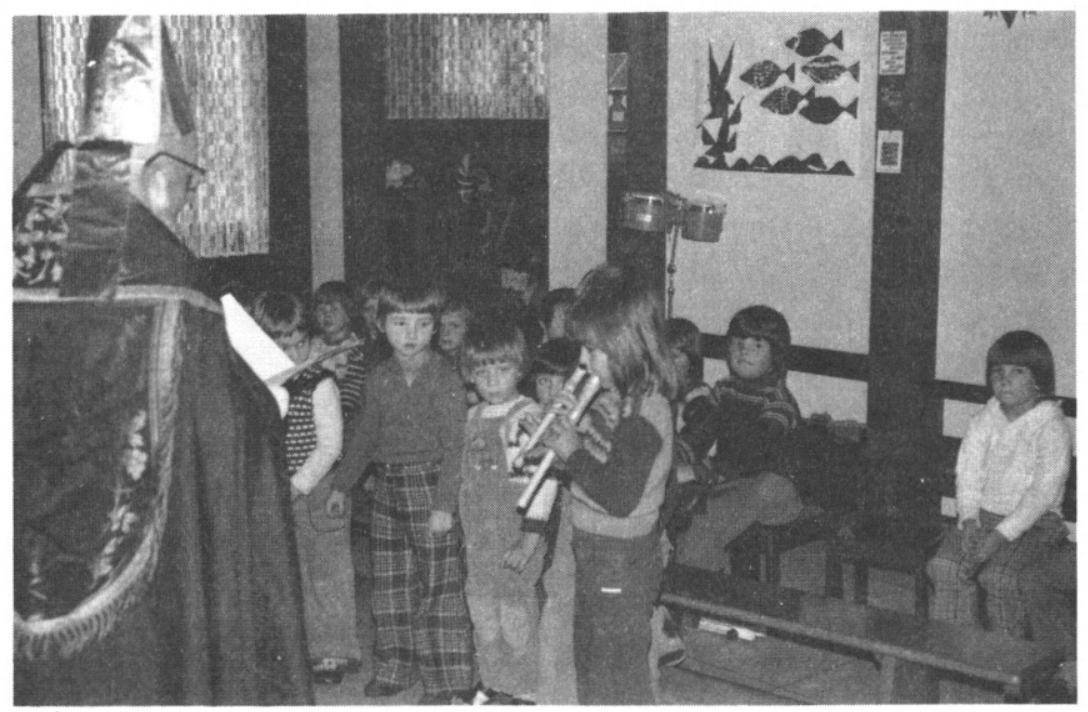

A group of kindergarten children perform for Nikolaus. 
The children of each little group stand before him listening, at times with some uneasy movements. The others sit and watch. In one group, for example, Hannah is praised for being a good child because now she has learnt to put on her coat and shoes by herself, whereas Marina still cannot manage this. One child is reprimanded for being too curious, Beate for tattling; a few boys for playing too wildly inside. One little girl is too domineering; one boy always tries to stop other children from playing in the Bauecke or Puppenecke. And Tina is too protective of her younger cousin Edit. Sandra and Walter are often bad-tempered. Two boys are far too slow in putting their shoes and jackets on. That is not nice at all, Nikolaus tells them intermittently, declaring das will ich nicht mehr hören! ('I do not want to hear of such things again!'). Finally, it is time for the careless children to get their due share of reprimands. Six are asked to come forward and get their scissors back which they all have mislaid several times and which the teacher has taken care of until now. They shuffle about, take their scissors a bit shame-facedly and go back to their seats.

When all the groups are seated again, Nikolaus turns and gets his rod and Frau Meier tells him that there is a boy in her group who always scratches and bites the other children, 'so now Georg can have a taste of the rod', and Nikolaus goes up to him and rubs his cheek carefully with it. Georg sits very still and the other children peek at him, no one says anything. Frau Meier, perhaps not finding this Nikolaus emphatic enough, tells Georg, 'there you see how it goes, now you can see what it is like!' and she looks at him quite disapprovingly. Hildegaard calls out cheerfully that she also has some naughty ones in her group. 'Here they are all three of them - Thomas, Peter and Herbert!' and they also receive 'a taste of the rod'. Nikolaus lets all of the children touch the rod with their fingers as he slowly goes by them row after row,and they nudge each other or giggle shyly. Some of them are eager, others hesitate, but they all reach out to touch it.

On other occasions a sack is used instead of the rod and the teacher may ask if there is any böses Kind (bad child), that Nikolaus should take with him in the sack. Usually there is at least one child who qualifies. The year before, Frau Meier called out that she thought Uwe was bad enough to be thrown into the sack - 'he frightened Martin who is much younger than he is, that he would be thrown into the sack. That's why he's crying the whole time today. Well, then Uwe can try it instead and so learn not 
to frighten others!' At this Uwe burst out crying, denying that he had said such a thing to Martin - 'it wasn't me!'. 'Oh, so it wasn't you; well, in that case ...' and the teachers laughed and Nikolaus was on his way without Uwe in the sack.

When this part is at an end the teachers help Nikolaus distribute small gifts to the children - an orange, a miniature jigsaw puzzle, crayons, a small yellow top. Then Nikolaus must be on his way. He thanks them for their songs and performances, he has enjoyed himself. They all call good-bye and then go to their respective rooms to have cookies and soda, which are instead of the sweets they usually receive.

Nikolausfeier, the Nikolaus celebration, can be staged in varying settings and used for somewhat different purposes, depending on who arranges the ceremony. ${ }^{6}$ In the homes, small children will find little red plastic boots filled with sweets, cookies, and fruit standing outside their front door or perhaps by the fire-place. In some families a parent or a close relative will dress in a Nikolaus costume and come with a sack of sweets and gifts. This coming with a sack and with sweets or gifts plays on the well-known theme of praise or rewards and punishment. Nikolaus is a more prominent figure in kindergarten and in associations with many children as members, associations which have an educative goal in relation to children, such as the Musikverein ('music association').

The central features of the celebration are the giving of sweets and the threat of destruction, symbolized by the sack mainly, but even the rod. This is more or less emphasized and elaborated on, depending on the context and the audience. In the Musikverein things are a little different from kindergarten.

On a Saturday evening in the Wirtschaft, the association has rented the large back room for the evening and it is full of people, families celebrating Nikolaus Day. The children of the orchestra are standing behind Herr Dahmer, the president of the association and the band leader. They are dressed in the association's blue and white uniform and play their brassband music. They are grouped age-wise, ranging from the ages of eight or nine to sixteen, seventeen, and the three age-groups play alternately American Christmas carols, polkas, marches, waltzes. Highly appreciated by the audience.

After this, and a fairly formal welcome speech from Herr Dahmer, 
it is time for Nikolaus to make his entry. The baker's brother-in-law makes a tall and handsome Nikolaus. His costume is rich but he does not wear the beard. Holding the large golden covered book, he reads the arranged epistle with a sonorous voice, praising the Musikverein and Herr Dahmer for his great capacity to teach the children music and in keeping music in Linden alive and thriving.

Each small and big musician is then called upon, 2-3 at a time, some one by one, to come forward and hear Nikolaus speak. He has heard about their faults and misbehavior he tells them, and they are duly reprimanded for being lazy, for not practicing enough at home, for talking and disturbing during rehearsals, for not coming in time. All this is said with gusto and people laugh. Some applause is heard as the children return to their seats after having received a paper bag full of sweets and cookies. The older children receive most of the praise, whereas the smaller ones are more reprimanded.

With an audience of adults it is necessary that Nikolaus is eloquent and witzig ('joking', funny). Through a stern, ironical, and teasing style he is entertaining, while divulging the weaknesses and faults of others, the children and thereby the parents. The children take it, though sometimes they appear embarrassed or confused. And one can see parents in the audience who lose their smiles as they are mentioned indirectly through the misbehavior of their children, others joke with each other about their feeling of being uncomfortable.

The children are here publicly confronted with ironic teasing and joking, which is part of the discourse adults have with their children. In this context the rod or sack is not used, since the teasing and joking can elegantly replace them. With an adult audience and children who are not so young, a good verbal performance is as efficient as a sack or a rod.

The teachers stress the enjoyable aspects of Nikolaus, as the parents do, it is a treat for the children, 'the children want it', but they will also point to the necessary achievements of the children, how good it is that they learn to perform, and not least, learn that one must take responsibility for one's (mis)behavior. As Nikolaus is celebrated in kindergarten it stands out as the first public event in which the small child is presented with the precariousness of its own individuality and the limits of its parents' authority. ${ }^{7}$ Dressed as a mighty bishop and encompassing that intriguing Christian combination of great benevolence and righteous anger, 
Nikolaus comes to embody the church which may also be an embodiment of the totality of the good society, the good state. In the claim that he is an historical figure lies part of the legitimate claim to his authority. History implies that which is 'real', which makes belief in him more compelling. Assuming that something can be historically established implies that it is raised above the level of mere make-believe or 'superstition'.

The more frightening aspects of Nikolaus are deplored by many parents, although they will laugh at memories of frights. The moralizing or vengeful aspect of a Nikolaus celebration is seldom completely dropped, although this is a more prominent feature when Nikolaus is celebrated in a public situation. ${ }^{8}$ The sack is really more a thing of the past, the Hirsch's say. Frau Hirsch remembers a humorous outcome of the usage of the sack. It was a relative of hers. When he was a school boy an uncle of his was Nikolaus and gave him a beating and put him in the sack. The boy was very impolite and naughty, she tells me. But he had taken it standing and when he came back in he had exclaimed 'that was just like Uncle Heinz!', although he had not known that it really was this uncle (so the story goes). This gives them all a good laugh. It is the kind of underlying stoical attitude of 'take what's coming' which is much appreciated, and the story appeals to just that. The culprit gets what's coming to him, but he had fun (being mean, disorderly) while it lasted. This is appreciated and laughed at just like one appreciates and laughs at Max und Moritz.

The suspense of the Nikolaus celebration lies in the re-enactment of the tension between punishment and gifts (good things to eat), and I would think that it is this suspense which contributes to making the Nikolaus celebration seem both meaningful and enjoyable to adults. To them it is a distanced re-enactment of similar childhood experiences. Perhaps as Lewis sees it, "Ritual is not done solely to be interpreted: it is also done to resolve, alter or demonstrate a situation" (1980:35). ${ }^{9}$ As for the children, I would imagine that a sense of confusion is instilled in them. They are not as able as adults to discriminate between what is meant literally and what is metaphoric. They have not reached the point where they can with a sense of assurance laugh at it all. For them Nikolaus can be a true threat of destruction.

With respect to the problematics of punishments and praise, the children are not just passive recipients, they also interpret them and put them to 
use in their own way, that is, they find their own means of working the system. One such way, as I see it, is the fairly frequent occurence of telltaling and bragging among the children in kindergarten, of which I give some examples in rounding off this chapter.

Beate comes over to Frau Meier and tells her that Sabine is chewing gum. 'Oh, go away and draw a picture or something, Beate!' Frau Meier sighs. And she says to Beate, Bring nicht die andere Kinder an, ich will das nicht. Warum machst du das? (Don't keep telling on the other children, I don't want that. Why do you do it?). She says to me, as Beate moves on, that she is a real tattle-tale.

A while later Frau Meier gets up to take some of the children into the smaller room for Beschäftigung. The others are left to themselves, playing, drawing, walking around. There is a loud crash all of a sudden. Ulrike just pushed Hilda so that she fell over the play coffee-set and one cup is broken. Frau Meier comes back in, having heard the crash. The other children immediately start telling her who did it, Ulli did it! It was Ulli! Everyone playing in the Puppenecke are calmly but sternly told to get out from there. Hilda is crying and Ulrike is saying that she can buy a new cup. Frau Meier then turns to her, shows her the broken cup and says without much show of affect, but signalling a suppressed anger, that it is not possible to buy just one cup, one must buy a whole new set and such sets are very expensive, they cost at least 20DM, 'and I don't have that much money, Ulrike'. The children chime in, calling out to Ulrike, 'there, you see, Ulli, you've ruined a cup!' Ulrike holds up a cold face, she does not let them get at her, but she does not say anything. Frau Meier finds her as schlimm ('bad') as Beate Heinz, if not worse, 'but then, of course, they're cousins'.

The big children are to draw flowers, they are on their own while Frau Meier is busy with another group of children. After a while she comes in and one after another of the children tell her that Walter, who is sitting on a chair in the middle of the room, has made a Flieger ('airplane') of his drawing - Fräulein, Fräulein! guck e'mool, der Walter hat ei' Fliecher gemocht! Fräulein, guck!('teacher, teacher! look, look, Walter has made an airplane!'). Frau Meier sighs, asks Walter why he does a thing like that, that he should know better, that he is spoiling their work. As this is going on Tina comes over to me and complains that Ulrike ripped off her name from her crayon, 'on purpose she did it!' My question as to why she thinks 
Ulrike has done that, if she has talked to her, seemed unsatisfactory to Tina and so she goes over to Frau Meier whom she must feel will understand her better. Frau Meier does go over to Ulrike and asks her why she has done that. Ulrike says nothing. As she is standing there Frau Meier makes a much graver discovery - that Ulrike and Anja have been cheating. They have gotten hold of some small pictures of different flowers and have them to check against so that their own drawings become as correct as possible. 'How could you?! Now the whole task is invalid! Shame on you, Ulrike! You are always doing things like that! Now you stay put right here until you know how to behave!'

Frau Meier does not yell and scream at the children, which perhaps has to do with her personal disposition, but for this analysis the importance of that is that it would be unpedagogical, just a sign of 'old-fashioned authoritarianism'. In this way kindergarten teachers may differ from parents, who are more likely to yell at their children when angry, slap them perhaps. But the restrained anger is more of the modern pedagogical way of handling misdemeanors, talking calmy, explaining, punishing in accordance with the offence as it may, in different situations be interpreted. This is deemed more correct and even admirable than a show of 'blind anger'. Frau Meier's actions are thought to make the children understand why they are punished or reprimanded.

When Beate has difficulty making a paper flower and is nervously trying to understand how it is to be done, asking Frau Meier again and again, some of the other children begin to brag, contrasting themselves to Beate, wanting Frau Meier to praise them as she is reprimanding her for not listening, not being attentive - that is, not being capable. A situation like this is fairly common. When a child is being reprimanded, especially sternly, somewhat humiliatingly, some of the other children will often start telling the teacher of their own good accomplishments, or perhaps add to the 'story' of the child being in negative focus.

The teacher moralizes and punishes and praises, and the children work on this model. They have a situation to cope with which recurs, not identically, of course, but recognizably in terms of the model for praise and punishment within a moral frame. These seemingly simple situations stir up different feelings in the children, I would assume - of fear, anger, revenge, rivalry. The teacher need not do or say very much for the children to start reassuring themselves of her good-will towards themselves, and 
they will appeal to her through her own means - by trying to master the idiom of praise (bragging) and punishment (tattling). There are other situations, not connected with a direct conflict betwen the teacher and a child, when a child starts bossing another child, telling it to aufräumen, and so playing the part of the powerful adult.

The children hardly ever attack each other for tattling, which is part of that which I have briefly mentioned above - tattling is mainly part of a cultural discourse with the adult, the teacher - or in other cases, the parent. Only indirectly does it refer to the child who is the target. And it seems as if the children are not bothered enough by this to start fighting or stop playing with each other. I think that the annoyance which Frau Meier and Heike (as also parents when children come home and tell on someone) express at times when the children come and tell on each other is that these children are driving 'the system' a bit too far, they are 'dragging in debris' formed by this very ideological system of order and obedience. They are revealing its weaknesses, its defects, for the norms are not such that they say to tattle, brag, but rather to be well-behaved, orderly, helpful, obedient and polite.

Hildegaard is sitting with the children in a circle with their little chairs. Frau Meier is in the other room. They are going to sing a song while waiting for Frau Meier, but they are all very noisy and will not sit still. Hildegaard with her soft voice tries to quiet them down, 'now you are to keep quiet until Frau Meier comes, we'll all sing a song, together!' No, read a poem instead! shouts Ulrike. No, not that poem! shouts another. Hildegaard cannot manage to get them to cooperate - or obey. Ulrike is domineering, starts singing loudly and off key, and the others start singing along with her, loudly and incoherently. For some reason, Ulrike rushes up and hits or pushes Anja, then sits down again, puts her hand over Walter's mouth to stop him from singing. Hildegaard is helpless.

Then Frau Meier comes in, quite moody, and tells them all how very disappointed and annoyed she is at their bad behavior. The children immediately simmer down and after a short while Anja suddenly starts complaining to Frau Meier about Ulrike who had hit her. Frau Meier does not answer, she does not attempt to do anything about it. She just looks very stern and has them sing some of the songs as they should be sung. Anja and Walter, who are trying to get her attention to tell her what has been going on, are completely ignored by her, as if they were not there. 
With fairly small means, but with a long history, order is restored and as soon as full control sets in the door opens wider for tattling. And the teacher sighs, again, unable to understand the workings of the system she is also forming.

Kindergarten appears in many ways as a bounded ideological and behavioral system where the main actors, teachers and children, are made aware of the precariousness of 'being in a group'. The aim of kindergarten is to place the child in the wider social world, the world which is deemed to be beyond the competence of the family. Through sets of prescribed activities the child is to realize its individuality and understand its limits and the necessity of subordinating to a group. This has been part of the educational endeavor, although differently formulated, since Fröbel's days. It has to do with the seemingly unsolvable problematics of reconciling notions of individual freedom with the maintenance of a superordinate whole. Such a project demands its means and creates its obstacles and these are recurring themes which reappear in the different educational contexts, the school not least. 


\section{5}

\section{Coping with pedagogics: the early school years}

Da hast du recht! ('There you're right!'), says Herr Mann to his teacher colleague Frau Rasch as they, together with two more teachers, stand at their usual place near the main entrance of the Steingrund elementary school watching the children at recess. He is not upset like Frau Rasch but thinks she is making an important point as she complains that today's children know no boundaries: 'At home they do whatever they please, no one stops them! And nowadays the teachers aren't allowed to do anything either, just use words, words, words'.

It is the morning's first recess, twenty minutes, enough time to eat a sandwich brought from home or, much more tempting, buy one or two large buns from the 'baker's wife' who comes from Linden every morning with their van loaded with Brötchen und Weck ('small bread rolls and sweet buns') which she sells. The children rush to buy from Frau Wald, but the teachers usually see to it that they have first choice, after which they retreat to their small 'platform', eat their buns while commenting on their quality.

The paved school yard is filled by some 150 second through fifth graders, many of whom are bussed daily from nearby Linden. Most of the girls skip, some of the boys keep pestering them, others play tag. The noise will at times become almost deafening, with shrieks and laughter, not seldom there may be quite hard fighting between some of the boys. The teachers seem undisturbed and it is only rarely that they will intervene in 
anything the children are doing. The children are on their own, let loose. Their boisterousness and loud play is a sign of the energy which adults assume that children need to let out. Situations like this, on the 'outskirts' of organized events, can have their own wild structure. It is only demanded that the children learn to differentiate situations correctly, that they can oscillate between the ordered and the wild. In this way, even in class children may at certain times be much louder and livlier than one would expect without the teachers seeming to be especially disturbed.

Ordnung is necessary, as we have seen, and the school plays a crucial role in the creation and maintenance of order, the formation of ordered, independent persons in an ordered society of good equals. This task of the school is performed through teaching and demands set on learning, but the content of this learning and the means by which the goals can be achieved have been a controversial issue in Germany recent decades.

The debate became particularly fierce during the 70 s as a result of the intensification of the political conflicts which developed in the late $60 \mathrm{~s}$, something West Germany shared, to some extent, with the rest of Western Europe. The whole of West German society and state legislation seemed to come into question and this was epitomized very much within the realm of education, that is, Erziehung, including school as well as child upbringing in general.

The school system has expanded since the mid-60s and changes have been made to enhance a more 'democratic and egalitarian' opportunity structure. The late $60 \mathrm{~s}$ and early $70 \mathrm{~s}$ was aperiod of intensified reform (cf. Baumert et al. 1984). ${ }^{1}$ Among critics, the German school system has been seen as catering to the different occupational and prestigious levels in German society, almost from the beginning dividing the children into more or less closed 'strata'. Terms such as Bildungsnotstand ('learning-disaster'), Chancengleichheit ('equal opportunity'), Demokratie lernen ('learning democracy') became central in the discussions referring to the deficiencies of the school system. In the 70s, more socially relevant education was sought after, and educators and politicians spoke of the necessity that pupils learn to become responsible citizens and cooperative creators of unser freiheitlichdemokratische Ordnung ('our free and democratic order'). They should be critical, emancipated, and be able to deal with conflicts. The pupil was to be the central focus and not the material to be learnt (cf. Dohnanyi 1971).

As it seems, from whichever angle critique has been voiced, ideas 
about learning usually combine responsibility towards the state with a concern for democracy and freedom. This may not be specific for Germany, but then again in Germany the concern for democracy and freedom is related in an ambiguous way to notions of order and loyalty towards the state. Subordination and individual freedom are problematically linked, historically, and I think also in contemporary Germany as I understand it partly, but primarily, through the workings of Linden.

Already at the time of my fieldwork some commentators feared that the ambitious goals of reformers were being lost in the everyday realities of school life. That is possible, but I will not attempt to make any kind of evaluation; instead it is my aim to give an ethnographically informed account of the ongoing discourse about school among teachers and parents in the Linden area, pinpointing some of its recurring notions and themes and their ideological and perhaps one could say, ontological, foundations, which bind Lindeners together. What is to be learnt? Why do some learn where others fail - and who is to blame for the shortcomings? ${ }^{2}$

'The children just never learn to take responsibility! They don't learn that in a society one must give, not just take,' Frau Rasch concludes as the bell rings and the children rush and shove to line up class-wise. Herr Mann nods, da hast du recht.

\section{First grade, first day}

School starts in the middle of September when it is still warm and summerlike. The very first day of first grade nicely dressed mothers take their nicely dressed children by the hand and go up to the school. The school building is the pride of Linden. Built in the late 60s, it is felt to be modern, with light and spacious classrooms, wide staircases, and, for its fairly small size, quite imposing corridors. It has replaced the old and crammed school house which lay close to the church in the middle of the village. Now it lies on the hill top overlooking it, surrounded by the newly built houses and close to the even newer kindergarten.

Frau Heim, the first grade teacher, stands up front by her desk and the blackboard, behind her a dark and penetrating crucifix. The children are seated and their mothers, of whom so many have themselves been Frau Heim's first grade pupils, stand at the back of the room.

On the desks before them the children have each an enormous paper 
cone filled to the brim with sweets, mainly, also fruit, perhaps a pencil and crayons. It is the obligatory Schultüte ('school cone or bag'), which every German first grader receives from its parents on their first school day. 'That's the way it's always been', people say and show me pictures of themselves as children holding the grand cone. Perhaps it is a way of easing the step into the demanding world of lernen, one mother suggested, shrugging her shoulders and laughing. As has been mentioned already, sweets are a kind of materialization of this cultural theme of praise and punishment and discipline. They occur almost noncommittally in everyday situations and they are focused in certain ritualized situations, made into a form of offering to the child, if you will.

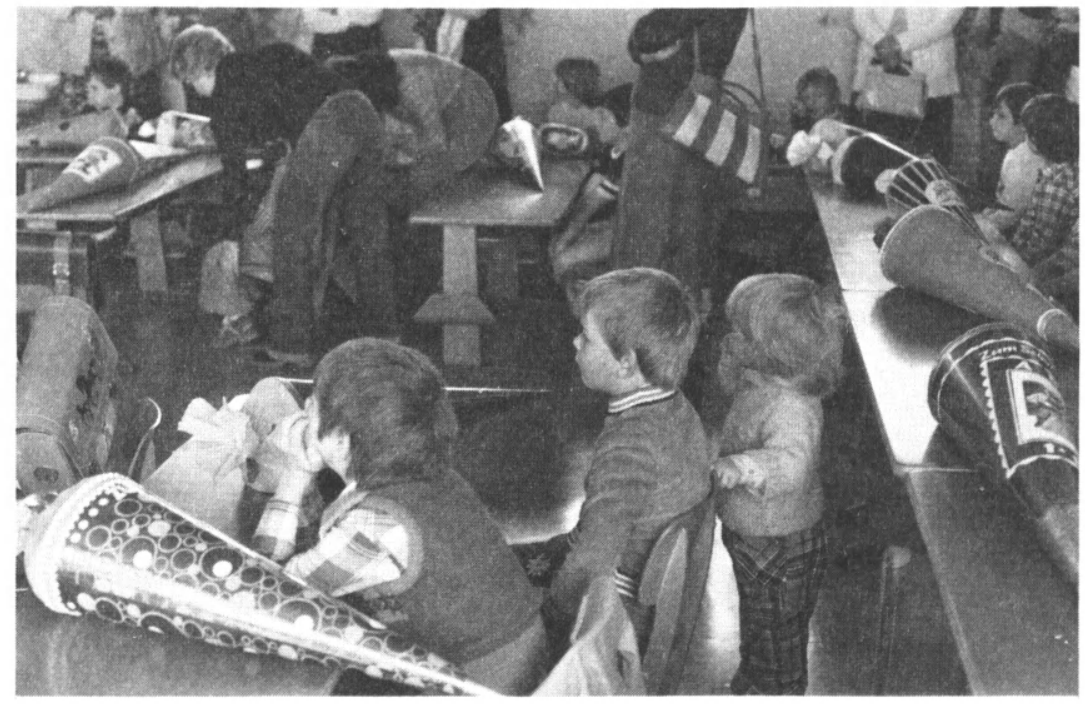

A Schultüte is given each school beginner.

Everyone is still and quiet as Frau Heim talks. She has welcomed them all and has handed out some written information about material the children will be needing - pencils, scissors, notebooks. The school does not provide this for the children. She gives the dates of the holidays during the year and tells them that the children will soon receive bright yellow scarves, for the girls, and caps, for the boys, which they are to wear on their way to and from school, so that they will be easily observable in 
traffic, 'children of this age are usually lost in thought and do not notice what is going on in the streets'. The children seemed to think the color was too bright, at least they were not seen wearing the scarves and caps for long.

There followed some admonishments, which Frau Lender with her third child now starting school had already recited to me as we left in the morning - the children should definitely go to bed early, seven o'clock is quite late enough. School is strenuous, the expectations on the children are higher than in kindergarten and their ability to concentrate is very much diminished if they spend long evenings watching television. They should also eat a good and nourishing breakfast in peace and quiet. A child who has not eaten properly cannot learn, this she knows from many children'. The mothers are made to feel that if they follow all of her instructions their children will learn accordingly - reading, writing, arithmetic. By Christmas they will all be able to read, she assures them, but, of course, some better than others.

A central feature indeed in all German school education is homework. School days are comparatively short, ending at noon or one o'clock, which means that several hours should be spent at home doing homework. For these young children demands are not so hard, though. Frau Heim wishes to speak to the mothers about homework. The children must be able to sit and do their work undisturbed by noise and other activities, and they should be encouraged to work independently. Parents should not try to teach their children more than what the teacher does, trying to get ahead. Parents and teachers teach differently and so the child would only become confused, whom should it follow? the child will ask itself and presumably not find an answer. 'The important thing is that children are praised. School work is difficult and they need praise. They will not work better if they are scolded or slapped, it will only make them nervous'. And she exemplifies how one can praise the child - 'this is fine, well-done, tomorrow maybe you can do it even better'. The idea seems to be that expectations on a child should not slacken, parents must keep pulling and pulling to get the child-plant straight, otherwise it will grow crookedly. Although a garden analogy is not explicitly referred to here, it nevertheless links well with the notions mentioned earlier in chapter 1 about child upbringing as a kind of garden work, the child represented by the growing plant. 
All is quiet in the classroom, no one has any questions when she turns to the parents and asks if they have. She continues. Sometimes it happens that she has children in the class who are afraid in school, as soon as she comes near them then 'schlupf! they slip under their desk as if wanting to hide', and this without anything having happened. Now, this 'irrational behavior' she explains by referring to a tendency among parents to threaten the child with school, saying, for example, 'you'd better watch out or else you just wait and see in school what will happen...!' This is not at all a good thing to do, frightening a child like that, they will not have the right attitude towards school. Of course, she says, she will at times scold the children when they are too loud and disorderly, she may even become a bit loud herself, she laughs, 'that's just my nature, I can't help it'. But she does not hit the children, she assures them.

There is one last point Frau Heim wishes to mention before the mothers leave. She wonders if there is any child in the class who suffers from Blasenschwäche ('weakness of the bladder functions'). No answer, no one moves. She stresses the importance of her being informed about this, and this also includes 'intestinal disorders', that is, children who often have diarrhea. Lessons are one and a half hours long, and a normal, healthy child should be able to last through without having to go to the toilet. She cannot let others than those children with such problems go to the toilet during lessons because as soon as one starts off then all of them end up standing in line to go. At this last somewhat sarcastic observation of child behavior, the mothers smile knowingly and are relieved of the burden of having to declare themselves normal or not.

It is time for the mothers to leave, the children stay on alone with Frau Heim for a little while. The mothers say good-bye, stroke their child on the cheek, give a light kiss, straighten a shirt, the hair, and remind to be well-behaved. One mother does not receive any response from her son, he does not seem to notice her, so she finally shouts good-bye - oh, he gets on my nerves! she exclaims as she leaves in exasperation.

This initiation into school life and the status of Schüler ('pupil'), is given its final seal in church the following morning. The church is filled with school children sitting up front along with the teacher and some of the mothers. A bit farther back sit the older, darkly dressed women, the few who still go to Mass every day. 
After prayers and psalms - a few of the older school children read from the Gospel and say prayers (intercessions) - the Pfarrer has a few words to say to the children. He steps down from the altar ring, moving closer to the congregation where a table has been placed for the occasion. On the table lies a Schultüte. With this school symbol as a point of departure he speaks to them of the importance of maintaining 'moral values'.

First he takes an apple out of the Schultüte, holds it up for the children to see. Die Schule ist wie ein Apfel ('the school is like an apple'), he says, 'and like this apple, whole and perfect as it is, should the school and the school year be. There are no worms in this apple, it is not decaying. So I say to you children, go to school and do your duty!' Thereafter, he takes out a school schedule and a football. 'Much time and strain is needed to achieve in school, the school requires hard work and your contributions. But there should also be room for other things - sports and music, and the church!'

He holds up a drawing of a teacher helping some pupils. 'It is important that the relationship between teacher and pupil is good, that the pupil obeys the teacher'. Finally, he takes out a string of beads. 'This string of beads I can tear apart with force and then all the beads will fall to the floor and be scattered in all directions. But as long as it remains whole then each bead is held close to the one next to it and together they form a whole. That is how you should keep together in the class, be a Gemeinschaft within which everyone helps and supports one another! Such is also the goal of the faithfully Christian pupil!'

That the church is involved in sealing the school start ceremony has been a recurring event, but the Pfarrer, who was intent on setting his own mark on Linden activities, created this ritual performance more or less on his own. The geniality lay in its simplicity and directness through using the Schultüte, this loaded and liked symbol, but transforming it by giving it a different content. Instead of sweets and associations of home, it was filled with messages of a moral order. He made the children curious as to what would come next out of the bag, not just relying on words but on materializations of words, materializations which lead away from home into a higher unity, the person is lead out into the world. It is a kind of 'moral building', as it were a paraphrase of 'nation-building', appealing to that which is beyond the individual, ideals which can only be attained through merging into a unity, a unity sanctioned by church and state. 
Before turning to the story of these 'beads', to use Pfarrer Kreis's analogy, I shall give a very brief presentation of the German school system in general.

\section{The German school and the school in Linden}

The German school system is public, although there are private alternatives for those who wish and can afford them. Each Bundesland (state) is in control of and responsible for its own internal school policy and finance, although with noextreme deviations from federal laws and regulations (Baumert et al. 1984, Schultze and Führ 1973). Curricula, pedagogical policy, the hiring and firing of teachers differ among the Bundesländer, so there is not a simple unity between them (Claessens et al. 1978). Differences are not great but are given significance in the political debates and struggles and for the parents of Linden in their choice of secondary school for their children.

Formally, school life begins the same for all children. They start off in the Grundschule, which usually comprises the first four school years. Thereafter various educational choices set in which open or close future doors of employment and careers. Up until the 1970s these choices were fairly definite, it was difficult to change from one form to another. Each school form led to a particular graduation. This has in the last ten or fifteen years to some extent been changed, so that it is no longer impossible to move from one form to another, at least in principle.

To 'not make any choice' is to continue from the primary school to the Hauptschule, das Sorgenkind der deutsche Schule ('the problem-child of the German school system'), as it is lamented by critics in the debate (cf. Baumert et al. 1984, Wünsche 1979). This school means that the children go on until the ninth grade and then leave school and enter some form of vocational school, Berufsschule. Where ambitions are higher and life somewhat different, children may after fourth grade go over to the Realschule, which after another six years of school ends with a 'middle level exam' which is a combination of theoretical and practical training with a view towards vocational specialization. The most distinguished choice is to go to the Gymnasium, which begins already with the fifth grade. Graduating from the Gymnasium, taking the Abitur, opens doors to any kind of higher education at universities. 
A somewhat different career starts when sent to the Sonderschule. Children who are considered in some ways incapable of managing the ordinary school - perhaps they have failed one grade more than once, they may be thought of as behaviorally or mentally retarded - are not accepted in the regular school. Teachers are not seldom concerned with one or other pupil who must be removed from school and instead start in the Sonderschule, die Dummen-Schule ('the dummy-school'), as it was sometimes called by people in Linden. Once in, never out, so the saying goes, but according to legislation this must not necessarilly be true, it depends on the reason for being sent there. But reasons may be difficult to understand for the pupil and for its parents. And reasons can also tend to perpetuate themselves and those who give them. At any rate, it is socially humiliating for a family when a child must go to Sonderschule. Yet on the other hand, all kinds of disorders are at different levels diagnosed by professionals - kindergarten teachers, school teachers, expert pedagogues, doctors - so quite a few children are at different times sent for longer or shorter intervals to alternative kindergartens and schools to retrain speech disorders, and behavioral or learning disorders. This means that it need not always be quite the social 'trauma' it may seem to be at first glance.

In some of the Bundesländer, neighboring Hesse, for example, there have developed school forms which are meant to counteract this closed hierarchical school system where children are stratified so very early in life. The aim is that all children should have the same shooling for at least the first six or seven years of school, even longer, and then part in different directions according to choice. This is the Gesamtschule, which is so detested by the CDU/CSU. The Gesamtschule has only been practiced to some extent in those states where the SPD has been in power.

The school in Linden has classes from the first to the seventh grade, and about 200 children attend. They do not all come from Linden; on the contrary, most of them live in other viliages. The Linden children, in turn, attend their school often only the first year, thereafter they are incorporated into the intricate system of school bussing. At the end of the $60 \mathrm{~s}$ a state reform initiated a reorganization of the prevalent school form in rural areas. Each village had had for several generations its own school and children of different grades were taught simultaneously. In Linden children had been divided into classes of three grades from the first to the eighth grade, whereafter most continued in some form of Berufsschule, 
vocational school in combination with employment. Or else work in small industry and on the land awaited, with no further schooling.

The school is organized in several levels leading to different kinds of final graduations, which now means that moving from one level to another is also leaving one school administrative section for another. The Hauptschule, the school form which is the most common after the first four years of school, also for Linden children, is located in Brücken. Already in the second grade, though, they leave the Linden school and go by bus to Steingrund. Linden does not have a Hauptschule, but in practice it lends classrooms to a neighboring village which does have a Hauptschule, but does not have room for all the classes.

What all this amounts to is a feeling of confusion and a lot of $\ddot{A r g e r}$, ill-feeling, between the many communities in the region. The school organization costs a great deal, the smallest villages are left with empty school houses and all children in the whole region must, often from the first grade, go to a school in some other community than that in which they live.

Costs are usually the main focus of attention when complaining about this whole adminstrative reform - who should pay for the repair of the school houses? Linden, for example, has hardly any children attending the school in Altheim, although they belong to the same school organization. So why should the people of Linden pay the repairs of their old school house? Did they pay for the Linden school maybe? The costs of transportation are great. The bus companies which take the school children are privately owned and there is one company, in Altheim, which almost has a monopoly. Their days are golden - and who pays? We do! Why should the Altheimers have our money? So, although Linden has a fairly new and modern school house with a small swimming pool even, the children of Linden only spend one or two of their school years in this school. Instead they take the bus every morning to, first, Steingrund, later Brücken or Städten.

\section{Sarcasm and praise: constructing Ordnung in school}

As I have already argued in previous chapters, Ordnung is a central idea and value in Linden thinking, and the teachers are convinced that Ordnung is something children must learn, it will not come 'naturally'. Thinking 
must be orderly and will become so only if order has been practiced materially, first of all, as in kindergarten. This means that a child must learn to keep his or her things tidy, each thing in its place, so that tasks, such as homework, can be accomplished neatly and correctly. Several means are necessary to attain good results in school and the learning of order is one of them, order being both a means and an end in itself. Praise is extensively proclaimed as essential to achieve good work. Teachers and visiting pedagogical experts will admonish parents to praise their children, giving them rhetorical phrases to use, and make them feel at fault for any bad outcomes of their children's school results. Such fault finding is a kind of ongoing argument which ideologically links person, family, school and the state into an uneasy 'whole'. From varying perspectives they can in turn all be to blame.

But praise is not all, it will become senseless if used without limit. Other methods are more implicit, encouraging or luring the children to imitate the work of their teachers, which to some extent coincides with notions generally held in Linden about learning as partly a question of imitation. Imitation places the adult in the position of a model (as I mentioned in chapter 1), a position which may be quite vulnerable, but which also reinforces the hierarchical relationship between adult and child. The child incorporates traits and capabilities of the adult so as to become the "complete person' (using Strathern's apt concept loosely, 1988a) the adult is assumed to be.

Frau Rasch also says that school work becomes poor if there is no order, and order the children must first learn at home. For example, neat, nice writing is a sign of orderliness, 'and some parents just don't understand that!' She herself is not a particularly orderly person, unfortunately, she adds, which has made her realize the need for order so much more clearly. 'In the society of today there is so much knowledge and there are offers that are so varied that if there are no principles of order it becomes impossible to gain any overview. Not even the most intelligent can manage this without durchgeführte gedauernmässige Ordnung ('thorough and lasting order')'.

A specific form of order in school is that of writing, both in terms of good, neat handwriting, and correct spelling and language usage, which amounts to what is called Rechtschreibung. Dictation is the main form of controlling the art of writing. Much time is reserved for this during the 
school year, particularly during the first four or five years of school. Rechtschreibung is in a sense the heart of all learning in school (even if critical pedagogues of today would not want to see it that way). Parents are also very concerned about it, wanting their children to be good at it. Mastering Rechtschreibung implies that other subjects can be mastered, and that the pupil can comply with given standards of learning. ${ }^{3}$

Rechtschreibung has its derivatives or forerunners in basteln and drawing in kindergarten, even in the Beschäftigungen, and it may also be seen as connected with the notion that children must answer questions with a complete sentence. All these activities have their standardized forms which the children must be able to master, otherwise they are thought of as not learning.

Frl. Zeiger, the third grade teacher in Steingrund, is about to return the dictations which she has corrected. The children are very excited and can hardly listen to her as she reminds them, papers in hand - a very effective way of underlining the suspense - how very important it is that they practice at home. One notices which parents really practice writing with their children and which just see to it that they do their homework, she comments to me. Practicing is as important as doing regular homework. This is not without problems though, since parents are often told to let their children work, practice, independently, they should not interfere. Yet they are criticized for not getting their children to practice enough and practice well. As one expert pedagogue said at a meeting, one should practice with one's child one or one and a half hours every day, and he lauded the work of mothers, 'mothers are the nation's assistant teachers', which many feel is not an enviable honor.

The papers are finally distributed, first to those who have received the highest grade. They jump up and down in delight and relief. The rest are given theirs with some comment about mistakes they have made. Some of the children are obviously worried and they all walk around to each other to see what grade they have recieved, comparing, talking loudly. One little girl has failed and is very unhappy. Her best friend tries to console her but she shrugs her off, hurt and angry. Those who have made mistakes must rewrite those sentences. Frl. Zeiger writes the sentences on the blackboard very, very neatly and the children copy.

This school day ends with Rechtschreibung. Frl. Zeiger writes three different capital A's on the blackboard, the examples taken from the chil- 
dren's notebooks. Which is the correct A? The children point and call out. All of them write an A of this kind in the air, after her. They are working with $\mathrm{A}, \mathrm{M}, \mathrm{N}$. Now what is important? The right tilt, the correct hook in the beginning, the ending curve - all details are important when writing!, she tells them. 'Now, let us all lay our hands flat on our desks, keeping all fingers straight. Then we try to move our forefingers only, then our middle fingers, then each following finger in turn. Then move all your fingers quickly over the desk as if they were running. Now keep your elbows resting on your desks and move your wrists nice and loosely. There, now you will be able to write nice and easy! We will practice A, M, N'. The children are each given a large piece of white paper to write on: A, M, N, again and again. Crayons are later used to fill in the lines with different colors. Frl. Zeiger walks around in the classroom, inspects their work, corrects, comments, once in a while appreciatively. The children work intensely and seem to enjoy it.

Order is not attained without effort, and it unavoidably gives rise to the problems of punishment and praise, which can be seen as part of the discourse on means and obstacles to learning.

Why is a child afraid of school? asks the Diplompädagogin ('diplom pedagogue') from Würzburg, invited by the Parent-Teacher Association to give a lecture in Linden, and she goes on to say that a child is afraid of bad achievements, bad grades. Teachers will often say that a child lacks the intelligence and that parents are too demanding. Through such überforderung ('over-expectancy') anxiety develops. A child needs constant recognition, and through praise a child will accomplish very much. It is difficult to always praise, but it is needed over and over again, even if the notebook has become messy, even if writing goes very slowly.

Her point is that when a child is praised it works better, striving for more praise, when it is punished it becomes aggressive and afraid of the punishment. And she asks them what kind of punishments there are in school. The teachers offer examples - a slap, although that isn't actually used anymore, they point out; the rewriting of certain tasks, repeating certain parts several times; being made to stand in the corner, or stand on a chair. The parents who are present say when asked that the children may get a spanking, or house arrest; they may be forbidden to watch TV or to go out and play; or their pocket money may be withheld. They all, parents 
and teachers, describe this in a manner which makes it impossible to know if this is what they themselves do or if it refers to something general which does not concern them in particular. This is not an uncommon way of talking about 'what people do', generalizing others so that nothing in particular about oneself stands out.

This pedagogue repudiates punishment and puts all her energy into the idea of praise. Punishment means that something is taken away from you, she says, namely love. She goes so far that it becomes difficult for the parents and teachers to grasp how they are supposed to act in practice. The pedagogue is moving along a continuum which is well-known to parents and teachers, but she is denying the dynamic of it, namely the tension between punishment and praise/reward, so well enacted in the Nikolaus celebration. Pedagogues will often underline the necessity of praise, inferring that punishments will of course occur and may be necessary, but punishments are seldom propagated. It is rather the bad consequences of leniency which will be brought forth, but to make praise into the sole concern is going too far and the parents and teachers present cannot really take her seriously, the idealized adult who only praises becomes too unreal, even in this kind of forum where ideals usually are the main theme.

What are you supposed to do? You can't praise a child who comes home with a failed grade! someone exclaims suddenly. Herr Bender, teacher, parent, and local politician, takes the opportunity to utter the usual condemnation of parents in general, that they scold and punish and press their children too much. But even he feels that there is no use in just praising. And one mother, Brigitte Grass' sister-in-law, cannot restrain herself from saying that children won't do things if one justs asks them. 'If I ask my daughter to finish her dinner she'll take hours but if I say 'damn it, now eat!' she's finished in five minutes!'. A few of the younger teachers agree that you just do not get any results sometimes if you keep saying bitte ('please') - and that is because they are not used to being kindly treated at home, Herr Bender speaks again. Some parents agree with him, others consider that the children themselves are the problem, that children demand punishment, that the child is to blame.

Frau Heim begins each new school year by telling parents of the support children need to be able to manage school, the encouragement and praise they need. Parents must take time for their children and not use force, which, she says, will get them nowhere. This is also how she speaks 
about the children's needs in conversation with me. Yet this seems to be a far cry from her overt behavior, for, as described below, she constantly yells at them and ridicules them when they make mistakes or do not understand. She very rarely finds reason to praise the children. One may perhaps dismiss this as either being an extreme example, or that she is lying, or being very ingratiating. That is, one may find little which reconciles the seeming contradictions between her statements and her behavior.

As far as her overt behavior is concerned, she is somewhat extreme, but her thoughts and actions are explained by her in terms understandable among her younger and more easy-going colleagues. Frau Heim sees herself as an experienced teacher who understands the needs of her pupils, she knows that children need firm guidance or they will learn nothing. But there are impediments to her ability to realize her educational goals. These are the parents' unwise tutoring at home, the pressure they exert on their children, but also their laziness and lack of interest in their children's work, and so in hers. The unintelligence of the children is another major impediment. Frau Heim considers that this is one of the most serious reasons for the children's inability to achieve. Given these obstacles there may not actually be any contradictions between what Frau Heim says and what she does. She shares ideals with the parents she quite generally can be so critical and even contemptuous of. That she sometimes flares up and gets 'a bit loud' is just her way, as she says. She does not seem to consider her actions as part of the social situation and so influencing it. Rather, the social situation is 'there' and the actors do not seem to be thought of as forming or being formed by this context. They enter it with certain prerequisites of 'character', and are in a sense at its mercy. This is one aspect of the notion about life as hard and the necessity of adjusting to its demands.

Praise, and love, in upbringing are indeed a necessity, as parents and teachers see it, but praise and love are not free, they are not given lavishly without expectation of something in return. Praise and love are used to get good results but demand good results to be given initially. Punishments help mark the boundary between the good and the bad.

Perhaps a more common daily way of interacting with the children, as a means of attaining results or just commenting on given results, is through forms of irony, ridicule or teasing.

The children here are mentally (spiritually) retarded in comparison 
with other schools, with city schools of course, but also with others in the countryside, says Herr Mann and shrugs his shoulders in resignation, laughs a bit. Ich habe nichts gegen die Rosentähler, es ist nur halt so ('I have nothing against the Rosentahlers, it just is that way'). In his deploring the intelligence of the Rosenthalers, Herr Mann aligns himself with a worldwide corps of teachers who incorporate in their own resignation and professional biography a certain amount of contempt for the world of young learners.

Herr Mann is about 45 years old, he has lived with his family in one of the area's smaller villages since about fifteen or twenty years. Neither he nor his wife are born in this region, although she is from another part of Bavaria. He is himself from Romania, came as a young refugee together with his brother right after the war, although not directly to this region. Currently, Herr Mann has the fifth grade in the Steingrund school, which means that the children are Hauptschule pupils. He used to teach in another village, but that school has been closed and now he is head teacher in the Steingrund school.

Entering his classroom of about 35 pupils one is struck by the noise, the liveliness and the seeming disorderliness. As Herr Mann moves about up front, preparing the maths lesson, he does not seem to care much about the noise around him. The children seat themselves, a few attempting to pay attention. His strong voice catches their attention without shouting and with a nod in my direction as admittance of my presence; we are all part of his disillusioned lesson. As he talks he distributes questions right and left, ignoring the children's raised hands, without pausing, expecting quick answers - questions and answers flow into his own talk - Herbert, hier vorne läuft der Film ('Herbert, the film is running here, up front'), he says to catch Herbert's swerving attention, without slowing down his pace, without waiting for a comment or a reaction.

Lessons change content, after mathematics comes Sprachlehre (grammar). There is an eruption in the classroom as papers with questions are distributed, there is to be a small test, then a sense of calm as the questions are discussed and to some extent explained. Sehen Sie, Frau Norman, he says somewhat jokingly and without paying much attention to me, was mir wirklich die Nerven kostet! Die können nicht einmal lesen was darauf steht! ('You see, Mrs. N., what really costs me my nerves - they can't even read what it says!'). Shortly thereafter, one of the boys has gone up to Herr Mann to ask him the meaning of one of the questions. Herr Mann con- 
fronts him ironically - 'and now what is it you don't know again?!'.

While Herr Mann's irony and teasing is more good-natured, Frau Heim uses sarcasm and ridicule, and irony, at great length, and more in line with notions of punishment. She is fairly unusual, but quite possible, in the extremity of her usage of this in that it combines with an open show of annoyance and anger.

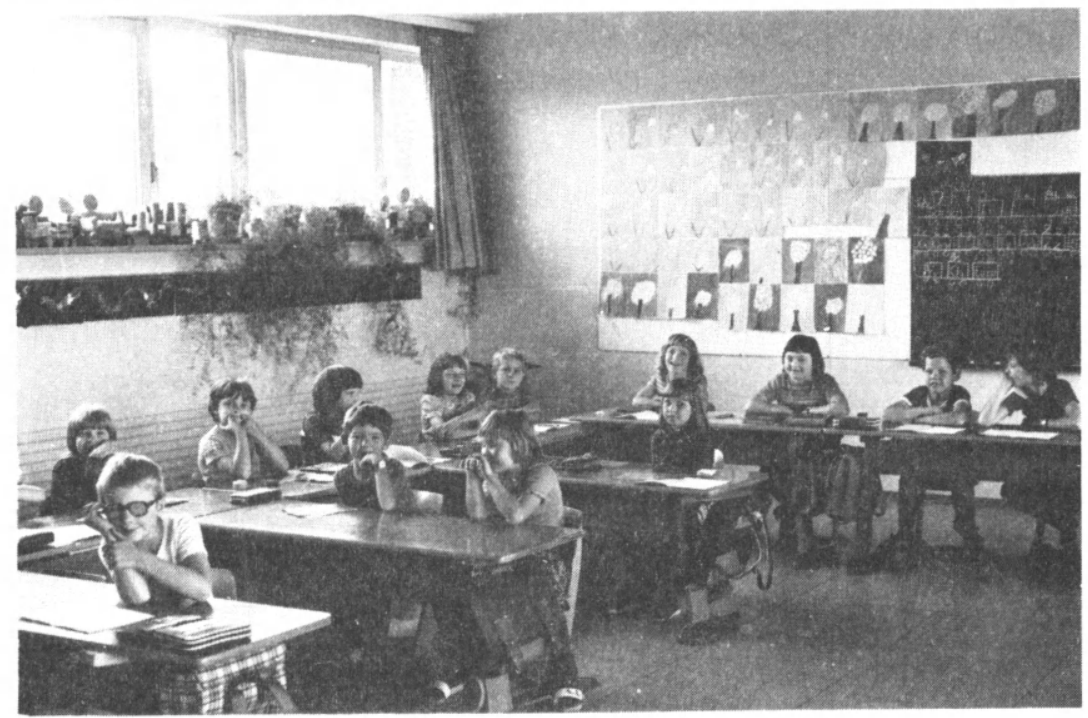

In the Linden school - the first graders in their classroom.

It is morning, the children have prayed in unison, crossed themselves and shouted the long drawn-out monotone greeting, Guuuteen Mooorgeen, Frau Heiiim! ('good morning, Frau Heim'). They all sit down and the lesson may begin. Frau Heim is having a science lesson, Sachkunde. It is spring and they are going to talk about the flowers in the meadow, their names. She asks the children what the different flowers are called and as they answer she writes the names on the blackboard. 'Not just the NAME!' she shouts at Jutta, 'we use complete sentences!' and Jutta repeats in a low voice the name in a complete sentence. Afterwards they are to write them in their notebooks, very neatly, sauber arbeiten ('work cleanly'). They look at pictures of the flowers and are to identify them.

What flower is this? she asks them and points to a white clover. 
Franz hesitates when he is asked. Don't you know?! she calls out at him, and he then says it is a dandelion. 'Do you mean to say that this is a dandelion?! Is a dandelion white, eh?! THIS is a dandelion, so how could this (clover) be a dandelion?! Can you answer that?!!' Franz stares at the picture and does not answer. There are no longer any hands being raised, everyone stares silently at the pictures being shown.

Frau Heim walks around in the classroom to see how the children are getting along with their writing. Wir arbeiten ohne Mund! she calls out, ohne Mund! ('we work without mouth', that is, no talking). She is very annoyed when the children have made mistakes and she can become quite sarcastic. Well, well, looky here, our Daniel hasn't been listening! she calls out to the class and as she continues she stops by Jan's seat. 'And what has Jan put together now again?!!' she hollers and punches his head, 'as usual he's forgotten to leave a margin!' she says to the class. She leaves him with no indication of what he should do about it now. She yells at them all to write faster, and she sighs loudly and irritably.

Was ist? Wer flehnt denn jetzt?! Der Walter?! Unser Heulsusse! ('What now? Whose crying? Walter! Our cry-baby!'). She is sitting at her desk, the children who have finished writing stand in line to have her check their work. Some of them giggle at her remark. Walter says that he doesn't know what to do when writing Steinklee ('clover'). Thomas, who sits next to him, tells him that that's nothing to cry about. After a while Frau Heim gets up and goes over to Walter. 'For goodness' sake, write it under here!! Can't you understand that?!' And she turns to the class to tell them about the silly mistake he has made. They look at her, but no one says anything.

The Wiesenblumen ('flowers of the meadow') recur time and again, also as homework. So ein Mist machen wir nicht zusammen! ('Such a mess - literally, dung - we do not make!'), she says to one of the children as she goes around inspecting their homework. 'Daisy, Gänseblümchen, is written with a capital letter! (as are all nouns in German) She doesn't know that!' Those whose work is satisfactory she does not comment, she only signs the page with a red $\mathrm{H}$, for her name, as proof of it being correct.

When it is time for a grammar lesson, the flowers of the meadow are again put to use. Nouns and adjectives. Adjectives are 'how-words', Wiewörter, she tells them, they tell us how things are - blue, green, small, big. Wie bist denn du eben?! ('How are you then?!'), she suddenly hollers at Martin. Tired, Martin answers. 'Yes, you are tired', and she writes it on the board 
as an example of an adjective. 'And what can we write instead of tired?' Lazy! the children cry. She laughs, that's right, lazy! And the children also laugh. Frau Heim appreciates that the children have 'a sense of humor'.

Through the irony, the sarcasm, the sighing and the shrugging of shoulders a certain comical atmosphere can be created, as in Herr Mann's class, which seems to contradict the expectation one may have of the strictness of German school education, and of child rearing on the whole. All is not 'fearful discipline', but neither is it just the opposite, as Frau Heim exemplifies. Teasing, irony, ridicule, what are also seen as forms of humor, must be understood in relation to the demand for order and obedience or subordination. There is a great ambivalence at work in the relationship between adults and children. It is a reiationship which can be emotionally close and demanding, and it is assymmetrical and uncertain. It is not the subordinate who stages the joking, but the superordinate. In a book like Max und Moritz it is, initially, the other way around, to the general enjoyment of both parties of readers, adults and children, but in the end the mighty adult does win anyway. Humor may be an alternative way of controlling. The sarcasm and the irony, which is at least sometimes intended to call forth laughter, disarms the child at whom it is directed. It is the superior who makes fun of the inferior. Not until the person has acquired the ability and the status, that of equality or superiority, can he or she answer back.

Humor or jokes may also invert hierarchical relations which otherwise may not be questioned. This is part of Fasching ('carnival') hilarity. But even on such an occasion the subordinate may end up being the one who is joked the most about. Being in a subordinate position is somehow silly, one is dependent, but as adult one is never only subordinate in relation to everyone else. And one can once in a while take the opportunity to laugh at the whole hierarchical spectacle, and at oneself. But a child is always in a subordinate position yet not unambiguously, for a child will be an adult. The temptation to joke or make fun of this in-between being is perhaps quite strong sometimes. ${ }^{4}$

Teachers may complain that they no longer are allowed to give a pupil physical punishment, not necessarily because they would use such means, but because they themselves may feel that they are being more controlled, and less protected. It may be that ridicule and irony have to some extent replaced physical punishment, thereby reinforcing a generally appreciated aspect of the interactive discourse in Linden. 


\section{Asking and answering questions}

Frau Heim asks the class 'what flower is this?', pointing to a clover. Hands start waving almost before she has finished the sentence. The children moan and groan 'ah, ah, ah!', waving frantically. Frau Heim's eyes scan the children and some of the hands drop as her gaze closes in. When she has decided to let one of the children give the answer one can hear several of the others sighing and moaning loudly as they hear the answer, as if they were greatly frustrated at not receiving the chance to answer. They hereby assure Frau Heim that they really know the correct answer.

In all of the classes I visited this was the common behavior, but more or less pronounced. Upon hearing this moaning and groaning, some teachers will ask, ironically, who has got a stomache ache, which sometimes subdues the noise for a while. Frau Rasch's class in the Steingrund school had driven this to great lengths, and she took her very good time before deciding on whom to bestow the question. The noise could at times become quite loud and the waiting almost painful.

Fritz is a boy in Frau Heim's class who makes intense use of this system. He will immediately raise his hand without ever seeming to have to reflect over the correct answer. As Frau Heim starts scanning the room he keeps waving his arm, moaning very loudly, but as she comes nearer he retreats, lowers his arm more and more, almost hiding it if necessary until her searchlight has passed on, whereafter he starts off again. Once in a while he does get the question, but more often than not he will then have 'forgotten' the answer. He sighs heavily over his own forgetfulness, fretting at himself - 'I had it on the tip of my tongue and now it just slipped away!'. Frau Heim does not bother much about this, after a very short pause she will just give someone else the question. If he does not get the question he is the one who most emphatically can, for example, slap his knee in seeming disappointment at not having been allowed to give the correct answer which knew he so well.

Frau Heim may, like Frau Rasch, take her time before deciding who will get the question, but more absent-mindedly or else on the look-out for some specific child. She is this year prone to turn to her two grandchildren, not so much to favor them as to sharpen the control of them. Getting a weak or incorrect answer she may scold them with 'if you don't do better than that Oma won't give you a birthday present'.

Attempting to answer a question is a gamble. Giving the wrong answer 
may trigger a sarcastic remark from the teacher. Frau Heim will more often than not feel inclined to sarcasms - 'So?! You mean to say that seven 10-Pfennige (pennies) make 80 Pfennige, is that it?! Have you all heard?! My, my, how we can count nowadays! It's eight, of course, you dummy!!' The other teachers will not be so extreme, but they will often find some fitting remark.

For the child to ask a question may also be a gamble. Asking about something which has already been told, taught, and is expected to be known, will almost always make the teacher sigh, give a counter-question as to the capacity to listen, or some other more or less ironical/sarcastic comment. Frau Heim may become downright angry, and in her class a child may start crying for fear of asking and the humiliation of not knowing how to continue a given task.

But asking, seen as a more good-natured form of exchange, is something the children are eager to engage in. The children find out what kind of questions it is possible to pose without being reprimanded, ignored or teased. As Frau Heim's class at one time was copying words from the blackboard, they were working quietly when some of the children asked how to hyphenate a certain word, and Frau Heim answered without any show of irritation. They had not yet learned how to hyphenate, she could not expect them to know, which she also told me, they had to ask. And they excelled in asking to the extent that one could wonder if they were hyphenating all words, the same words were bouncing from one end of the classroom to the other. She hushed them a little when they became too loud and eager, but she was quite patient the whole time. The atmosphere in the classroom will at such times become quite lively, the staleness of boredom and fear subsides and the children speak their more well-known German and not the drawn-out complaintive German they often use in relation to the teacher.

What is going on when Frau Heim is being bombarded with questions about hyphenating? What is the 'meaning' of asking and answering questions? As Goody says, "What is the relationship between the kinds of messages which questioning carries in a given society and constraints on questioning?" (1978:39). Asking and answering questions in school is not exactly the same thing as at home, among friends or strangers, but perhaps they should not be seen as completely separate. ${ }^{5}$

Both the children and Frau Heim are enjoying a moment of relaxed 
control, playing with this rhetorical situation. The pressure of not asking and of avoiding, or competing for, her questions disappears. By continuing to ask they are stalling for time, prolonging this happy affair. There is an aspect of deception or pretence in the whole interrogative process in school, which also these 'good questions' reveal. The 'good questions' only divulge an acceptable lack of knowledge, and they do not question the authoritative knowledge of the other, the teacher. The children may admit to their lesser knowledge, but they may also use this to push the teacher - as if thinking 'she said it's all right, then she sure has to show it'.

Questions and answers have to do with pretending and hiding, and notions about lying. As I mentioned earlier, hiding is a recurring element in everyday life - hiding behind curtains, hiding rooms from visitors to one's house, hiding dirty dishes from view. It is a way of drawing boundaries and of controlling that which is to be put on display. 'Reality' is something one should know about and adjust to. At the same time people have to cope with ideals about the person which are difficult to live up to and which may reveal gaps of knowledge and capabilities of good and right conduct. In view of this it will probably seem necessary to keep certain parts of oneself, whether thoughts or deeds, hidden from others.

Questions and answers constitute a powerful discourse on uncertainty and authority, a manipulation of both, which to some degree resembles the discourse about freie Phantasie ('free imagination') and what I here call copying, that is, attempting to resemble the teacher's work as much as possible. Copying is certain, predictable, authoritative, and collective, whereas imagination, or what may be called creativeness, is more or less thought of as the opposite. Yet copying is not unambiguously admired, for creativeness is a manifestation of individual uniqueness and 'sensitivity', which is admired. ${ }^{6}$ But it also has its dangers. Perhaps like 'wildness', or 'energy', it is tolerated, enjoyed, sometimes admired, but it can strain boundaries if it appears in the wrong place and it is then punishable, as 'bad' imagination would be deplorable. Teachers are caught in a fix just like parents. Both parties want good results from the children, since this also reflects back on themselves, so copying, whether in drawing or writing, unavoidably becomes an esteemed aspect of learning. One mother ironically commented on this phenomenon when her daughter came home with a Christmas calendar she had made in school, 'they probably all look alike from north to south (of Germany)'. She disliked everything being made 
so predictable in school, like the Mother's Day poems children were to surprise their mothers with the year before; they were all the same, 'and probably recited in the same manner'.

It is difficult to say much about what the children experience in school, but my feeling was often that they were very bored. Restrictions and expectations are so engulfing that the scope of emotional and intellectual movement becomes very small for the children. There is no room for pleasurable fantasizing. The control in the classroom, of which the manner of praising recommended by Frau Heim and the other teachers is an essential part, makes learning very circumscribed and boring. The effect of strictness and ridicule may not necessarily be just anxiety, but also boredom. That the children reveal so little of themselves may perhaps even make the teachers bored and so annoyed with the children.

The usage of time falls within this realm of restrictions. Several times a day the children are admonsihed to hurry, to finish in time, ahead of the others. This is emphasized whenever the teacher calls out aufräumen!, put your things in order, clear your desk, and this happens many times a day. As Frl. Zeiger usually says it: Aufräumen! 'I want to see who's first with getting the desk in order! Come on, one, two, three!' With great speed and much bustling the children start putting their things away. She waits in deliberate silence until everyone is completely finished and sitting quite still, which despite the show of speed may take some time. Aufräumen turns out to be the central activity it also is in kindergarten. It implies to hurry, as if time were scarce, whereas aufräumen in itself can be a very time-consuming activity. So there is a constant push and pull with time and the children are hurrying so as not to have to hurry, or rather hurrying to wait (cf. McDermott 1977)

\section{Obstacles to learning and the problem of blame}

Off and on during the school year parents are summoned to class meetings, or the school, sometimes the church, arranges more general meetings for parents and teachers. During all such events certain concepts keep recurring which appeal to concerns about the children's ability to learn.

At class meetings one or two of the teachers will preside up front as the parents, mostly mothers, sit at their children's desks. The atmosphere is formal, everyone is dressed a little bit 'nicer' than usual on an ordinary 
workday, and there is little talking among the parents. The meeting is well planned beforehand by the teachers and there is no doubt that they are in charge. The teachers seem to be tense and as if they have the feeling that parents are critical of them and their work with the children. They will at times explain their actions in terms of precautions against potential criticism from parents. Teachers keep their distance and it is clear that parents are not on home ground. Actually, it is the parents who are criticized on these occasions, not the teachers, but in a general way, no one is pointed out.

The parents listen and keep to themselves most of the thoughts they may have. For although parents are invited to ask questions and take part in a discussion there is actually very little encouragement along this line from the teachers. Teachers often seem to suffocate questions and comments by giving abrupt, yet wide-ranging answers with dismissive explanations, so that only questions which already beforehand imply agreement are really accepted, or encouraged. Not so unlike certain aspects of the staging of questions and answers in Frau Heim's class.

At a class meeting, Frau Rasch, who now has the fourth grade, takes up the subject of Konzentrationsstörung ('concentration disorder'). She reads parts of an article dealing with concentration disorder - 'it has become a regular epidemic!', and she and the other teachers know what that means because there are quite a few children in the class who have this disorder.

Konzentrationsstörung is a fairly recent concept, a 'scientific' concept, which teachers, psychologists, pediatricians use to explain what they consider to be an increasing inability among children to learn in school, to manage school work. It is a professional term which parents do not use, or rarely, although they often meet it phrased as a severe problem which it is their own responsibility to solve. Teachers see it as a new phenomenon, at least in the sense of being so widespread. They will, when talking about this 'disorder', refer to unspecified psychological studies to legitimate their own observations of different children and to underline the seriousness of the matter. Such studies also seem to offer explanations which are easily rephrased in moral terms, and the scientific status assigned to the views wards off any criticisms, or transgressive questions, from parents about the school situation at hand.

No one says a word or makes a move. Frau Rasch goes on and admonishes the parents with words they have heard since their first child 
started first grade - 'you must give your children recognition and praise. You must tell them that they are doing well and that they can do it even better next time'. It is also very important that they eat a good and noursihing breakfast, and it is essential that they are given a place to sit and do their homework undisturbed by siblings and activities going on in the house. ${ }^{7}$ As a visiting pedagogue once pointed out, a child should not be distracted and leave its school work unfinished, start looking out the window, or listen to a record. 'Distraction means turning one's back on a problem', and that means that a concentration disorder will develop. At the end of this, in reality much longer talk the parents are given a list of words to use as a check on their children's vocabulary and to use in training them, because 'it is obvious that the children's vocabulary is too meager'.

Experts from a university or a medical clinic are once in a while invited to give lectures, which emphasize the urgency of education and the hierachical order it entails. At meetings with outside speakers, questions and discussions may be somewhat livlier, own experiences and opinions are more openly hinted at. But even if the speaker makes ample allowance for 'how things actually are', that is, recognizes that 'problems or difficulties are a part of family life', the tendency is nonetheless that of underlining how things should be. This is not always done in terms of direct advice, but in terms of explanations and admonishments, recommending certain forms of behavior, discouraging others - and all based on the presumed scientific status of the information given. Parents are often presented (and 'condemned' - sometimes quite mildly, sometimes more severely) by the lecturer or teacher as being too expectant, too concerned about 'good resluts' from their children. And again - 'children need positive support, consistent rules to follow, praise and recognition, both from school and from the home'. The school is added when the speaker is not a local teacher.

'Now more than ever it is vital that we consider problems of Erziehung', one pedagogue from the university of Erlangen starts his lecture, thereby attaching himself to a long line of German pedagogues who have deplored the threatening social catastrophes and seen a major, or sole, remedy in the methods of upbringing and education of the young. This standpoint implies conceptions of blame and responsibility (Schuld), an aspect of social action which is generally held to be significant. Whose fault is it that things go wrong? Who is to blame? The main conflict is that between 
family and school. Among teachers, parents are said to demand too much of their children, among parents it is the other way around. Parents do not care enough about their children; there is too much leniency it is sometimes proclaimed, but 'there is also too much punishment'. Children must be praised, rewarded, loved, the lecturing pedagogue says to his or her audience. As it seems, parents are held to be more or less incapable of this, according to much expertise. Parents may agree about this, since no concrete cases are given, examples are general and abstract and one is usually talking about others.

References are made to developmental and cognitive psychology, sometimes psychoanalysis, and sometimes even ethnography. The pedagogue from Erlangen university tells his audience of both parents and teachers that from the start in life a child strives to learn. This goes back to the first period of nursing, the mouth is then the center of knowledge and the mother/breast is the good provider. This process of nursing/giving and the subsequent necessary frustrations are the prerequisites of learning. The Arapesh of New Guinea, he says, nurse their children for a long time and the Arapesh are therefore happy and satisfied, but they are also without any striving for Leistung (achievement). The Germans are often spoken of by people as being too achievement oriented, pushing the school children too hard, but being like the Arapesh would hardly be an ideal. The pedagogue alludes to the ambiguity of the balance between an indulgence in rewards, praise and sweets, and demands for achievement and the necessity of punishment. The process of learning implies, as it seems, a certain amount of unhappiness.

If parents are held to demand too much of their children, as the principal and enlightened parents such as Frau Bender say, not really seeming to include herself among these, other parents are more inclined to blame 'society', or the environment, which often means television. Actually, parents and teachers are able to meet, ideologically, at this point for teachers, more than parents, will complain about television. Children are over-stimulated by television, they watch too much and parents are incapable of saying 'no' - they watch too much themselves for that matter. Too many distractions and demands impede learning. Erziehung is of the utmost importance here, which places the family in the center. Through Erziehung one can accomplish very much, stimulating the ability to concentrate. As parents, people are caught in a trap, they are admonished to take part in 
the children's learning, train them at home, help them when needed, but not too much lest the children become too dependent. And they should not demand too much of their children, but praise them.

Teachers give descriptions of the ideal type family and it is difficult for parents to go against such descriptions, since they have no reason to disagree with them - but they also know how things are at home, but that is another matter and not something to let on in front of teachers and other parents. And teachers, even though parents themselves, are not set on divulging their own problems, worries and mistakes. They are more apt to present their own situations and ways of acting as exemplary of their ideals. In that way they stand out as model persons for others to learn from, not individuals to question or criticize.

Parents always take a risk through their children - the risk of being seen, made public. Their children's accomplishments are interpreted as a reflection of their own behavior, ideas, or even genetic make-up. Yet this latter no one will seriously take upon herself or himself. Veranlagung points into an unknown distance as far as parents are concerned. Teachers, on the other hand, are more prone to consider the biological now, when it is applicable to the situation. So, actually, teachers and parents encompass a common set of ideas, generalizations, but do not use them simultaneously, and their terms differ, as do their social positions in the different situations where they meet. The parents are at stake through their children, the teachers through the parents, but the teachers must also answer to their superordinates and in the last instance, the state, which grants them the secure status of Beamte (civil servant) if their loyalty is reliable.

\section{Ordnung and the problem of difference}

The construction of Ordnung is a fundamental concern in Linden, but its attainment is wrought with difficulties. One such ideologically essential difficulty is the managing of differences, defining and explaining them. If Ordnung is a problem of unity and wholeness, are then differences an obstacle to this striving for order? I shall consider this particular problem of individualism, which hails equality as one of its vital values (cf. writings of Dumont and Kapferer already mentioned several times), through examples taken from the religious and sexual education in the Steingrund school. Certain topics in the curriculum are considered to be more con- 
troversial than others, namely those concerning 'religion' and 'sexuality'. I think that part of the controversiality lies in the problematics of coping with and accepting differences. There is an urge to redefine differences into sameness, which is also a way of defining order. This is in turn related to the ambiguity with which order is linked to notions of equality and freedom.

It is time for a religion lesson in Frl. Zeiger's class. She gives one such lesson a week, the priest from Altheim comes twice a week and has religion. She often reads a short story from the religion book, and these stories always have a moral mission - to be good, well-behaved, considerate, generous, helpful. This time it is about a small South African boy, a black boy, who has lost his parents and is walking around looking everywhere for them. As he is searching he keeps running into prohibition signs directed at black people and this makes the poor boy very unhappy. The moral of the story is that alle Menschen sind gleich ('all people are the same, alike'), and so it is not right that he be treated badly. It is only skin color, language, looks, dress and food which make people differ. The children listen without comment, at times disturbing with their internal chatter, and Frl. Zeiger hushes at them, sighing.

Much of the religious education is of this character, that is, stories about children who have run into difficulties and the point being that the children see the moral - to forgive; that we are all alike; that bad behavior may hide unhappiness and loneliness; and so on. The children are asked to place themselves in the other's position, to connect their own experiences to the situations described. It is constantly an appeal to how things should be and what feelings should be felt. Teachers and pupils may agree on how things should be, but the practice of everyday life tends to separate ideals and experiences; ideals are held forth to be adhered to but ordinary experience is not worth so much, unless it is reformulated into a clearer demarcation of good and bad. The stories are used as models and the children must identify with the idea of Vorbild rather than with the complexity of the content.

Teachers think that most parents would, if not before, protest if religion lessons were diminished, if they suspected that the children were receiving an inadequate religious tutoring. Judging from utterances on different occasions, people of Linden, particularly those who have school children, are concerned that the children are not only made aware of the 
stages of the life of Jesus and the functions of the church, but also of the necessity of being a 'good believer', to abide by the rules of the church. It is partly through 'religion' that children are thought to be brought to good conduct. This does not mean that all parents are stern believers or faithful church-goers, but what it does mean is that no one is prepared to take the risk of declaring a non-religious stance. As long as children are children they are not to be let on to the potential doubts of adults, which could jeopardize the morality of the child and the family's reputation.

Most teachers are not particularly fervent believers, some do not go to church regularly - or at all - something they then share with several of the parents. But this is managed discretely, it is nothing a teacher declares to the children. Teachers who are caught in this dilemma are relieved to be able to live in another village than the one they teach in, so as not to be constantly observed and feel controlled. There is one point where these diverging feelings and opinions converge, and that is the question of atheism - no one, believer or not, will support any atheistic tendency. That is taking one step too far, actually declaring non-belief, renouncing God and the Holy Mother. This carries with it an unknown risk, on the social scene, and ontologically, leaving the field open-ended and potentially destructive. It is through the medium of religion that morals such as humility, charity, kindness, loyalty, can be made universal and indisputable.

The other stumbling block in school is that of sexuality, sexual education (which goes under the name of Aufklärung, 'enlightenment'). What should teachers tell the children? The question is not only a local but a federal issue. At least in Bavaria protests have been voiced from both politicians and parents about sexual education in school. According to the curriculum the school is to give sexual education already from the first grade. But teachers may refuse, which, for example, Frau Heim always has, something many of the teachers sympathize with. Many CSU-politicians felt that sexual education should not be taught until the third grade and that parents have a 'natural right' to decide if their children are to receive sexual education in school or not. 'School must cooperate with the home', they would proclaim.

Only 'biological facts' should be taught in school without any valuation. The idea is that the school informs parents about what the children will be told, films that may be shown, written material used, and so on. In Steingrund, Frau Rasch and Frl. Zeiger are obligated to have a meeting 
with the parents about their children's sexual education, to receive their acceptance of it. The two teachers are extremely well prepared for this meeting, knowing that even if most parents accept that there is some kind of sexual education in school, a few do not. For some parents there is a feeling of relief that the school takes it upon itself to teach about sexuality - this enables them to avoid the subject more easily at home, they are not burdened with having to talk about it. They do not have to give their own versions of it, in this way it resembles the problem of religious doubt.

Frau Rasch gives a kind of lecture on children and sexuality, being very well prepared and not able to be caught off guard by any of the parents should they wish to try. She is, as it appears, very well-informed and quite outspoken as she talks about the child as a sexual being and so a part of society. There is then a seeming affirmation of the child as sexual, and of sexuality as 'societal'.

Children are early in life sexually curious and take pleasure in their bodies, she says, and a small child masturbates and should be allowed to do so. Children are brought up as sexual beings in the family since this development starts off so very early; so what becomes of the child's sexuality is very much dependent on the attitudes of the parents. The man and the woman have different kinds of (sexual) feelings, she maintains, and men and women play different roles in the family and outside of it. It is then to tolerance and Liebesfähigkeit ('fitness/capacity to love') that parents must raise their children.

She speaks about 'openness', that one must as parent dare to show oneself naked in front of one's child - which she does herself. She also undresses in front of the girls when they have gymnastics. 'At first there was a lot of giggling, even amongst the girls themselves, but this has all come to a stop now'. What she is saying here is that nakedness, sexuality, is very natural and nothing to be astonished or ashamed about once one realizes that there is no longer any reason to make such a fuss about it, be embarrassed or shocked, or feel indignant. As a reminder of the inconsistencies in this matter she points to the fact that 'pornographic pictures are shown all over the place, magazines of this sort lying around in the homes even, but a woman who does not wear a bra is considered obscene!' Now that is just plain absurd, she thinks. 'All these sexual taboos must be broken up', but she also wants to underline the necessity of learning tolerance. She is not at all pleading for some kind of 'free love' or an 'unconventional 
life', she just wishes to mention to them, remind them of the prejudices, the taboos, which flourish and the difficulties they create. ' $80 \%$ have sexual intercourse with the lights turned off', and to her that is quite revealing, 'people don't even dare appear naked in front of their wife or husband, even in a situation like that they hide themselves and their feelings'.

The parents sit very quietly and Frau Rasch keeps on until she comes to the question of sexual education in school. She has managed to prepare the ground quite thoroughly so that no one seems particularly inclined to utter any disagreement about her 'sexual modernity'. She is, for all her seeming outspokenness, quite general about sexuality and sexual habits, partly basing herself on some 'scientific study', never really appearing to be speaking about anyone present, not even herself even though she mentions some of her own practices, but all the time in a kind of model-term, making herself into a Vorbild.

As all of those present at the meeting had expected, Herr Klemm does question the whole idea of sexual education, stating that some children may be shocked if they come from families where such things are not talked about - 'there may also be some children who have no interest in such matters', he adds. None of the parents comment Herr Klemm's viewpoints, some smile to themselves at his last comment. Frau Rasch is relieved that his protests are so mild, and she assures them all of her discretion. She does not allow nicht gesellschaftliche Wörter ('non-social/ societal words') for sexual organs and the like. What she does underline, she says, is that people are different - 'some people are black, others white, yellow, or even red, and some are Männlein (dimunitive of men), others are Weiblein (dim. of women), and of these differences we must learn to be tolerant'.

The idea of tolerance is developed in the religion lesson, where acceptance and forgiveness are stressed in the stories told and the morals drawn from them. The conclusion is that we are all alike, our differences are only superficial, therefore forgivable, for being different does not really seem to be much of a merit.

Through the religion and sexual education lessons, problems of how to understand and define difference come to the fore. Fundamental for the educational issues that are central in today's German debate, as in other Western nations, are notions about democracy, freedom, and equality which I take the term Chancengleichheit ('equal opportunity') to imply. These are 
values programmatically adhered to and which children must be taught so that they are able to participate in the maintenance of the good social order. But the problem remains how to explain these overarching values in relation to social experiences. How are notions of sameness or likeness and difference reconciled? Obviously there are all kinds of differences between people, some are easily observable, recognized, known; others are less known and more imagined. This may also be said about likenesses, they are 'real' and they are imagined.

What appears in the lessons is that in a sense, differences are ideologically tolerated only as long as they do not really 'make a difference'. It is not 'different differences' which this ideology of tolerance accepts, it rather requires a redefinition of difference into sameness. In a way it is not permissible to be too different, for 'reality' is after all not just any kind of reality, but one that is imbued with the ideals which make reality real to people of Linden.

This is not just the makings of the Lindeners, but relates to a more encompassing social world in which they live. The somewhat hierarchical values of order and unity collide with the notions about the free and to some extent unattached individual. What Frau Rasch says about tolerance of differences, and what is brought forth in religion class by other teachers need not lack a sense of compassion for others and a wish that the world could be a happier place to live in, but as it works they are caught in a 'modernist trap', if I may loosely put it thus. To be blunt, one could say that Frau Rasch is not tolerant of difference, other than in her redefinition of it into the idea of 'humans are all alike' and this has the underlying assumption that humans be all alike on certain terms, in this case making them into good Lindeners, or Germans. There is no other world one can experience and really know about than one's own, yet Frau Rasch must cope with being an enlightened and modern person who has access to information about others she has no knowledge or experience of. To understand this, and teach about her understanding, it must be transformed into that which is like herself, the world she lives and feels she knows about. My point is not that someone like Frau Rasch is lying or manipulating, rather she is fusing to some extent with Western/Christian notions of universalism and with the workings of German society.

The complex process of learning as it develops in school works on this theme of order, which is already prevalent in kindergarten. The little 
'bead' pupil of whom Herr Pfarrer Kreis speaks, ideologically indistinguishable from all other beads, moves within an Ordnung for which it is individually responsible. The individual child's learning achievements are signs of the child's willingness to understand and subordinate itself to this order. But children are not expected to comply at all times and in all respects. Children are felt to bear within them a store of energy, and uniqueness, which is both the prerequisite for order and a danger for its maintenance. If children must distinguish boundaries, adults must first draw them. Frau Rasch's plea for samenes is one such attempt, from her modern vantage point.

Certainly peoples construe their worlds through the many ways of ordering - classifying, distinguishing differences and similarities, placing themselves in relation to this experienced and non-experienced world. But the idea of order in itself is not always the central point in this construction work, order as a stated goal, its 'own content'. However, as I have tried to argue, it carries connotations beyond its seemingly observable aspects. Ordnung is a 'key symbol', part of an ontological concern. This gives notions about the necessity of learning, as about the forming of the person, great force. In practice, however, nothing seems quite as clear-cut and, as we know, 'culture' is a continuous argument. 


\section{6}

\section{Encompassing the individual: claims of the church}

The church lies in the center of Linden, as it may be said to do in the lives of Linden people. This is not because they all are unproblematically religious, but because the church is an integral part of their social life and their sense of being Linden people. And it has a pre-eminent position within the field of upbringing. The conflicts this gives rise to do not necessarily contradict this assumption since conflicts and ambivalences make people constantly keep up a discourse about the lives they live.

The church is a marker of time and space, an explicator of the routines and crises of social life. The year is divided into smaller or larger units through a variation of rituals, processions, festivals, meetings and seminars, of which so many are sponsored by or related to the church. The yearly cycle of seasons and feasts provides enactments of the Christian calendarium and the local interpretations of these with all their additions and deviations. Time is a re-telling of events relating to the life of Jesus Christ, of which the most important are Easter and the preceding period of Lent, Whitsuntide, and Christmas. Commemorations of the nation-state are also brought into the realm of the church, for example the Volkstrauertag ('national mourning day'), when those killed in the World Wars are commemorated. And in slightly disguised form political messages are given in so-called Hirtenbriefe ('pastoral letters'), admonishments to vote for CSU.

More than $90 \%$ of the Linden people, according to municipal statistics, are registered members of the Roman Catholic Church, the rest being 
Protestants. This is the case in almost all parts of the region, although certain bigger communities have a large enough Protestant population to sustain a Protestant church, such as in Brücken. The Jewish congregation is all but extinct. There are some Jews living in the region, primarily in the bigger cities, but the Brücken synagogue was burnt down during the pogrom of November 9, 1938 and has not been re-erected. In the towns and cities live immigrant Muslims, of whom those from Turkey are the most numerous, in all of Germany. Lindeners have no contact with these people other than at their place of work.

The church has various links to the family, kindergarten and school, as well as with local politics and the free associations. During earlier historical epochs these links were of a more encompassing kind, but the church still retains some of its omniscient demands, and in Linden there is much talk about 'going to church', thus summarizing the problem of the relationship between belief and action and the position of the church in the social and ideological world.

Although this chapter deals with varieties of church life and often comes to focus on the activities of the Herr Pfarrer as a prominent agent of both 'community wholeness' and 'modernity', it would be misleading to regard the church as at all times the most important context within which Lindeners associate and think. Germans are known for their prolific associational life, Vereinsleben, and this is applicable to Linden as well, but it still receives little attention in my description. Since my focus is on the more explicitly educational endeavors of the Lindeners and the main institutional worlds which are created in this vein, seeing how the children oscillate between them, the church stands forth as a more significant event than the garden association or the voluntary fire corps, or even the Musik and Sportverein, although these latter two receive more and more room in children's lives the older they get (as was briefly exemplified in chapter 4 by the Nikolaus celebration). They do not replace the church but operate side by side with it, albeit sometimes quite antagonistically. This applies especially to the relations between the Sportverein and the church, which does not deny the fact that some board members of both are politically and economically intertwined.

The Pfarrer has lived a few years in Linden (replacing the old pensioned and not so active priest who had been in Linden for many years), having spent some twenty years in a parish not so far away. He seems 
intent on setting his mark on the development of Linden, appearing as a kind of entrepreneur. $\mathrm{He}$ is an outsider to Linden (as is common among priests), he participates in most every aspect of Linden public life, from church events to sports events to the fun of Fasching, and he is politically forceful, using the instruments given by the church. He has claims on being a 'traditional authority', yet he strives to be modern and come to grips with the times through organizing manifestations of Linden unity. Many find him and his closer associates and parish board members too active, disliking his hegemonic pretensions. But it is also felt by many people that he contributes to make Linden into a livley community, helping to give it a prestigious reputation. As I use the church and Pfarrer Kreis in my description they represent or summarize certain possibilities of action and thought in Linden which are both 'good tradition' and 'modern development', addressing issues which are vital for many Lindeners, the relations between the individual and society epitomized through the idiom of Erziehung.

\section{Believing and going to church in Linden}

Als Kind muss man in die Kirche gehen! ('As a child you must go to church!'). That is just the way it is, as one young mother says, and feels that she has no reason to give. Why her son has to go, why she had to? She never asked, she says, she just went, and now she just sees to it that her son goes. He protests, macht jeden Sonntag ein Theater ('makes a big show of protest every Sunday'), but to no avail. That is the way children are brought up, that is all there is to it. She refers to persons in authority outside the family, teachers, the priest, as a kind of noncommittal motivation. One has a reputation to hold good. Before teachers would check up on the children, ask who had been to church last Sunday, who had not. 'It's not like that anymore, teachers don't bother about it nowadays, but the Pfarrer certainly does', she continues. You are not respected if you do not go to church, is her view, which she shares with many others. But her husband refuses, he does not think that the Pfarrer has anything to do with his reputation, he says, yet he agrees that his children must go to church.

One must teach children to believe, for to be without belief is almost to be non-human. ${ }^{1}$ It is to accept evil and disorder, to be disdainful of that which is good. In many people's view belief is also a source of support, consolation and strength. An individual without belief is a lost person. The 
church is very much a concrete summation of this belief, so going to church is both acknowledging and learning belief, and a way of hiding doubt or disbelief, which is a problem for not so few. Still, this does not make every believer go to church, far from it. As Frau Stiller says, she hardly ever goes to church but she is not willing to disclaim belief. She is not from Linden, anyway, so she can do a little bit more as she pleases, she thinks, which other in-married women may interpret in a contrary manner. As long as she lived at home with her parents she was forced to go to church every Sunday no matter if she got home at five o'clock in the morning. If she did not go her father would beat her. It was not enough with Sunday Mass either, she also had to go once or twice during the week. It all makes her want to choke. But she does see to it that her nine year old son is sent to church every Sunday, although without the heavy load of force she herself had to cope with. Many women excuse their husband's refusal to go to church by saying that they had to go so often as children that they have gotten die Nase voll ('the nose full'). This is often said in general about children, that one must be careful so that they do not get die Nase voll, not force them to start going to church every Sunday when they are too small.

Belief, doubt and disbelief are problematic to people and they relate somewhat differently to it. There is also the voiced or unvoiced acknowledgement that adhering to the rules of the church has something bothersomely traditionalistic about it. They are, after all, living in a scientific age and sometimes it is hard to swallow everything which the Bible or the Pfarrer has to say. Yet, not to believe is almost unthinkable, there must be a God, a divine power, a force, something, one cannot deny Christianity. It is best not to think about it too much, and definitely not let on to feelings of doubt in front of one's children, what would become of them?!

Talking to some of the fourth-grade children I found that they could quite frankly doubt that there is a God or even down right deny his possible existence. But this is something they do not talk about with their parents or let on to in school. It may appear only as forms of jeering, disturbance and impoliteness. Their greater problem is perhaps to understand what adults are up to, trying to cope with them and their constructions of the world, than to really care if there is a God or not, if it is necessary to believe or not.

According to the Pfarrer, about 50-60\% of the parish go to church 
regularly. He may be right, he may exaggerate somewhat; my impression was that he was not far from the mark. He is aware of the division of labor between men and women, as he is of the fact that some Linden people never go to church or maybe just a few times a year at particular holidays such as Easter and Christmas, when there is a funeral or when a son or daughter is to take first communion. We call them Auswahlschristen ('choice Christians'), the Pfarrer says of himself and his colleagues, they pick and choose as in a supermarket, take what they want and leave the rest. To them the church is an offer among other offers, the Pfarrer says, critical of such people's lack of responsibility and their unwillingness to bend to something beyond their own egoistical wishes. He does not abstain from letting people hear of this if he finds the chance. For example, when the chairman of the Sportverein, Herr Tahl, suddenly died, the Pfarrer said at the funeral, that Herr Tahl had not been a very frequent visitor to the church, implying that he actually did not go to church, which everyone of course knew. Yet this is taken as a terrible affront, people are upset that the Pfarrer, at such a moment, takes the liberty to speak badly of a person who is dead, and a person who was both liked and had had 'a position' in Linden. What he implies is that Herr Tahl had not been a good Christian, that he had not been gläubig. The Pfarrer takes the opportunity to aim an innuendo at the Sportverein and kindles the underlying antagonism between the church and the Sportverein. They both strive to dominate the public arena, yet are also to some extent dependent on each other. With this reproach the Pfarrer also turns indirectly on those who keep away from church when all is well and then, when things go wrong and people become ill, or die, take it for granted that the church and he as Pfarrer should be there for them. The church is crammed with people, the Pfarrer has the whole congregation before him and he decides to use the event to give them what they have earned.

The church is essential in terms of power and position. People who have a prominent position in Linden and wish to convert this or use it in the political arena will, unlike Herr Tahl, often attempt to go to church each Sunday. This may also apply to whole families, but it is mainly men who are upholders of prestigious and political positions. In this context, the institution of Frühschoppen, mentioned in chapter 3, is of significance. It is a generally pleasurable form of association for men, an all-male Sunday world linked to the church and the family, but also an important forum to 
make or uphold political and economic contacts.

For most Lindeners, the Eucharist is not without its problems. It is closely but controversially connected with confession, which for people of Linden means that one should have confessed not too long ago to be able to receive the sacrament. But how too long ago is conceived varies. Some people only confess once or twice a year, others five or six times. Few will confess more often than that and there is no longer a demand that one confess before each Eucharist. How often one communicates after a confession is a matter of personal conscience and judgement, something the teenagers seem to think that most adults do not make much use of. Those who communicate at every Mass are bound to provoke gossip about their pretence to purity and holy manners. Many people feel very uncomfortable with confession, saying that it is embarrassing, childish, false, that it is none of the Pfarrer's business what they have done or not done right. ${ }^{2}$

Women and men relate somewhat differently to the church, as do the children. The teenagers do not go to church often enough, many adults will complain. It really depends on how the woman of the family is, if she goes to church, takes her small ones with her and sees to it that the older ones also go, then 'we would see many more young people in church', is a common view. The activities of the man of the house are more seldom alluded to in this context. ${ }^{3}$ This matter of not getting the young to go to church is not seen as something exclusive for Linden, but is thought of more as a nation-wide problem, a problem of the modern world. So, the church must modernize, the Mass must take a hold of questions relevant to people, the young especially. And that which people are expected to believe must be more 'realistic'. The young teacher, Herr Bender, is enthusiastically modern, engaged in church activities, striving for an influential position in this new Heimat of his. Drastically, and in a joking manner, he declares at some point in a meeting that he for one is not much interested in the Virgin Mary, 'she isn't my type', he chuckles. He finds it obsolete to idealize the virginity of Mary. That she has existed is an historical fact, as he says, but not that she has been a virgin mother. $\mathrm{He}$, as others with him, find it high time to make the Bible more historically realistic and so make Christian belief more believable. The Pfarrer is not deaf to this, perhaps a way of not seeing himself become obsolete, at times taking the initiative towards being modern.

But there is a kind of concreteness, as it were, to the realm of belief 
which is not unproblematical to the Pfarrer and those more theologically versed. There is a contrast between, for example, Herr Bender's conceptions and those of Hermann Hirsch (mentioned in chapter 3), yet they are in agreement as to the value of 'facts' and 'realism' and science. But Herr Bender is more prepared to discuss the symbolic value of the Biblical stories and Christian dogma, at the same time concerned with sorting out that which is not scientifically possible in an attempt to make the Bible more authoritative in the modern world. Hermann, on the other hand, shrugs his shoulders with some disdain at that which is not observable 'how can they make you believe in heaven and hell when no one has seen either one?! There have been astronauts way out there and they didn't find anything.' Hell is even more of a problem, for where should it be located? 'And how could Jesus walk on water? Why, it's childish trying to make us believe stuff like that!' Even if Hermann is being extra provocative he does touch on problems people have trouble coming to terms with, the relationship between the symbolic and the concrete, or the 'real'. What are the symbols symbolizing? People will say that they understand that one should see many stories in the Bible, the miracles of Jesus, 'symbolically', but they also seem to feel at a loss as to what they are symbolizing. It is as if the believer in Linden feels up against a non-truth when confronted with the 'symbolical'. This resembles the situation in school and kindergarten where the children are not confronted with any theological debate, so to speak, but with the moral values of Christianity, exemplified through 'realisitic' stories.

The tug of war between the valuations of the free world of inner, personal conviction and the demand to have this socially manifested and controlled is at times painfully felt by many teenagers. In particular, those engaged in the youth organization of the church, a nation-wide organization, called Katholische Jugend Gemeinschaft, articulate a critical stance to the rules which prescribe the 'behavior of belief'. They seem rather to understand belief, being Christian, as exclusively a matter of inner personal conviction, demanding a closer link between belief and action as they see this link. To them this means that one can be a good Christian, a believer, without going to church all the time. That confessing and communicating without 'truly feeling anything' is false and so meaningless. They are critical of their parents, of the falseness of much of adult life, as they see it, and they try to work out something which they consider to be 
their own individual choice of being.

Whether critically, indifferently, or trustingly, people are concerned with being Catholics, Christians. This is then often expressed in terms of belief, but this is not the sole, or perhaps even the main, force lending the church, or 'religion', significance. The belief in belief, the conviction that belief is a necessity to make humans into good persons, orderly social beings, appears to be pre-eminent. The church is the epitome of order, having claims to be the knot which ties all social and ideological strings together, so to speak. It is not possible for people in Linden to really imagine a society without Christianity, without religion, even if each one of them can perhaps personally imagine themselves fairly well off without church and especially Pfarrer.

On the one hand, the person is conceptualized by Lindeners as free and autonomous, each makes his or her own choices as to how life should be lived; on the other hand, the person is only possible to conceive of as part of a social whole. It is primarily through the process of learning what this 'whole' is and what it demands, that the person is formed. The church lands in a precarious position in relation to this contradiction, since it traditionally constituted an encompassing ideological and social force under which the individual will should be subordinated, subsequently occupying a seemingly more humble position in people's consciences, but still with certain claims to be part of the formation of the person.

The church is then not indisputably central in the Lindeners' lives, as has been pointed out, and there is a great worry among those who see the church as a particularly important political and educational instrument that the church will lose its influence over the development of modern social life, so marked by scientific success and notions of individual freedom and development. For Pfarrer Kreis, as for several other Lindeners, it is essential that the church does not lose its position in this changing world and in discussions and conversations such people emphasize the need to modernize the church. Expressions of this struggle to manifest Linden both as a whole, a Gemeinschaft, and as part of modern society, are the various educational meetings and seminars which the church arranges; the engagement of the children and youth in different activities; the reshaping of certain church rituals. In this way the school, the family and the church are brought closer together and for some ambitious Lindeners it means that they can attain political advantages. To participate in the ongoing 
debate, be part of the public discourse is one of the means to influence and power. To arrange, act and speak publicly, to be part of committees, is to become one of a seemingly indispensable kind. Ideas and relations seem to become more 'real' through the organized discourse held about them.

Particularly during Lent Pfarrer Kreis and the church board, sometimes in co-operation with the school, arrange a number of lectures and seminars. The topics range from 'Terrorism and the question of death penalty' to 'Religious upbringing and the problem of sexuality'. The most salient feature of these meetings is the problem of Erziehung. The seminars and lectures are similar in structure to the various meetings held in school and I shall present one such occasion, on the problematics of sexuality, as in school spoken of in terms of Aufklärung ('enlightenment'). The body is held forth as a moral theme for which society, in terms of the school or the church, must take responsibility.

\section{Debating the moral body: a seminar on sexuality}

Pfarrer Kreis opens the evening's lecture, greeting the invited expert, the Realschulleiter ('secondary school leader/teacher') Herr Stein, saying a few initial words about our keen interest in Erziehung and in questions of belief. With the opening of the Lebenkundliches ('life knowledge') seminar series (five sessions) he refers to the Sixth Commandment Du sollst nicht ehebrechen ('Thou shalt not commit adultery'), adding that Herr Stein would be talking about this matter, that is, sex, quite frankly, from a Christian perspective.

The middle-aged, friendly Herr Stein, a teacher in German, History and Erziehung, greets them and is very glad to be there, and glad to see so many young people among them. He uses a familiar tone, joking at times, engaging his older audience to share in his experiences of teenagers. Having five children himself, he says, he knows much about it and he turns to the younger audience with his authoritative understanding of what development implies. He intersperses his talk with quotations from German classical literature, primarily Schiller, ${ }^{4}$ and from scientific reports on the sex life of men and women, and he compares today with yesterday, when he, for example, grew up and didn't know anything, there was no Aufklärung in those days. 
The main theme, then, is that of sexuality and the emotional and social relations which it entails. This necessarily brings up the question of freedom, der freie Mensch ('the free person'), and it is generally agreed that 'no one can do whatever he or she wants', that is, freedom has its limits. The 'good' and the 'bad' sexual life is explored in relation to the emancipation of youth, that is, their development into adulthood. Girls (and women) are compared with boys (and men) as to their habits, traits, and sexuality. The question of friendship and relations of love is ventilated. All these subjects are more or less superficially mentioned, discussed or just alluded to during the several sessions.

Marriage is one of the important social goals in life, and it implies a great deal of responsiblity in the eyes of adult Linden people. Its concern is the establishing of a family, but it is sex and love which initiates it and it is mutual love on which it should rest all through life. The problem is that people marry when they are too young. They do not know anything about love at the age of $18-19$, so they should wait. Such is the opinion of many adults, especially of the parental generation of these young people. Living together in a marriage is not a private matter, not in any society! Herr Stein agrees with them.

It is an acknowledged fact, normal today, even if not really liked by very many, that the young engage in pre-marital sexual relations ('and so they did before, but it's more open and honest today', one woman whispers to me). Actually, though, they should not, for they do not know what they are doing. 'There is so much uncertainty, you don't know how you function, or what love is. If it does not work then it can lead to impotence or frigidity'. There are references to reports about this, and one man reminds the audience of the threat of genital illnesses which flourish when sex becomes irresponsible (this was before the era of AIDS).

The problem is that the body develops faster than reason and the will, Herr Stein says, which sets great demands on parents and really the whole adult world in the form of school, the church, and even the mass media. The uncertainty of parents and of other adults influences youth negatively, making them unsure of themselves in their development. They become a prey to bad influences, like the various religious sects, and unattainable wishes alluded to in magazines and advertisements.

Parents must be happy about their sex, be proud of being man or woman, 'one's sex is the basis of the temperament', as Herr Stein phrases 
it. Although he is proud enough of being a man he also admits to the prudishness of his own generation, one should not belittle this problem. But then, again, this sex-wave which is flooding us is not something to be pleased about - 'sex isn't enough to make you happy. In America they are even starting to talk about sex stress'. But as for him, he has heard more about it in terms of Pflicht ('duty') - eine angenehme Pflicht, nicht wahr, meine Herren? ('a pleasant duty, isn't that so, gentlemen?'). There is some slight squirming and smiling in the audience. BUT, every third male who seeks medical aid has sexual problems, he comes down on them, and refers to research reports. The situation is quite simply troublesome.

Sexuality is troublesome, but in a setting like this, formalized in the sense of being fairly predictable, led by an expert, it is possible to mention sexual acts more directly (part of the discourse of 'scientia sexualis', which Foucault scrutinizes, 1980) than in other situations - where it is either turned into obscene jokes and allusions or hardly mentioned at all. Here reference is made to an array of reports and studies given a scientific status, which inform about sexual behavior in primarily quantitative terms. This lends a kind of personal distance to sexuality which makes it easier to talk about. There is a kind of implicit agreement that one does not openly interpret what is said as having to do with the person talking. This is akin to the relative devaluation which personal (individual) experiences are given when it comes to learning and Erziehung. Such experiences may explode what must be held under control. I would say that the seeming openness of discourse builds on a kind of desexualization of the body, bodily pleasure for its own sake is rejected. It is in a way a disowning of one's body, but a disowning which not everyone willingly accepts. The jokes and laughs which occur off and on penetrate the barriers, working on this conflict.

In his educative manner, Herr Stein brings up the subject of masturbation as part of general comments on the development of the young. This starts off a small discussion he obviously had not anticipated. One of the young boys states, a bit uneasily, that masturbation can ruin relations to the other sex the rest of your life. Well, that was what people thought 'before', Herr Stein says, and according to a book he read on the subject of sexuality as a young man, almost everything led straight to hell, but now we know better. Masturbation may lead to or depend on a low sense of self-esteem and guilt, and there are parents who forbid it. But to mastur- 
bate during puberty is neither sinfull nor harmful. For adults to masturbate, on the other hand, is wrong. It is egoistical and a way to distance oneself from one's partner, according to Herr Stein.

It becomes clear that Herr Stein is only referring to the sexual life of boys and one of the men wonders if only boys masturbate - 'I mean, girls may want to be with the times, too!' Herr Stein is quite perplexed and cannot understand why girls should masturbate. For boys it is part of their development, but for girls? No, he cannot imagine it. One of the women comments, like the man earlier, that 'these are new times, the girls want to have their rights now, too'. Petra, a girl of sixteen, refers to an article in Der Spiegel she has read according to which most youth masturbate and $54 \%$ of the girls. The chairman of a local Catholic Workers' Organization has also read about a study of masturbation, about women. In this study it is shown that women's capacity of getting satisfaction from sexual intercourse is quite low, $50 \%$ of women never have an orgasm. Herr Bender considers that the thing is that girls do not talk about it, they are ashamed. 'But how on earth would a girl get such an idea?!' Herr Stein wonders, taken aback. Herr Haupt, whose youngest child is a girl of three, something he does not mention, tells him that little girls examine their own bodies as much as boys do, even very small children do that.

For a while the tables are turned, Herr Stein for all his reading and his five children, has missed something these people seem to know a lot more about and which they seem to acknowledge. He has no help from the Herr Pfarrer who does not say a word or show any kind of emotion. The whole subject is difficult to handle, it only works on the abstract level and here suddenly a breach, however small, has been made. Do these girls masturbate? Have these women been masturbating as young girls? Herr Stein's wife too, and his daughters? Does everyone masturbate? The Herr Pfarrer? And who is, after all, expert here? It is obvious that discussion has come to an end, it is getting too difficult for everyone to keep face, none of the women except Petra offer any comments, and there are no jokes to be had this time.

There is a considerable interest in and preoccupation with the body. From the very beginning of life the body is controlled and manipulated by others to make it grow and develop, to make it conform to an idea about the body. The body has certain needs which are part of its nature and these needs must be satisfied, or eliminated, under control. At the meeting 
the breach between Herr Stein and his Linden audience comes when there is a claim that the body is, and always has been, an erotic body. I think it takes a certain amount of courage to make this explicit. But there is no slight degree of ambivalence which is embedded here. This can perhaps be noticed primarily in relations to infants and the problem of dependency between mother and child, but also to the dialectic between Ordnung and the burlesque streak life has in Linden.

At the meeting, talk about sexuality generally, and masturbation specifically, is mostly held in a matter-of-fact key, and then, after a while, a breach emerges over the conceptualization of the body - over this very sexuality. For as they are talking about the developing young person they are talking, in a sense, about nature, the necessity of nature, as I see it. The boy seems to represent this nature, they are this nature, that is, it is natural for a boy to masturbate. The very nature of his body makes this imperative - he overflows with semen and this is, and must be, let out. As the bowels must be emptied when they are full. This can be defined as not sexuality, not aimless pleasure, and therefore be made admissable. It is natural nature, not 'unnatural nature'. It is within the bounds of society. When it becomes clear that girls also masturbate it is also made clear that masturbation is a sexual act. There is no 'natural necessity' for girls to masturbate. It is a 'meaningless' act for it is only directed at satisfying desire, its aim is bodily pleasure, not to regulate a system, establish a balance which nature demands. It does not produce anything. Some of the audience want to recognize the sexuality of the act, that the body is sexual, which Herr Stein wishes to deny. All talk about sexuality must be drained from its sensual, erotic charge and instead be made (publicly) admissable through a scientific language. This applies to all sexuality, but particularly to that of children, and women.

As long as the bodily activities are a part of the unavoidable nature they can be accepted and talked about in such terms, however unpleasant it may feel - toilet training, for example - although I have my doubts as to the unpleasantness actually felt. There is an apparent interest in bowel activities, bowel disorders preoccupy many of the women and they use laxatives quite extensively. A baby sucks its nourishment, but to just suck for the pleasure of it, which a pacifier implies to the Linden mothers, can make it into something almost revolting, so a child may be discouraged to use the pacifier as soon as possible. But a feeding bottle makes the sucking 
activity meaningful and so can be kept up for many years. The sweet tea or Saft in the bottle is controlled by the mother or Oma, they fill pleasure with 'meaning' as if attempting to hide its 'meaningless' nature, and the bottle is quite obviously useless when empty, which the breast never is.

When control is slackened, when the Erziehung is not upheld, then the body becomes unnatural, as it were, a place of egoistical desire and so asocial. To be naturally naked at home, letting one's body be seen by members of the family or in the gym dressing room, to give details of sexuality in terms of Aufklärung in school or at a seminar like this one is all within the bounds of the modern scientific body which also can imply a recognition of submissiveness, of an hierarchical order. Obscenity and the wild places are a subversive comment on this order, obscenity, along with rudeness as a kind of radical possibility. Since the body as a means of pleasure and suffering is an incontestable part of everyone's experience it may become a very potent joke. It is made into the stage on which the absurdities of life are revealed and few are left unmoved.

The body is then a potent arena in which the endeavors of upbringing and education are performed. The body is manipulated in various ways to make it conform to the ideals of the real, good person. This is an underlying theme of all Linden educational institutions, the church, not least. Bodily order is like an image of individual and societal order, and the church strives to be the mediating agent between the two.

\section{Gemeinschaft and conformity among youth}

At seminars and meetings like the session with Herr Stein there are some teenagers who participate, but it is still the adults who dominate. The recurring claim of the church that it must engage youth is manifested in other ways, primarily through the Catholic Youth Gemeinschaft, the KJG, which I mentioned earlier. The Catholic Youth in Linden has not been active for more than a few years and it is not a big organization It may not be one of Pfarrer Kreis' initiatives but together with members of the local unit of the Katholische Arbeitnehmer-Bewegung, the $K A B$ (the Catholic Workers' Movement), he supports and dominates this group, resenting loss of control. ${ }^{5}$

When some of the teenagers go off to the Catholic Youth 'tea hour' (where more coca cola is consumed than tea) others will take their Mofa 
(motorcycle) or walk over to the Wirtschaft or the café on the corner and meet with the group of teenagers who call themselves the Black Angels, the BA for short.

The Catholic Youth and the Black Angels are then two youth groups in Linden. The BA has not existed for very long, as may be common for such loose, age-specific groups. They tend to come and go. Far from all teenagers are members of these groups but they may still participate in some of their activities or meet with some of them on various occasions. The groups represent certain contrasting possibilities for youth, but the boundaries between them are also blurred, some are members in both groups. They tend to consider each other, as groups, as quite different, and so do the adults, but they have several common interests. They enter the same social world but from different vantage points. There is a degree of antagonism between the groups so as to uphold difference even if some of the youngsters have connections with both. It is part of Catholic Youth ideology to try to overcome the differences, wanting to recruit more members. Adults will encourage this, whereas no one admonishes the BA to start recruiting members. The BA verge on the 'disorderly society', the KJG on the 'orderly society', but both have features which draw them to a common Ordnung.

Most of the BA do go to church, they say that their parents demand it. One of them was even Ministrant ('choir boy') until recently. When you are younger you want to be Ministrant, but then when you are about 1516 you have grown out of it, they say. Those few who do continue are thought of as childish. But even if they go to church this does not make them inclined towards the Catholic Youth. There the Pfarrer is the one who decides everything, and they don't like that. They don't want to sit there and sip tea and discuss. It is true that the Catholic Youth has accepted adults into their midst in a way which the BA would not accept, but the Catholic Youth also associate on their own and the BA meet and associate to some extent controlled by their parents.

All, or most, youth activities have some connections with and sanctions from the adults. The associations are in this respect important. The main ones, such as the Musikverein, the Sportverein, and somewhat differently, the Freiwillige Feuerwehr ('the voluntary fire corp'), have their youth groups, of which there are more for boys than for girls. These associations do not engage all youngsters in Linden, as they do not interest all adults. 
But since activities arranged by these different associations, as by the church - meetings, excursions, feasts, ceremonies - attract so many participants and spectators they are made known to almost everyone.

About twenty-five youngsters, more boys than girls, in their middle and upper teens are members of the BA. Many of them have been hanging around together quite a lot before without being 'a group', which one of the older boys inspired them to become some years earlier. Having a name gives them a sense of Gemeinschaft, they say. They are also influenced by the other groups in the area - the Veni, vidi, vici from Brücken, the Devil Drivers from Altheim, for example. There has been an increase of these kinds of youth 'gangs' in the region, but they do not see themselves as Rockers, Rockers fight with chains and use stilettos, they point out, usually they are also older than these Linden youngsters. But of course there are fights between the gangs sometimes. They drink pretty much when they are out, perhaps not on ordinary weekdays, but when they are off to a dance, or some tent-feast which are so common in the whole region, and sometimes some of the boys get into a fight with members of another gang.

No great spectacle is made about the Black Angels in Linden. They meet regularly at the café on Mondays when it otherwise is closed. Uwe, the only son of the owners, is a member. They will go to one of the other pubs quite often, go off to Hesse in cars and motorcycles, but most of the younger girls must be home by nine o'clock in the evenings so they are not able to always participate in the different excursions. They complain about this, finding their parents too strict. Generally, this is the main weapon parents use against their unruly teenagers, not allowing them to be out. Regular house arrest is something they all have experienced more than once. This is their main complaint about lack of freedom - not to be able to stay out as long as they want. But then again, kids shouldn't have too much freedom, one of the young boys thinks. Children have too much freedom, they should not be allowed to do what they want, smoke and drink without constraint. He drank pretty much himself, but did not smoke.

These youngsters are either in school, the Berufsschule, or have a year or so to do in the Hauptschule - both schools of lower standing, but then also the most common. The older ones work. A few of the girls work in the local leatherware firms, one boy is employed at the local gas station. Some have parents who own small firms where the children help out, and will perhaps take over. In the many smaller and larger industries in the 
region they will find or have found employment. Their idea is to stay on in Linden or nearby, marry early, probably because 'you have to', that is, the girl is pregnant. No harm in that, it seems to them. Now they are out for some fun and excitement, a haven, after all, from parents and the adult world, a world they are very much a part of.

The Catholic Youth are more what can be called middle class youngsters, mainly, most of them go to higher secondary schools, Realschule or Gymnasium. The Black Angels' program is completely non-educative, which is an important aspect of the critique against them, 'they have no goals'. Sometimes discussions within the Catholic Youth arise as to how to get the Hauptschüler to participate, take an interest in their activities, but they assume that their 'talk is too high'. That may be, but it is also probable that they represent a compliance with Linden adulthood to an extent which makes other teenagers, at least, see them as non-sensual and submissive.

These youth groups raise the question of class. It is not the only context where class differences arise as a point of reference for the Linden people, of course, but it is an important one. The KAB are preoccupied with this question, which as they see it concerns the church, the family and education - relationships and institutions which appear vital to them, and to most Linden people. It is education which is used as a main conception of class. It has potentialities which, even if not actually realized, somehow override those of income, however important this is.

The Catholic Youth is preoccupied with actively participating in the forming of the child, they engage themselves in this educative endeavor. This makes them more prominent in my description, even though I do consider youth groups such as the Black Angels both interesting and significant. The Catholic Youth are critical of the adults, they wish for a more genuine attitude towards life, and they use some of the Christian idiom in deploring their lack of dedication. The Black Angels, on the other hand, do not intellectualize and do not consider themselves to be so very different from the adults they avoid.

I shall take the event of Christmas to describe and consider some of these aspects of the Catholic Youth, the educative project they are engaged in, which also underlines the encompassing ambitions of the church. Christmas is not a spectacular feast in Linden and it may seem out of place to concentrate so much description on this event, but its emphasis is very much on the family as part of a Gemeinschaft, with the children in focus. 


\section{Dealing with modernity}

It is since the arrival of Pfarrer Kreis that the Catholic Youth has seemed to blossom. About every two weeks the 10-15 boys and girls meet in the room they have at their disposal in the town hall, their so-called Teestunde ('tea hour') and discuss their participation in church events, or have debates about specific topics, often connected with social, ecclesiastical, and to a lesser degree political issues. Sometimes the Pfarrer will participate at the sessions. If he is there too often they feel he dominates too much, if he is there too seldom they feel he does not care enough about their activities and opinions.

Some weeks before Christmas, when they are going to plan the Christmas Mass and their own participation in it, the Pfarrer does attend their Teestunde. This time he even surprises them with his modern views, although not his manner of stating them, to be sure. He maintains a fairly authoritarian style towards these teenagers. $\mathrm{He}$ is not directly unfriendly, but without much ado he dismisses all that he considers irrelevant of what they say and suggest. He is not called on to motivate his actions, but neither do the youngsters accept everything he suggests.

He declares on this occasion that it is high time to change the Christmas Mass, especially the crib. It shouldn't always look the same year after year, always this cozy wooden crib. People just take it for granted and have long since stopped reflecting over its meaning. He wants to shock them, he says, shake them up a bit. He tells them to use some modern material when making the crib, like plastic. The youngsters are generally keen on his suggestion. Actually they have been thinking along the same line, wanting to relate the birth of Jesus to relations of today, make people 'react'. But plastic, no, not plastic! Maybe a concrete building, but the Pfarrer goes too far. They are more conservative than the Herr Pfarrer, as one of the girls expresses it. And they are not nearly as well prepared. He enters with his arms full of books describing how Christmas may be celebrated. 'But one thing, we must keep the ox and the mule in the crib, that's ein Stück Heimat to people', Pfarrer Kreis says.

From one of the books he reads aloud the Christmas tale, the part about Joseph and Mary looking for a room, somewhere to stay, all the time being rejected. The text has an everyday tone and style and he reads it with a certain harshness. One of the boys comments on its crudeness. 'Yes, but don't you see, it's supposed to shake people up!' Pfarrer Kreis 
is eager and determined to have his way. He wants to wake people up, make them see the Bible, the life of Jesus as part of the contemporary world. People should not take everything for granted.

The conservatism and the modernity which is spoken of is not a question of political (party) adherence, which may seem obvious. The modernity Pfarrer Kreis appeals to, and which is seen by many as a necessary and positive development of church rituals, 'otherwise people, especially the young, will forsake the church', is rather about a mobilization of fundamental orders of society, of calling the herd of individuals back into line. The problem for these youngsters is that he is taking the critical initiative away from them. The Pfarrer is a 'key modernizer', using the youngsters and the children as pathways to reproduce the order of family life and the order of society in which the family is considered fundamental. Adults may grumble about 'all these children disturbing Mass', but the Pfarrer, and his closer adherents are relentless.

The youth group spends many evenings discussing and finally making a crib for the church, to be placed to the side of the altar. Together with this they have decided, prompted by their chairman Robert, to make a Wunschbaum ('wishing tree') instead of the ordinary Christmas tree. In place of candles and other decorations it has little notes hanging from the branches. The notes have wishes written on them and these are meant for people to read and contemplate the meaning of Christmas, how they live their lives. One girl calls out, 'Why notes and wishes? What good will that do? What does it have to do with the crib?' Robert takes some pains to explain it to her: 'We must make people react, think, reflect, not take everything for granted'. She still thinks it odd and makes a bit of a show of her scepticism - Nachdenken und nachdenken! ('contemplate and contemplate!'). 'What if I wish that I shan't have any enemies, what good would that do?! Everyone has enemies! It won't change anything.' And Robert has to agree, but both he and Lovise, who is as active as Robert but much less domineering and more good-natured, argue that it would still make people think, reflect about what it means.

And so, through a chorus of mutterings, protests, teasing and jokes they all start talking about what to write on the notes, what wishes to make. 'I wish for a Mofa (small motorcycle)', Maria calls out. Robert does not accept that, 'it's got to be more geistlich ('spiritual'), a motorcycle is 
nothing to wish for!' This leads to a prolonged and lively discussion about whether one can wish for material things or just geistige Dinge, was vom Herz kommt ('spiritual things, that come from the heart'), as Lovise puts it. But Maria is persistent, 'people wish for THINGS, material things, that's often the most important to them, and we should write what people themselves care about, too'. But Robert is uncompromising and Maria finally gives in a little bit - 'ok, people don't only care about things, but it's one of their wishes'. And Lovise joins in wondering if he, Robert, never wants material things. They all agree that you cannot deny that 'things' are important. But in the end they accept Robert's line of thought, that the wishes should be of a 'spiritual' kind. Maria is annoyed for a while and a bit hurt, feeling that Robert seems to imply that she is not good enough - 'what do you mean anyway, that I should be gläubiger (better, more of, a believer) or what ?!' She does not receive a reply to this and general, loud talk takes over.

Ok, what should we write? Lovise calls out. Suggestions start coming. 'That people in Linden do not gossip so much'. That is good, they all agree, harsh but good, and really important. They continue: that one care about and understand the old and the young; that one is satisfied with the Christmas gifts one receives; that people consider how they really celebrate Christmas; that there should not be so many quarrels and fights in the families at Christmas. 'We young people are really the ones who can change things. For example, if you read the Christmas tale you can talk about it, say what you think. That would really be good'. Lovise is optimistic but another girl does not think that her parents would like it if she has views that differ from theirs. The others agree, there's no room for discussion at home. Some of them look dismal at this comment.

When Christmas finally arrives, the Pfarrer has also spent time with a group of younger children, ten to twelve years old, practicing some sketches they are to perform at the Mass on Christmas Eve.

The church is crammed with people, parents and children, Omas and Opas. One can hear the shrill voices of the smallest children. A huge Christmas tree has been erected behind the altar. Lights are low, candles are burning. This is a Mass where the children have been placed in the center. The school children perform their sketches and the Pfarrer moves about like a theater director. The children also play clarinet and flute in 
small groups, a few are called to say prayers and the whole congregation sings Silent Night and other Christmas carols. Almost everyone communicates, row upon row of people stand up front by the altar. The Pfarrer has his two lay helpers distribute the holy wafer. One can see the youth group's crib to the right of the altar, the 'wish tree' wavering to the side of it with its small white paper notes with wishes. The empty notes are meant to be used for the wishes from the congregation.

A first sketch performed by the children is a story about the Christmas tree. It is difficult for anyone to see or hear what the children do and say since they act with embarrassed hesitation, having difficulty to speak up. The Pfarrer speaks about the meaning of the performance and through him one can understand what was going on. Two children play Adam and Eve in paradise (dressed in everyday clothes), chopping down the apple tree as they have been lured to do by the Devil - and so today we decorate a Christmas tree and give each other gifts as a thanksgiving to God, Pfarrer Kreis tells us, the Christmas tree symbolizes life and its reconstitution.

The other sketch picks up a theme which is very common in religion class in school, and in kindergarten. It is about a group of children who are playing games with each other. They start quarreling, they disagree about something and after a while they run away and leave one child standing all alone. After the small performance Pfarrer Kreis says that this is meant to tell us, mainly the children, that one should be helpful and considerate of one another, that it is unkind to leave someone out.

Pfarrer Kreis has been standing near them during the performances holding the microfone towards them, whispering lost words and lines to them as they struggle with their movements and their somewhat strained Hochdeutsch ('High German').

Some people appreciate the children's performances and that Pfarrer Kreis engages himself for this. But critical voices are also raised. The Pfarrer goes too far, some think. Some notes which hang on the 'wish tree' express dissatisfaction with this 'new mode' of engaging children in the formation of the Mass. It is a disturbance and the Holy Mass loses all its dignity, Christmas should not be so everyday-like. Children are not generally considered solemn enough to carry the burden of formulating what for adults and society is vital. They are, after all, not yet 'real persons'. It is as if life were being devalued into a game, child's play. It is good and well that children participate as audience or play a small and regulated role, 
such as being choir-boy (or choir-girl), or are sometimes called on to say prayers, play an instrument, and the like. It is also in order that they are taught good behavior and moral standards. But boundaries are blurred when children are given the main position in a ritual. This conflict of boundaries is also provoked by the simplicity of the whole performance why go to Church if it's no different from the rest of everyday life?

It is not only in relation to children and the family that modern society is hailed by the church; other events may be reformulated in this vein. The Harvest feast in October is one such event. This feast marks the particularities of Linden and people's work with the land, what is left of it. As it developed during my stay it seemed to demonstrate how the church strives to be an influential part of a social world where it no longer has the encompassing position it used to have.

As is usual at the Harvest service, the front area of the altar is decorated with large baskets full of beautifully arranged fruits and vegetables, grand loafs of bread from the bakery, bottles of the rich local wine, and vases with tall sun-flowers placed along the sides. All this are donations from the small local firms and from the more ambitious gardeners and farmers. The whole parish is a pride to itself - through hard work, talent and good fortune, all within the bounds of the church.

This year the service is extended to include not only the fruits of labor with the land but also the fruits of our modern technology and lifestyle, the dangers and joys this entails, in the form of cars and the problems of traffic. A police officer from a nearby town has been invited to deliver a kind of layman sermon about traffic and its dangers, the many accidents which must be avoided. The Pfarrer also speaks about the dangers of car-driving, that young men are particularly vulnerable since they are prone to drive too fast. But there is also an air of admiration for the car, the freedom of movement it bestows on us, and its practical value. Toward the end of the service a young man comes forward to say prayers. $\mathrm{He}$ wears a nice suit and a great big red and white motor-cycle helmet. $\mathrm{He}$ prays that God will protect him and his friends when they are out riding their motorcycles. Amen, he bows and the congregation answers Amen. Finally the brass band plays to the psalms, filling the church to the ceiling with its very impressive music. 


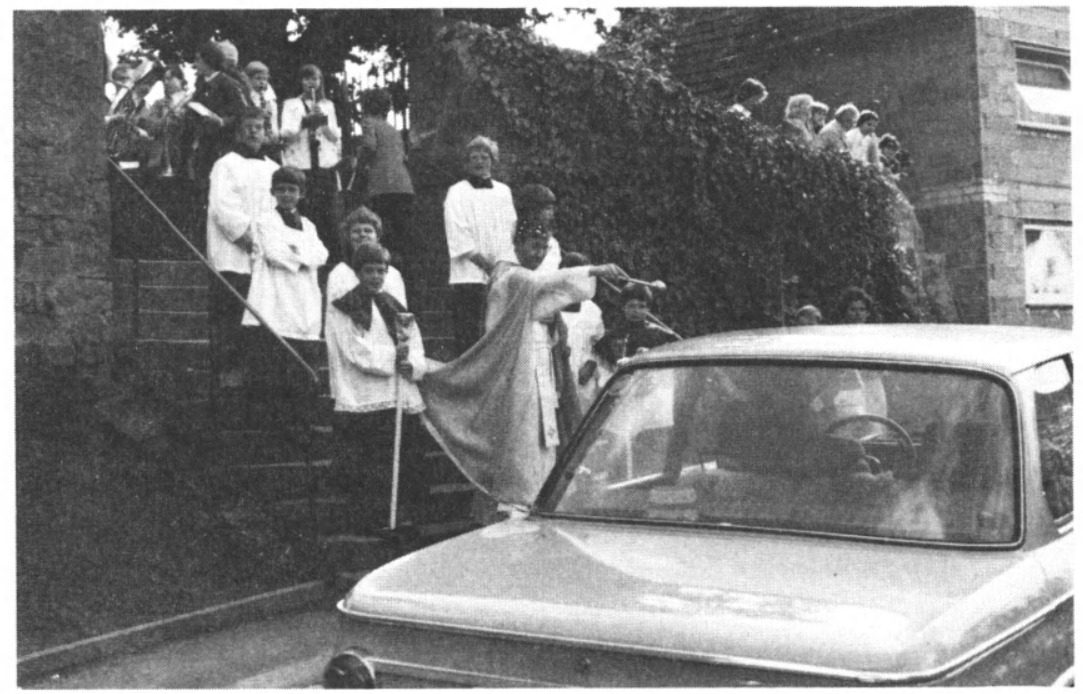

The Harvest Feast. After Mass the Pfarrer blesses all cars.

After Mass people leave the church. The Herr Pfarrer Kreis then comes outside and goes down the steps leading from the church yard to the street below. There he stops and stands surrounded by his young choirboys. He is dressed in a festive mantel in white and gold. The brass band, its members in their white shirts and light blue vests, the Bavarian colors, prepare to continue playing where they have reassembled near the top of the stairs. There are people leaning over the wall looking down to where the Pfarrer is standing, and people stand on the sidewalk watching.

With one of the choir-boys holding the incense-burner, the Pfarrer himself prepares to sprinkle the holy water, blessing the cars which soon start passing in front of him on the street. The procession of shining cars is long and each driver looks solemnly ahead as the Pfarrer smiles benevolently and sprinkles. The streets around the church become almost jammed with people and cars and there are a few visiting policemen out directing the traffic so as to avoid congestion. When every car has been blessed the Pfarrer proceeds with his following down to the field where tractors and trucks from Linden and the parish villages have been lined up, row upon row, as shining and well-repaired as the cars. And the Pfarrer blesses each one of them. 
Up by the town hall, next to the church, some of the teen-agers are selling bread, sausages and coca cola to those who have become hungry. It is getting almost too cold and no one stays very long, some of the men are also impatient to get to their Frühschoppen. As for the women, they will soon want to be off to do the cooking for the more extravagent Sunday dinner.

This year the Harvest ritual has been extended and elaborated. The Pfarrer and his closest adherents in Linden are intent on making the church a part of the 'modern world of today' and Pfarrer Kreis wants to think of himself as an essential part of this process. The church brings in 'society' and itself steps out into 'society' and blesses part of its materialization, the car. This way the church takes upon itself to demonstrate that everything combines, is part of the same order, so to turn one's back on the church is to turn one's back on society.

In a sense, I take this to also be a message underlying these other seemingly disparate events, the seminar on sexuality, the youth activities, and the Christmas ritual. The church makes claims on controlling the formation both of the good person and the good society. The youth are in a somewhat in-between position, where choice of action may seem to be greater than for children and adults; but as I see it, they still move within the spheres of Linden arguments of order and disorder.

\section{Learning to be a Christian}

The Pfarrer sits in his Wochenendhäuschen ('week-end cottage'), as priests among themselves jokingly call the confessional, and receives the confessants, one after the other, as they sit in the benches waiting for their turn. It is not always a pleasant atmosphere, as a few of the teenage girls comment. 'People try to push ahead of others, everyone wants to get it over with as soon as possible'. After the few minutes of confession, people will kneel in their benches saying the prayers which are the 'fine' they get for the sins committed, making this part of the confession public.

School children are summoned to confession about four to six times a year. They are called class-wise and this is announced in the weekly church bulletin, the Pfarr Echo. Pfarrer Kreis also checks up on them so that all attend at their appointed time. And parents, even if they themselves do not go to confession and may speak derogatorily about it to other 
adults, will see to it that their children go when called. Children are the family's face outwards, the representatives of the different institutions will judge them through the behavior of their children, so the young ones are not so easily let off the hook. The child must bridge gaps in the social and ideological construction. Religion ist eine Erziehungssache ('religion is a matter of upbringing') as many adults say, it is a matter of learning, as so much of the essentials which make a person.

This Christian learning process has its particular climax with the First Communion, Erstkommunion, and being a Kommunionkind ('communion child') is to be imbued with instructions and apprehensions and festivities. For about half a year the children in the fourth grade are prepared for the completion of their entry into the Gemeinschaft Gottes ('God's community'). The solemn and festive ceremony takes place on Weisser Sonntag, the Sunday after Easter, the most wonderful day of a child's life, as the local newspaper expressed it at the time. But the event is not without its critics, not as such but the way it is exaggerated or modernized. Either it is scorned as having become a regular dress show or it is seen as losing all of its earlier solemnity and dignity.

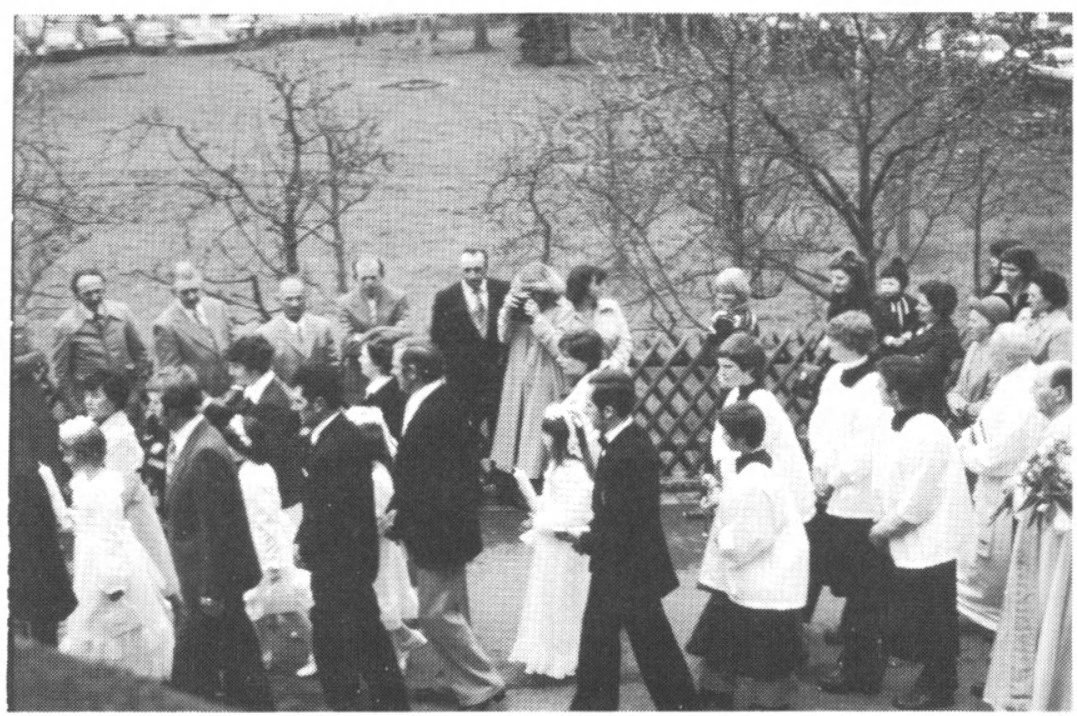

A procession of First Communion-children on Weisser Sonntag. 
The Catholic Church obviously confronts certain problems over this central event of the individual's Christian life. For the church it means, according to one priest quoted in the local newspaper (Main Echo, 28/3 1978), das christliche Defizit der Familien aufzufangen ('to intercept the Christian deficiency of the families'). During the 70 s it was an increasing concern for the church to make the whole event 'child oriented', to underline the sense of togetherness (Gemeinschaft) within the group of children and in their relation to God and the Church, a togetherness which 'does not necessarily only build on the family'. It can be constructed through the tutoring of a small group of children by a 'teacher', a Gruppenmutter ('group mother' or communion mother), who will meet regularly with the children and thus in a more easygoing atmosphere, through questions and answers, small games, drawing and basteln, learn about religion and the meaning of the Holy Communion. The Gruppenmutter is in turn under the supervision of the priest.

The already somewhat prestigious social position is underlined by this new task, which is commented on by others with open or more covert critique. The women chosen to be communion mothers are not altogether confident in their new position, they are well aware of their vulnerability, expressing worry over being knowledgeable enough to teach other families' children, if they really have their trust. They feel it is a great responsibility, somehow they are aggravating boundaries which otherwise should be left untouched. Considering the general preoccupation with blame it is not difficult to sense their worry. Is it really right of the Pfarrer? Some people do find it difficult to tolerate that lay persons are given such a prominent place in the transferring of Christian dogma and belief to their children. And it is not only that they are lay persons but also that they are or have pretensions to be a little better than others, their new task enhances their social prestige, but may also endanger them.

The Pfarrer supervises the whole endeavor quite closely, meeting the mothers regularly in his exclusive living-room for discussion, or rather instruction, which at times makes them feel too controlled and also provokes them into a discrete show of arms about which of them is the better communion mother.

Irmgard Weiss, who works half-day as office clerk in the Lewa firm, is a communion mother and mother of one of the girls in her group of four children. It is this little group which I followed during the ten sessions they 
met, once every two weeks. They sit around a table in the combined study and music room; Herr Weiss is choir leader in Waldhof and has the piano standing there. Irmgard fetches chairs for them from her parents' combined kitchen, dining room and mini-pub.

She has her notes and instructions from the Pfarrer and follows them as closely as possible, but tries to adjust to the children and their own questions and their answers to the given questions. She does not dare do anything completely on her own, she says, it is the Pfarrer who decides. After each session she types down a summary of all that they have been doing, gives it the next time to the children and they are asked to draw a picture which suits the theme. They have a plastic folder and each piece of work is documented and put into it. She does this, she says, to avoid being the target of evil gossip about 'these incapable communion mothers' which she heard the year before. The children come home and say they have drawn pictures, eaten cookies (the group arranges a small feast to teach them about the higher meaning of feasts, leading them up to the feast of the Holy Communion) and the parents will think they just play around and do not learn anything. She intends to show all the parents that the children do learn and do not just enjoy themselves.

Each session has some theme which has to do with the life of Jesus, his death, his resurrection, the belief in him. Stories from the Bible are used, the Emmaus tale, the tale about Zachaeus (see Luke, Ch.19 and Ch.24, respectively) - both recur quite often when teaching religion to children. They also talk about how the Mass is structured, what the different parts of it are called, what the communion is about.

For one session they have been told to take with them a few pictures of people 'whom others disdain'. Which people are they? 'Negroes, prisoners, a child who only has one leg', are their answers. The pictures they have found show prisoners, there is one from the Holocaust, another of a black person in South Africa. Irmgard uses her notes and says half-reading that such people do not get much help from hearing that God loves you just as much as everyone else. What do they want, expect? she asks them. Liebe ('love'), says Anton. Hilfe (help), they say more or less in unison. And also in Jesus' times there were people whom everyone disliked, for example, the sick. In those days they believed that people were sick because they had sinned. The word Sündenbock ('scapegoat') comes from Israel, the Pfarrer had earlier told the children, which they remember now. 
The four children seem to enjoy the sessions. They are also very well behaved, talk and answer questions according to the rhythm of Irmgard's presentation, which is free of the sarcasm and irony they are confronted with in school, even though she may tease and laugh at them, in this way sometimes being a bit ironical. The atmosphere is pleasant and friendly, sometimes so that Irmgard is afraid it is not serious enough, that the children will not be learning, even though it is clear that the children are well aware of the seriousness of the whole matter. It is as if she cannot quite believe that learning can be fun.

The children meet with the Pfarrer in church four or five times some weeks before Weisser Sonntag, without their communion mothers. This is meant to be an inner preparation, the Pfarrer says to them, to make them 'feel with Jesus'. It is also to train them for the feierliche Kommunion ('festive communion') on Weisser Sonntag. Pfarrer Kreis gives them instructions, has them practice how to walk up the aisle towards the altar, where to look during different sequences of the ritual, how to pray, how to hold their hands when walking, how to kneel and when. But, as said, it is also meant to have them realize their closeness to Jesus, the goodness of belief and trust in Him. For this purpose he uses a small book from a Protestant publisher, Jesu kleine Getreue. This is in line with the eucumenical trend which the Pfarrer feels is part of the church of today.

The book has short stories about Angela, Hannele, Claudia, Markus and other children who are firm in their belief and trust in Jesus against all odds. Several of the stories are about children in Eastern Europe who are suppressed because of their belief, but who resist with strength and calmness and manage to tongue-tie their teachers who angrily try to reform them into believing in the State. The only true Gemeinschaft is that with the church. The only true person is the one who is part of this $G e$ meinschaft. There is an overall order one must submit to, but when this order is thought to crush individual freedom and proclaim collective 'sameness' then the individual is free to step forward and protest. And the good protest or revolt is always dignified and subsumed under a higher order, for ideologically there is no total individual freedom. It is clear that it is not the state of the West which can lead to such a protest, only the socialist state.

The children sit together in front of the altar of the Holy Mother, to the left of the main altar. Pfarrer Kreis stands in front of them in his over- 
coat. It is cold in the church, and the Pfarrer is said to be too stingy to heat the church if it is not Mass. The two boys who are the last to kneel in front of the altar go back to their seats and start to giggle and laugh. They cannot control themselves and Pfarrer Kreis turns pale with anger. $\mathrm{He}$ goes up to them, asks them in a strained voice what is going on. A boy next to them tells him something about what has happened. The two are sent out for five minutes to stand in the vestibule but are heard still laughing. 'Now they are going too far!!' and Pfarrer Kreis rushes down the aisle to where they are standing behind the glass doors and boxes their ears so you can hear the slap echo through the almost empty church. The boys are sent to their seats where they sit looking down. Pfarrer Kreis goes up front again, still pale, he too looking down, clenching the bench. It takes quite a while before he begins to talk.

Pfarrer Kreis then picks up the book and talks to them about the girl Angela in her school class. He asks the children, 'If, for example, your Oma was dead, would she hear you if you called her?' Arms wave, but there is hardly any moaning and groaning heard as in school. No! is one answer. Well, do you think Jesus hears you if you call? No, says Bert who had been slapped earlier. This is no answer and the Pfarrer ignores it and asks again. Yes, of course, he tells them, and this is what Angela in the story so strongly believes, and there were many Gläubige in Angela's class. They are all very brave, calling to Jesus for help and they even make the teacher, who is weak in her belief, see the light. She has told the children that $\mathrm{He}$ could not come for $\mathrm{He}$ is dead. But Jesus lives since he was resurrected! The courage of these children, where does it come from? From Jesus, he answers himself. Jesus loves all children. He really loves you, even when you ein bisschen Unsinn macht ('are a bit naughty') and the Pfarrer looks at the two boys and smiles as a signal of truce.

They are asked to say what they particularly like about the story, what they feel is in some way special for them personally. And their answers are of the kind, 'that Jesus comes; that the children always pray; that one should pray to Jesus; that one should go to church not just on Sundays; that one should sing in church'. The answers satisfy him and now they shall all kneel and each say a small prayer aloud. 'Jesus give them the courage to pray', prays Pfarrer Kreis, kneeling behind them. A little girl up front finally starts off: Dear God, I thank you, I thank you for this day, for the food I receive; and so it goes on. They sing, stand up and pray the Angelus 
in unison and then one at a time are to go out, bowing towards the altar when standing in the aisle. Two boys fool around while praying and the Pfarrer becomes silent, goes over to them and asks them what they mean by sacrileging Jesus! There is no answer and they have to stay behind after the others have left. In the scramble out one boy nervously bows in the wrong direction.

Another day, Pfarrer Kreis is in a better mood. 'Today you have been much more orderly', he praises them when they sit down in their benches. He refers once again to the theme of great trust, great courage and reads from the little book about another example of how Jesus gives courage. Little Hannele whose love for Jesus is greater than her fear. She stutters but still asks the teachers to be able to talk before the whole school in the assembly hall. She wants to talk about Jesus, and when she stands there her stutter disappears. What do you think Hannele answers when the teachers ask her how she has managed not to stutter, and not show any fear? the Pfarrer asks them and one boy offers the answer 'I don't know', which the Pfarrer chooses to ignore, looking slightly sore. One of the girls says that Hannele's belief in God is greater. Yes, but say Jesus rather than God, he corrects her, it is more about her trust in Jesus than about her belief. What makes Jesus help some children and not others? he asks them. Bert answers that one child is good, the other isn't. Not everyone believes, is one girl's opinion. With a little irritation he reminds them that he has just said it is about trust in Jesus, rather than belief. No one makes distinctions like that, it is a break with ordinary speech as far as the Linden people are concerned. No one speaks of trust, it is always a question of belief, if one is a good enough believer. In school the teachers do not go into such intricacies either. Together with Jesus one can overcome much fear and anxiety, the Pfarrer concludes and smiles at them. Now, close your eyes and think about Hannele, her fear and her helper, Jesus. Then we think about our own fear and about Jesus. 'Jesus come, make me strong', we say. Think of the prayers when you feel afraid. 'Fear not', says Jesus. There, open your eyes again.

The children must learn the different sequences of the ritual on Weisser Sonntag. He gives them a small stenciled pamphlet with the order of the songs and prayers. The holiest part is the Eucharist, this transcendence of boundaries, when cleansed, the individual is fused with Jesus. The children are to initiate this part by bringing forth their sacrificial gifts 
to the Pfarrer, money for children in other parts of the world. After songs, prayers of thanks and declarations of reverence and belief in the sacrifice of Jesus and his resurrection, the children once more come forward to receive the sacrament together with their parents. After that the whole congregation communicates.

During the various twists and turns of the rehearsal, Pfarrer Kreis is angered a number of times. Some of the children look solemn and behave correctly the whole time, but others disturb and make faces as soon as they see a chance. Some get their hair tugged, and one boy is taken behind the altar as they all stand in front of it, kneeling. They can see how the Pfarrer shakes him and hear him slap his face. He is made to stay there for quite a while afterwards while the others practice the peace greeting, Shalom they are to say and take each others hands. Shalom is a Jewish word of greeting in Israel, he tells them. It is a wonderful word, it means peace. Shortly thereafter, when they have returned to their seats they are to kneel in their benches before communion, hold their hands over their faces and really be with Jesus, and thank Him.

As a final confirmation of the new order a form of pre-Mass is held, not in church but in the small town hall, a kind of intimate and potent rehearsal for the 'festive communion' to be held on Weisser Sonntag some weeks later. This way of dividing first communion into two parts had been spreading to many other communities in recent years, and Pfarrer Kreis is keen on trying it again after last year's success. This ritual only includes the main participants, the communion children and their parents, no other family members, no relatives, just mother, father and the one child. This underlines the intimacy and exclusiveness, but also the intensity of this $\mathrm{Ge}$ meinschaft.

The room is festively decorated. On the walls hang large biblical pictures drawn earlier by the children of the different small groups. The long tables are covered with white paper table cloths, vases with beautifully arranged flowers stand on each table. The children sit between their parents and each child holds a candle. Pfarrer Kreis welcomes them all, when they have seated themselves, saying how glad he is that so many have come (only three families refused). The Mass is, as usual, held in its two parts, Wortgottesdienst, Low Mass ('word service'/Low Mass), and Holy Communion; the Wortgottesdienst is elaborated some through the participation of the children, which replaces the sermon. The first psalm is sung 
by everyone, then the repentence is declared and prayers of forgiveness said. The children come forward to the Pfarrer who is sitting in the middle of the front table, one by one, holding a burning candle as an offering, and each says aloud a prayer which he or she has written down on a small piece of paper, thank-you Jesus that we have gathered here, Lord Jesus let us all be well.

The children sing and say prayers alternately. One girl becomes tonguetied and her mother gives her a shove in the side, whispers with some show of anger and embarrassment to get her to open her mouth, but to no avail. Another little girl sits listening and watching intently, her hands clasped. She does not say a word either, but her parents do not bother her, they smile at each other and the three of them give a very devout impression. Close to me sit Nina Berthold and her parents. Frau Berthold is a heavy woman, friendly and a bit shy, her husband is a skinny man, on the other hand, and Nina looks more like him. He seems very fond of his daughter, patting her on the shoulder, stroking her hair a few times, and Frau Berthold nudges her gently to make her listen to the Pfarrer, which she herself seems intent on doing.

Pfarrer Kreis goes round to each one and distributes the Holy wafer instead of everyone scrambling to where he is sitting. When he comes to the Bertholds, Herr Berthold holds out his hand self-consciously and when the wafer is laid in his hand he looks a bit anxiously at his wife as if asking what to do next. She points to her mouth and he grins in embarrassment and puts it in his mouth. Herr Haupt happens to see this and laughingly tells those he is sitting together with afterwards about der Manfred, he can not have been to church in this life! They all find it hilarious.

When the Mass is over, bread and wine of a more profane nature is served, people next to each other start associating and talking. It then becomes noticeable that the seating arrangement tends to rearrange itself along class lines, in particular the 'upper strata' which is in a minority, cluster around Herr Haupt. He has seen to it that he controls the Pfarrer's two bottles of very good wine. As the adults sit and talk and drink wine the children run around chasing each other, wrestling, yelling and laughing. The noise they accomplish is at times immense but there is no attempt to quiet them down or make them stop running around. Only Pfarrer Kreis tries once but this has no effect. No one seems to be bothered by the children, on the contrary it is accepted as something natural. As Frau 
Mann, the teacher's wife, had said of last year's occasion, die Kinder haben sich so richtig schön ausgetobt ('the children really had a wonderful time romping about'). At a junction like this children and adults part company for a while.

But behind them is the church, with the family, the kindergarten, and the school, those institutions which formulate specific claims on the child. The church, through its active practitioners, sees itself as having certain prerogatives of controlling social life, it becomes a kind of manager of morality, and a deputy state, as it were. In describing particular events I have tried to show how the church makes itself a part of the personforming project, and not without conflicts, tries to define the limits of the individual. 


\section{7}

\section{Concluding remarks}

Throughout the preceding chapters I have emphasized the centrality of the concept of Erziehung and attempted to show how it is conceived within a cultural discourse on the person. Erziehung is hailed as that foremost process which forms the child into a good person, making society possible. In a deceptively simple manner, a statement by Kant summarizes what it all seems to be about, Der Mensch kann nur werden durch Erziehung. Er ist nichts, als was die Erziehung aus ihm macht ('the human being, or the person, can only 'become/be' through upbringing and education. The person is nothing except what the upbringing makes of him') (in Rutschky 1977:59).

As a project, Erziehung houses conceptions which unfold the individual within a social order, a social whole, to which the individual is thought to relate both subordinately and autonomously. I have tried to uncover the contours and content of this project as it is worked on in the sayings and doings of parents and educators in Linden. I have also, to some extent, attempted to trace its connections with those historically variable and complex sets of ideas and values which Dumont and others have found particular for 'German ideology'. This is an attempt to find a resonance for the Linden discourse in a context beyond its own immediate horizon. Many educators of today, as well as the people of Linden, may consider themselves to be a far cry from some of the ideas prevalent during the last century or the present century. But my assumption is that it may not always be such a far cry, that changes and differences are not as great as they may seem to people. This is not meant as a plea for an unproblematic 
continuity, nor that there is an objective reality against which I have the privilege to check if people are deluded or not. The notion is simply that the reproduction of concepts and meanings in Linden links it to a more encompassing discourse. Perhaps it is well to briefly recapitulate some of the salient features of this educational and ideological discourse, which to some extent transcends time and space.

During the 19th century it became a definite preoccupation among various intellectuals and the bourgeoisie to consciously form and educate children, something which has become essential in all social classes the more school education has spread and been made compulsory. This has not only, or primarily, been for the children's own sake, so to speak, but for the sake of society. The betterment of the individual is for the good of the state. There has been a complex oscillation of thought between the Entfaltung der freie Natur des Kindes ('the unfolding/development of the child's free nature'), as this has been variously conceived, and the seemingly more hierarchical and authoritarian striving to inculcate a certain amount of 'facts' and norms in the children.

Fröbel and Fichte, two prominent if also disputed figures in the earlier public discourse on upbringing and education, can be seen to represent many of these ideas and values which have permeated the notions about forming the person. For them as for others, it was of great importance to find the right means of creating the good citizen for the good of society. Fröbel took the mother and nature as the main principles and actors in his educational project, whereas Fichte may analogically be said to be more father and state oriented. In such a vein, together with a strong concern with problems of establishing national unity, other pedagogues clustered in various constellations. But they were all concerned with defining and controlling the 'natural order' of things through which individuality and freedom may evolve, and in turn be controlled. Nature was appealed to in different ways, as also the nation and the state. To some extent, this coincided with the political and economic transformations of Germany during the 19th and 20th centuries, but also antagonistically.

Non-Germans will perhaps tend to think that all Germans are prone to subordinate to the state, and certainly there has been, and in a way still exists an idealization of the state as the supreme authority and protector of German political and cultural interests. There are, however, also both fierce and uncompromising protests and attacks against the state, as there 
are more complacently critical manifestations in the form of, for example, the so-called Bürgerinitiative ('citizens' initiatives'). Among critics, democracy has been seen as a phenomenon Germany has had difficulty in managing. This is part of the complexity of 'the German Question' as discussed, for example, by Dahrendorf (1969), alluding to the authoritarianism of the German state. Nowadays, democracy is hailed as the hall-mark of German politics, also declared as something school children must learn. But when democracy reigns, this may also be seen, or felt, as a lack of wholeness and unity, and the state, for all its defects, may then be taken by people as a necessary reinforcement or replacement of what a national totality has at times been thought able to achieve. The controversial question of the boundaries of Germanness arose recently when the Kohl government in 1989 declared that all national Germans were already fully-fledged citizens of the German Federal Republic. The state legitimizes nationality, but can also disclaim it, the consequences of which can be disasterous, as during the Nazi era. The state appears as a protector of individual rights and freedom and on some level fuses with the person, which it may again attack. It is a process of paradoxes.

During the long period of national and state concerns and conflicts the education of the individual, the child, has then appeared to be one of the main means by which to attain the sought for good society, today 'the democratic society'. Educators and social philosophers have exerted themselves to formulate how this should be done, while the state has controlled the institutions which are deemed necessary. The school, above all, but also the family, which is seen as the crucial value of the sound state. To mention but one example, Kerschensteiner, the inspector of school administration in Munich during the first half of this century and an instigator of the vocational school, found it essential for the maintenance of the state that its subjects were brought up and educated in the spirit termed bürgerliche Erziehung ('citizen education'). And it is also, as he saw it, "the duty of the family to serve the idea of the state" (1912:20).

In post-world war times, there have been several more or less heated debates about Erziehung, to a great extent concentrated on the organization and curricula of the schools. Means and aims have changed vocabulary. There have been changes in content and practice, and worries about the excessive 'pressure to achieve' (Leistungsdruck) and the necessity of attaining 'equal opportunities' of education (Chancengleichheit). But there 
seems to be, nonetheless, a preoccupation with the deeper meanings of Ordnung and Lernen, in the sense I have tried to show in my analysis. That is, the conflicting demands for individual autonomy and capability and the necessity to subordinate oneself to a given order.

Ein richtiger Mensch, ('a real/good human/person'), must continuously be re-created through the concepts which describe the person. For Lindeners, forming, or making, the person is individually a finite process, but culturally an infinite endeavor and it works through conceptions about the order of life and nature, of individual and society, and the limits of freedom. Children are not yet real persons. They need a long period of formation and the necessary confrontation with 'reality', with life, as it is understood by adults. Children must be made lebensfähig ('fit for living') to be able to mantel the responsibility of being part of society. This process of making lebensfähig works through notions about order, inner and outer order. Outer order creates inner order and is in turn re-created by this inner order. Ordnung is unity and individuality. Selbständigkeit, independence, this particular and significant trait in the accomplishment of personhood, is attained only by being part of this unity. It is an idealized adult world where all is one. Children are a reality, both loved and laughed at, and reprimanded and manipulated into embodying the idea of the good person. In its various details this works to a great extent through the ordering of the body and the ordering of things, the physical structuring of the room.

The body is a natural and a moral body. From the very beginning in life the notions which define nature and morality make themselves felt on the body, society makes itself known. Through manifestations of bodily pleasure, that of sucking, and of dependency, the small child seems to both affirm wholeness and threaten to disrupt it. Through too much closeness the child invades the body of the mother and exaggerates family exclusiveness and its own anti-social dependency, so to speak, denying the "hard life'. By manipulation of the body the child comes to learn about the various facets of Ordnung and its body as a social and ideological construct, and is thereby prepared to attain the virtues of Selbständigkeit.

Good things to eat, snacks and sweets, which Lindeners so often give their children, both underline and bend the boundaries of the ordered body and the ambiguity of closeness and authority. It is the adult who has the privilege and the authority to give and direct pleasure, but it would be 
too limited to see this as just a conscious show of control and authority. The adult, particularly as kin, is also reaching out to the child for its love and good-will. It is an on-going gesture in which the pain and inevitability of growing up and learning is symbolically, and momentarily, erased.

But the child who wilfully denies the benevolence and the goodness of the adult will find the image of its body sorely disarranged. The disobedience, disorder and anti-sociality of Struwwelpeter and his comrades are depicted as bodily disfigurement and ugliness. The political counter-part of this disobedience and disorder may be seen symbolized in the portrayals of the terrorists of the RAF. On the posters of the 'most wanted terrorists', which were put up on many public buildings, the photographs of the terrorists portray them as depressingly sullen and ugly. Attacking the state is as if attacking the natural order of things, and one's body is thereby 'naturally' attacked, that is, disarranged. The immoral body, as that of the 'enemy of the state' is the dark, disfigured, unkept body.

The body is also a sexual body, but sexuality is ambiguously conceived for it is claimed to be something natural and good, and can be transformed into something subversive of the social order, both in the form of the obscene and joking spectacle and in the form of pleasureseeking and passion. This includes both men and women, boys and girls, but girls and women are to some extent set apart, at least in a pedagogical context. Or else there seems to be a tendency to minimize difference by referring to the naturalness of sexuality and the naked body. Women's sexuality may become offensive when it is seen as 'unproductive' in comparison with that of men, which became the problem for Herr Stein at the seminar on sexuality (chapter 6). Pleasure-seeking is then unproductive or meaningless, as if it implies turning one's back on the natural social order, giving way instead to self-centeredness - being like the small child who has not yet learnt 'to be in a group'. People of Linden will at times have difficulty in reconciling the contradictions which are embedded here, for they also want to think of themselves as modern persons who live according to their own choice, not hedged in by seen or unseen authorities.

The ordering of the room, as the ordering of things, is like an extension of the ordering of the body. Both in the home, in kindergarten, and in school each thing has its right place and should be kept there when not in use. It is in the nature of things that they have their special place and an important aspect of the pedagogical endeavor is to make children learn 
which place for which thing at which time. Aufräumen is an activity which links kindergarten, and school with the home. And in the home each room is bounded in relation to the other rooms, doors are often kept closed and visitors never enter or see any other room than the kitchen or the living room. Things and persons do not float around unboundedly. Yet, on the other hand, the capacity for creating an untidy house and Hof ('yard') can be great in some households, disapproved by others but accepted, and disorder through 'wildness' is appreciated and felt to be natural. Notions about creativity, as it appears in kindergarten, for example, are perhaps understandable in relation to this. It is admired and sought after, like pleasure, but it is unpredictable and can turn out to be disruptive of the social or pedagogical order.

The encompassing activity of creating forms of order, which is part of the cultural logic of the various institutional phases of Linden life, divulges, and works on, an underlying contradiction between the perceived assertiveness of the individual and the demands of the collectivity. The individual is thought of as autonomous but is dependent on a benevolent whole, and the range of benevolence is a crucial issue. In Western individualistic thinking the relation between individual and society is one of conflict, and has been a central issue in Western social science, to the detriment of our capability of understanding non-Western peoples (as the debate on the nature-culture/male-female dichotomies has made us more clearly aware). Individualism values equality and the autonomous person, and the blessings of change and progress, but individualism has not always been, nor is, everywhere the same in the Western world. German individualism is a special case, as Dumont attempts to show. There appears a particular tension, or conflict, between egalitarianism and hierarchy in German modern ideology, as if a residue of bygone days lay buried in its modernity. Quite simply, there has then been a tendency in German thinking to think not only individualistically, but also holistically ('societally'). That is, being German has ideologically been primary to being an autonomous and equal individual. Attributes of the person would then be judged in relation to the person's capacity of being German, so to speak. Such views on German ideological history have influenced my understanding of Lindener's notions of the right and good life and the span they perceive between individual and collective.

For anthropology, the problems of re-creating field experiences into 
a text which is meant to relate in some reliable way to the lives of people one has studied are bound to the fear of being untruthful and irrelevant, and to the necessity of tolerating uncertainty. One claims that the people exist irrespective of oneself, yet they become subject to the outsider's power of description and interpretation. In the process they are transformed into something not of their own making, or asking. Recent discussions in anthropology on this and related subjects have been many and varying. Earlier accounts of techniques of participant observation and attempts to circumscribe 'the native's point of view' have been replaced by a growing concern with the anthropologist's point of view (at times referred to in terms of 'reflexivity') and the subsequent problematics of the anthropologist as author (cf. Clifford and Marcus 1986, Marcus and Fischer 1986, Roth 1989, Spencer 1988, to name but a few recent works and comments on these issues). No longer can the anthropologist, or ethnographer (the term more often used in this context) claim a detached position. This has implications for how descriptions and interpretations are deemed relevant as well as the possibility for making generalizations.

Doing fieldwork usually means moving your daily life somewhere else, yet somehow losing track of it while invading the lives of others and letting them invade yours. It is a strange process and stranger it seems when attempting to sift it into a text. Usually descriptions of fieldwork methods and experiences are, as I see it, difficult to connect with what is in the text. How does the reader come to know what made you take up certain leads and drop or lose others? What kinds of descriptions are necessary to asses this? Constructing the text, that is, giving content a form, is coping with the problematics of faithfulness and relevance, which has both ethical and analytical dimensions. What is a good, or 'true', description? How faithful is the interpretation to the description? And how much of this truth and faithfulness can or must be abandoned for the sake of relevance? I refer here to Sperber's (1987) terms but use them in a simpler manner and without being able to reconcile myself with his more ambitious attempt at establishing the scientific status of anthropology.

In my case, some painful problems of description and interpretation arise when assuming that Linden daily life and educational institutions are meaningfully linked to more overarching ideas and valuations about the formation of the person and the relation between individual and society. 
I look for patterns, something beyond individual idiosyncracies, and I have pushed my material hard in particular directions. Too hard? Are the details of the descriptions necessary? Have I left things out which would have made a difference? Can the reader see the connections between description and interpretation? What questions will the readers of Linden pose? Considering such questions means reading the text again, from another perspective than in which it was written (an endeavor I would be greatly interested in attempting at some future point). The descriptions in my text center on certain events and certain individuals. The individuals are made to embody that which is beyond their own selves. The events do not contain a totality of events. They can, in a sense, be 'true' only to themselves, yet it is a truth which is at the mercy of my interpretation. They are made to say more than they observably do, or say other things than the actors may have thought probable or possible. The events and individuals I have taken as representations of and for my analysis, reflect my understanding of meanings and contexts in Linden, and the limits I have set to the problem which concerns me, the ideology and practice of their pedagogics. The teachers, the few experts, the parents, the priest, the groups of children and the events which they created are recreated on my ethnographic arena.

The priest, or a teacher like Frau Heim, for example, are problematic because they may be seen in one way or another as going beyond the limits of Linden 'normality', they could be said to be 'extreme' in their contexts. Many other teachers would not want to be likened to Frau Heim, as it were, and my intention is not to do that. My point in using her is that she is deeply merged in Lindener's experiences of early school life. By interacting with her, the children are made aware of what is possible in the social world in which they live. As I see it, they come to know more extensively about the nuances of praise and punishment, and the relation between inner and outer order. The links and the boundaries between family and school become apparent, in this case perhaps more acutely than would be the case with another teacher. And it is through the school that the state first presents itself in a more concrete manner to the child.

Through a description of some of the details of growing up in a family and the ordering of the body which this entails, the problematics of dependence and independence are underlined. This is assumed to appear through the contradictory efforts to separate the child from the mother (the body of the mother) and bind it to the family, concretely, and to the 
idea of the family. The specific endeavors of kindergarten then introduce the child, and the reader, into the greater intricacies of the meaning of independence and realism. The limits of the individual in relation to a social whole are drawn and the conflicting virtues of individual autonomy and uniqueness and subordination come to the fore.

As I perceived them, Linden notions of person-forming are imbued with concerns about the good society, the freedom of the individual, and the sometimes impenetrable workings of the state. General political debates and events are transformed into their own events and debates. It has been my aim to show through the events and individuals who occur in my descriptions how people in Linden form a world that is forming them. In their strivings to bring up their children and make persons of them, they are confronting ideas and values which transcend the limits of Linden, as they transcend their individual lives. 


\section{Notes}

\section{Foreword}

1. This event has its dismal irony. The historic date was already taken, so to speak, 51 years earlier, the day of the pogrom in 1938 . No one seemed to publicly remember. In the weekly newspaper Die Zeit (Dec. 29,1989), Richard Chaim Schneider, son of a surviving Jewish family writes of his astonishment at seeing these T-shirts - 'What was this? Did the Germans finally want to admit that they had been there? Then, on Nov. 91938 , during the so-called Reichskristallnacht?'(cf. Peter Schneider's article in Dagens Nyheter 12/2-90).

Without being mystical about dates, one may note the coincidence of Nov. 9 in modern German history - in 1848, when military forces crushed the revolution in Berlin; in 1918 when the socialist leader Scheidemann proclaimed "the German Republic outside the Reichtagbuilding in Berlin and at about the same time Karl Liebknecht, the communist leader, hailed 'a free socialist republic' outside the Royal Castle in the same city" (Bramsted 1972:169); in 1923 Hitler proclaimed a 'national revolution' in Munich on Nov. 8 and the police quashed Hitler's attempted coup on the following day, Nov. 9 (ibid.).

\section{Introduction}

1. It is probable that the problem also lay with me and my situation. Having one's own family in the field is not always easy, a persistent conflict of loyalties arises. Doing fieldwork is to some extent being another person than the one one's family knows and bridging this gap was for me difficult, it sometimes made me afraid of 'the field'.

2. There has in Sweden off and on been discussions about Swedish policy in relation to the Second World War, which was not unproblematic, disturbing the image of the benevolent and honest state. Though Sweden was neutral during the war, it was also a collaborator of sorts, admitting German transports through northern Sweden to occupied Norway; selling iron ore to Germany; and a financial world which did not, it seems, shrink from less open forms of collaboration. Sweden had no small number of Nazi supporters and refugee policy towards Jews was more restrictive than was humane. This has never been a big issue among most Swedes, but it is there and links us to the German past, uncomfortably. Sweden has for centuries had close contact with Germany, both economically and intellectually. In modern times there has been a great admiration for German scholarship and 'ideals'. German was also the first foreign language taught in schools until it was replaced by English in the fifties, thereafter keeping a good second place until the school reforms 
of the 60s. Nowadays, German has lost much of its foothold and Germany is not particularly well-known in the younger generations, although this is again changing now that Europe and Germany are being transformed - recently, there have been suggestions by members of the cabinet to again make German a compulsory subject in school.

3. Generally, ideology, as it appears in many contexts, refers to sets of ideas and opinions or values which people more or less consciously adhere to in their attempts to evaluate, motivate, or explain the conditions of their social world. As Geertz says, "...it is through the construction of ideologies, schematic images of social order, that man makes himself for better or worse a political animal" (1973:218). Ideology carries connotations of justification and faith which are not readily questioned. Bloch (1986) notes that ideology involves domination and has a legitimating function related to specific forms of activities and communication, such as ritual. But he does not accept Marxist notions of 'false consciousness' - "if we are to see ideology as mystification, we have to face the fact that in most cases the power-holders are as mystified as anybody else" (ibid.:177). According to Dumont ideology is "the totality of ideas and values common to a society or to a group of people in general" (1977:7). His emphasis can be said to lie on values and on totality. But problems have been raised by Dumont's overarching and somewhat idealistic approach. He has been criticized for assuming that idcologies are too coherent and simple schemes of thought, and for his lack of an analysis of social context and relations (cf. Béteille 1986, Bloch 1986, Kapferer 1988). There is always a risk in taking grand sweeps, as Dumont does, for they never seem to relate in any comprehensible way to the culture of daily life; yet it would be a shame if no one tried, we would have that much less to think about. And as Kapferer (1988) notes, Dumont's problematization, in a comparative vein, of Western modes of thought is significant for the analysis of modern political ideas and nationalisms. But Kapferer qualifies Dumont's view of ideology by relating it to a conception of ontology. "The ideas that are brought into ideological relation may have a grounding in a variety of different ideologies", he writes, and emphasizes that "ontology realizes its meanings, and exerts the force of its logic, only through the ideological action of human beings in a social and political world" (ibid.:80). As the concept of ideology appears in my analysis, it refers both to the encompassing ideas and values which Dumont denotes 'modern ideology', that is, individualism, in its assumed German variant, and to particular thoughts and practices of person-forming in Linden as they seem related to this more general ideology. In my attempt I am necessarily influenced by such views as those of Bloch and Kapferer.

\section{Chapter 1}

1. With this preoccupation follows, one could presume, the many cross-cultural studies of child-rearing methods, as well as the attempts to explain 'national character' in terms 'of personality traits formed through child-rearing methods.

2. Briggs 1970, Fortes (1938) 1970, H. Geertz 1961, Middleton 1970, Schildkrout 1978, to name but a few. 
3. Cf. Carrithers 1985, Geertz 1973, Harris 1989, Howell 1985, 1990, Kapferer 1988, Marcus and Fischer 1986, Riesman 1977, Rosaldo 1980.

4. See for example, Gearing and Tindall 1973, Jahoda and Lewis 1985, Mayer 1970, Middleton 1970, Ochs and Schieffelin 1987, Schildkrout 1978, Schwartzmann 1978, Spindler 1974, Toren 1985.

5. For a few examples of assumptions about such more or less one-way correlations, see Spindler (1974). See Schwartzmann (1978) for a critique of the functional bias in the study of children's play.

6. As M. Strathern notes in a critical discussion of initiation rituals and conceptions of the person, in many analyses the child is seen as "somehow a pre-social being which must be socialized into society" (1988a:11-12 ), society becomes a 'thing' to enter and to leave, something outside the person. In her recent book, The Gender of the Gift (1988b), Strathern develops her comparative, and critical, analysis of 'individual', 'person' and 'society' more fully.

7. Perceptions of the needs and wishes of children and the way adults and children do, and should, interact vary quite extensively - from the playfulness and the covert control of emotions among the Inuit, as Briggs (1979) describes it (cf. also 1970), to the more direct forms of control and circumscription of movement found in many studies of Mediterranean areas, for example, Campbell's study from 1964 (1976) and Du Boulay (1979), even if these are not specifically oriented towards the study of socialization processes; see also in Middleton 1970; and Hendry 1986.

8. As for Linden, emotions are mainly conceptualized, or explained, in terms of biological sensations, 'nerves', 'energy', 'sensitivity', or in terms of outer forces: the weather, coffee, the environment. Expressions and thoughts about emotions (a topic that is now being more specifically focused in anthropology, cf. Lutz and White 1986) are not so prevalent in my material, the person stands forth more in his or her ideological garb and emotions have rather become my privilege. That is, I make certain implicit, or explicit, assumptions about what people may feel in certain situations; I did not focus my questions on their feelings.

9. In Western societies generally, there seem to be certain non-gendered ideals which permeate our lives, making us more tuned in to the notions of the potentials, powers, and destructiveness of being an 'individual'. Simultaneously we are almost drowned in a commercialization of masculinity and femininity which deindividualizes any man or woman through an exaggerated exhibition of impersonal bodily traits.

10. See, for example, Dahrendorf (1969), Dumont (1986a), Elias (1978), Mann (1969), Mosse (1963), Ringer (1969). 
11. Cf. Weber's well-known definition of the state as "a human community that claims the monopoly of the legitimate use of physical force within a given territory"; "the state is a relation of men dominating men", and "if the state is to exist, the dominated must obey the authority claimed by the powers that be" (1970:78). Other definitions may be more based on relations of production and forms of repression. However, a problem for anthropology is the analysis of the workings of the state in relation to the everyday life of particular people. In my case, I have kept to notions about the state current in Linden. The state is then both taken as a given, unproblematically, and seen as a cultural and ideological construction. Its mechanisms of control, force, and protection make themselves known to Lindeners symbolically and concretely.

12. In this way, it is not what Bloch (1986) would call looking at 'real history', which is what he has attempted to do in his very ambitious analysis of changes and continuities of the Merina circumcision ritual through two centuries. Instead I consider certain ideological coincidences, as I interpret them, between pedagogical ideas as they have appeared in some writings and the local discourse on upbringing and education found in Linden.

13. Rousseau has perhaps always been a controversial figure. For some, he is idealized as the apostle of the freedom of the developing individual, whereas others, such as Bertrand Russel, take him as a forerunner of Nazism.

14. See for exampel Lunzer (1976), and Varma and Williams (1976). Some anthropological studies of socialization have also made use of Piaget. A recent one is Hendry (1986). An earlier study of child-rearing in a Norwegian community, Hollos (1974), takes a more critical stance towards using Piaget's cognitive and developmental models since they often do not, as she sees it, problematize the social world.

15. As Cleverley and Phillips(1986) write, "'To attain freedom, Rousseau held, the earliest education must be negative: 'It consists, not in teaching virtue or truth, but in preserving the heart from vice and the spirit from error' (Rousseau)" (ibid.:35).

E.M. Arndt, writer and pedagogue, was a contemporary of Fröbel and ideologically close to him (see Fröbcl and Pfachler 1982; Krieger 1957). Later pedagogues inspired by Fröbel, are, for example, Lietz 1868-1919, the founder of the boarding school (cf. Fröbel and Pfaehler ibid., Mosse 1966), Kerschensteiner 1847-1932, the founder and developer of the vocational school, himself school director in Munich. They were all also concerned with a nationa! education, the upbringing of good citizens; see, for example, Kerschensteiner on Staatsbürgerliche Erziehung der deutschen Jugendlichen ('citizen upbringing of German youth') from the beginning of this century (cf.1912). He was also invited to Sweden to speak about vocational schools. This was subsumed under current Swedish notions about 'education for fitness to live' (uppfostran till livsduglighet.)

16. Fishman and Martin (1986), in their comparison of education in the two post-war 
German states, also consider 19th century discourse on education. They see Schleiermacher as standing somewhere inbetween Rousseau's conception of 'natural growth' and Herbart's notion of 'absolute morality'. Schleiermacher rather integrates guidance with self-growth, as they see it. According to Fishman and Martin, this comes close to the 'democratic pluralism' of the Federal Republic, whereas education in the German Democratic Republic has come closer to the ideas held by Herbart. This may be, but I would think that Fishman and Martin also tend to idealize the 'pluralism' of West Germany.

17. Cf. Bourdieu's discussion of pedagogy and its imprint on the body, "treating the body as memory" (1977:94); see also Okely's (1978) description of boarding-school pedagogical ideology relating to the control of the details of body movement.

18. According to Hendry (1986), Japanese children are sent outside as a punishment for being bad or disobedient. They are cut off from the 'inside', whereas in Linden this is inverted, that is, punishment means being confined to the house, freedom of movement is greatly circumscribed, and complete control may ensue. 'Inside' in this case 'encompasses' the threat of the outside as seen from a Japanese point of view.

19. See also Beck (1973) whose study of mothers of pre-school children showed that what they found most terrible was if their child should lie, this being the most punishable act; cf. Dahrendorf who considers the demand for honesty as a 'private virtue' (p.286-87), of which he is generally critical. He contrasts this with 'public virtue', which he finds has a greater solidarity and so liberal-democratic potential, something German society, according to him, tends to lack.

20. Métraux uses the term autonomy (1970a), which is perhaps a better translation, but as I see it the term independence has more of 'practice' in it than the autonomy concept. I will to some extent retain the German word, since, as German words often do, it gives a good image of what it is all about - selbständig, to stand on one's own/by oneself.

21. For some, for example the well-known German sociologist Helge Pross (personal communication 1979), who has done several studies of German everyday life (see for example, 1976), this preoccupation with Ordnung has been viewed in general social-psychological terms, as a means by which to create a 'sense of security' in a chaotic world; a way of handling the 'fear of the unknown'; as a 'protection' against the traumas of the war. As I see it, Ordnung could rather be understood as an ontological concern which is ideologically appealed to and reinforced in seemingly very different ways throughout modern German history. In the striving for 'wholeness'/'unity', which Ordnung can be seen to be, there is the constant conflict of how the person, the free individual, is both opposed to and encompassed by this 'whole'. If one should still wish to hold to notions about fear and insecurity one can just as well ask whether this drang zur Ordnung ('desire for order') can instill insecurity or fear rather than appease it. 
22. Learning is a widely used concept both in everyday discourse and within various disciplines, such as psychology, pedagogics, sociology, and anthropology. It denotes an array of relations and conditions. It implies the act of teaching, which is an important aspect of Western notions of upbringing and education. It also carries within it notions about imitation (or 'modeling'), and about experience. My aim is not to enter into discussions about learning theory or what learning is. This has preoccupied many anthropologists studying socialization processes and the 'transmission of culture', and of course, some of those concerned with 'educational anthropology' (see, for example, Calhoun and Ianni 1976, Kimball and Hill-Burnett 1973, Spindler 1982, Wolcott 1982). It is perhaps mainly in the study of language acquisition that headway has been made as to what learners learn (see Wolcott ibid.; cf. Heath 1983, Ochs and Schieffelin 1987, Kulick 1990) As the concept appears in my descriptions and analysis, it implies supervision, teaching, authority, but it also refers to 'good will', that is, the individual's attempt to know, to learn. It relates to ideas and values people hold about person-forming and knowledge, how the right things are made known to children. Lindeners say that children must learn. As I noted earlier, I had less access to the experience of the learners. It is rather the interactions between adults and children, and adult notions about what should be learnt and how this should be taught which is at issue. To some extent I also look at how children seem to interpret and manage these notions and the situations related to them.

\section{Chapter 2}

1. 'The person who does not love and honor the Heimat is a wretch and not worth the fortune/happiness found there'.

Although the word Heimat in ordinary, daily discourse would mean simply the place where one lives, the home or homeland, it does carry emotional overtones in its historical and contemporary connotations which are difficult to catch in a translation. I shall, as writers usually do, retain the original term Heimat. The Heimat is mainly associated with the countryside, 'nature', and home-life. It is a place of security and gives a person an identity. Throughout modern German history it has often been given a sentimental and chauvinistic appeal. The sense of Heimat is connected with 'being German' and notions about Germany, Deutschland, which makes it particularly problematical for 'left intellectuals' who have always been troubled by, or detested, much of what is done in the name of Germany, yet are not immune to a sense of nostalgia for the landscape, one's place of birth, a 'home' for one's identity (see Geisler 1985). Since the early 1970s the Heimat has become politically and culturally 'revitalized' through the increasing concern with the environment, which has engaged people over a broader political arena than that of the 'left' (see Geisler ibid.). Through the decades hundreds of nostalgic Heimat-films have been made in Germany, where the Heimat is presented as an idyllic haven. It was a genre especially exploited during the Nazi era and since then it has been made into a part of the post-war entertainment industry. By the mid-60s, however, there began to appear critical Heimat films, anti-Heimat films. In these films fascism is seen as having its roots in the 'oppressive, apathetic coun- 
tryside. As Geisler writes, "Fascism, they seemed to imply, had descended upon the enlightened city-dwellers from the hills of the Bavarian forests and the swamps of the Lüneburg Heath" (ibid.:38 ). It is not quite that simple, of course, as a recent production tried to convey on a grand scale, a film by Edgar Reitz called Heimat, quite effectively. It is of the genre 'revisionist' historical film, but seems to have been well-received by the 'left', which has given impetus for further debate (Hansen 1985).

2. Since then, the CDU have won the elections in Hesse, which may have changed the views people have about the 'radical' and so disconcerting, somewhow disorderly, Hesse.

3. Dahrendorf (1969), in his particular way, considers peasants to be among the most 'backward' in Germany, that is, the least 'modern in attitudes and behavior', along with women and Catholics. And in his critical controversy with Germany, he finds that there is a 'glorification of the countryside as everything good' and the city as the root of all evil, this being 'a symptom of lack of urbanity' (cf.p.47). As things are in Linden and the whole region, it would be difficult to agree with him.

4. The development of oral history of everyday life, Alltagsgeschichte, has perhaps mainly been concentrated on the study of urban working classes, such as the project in the Ruhr led by Lutz Niethammer (1983) (cf. Farr 1986). In Bavaria there has been a long-term project on Bayern in der NS-Zeit (Broszat et al. 1972-1983; cf. Nolan 1988). This is then the opposite trend in anthropological studies of Germany, which have more often concentrated on rural communities rather than urban areas and not only that, there is a preponderance of Central and Southern Germany, to the neglect of other parts of Germany, as Forsythe critically notes (1986) (see, for example, Nurge 1977). I must reluctantly admit that $\mathrm{I}$ am one in the row of these somewhat unimaginative anthropologists, but defend myself as best I can by assuming it is a graver problem that so relatively few anthropologists have cared at all to study German social life.

5. Although voluntary associations of various kinds are so prolific in German social life, as in Linden, they are not made very prominent in this study. I have limited myself to studying the ideology and the processes of upbringing, and in this perspective the Vereine are less influential than other institutions. School children are members of some associations, and they go with their parents to various feasts, and so on, but it is not, as I see it, as important in their lives as it is in that of the adults. The question is, of course, if it is reasonable to separate adult and child life in such a way.

6. Of late, some anthropologists have made it their explicit concern to study certain topics and events through a problematization of the historical processes of which they are a part, making history into an anthropological topic itself, so to speak (see for example, Bloch 1986, Sahlins 1985). The problem of history is not a new concern among anthropologists, as we know; it has always been part of the debate in one way or another (cf. Tonkin et 
al. 1989; see also Davis 1977). To some extent, the growing interest in nationalism and nation-building, and of the problems of identity which go with this, as with the longstanding analysis of ethnic groups and the conception of 'ethnicity' (Tonkin et al. ibid.), has perhaps intensified this concern, also re-inforced by historians' growing tendency to turn to anthropology for analytical instruments (Medick and Sabean 1984, Sabean 1984, Evans and Lee 1986, to mention just a few of those oriented towards Germany).

7. Considering the not unknown method of forcing children to finish their food until they vomit and then make them eat their own vomit, one can imagine that this is a potent 'memory'. Frau Mann had not experienced this, but there were people in Linden who had. (See Helga Novak's fine book about a small girl's life shortly after the war, Die Eisheiligen (1979), where this also is one of her experiences.)

8. I may be wrong, I may have been the one who was embarrassed.

9. This is a somewhat dubious objective, considering that history is not just there as a package of 'facts', but must be interpreted and so contextualized - the immense problem and painful realization this implies has lately been shown in the so-called Historikerstreit, a controversy of great political significance between historians as to how 'the past' is to be understood. The dispute was initiated by an article in Frankfurter Allgemeine Zeitung in June 1986, by the historian Ernst Nolte, entitled The Past that Will not Go Away, where Nolte in fact disclaims the singularity of the Nazi crimes and the destruction of the Jews, setting them in relation to like crimes in a world perspective, thereby trivializing the whole Nazi era, according to his critics, undoing the links people of today necessarily have to the past, whether as victims or as perpetrators. This revisionism of history has political support in the CDU government, and can be seen as part of an ongoing process of creating a national past and identity of which present-day generations can also be proud. But as Habermas writes, "Can one assume the legal succession of the German Reich, can one continue the traditions of German culture without also assuming historical liability for the form of existence in which Auschwitz was possible?" (Habermas 1988). For a critical discussion of this dispute see for example New German Critique 1988, Öhrgaard 1989.

10. Which even Max Weber endorsed however critical he was of both the bureaucracy and the Obrigkeitsstaat. In 1917, he is worried about the state of German politics. He saw a powerless parliament and a growing bureaucracy. How can democracy be possible with this expanding state bureaucracy, he wonders. Yet his view of the 'ethos of office', the responsibility of the bureaucrat, is quite that of the impeccable Untertan ('subordinate'), and like a formal version of what Lindeners would describe as the goal they set up for their children's behavior - obedience and independence, which leads to, but also presupposes, Ordnung. And without such Ordnung there will be no democracy (Weber 1978, Vol.II:13921404; see Brauns and Kramer 1976, for a summary presentation of the German bureaucracy). 
11. It is unclear if 'lowering birth rates' includes all categories of persons living in the country, that is, also the immigrants, or only 'real citizens'. If so, a country like Germany may be filled with Nachwuchs ('descendants') while political rhetoric disclaims its value.

12. The general political/historical discourse, especially as it appeared in the newpapers during the 70s, referred to the past as something one must 'overcome', die Vergangenheit $z u$ bewältigen. It seems as if this no longer is the appropriate terminology. 'There is nothing to 'overcome', whatever such a naive idea of overcoming the past could mean. We will be harassed by it until the end of time - if not the guilt, then the sin and the shame, which is no less oppressing. The future has a past, we cannot escape that. We can never rid ourselves of Auschwitz' (Sommer in Die Zeit, Nov. 8, 1985).

13. During my stay there was a conference in Aschaffenburg on Hitler, as an attempt to take a critical stance to the ongoing Hitlerwelle while claiming that it is legitimate to study the person of Hitler, nonetheless. At this first conference in what was to be series on political and historical issues, called Aschaffenburger Gespräche ('Aschaffenburger Talks'), prominent and somewhat dubious historians and publicists discussed their views on Hitler and his career (see Knopp 1979). Others found it would be more meaningful to 'look into ourselves' than to engage in research on Hitler's person, his childhood and career (cf. Mitscherlich-Nielsen 1979).

14. There is a problem about this notion of 'talking' or 'telling', that 'no one talks about it'. I think it is virtually impossible to come home from the front and start telling the 'unknowing' about one's sometimes horrendous experiences. Or tell others about the people one has forsaken, hurt, the brutality or the indifference one showed. How do you say it? When? To whom? Shame and guilt are powerful means for not talking, or listening. Another aspect of this may be that people feel things were not so bad, that their experiences do not coincide with the general historical view.

15. This coincides to some extent with the Neidtheorie ('envy theory') current at the time in Germany. By this is meant that other countries would tend to make West Germans more responsible for the Nazi era than the East Germans or the Austrians because of the successful economic growth of the Federal Republic, of which others then would be assumed to be envious (cf. Mitscherlich-Nielsen 1979).

\section{Chapter 3}

1. The sociological and social-psychological study of the family in Germany has been prolific since the end of the Second World War. Work by well-known researchers such as D. Claessens, R. König, H. Schelsky, G. Wurzbacher, are often referred to in the many empirical and theoretical studies (cf. Nave-Herz 1988). Research has been variously tuned to the study of changes and continuities of family structure, and socialization, since the 
establishing of the Federal Republic, but also with a longer historical pespective (cf. for example, Gottschalch 1979, Weber-Kellermann 1974). Also typical is the study of the family as a generalized institution, that is, without a concomitant study of the particular social context (cf. Neidhardt 1975). There have been tendencies to proclaim various crises of the family - its disintegration or dissolution, or its isolation from the rest of society, or its lack of (benevolent) control and authority in the socialization of the children. What seems to be the case is, instead, a development of various family forms, not a dissolution of the family. Marriages may be more problematic, but the general valuation of the family, in terms of the constellation of parents and children, is still high, according to Nave-Herz (ibid.).

My general impression is that studies of the family in Germany mainly have a sociological/statistical and psychological orientation, relying primarily on empirical material from various forms of interviews. Opinions and values are registered and analyzed in combination with economic and social conditions of the family in different social and economic classes/categorics (often termed 'strata', Schicht). And the historical perspective may be shorter or longer, and more or less theoretically overarching. A great deal of valuable material, and interesting conclusions, are to be found in these studies, but I still think it unfortunate that so few anthropologically oriented studies are conducted on the family and 'socialization' in Germany. Such studies could problematize the relation between thought and action; they could establish an on-going discourse about that which people take for granted; and it would perhaps make it less tempting to proclaim different kinds of normative or behavioral crises. Anthropology is not 'truer' or 'better' than other disciplines, but it does provide a method of moving around among the more minute details of everyday life without giving up the analytical attempt at finding underlying patterns of these details. It is the forms and contexts of interactions which the anthropologist studies, confronted with the constant problem of trying to grasp what people say and what they do, and to make sense of their ideas and actions in relation to a wider social world. The project is, of course, doomed to fail if the aim is to find out 'the truth', but it may offer an alternative perspective on known things.

2. According to the news magazine Der Spiegel certain ideological matters have changed little under the surface since the Imperial days:

Mit Stichworten wic Vaterland, Heimatlicbe, Pflichtgefühl, Stolz auf die kulturellen Lcistungen des Volkes; Gewissenhaftigkeit, Flciss, Masshalten, umschreibt Kohl eine seit Kaisers Zeiten ungebrochene deutsche Bürgermentalität, die 'den Staat' - welchem auch immer -gehorsam verinnerlicht hat. (...) Viel neues in der Grundauffassung ist nicht hinzugekommen in all seinen Politikerjahren. Weder Kohls Wendepolitik noch sein 'Geschichtyerständnis' sind von der schon zu Jugendzeiten verfestigten Ideologie zu trennen, in der die nahezu heilige Familie zugleich als Keimzelle und als Modell für den Staat herhalten muss, neuerdings auch für das 'europäische Haus

' ('With head-words such as fatherland, love of the Heimat, sense of duty, pride in the 
cultural achievement of the nation/people (Volk); conscientiousness, diligence, moderation/sobriety, Kohl describes a German bourgeois mentality with its unbroken continuity since Imperial times, which has obediently incorporated the State, whichever it has been. (...) Not much has been added to these basic notions during his years as politician. Neither Kohl's Wendepolitik ('policy of change') nor his understanding of history can be separated from the ideology of his youth where the nearly holy family is held forth as the core and model of the state, now also of the "European house"). (No.47, 20 Nov. 1989:132).

Kohl and people of Linden may see the family as the core of the state, but a critic like Peter Brückner, the social-psychologist, cannot accept this tenet. He argues instead that the state has a tremendous impact on the development of the individual and the family in Germany, he speaks of 'personal character' as being staatsvermittelt ('state mediated') (1978). Cf. Dahrendorf (1969), who refers critically to the dominant value in Germany of the family as the 'germinal cell of the nation' (ibid.:48)

3. In several respects family and household relations and organization, and the importance of kinship relations resemble that which is described in many other European studies, for example, Bailey 1971, Bott 1971 (1957), Cole and Wolf 1974, Strathern 1981, Young and Willmott 1971 (1957), to name but a few.

4. Of the $310-315$ households registered in Linden, about 122 were located in the house of the husband's parents, about 75 in that of the wife's parents, and about 118 were located in a house of their own, near one of the spouse's parents. These are not exact figures. They point to a tendency of 'patri/virilocality', but to make this meaningful and interesting one would have to consider the complex details of economic relations, access to land, age and sex of siblings, changes of locality over time, as well as the occurrence of post-war refugees and latter-day Zugezogene living in Linden. Weatherford (1979), whose main interest is the relation between family organization and emotional behavior, refers to 'joint families' for such residential units comprising two or three nuclear families (either of sibling or parentchild generations), which were common in the town he studied. (Others would perhaps rather refer to them as 'extended families' since they mainly comprise parent-child generations.) He does not, as I do, underline the distinction between shared or separate households. But either as mother/wife or father/husband, it does make a difference whether one controls one's own household or not; a woman 'wants her own kitchen', as a man wants to be 'head of his own family'. However, apart from that, it is important to take note of the common occurrence of such family/household organization, since it has been assumed among many sociologists that the wider family network is no longer a significant unit in industrialized, urban societies.

5. It also depends on where the land is located, as the building of houses is regulated. Villages and towns may not expand their core or their outer limits without municipal control and certain plots are not meant to be built on. 
6. Many studies have shown the importance of the house, which made me more aware of the Linden situation, for example, Du Boulay (1979). The house in the Greek village she studied takes on connotations of the family and the two words are often used interchangeably. The house/family has a much greater cultural significance for people than the village. In Linden there is not such a strong tie between house and family. The house is part of the family image, but also importantly connects the family to Linden, and to a modern life. People decorate and re-decorate their houses, furniture is expensive and fine-looking. The house is like an image of the person and the idea of the family. Cf. Gullestad who has written about the centrality of the house and home in Norwegian culture (1989; see also 1974)

7. Cf. Bott 1971, Frankenberg 1957, Strathern 1981, Young and Willmott 1971; see also Golde 1975, Spindler 1974, Weatherford 1979, for Germany.

8. Cf. discussions and descriptions of various forms of friendship, for example Gilmore (1980), Paine (1974), Weinberg (1975).

9. Mother and motherhood are well-known themes in the German ideology of the family and the nation. The mother has been idealized and hailed as the basis of the good society, and especially during the Nazi era the mother was depicted with a special aura (cf. Allen 1985, Bleuel 1973, Hausen 1984, Koonz 1988). There are also several studies of women as mothers and housewives, see for example, Pross (1976), Sommerkorn (1988).

10. In Germany there have been debates about 'familial authority', and the position of the father. This has been one aspect of social-psychological research, as in the earlier phases of 'critical theory', linked to such prominent names as Max Horkheimer and Theodor Adorno. Modern capitalist society is seen as leading to a deterioration of authority, or as Mitscherlich termed it in the sixties, 'the fatherless society'. This implies that the position of the father is weakening, his real presence and authority diminishes; impersonal institutions and peer groups replace paternal authority. This is interpreted as one of the ills of the commercialized, modern mass society, and it is thought to lead to greater conformity; see Mitscherlich (1969); cf. Benjamin (1978), who critically discusses Horkheimer's work on 'Authority and the Family' (Horkheimer 1949; cf. Jay 1973). A particular problem for Germany concerns claims to paternal authority in relation to the Nazi era. Men fought for, and lost, an evil cause. How can they then make legitimate claims to authority over their children? As for Linden, the position of and ideas about father, fatherhood, and authority, may have changed, but fathers in Linden seem to want to identify themselves as heads of families. They have a family to be responsible for, which gives them a certain amount of prestige, and they tend to speak of themselves as models for their children.

Fatherlessness has also taken on another concrete dimension in this century, since a great number of men died in the wars or were at least away for many years. Women managed on their own without their men, and could find it difficult to give up their inde- 
pendent position when the men returned; cf. Hausen 1984; Langer 1985. (Langer (ibid.) also notes that the family was the only intact institution right after the war, however it was at the time organized.)

11. There is a marked preoccupation with breasts in other contexts. Obscene jokes often refer to breasts, and women are concerned about this aspect of their bodies, hoping their breasts are attractive enough. The nursing situation does transform this publicly sexy breast to a 'naturalness' which is strongly charged emotionally and so perhaps vulnerable. The closeness between mother and child which is displayed at such moments may be what is for some felt to be embarrassing, or deforming.

12. It has been common among many Germans and non Germans to consider the German family in terms of 'authoritarianism'. But I would rather agree with Spindler's (1973) argument, that this only keeps repeating what is already 'known' without problematizing it. In his study in Baden-Württemberg on 'urbanization and identity', he found that the families were more distinguished by a strong sense of togetherness and exclusiveness. (Cf. Métraux 1970c. She also found a marked stress on, and idealization of, togetherness in the family in juvenile fiction.) This need not deny authoritarianism, of course. But by constantly using authoritarianism as a concept for describing all kinds of relations and situations which show forms of control, subordination, dependence, or even severity, reifies it by not qualifying it. It turns into rhetoric. 'Authoritarianism' is not, after all, an exclusively German dimension of social relations. As Gottschalch (1979) points out, as just one example, Adorno's (et al.) study of the 'authoritarian personality', for what it is worth, was based on interviews and tests on mainly American subjects.

\section{Chapter 4}

1. It may be a common view among several German pedagogues that Fröbel's intentions are not lived up to today in many, or most, kindergartens (see for example Flitner 1971, Fröbel and Pfaehler 1982). But this may be underestimating the potentialities of the control mechanisms of the 'free pedagogics' which seemingly sets the child in the center. The striving is, after all, to form the child in relation to the group, which is already preinterpreted by the educator, and to develop its social and intellectual capacities only in relation to this notion of group or society, or person.

2. The snacks and sandwiches the children bring to kindergarten are mainly of a sweet character, sometimes combined with non-sweet bread. What they eat is from home, the mother, and what they drink is from kindergarten. Eating in kindergarten has certain resemblances with eating in other situations in Linden. There is a distinction made in Linden social life between hot and cold meals. There is also a distinction between beverages and solid food. Eating is a kind of secluded, or 'private'/individual, enjoyment, whereas drinking is a more public affair. Kaffee und Kuchen ('coffee and cake') stands in an in-between 
relation to this, as does salt snacks and alcoholic beverages. It combines eating and drinking but in a way which easily reaches beyond family and close kin. It can combine men and women, young and old, as it can combine people who are not related. A stranger may be served a drink (alcohol or soft drink) without encroaching on the 'private sphere' of the individual or the family. A stranger or new acquaintance will not be served a hot meal in a home and one does not eat together with strangers at a public village feast. Hot meals eaten outside the home in public places are conducted as if one retreats somewhat from the public scene. People will not engage in much talk with the one eating, or watch him or her. Dishes may be heavy and large but are usually eaten quickly and without much comment. As one man said to me, 'a German eats like he works'. I did not take him up on this, and I did not continue this line of thought about Linden, but as several anthropologists have shown, food and eating have great social and symbolic force.

3. Research about kindergarten pedagogics (or pre-school education), and 'kindergarten life' in Germany has not been prolific, but it is gaining in importance (cf. Hundertmarck 1978). Much seems to be oriented towards problems of Chancengleichheit, that is, how to accomodate underprivileged children; the organization of kindergartens; means and aims for learning; and towards the problematics of authoritarian versus anti-authoritarian education, cf. Flitner (1971), Hundertmarck (ibid.).

4. The relation between order and freedom appears to be problematic in German thought, as mentioned in chapter 1. Dumont (1986a) quotes Troeltsch's attempt to circumscribe a German idea of freedom, which I find illuminating for my thinking about Linden, even if it is necessarily bound to its historical time (1916). Troeltsch's view of the German idea of liberty is as "an organized unity of the people based on a rigorous and at the same time critical devotion of the individual to the whole, which is completed and legitimized by the independence and individuality of the free spiritual culture (Bildung) (Troeltsch 1925:103)" (Dumont ibid:133).

5. Allegedly, it was on December 6 that the good bishop Nikolaus died in Myra, now the village of Demre in southern Turkey, and so it was told to the children in Kindergarten (cf. Brockhaus 1971, Weber-Kellermann 1974). He lived during the fourth century A.D. and in subsequent centuries has been hailed as a prominent saint in the Catholic Church. $\mathrm{He}$ is variously depicted as a protector of sea-faring traders, of poor and ill-faring children, and as healer of the sick. He is benevolent and knowing. Yet since the $60 \mathrm{~s}$ he is no longer included in the calendar of saints, not being regarded as a saint by the Vatican, and the Catholic Church in Germany, at least, does not officially commemorate him. In Linden there was no church ceremony held in his name; Nikolaus Day was celebrated in the homes and in some associations.

6. In Brücken, the mayor took the opportunity to enhance the political good-will of this new administrative center by staging a small Nikolaus ceremony together with his staff. Con- 
sidering the cost of repairing the old town hall and the ill-feeling which was latent or manifest between the villages and Brücken, this was probably deemed by the staff to be a wise move. Nikolaus came riding on his horse led by his lackey Ruprecht who also carried the rod. He went up to the mayor and greeted him and stood on the stairs leading up to the town hall and held a short speech in verse about the happiness of Christmas, about his own arrival, saying that one should help those who are in need. After that the staff gave the shivering crowd of children Christmas buns.

7. Cf. Handelman's (1990) analysis of Israeli kindergarten celebrations and Weil (1986); see also Hendry's (1986) study of children in a Japanese kindergarten.

8. The didactic value given punishments in public situations makes it appear revengeful, which is nicely depicted in Der Struwwelpeter. Nikolaus is shown to be greatly provoked by some boys who mock and jeer at a black boy. For this misbehavior, intolerance and lack of forgiveness or compassion (for there is no merit in being black), the boys are dipped in black ink, making them even blacker than the black boy, all for their evil ways, and for all to see.

9. Or as Kapferer (1983) writes on ritual, "The ideas in ritual are abstractions from those relevant to, or implicit within, the action of the everyday world and are established apart from it while they might simultaneously reflect upon a routine ordinary world. It is the apartness and abstraction of ideas from their embeddedness in the action of everyday life which creates them as symbolic in a heightened and reified sense, and greatly empowers ideas to structure action to their terms" (p.3).

\section{Chapter 5}

1. After the war, during the $50 \mathrm{~s}$, there were few if any attempts at school reform, whereas the period between the mid $60 \mathrm{~s}$ and early $70 \mathrm{~s}$ was a time of intensified school reform and debate. In particular this related to certain problems of the inner work of the school curriculum, forms of teaching, problems of learning, but also to attempts at new organizational forms. But the general organizational structure of the German school has actually not changed much since the Weimar Republic (cf. Baumert et al. 1984, Klafki 1985; for a historical description of the German school system, see Ringer 1979; for a study of education in East and West Germany see Fishman and Martin 1986, who also make brief links with the 19th century discourse on pedagogics).

2. Taking the school situation as part of my description and analysis means being confronted by a vast amount of school and classroom studies which have been conducted within the social sciences for many years (to some extent also in anthropology, see for example, Calhoun and Ianni 1976, Heath 1983, Roberts and Akinsanya 1976, Spindler 1974,1982 , although anthropology has held to a wider view of education than just formal 
schooling). Many of these studies have attempted to discern what children learn or do not learn, and such aspects as class and ethnicity have entered into the discussions (cf. Lithman 1984, Wulff 1988). Studies of classroom interactions have shown that children learn and experience a great many things which are not 'on the agenda', that which has come to be called the 'hidden curriculum' from Jackson's well-known study (1968), and a great deal of research has concentrated on the dynamics of this. On the other hand, much educational research has taken the overall shool organization and formal curriculum as its main, 'macrocosmic' focus (cf. Masemann 1986; see Altbach and Kelly 1986 for various discussions on the standing of comparative education). It is beyond my aim to discuss these various research trends. However, I consider certain classroom events in relation to my general focus on Linden ideas and values about the person and the practices linked to this.

3. Rechtschreibung is central to traditional German language education and it has a 'high moral rank in most people's consciousness', according to Wünsche (1979), a teacher writing on the subject, and he adds, bitterly, that der Weg in der Sprachlosigkeit führt über eine intensive Pflege der Rechtschreibung (ibid.:21) ('the road to speechlessness/lack of language goes over an intense care of Rechtschreibung').

4. The joke, as Mary Douglas (1975) sees it, referring to Freud and Bergson, is an attack on control, "a play upon form" (p.96). And according to her, "all jokes are expressive of the social situations in which they occur" (p.98). But Douglas' conception of 'expression' may be problematic because she scems to link social situation and symbolization too closely and too unambiguously. If joking (and obscenity) "attacks sense and hierarchy" (p.104), a view with which one can agree, it does pose a problem in relation to some aspects of Linden joking where the superior jokingly attacks the inferior. In this case, the subordinate is taunted by the possibilities of supcriority, and the joke refers to the precariousness of not yet being a 'real person'.

5. Several studies of various educational contexts have noted the particularity of interrogative modes, particuarly in relation to language socialization (cf. Heath 1983, Ochs and Schieffelin 1987).

Asking questions was also a fieldwork problem, making interviews difficult. As a stranger, or outsider, in some ways inferior, one has no real right to pose questions to people, especially about things which encroach on their boundaries. Interviewing may remind people of the interrogating adult and the precariousness of boundaries.

6. Parents will often refer to at least one of their children as being sehr sensibel ('very sensitive'), which is a way of marking out the uniqueness and intelligence of the child. This also makes room for certain excuses of the child's unwarranted or inexplicable behavior.

7. This idea that book-learning demands seclusion and quiet is a widespread notion in pedagogics generally, which by implication denies people who live otherwise the acknowledgement of becoming learned, or even literate for that matter. 


\section{Chapter 6}

1. Herr Bender, a teacher and active in Linden affairs, puts it dramatically, 'God must never be replaced by the self-aggrandizing belief in Man. Man is an incomplete, an imperfect being. If Man is put in the place of God, then this will be the ruin of Man. This is what communism and fascism have done'.

2. Among many of those who confess, particularly the young and middle-aged, it is often said that 'somehow it is all wrong'. They are caught in a dilemma of having to tell the truth, yet finding it often necessary to lie, 'you can't tell a priest everything!' And lying is the worst sin a child can commit in relation to parents. It is also a matter of being forced to succumb to an invasion of privacy which otherwise is strongly rejected. Confession is a transgression of boundaries as well as a restating of them, or a fixation of them. Confession demands that each individual tells of his or her unique sins, but the sins are defined beforehand and pull the individual into a collective orbit. Children usually confess according to a given Zettel ('scheme or agenda') which conveys the different situations in which a child finds itself. The instructions for this are given by the priest, and can be found in the Book of Prayer. The child tells how he or she has acted at home, outside, in school, and in church, that is, confess as to any wrongs committed. Adults are conventionally to follow the Ten Commandments in their confession, but few seem to do this. One admits to some sins, of which the worst is officially not having been to Sunday Mass regularly. What bothers people is the association of confession with sexuality. Not that this seems to be such a common topic of confession itself. But confronting the church and the priest people are made aware of the potential sin of family life, namely sexual pleasure, and so, tales are told of this or that woman who had been asked by a priest about her sexual habits with her husband. The Protestants are almost envied for not having this problem of confession. They have their day of prayer and penance, the Buss- und Bettag and many Lindeners find that this would be quite sufficient for them too. The Buss- und Bettag was devised by King Frederick Wilhelm IV in Nov. 1848, haunted as he was by "a sense of guilt for having 'allowed' the revolution to happen" (Sagarra 1977:214).

3. This is a common observation, mentioned as such, more or less unproblematically in much writing. Attempts to explain this often refer to women's closeness to the care of house and home and the upbringing of children, implying that this brings them closer to the church as if the church stands closer to the 'domestic sphere' than to the 'public sphere'. Superficially, this does seem to fit with the situation in Linden, but it is a circumscribed view of what is domestic and what is public (a dichotomy which has been discussed and criticized in analyses of gender and the particular situation of women, cf. Moore 1989) It should not be taken for granted, analytically, that it is the women who are the upholders of 'continuity and tradition' more than men, or that this is confined to whatever is taken to be domestic. The church is very much a social and political affair, and men and women engage in it from different angels, both in opposition to each other and complementarily. 
4. "For Schiller, man must always remain free and inviolate. Beauty was never chaotic but for Schiller (...) had laws and principles of order" (Mosse 1975:25). Perhaps it is something along these lines which makes Herr Stein refer to Schiller.

5. The $K A B$, Katholische Arbeitnehmer-Bewegung (Catholic Employer's/Worker's Movement') is a nation-wide association which developed during the middle of the last century. In the regional news bulletin of the $\mathrm{KAB}$, Der Welt verpflichtet ('The world claims responsibility'), Ketteler, founder of the KAB, is lauded for his struggle for the workers. Ketteler was critical both of the liberal economic system and of socialism, it is said. He argued that the state must protect the 'natural and social rights of the workers'. On his deathbed, in 1877 , he is assumed to have said: Unsere Religion ist nicht wahrhaft katholisch, wenn sie nicht wahrhaft sozial ist ('Our religion is not truly Catholic if it is not truly social'), (cf. Mosse 1963).

The KAB and its local group, the 'Action Circle', as its youth group, the KJG, formulate directly or indirectly problems of class, politics, belief, and family and Erziehung. The KAB in Linden was forbidden during the Nazi era, but after the war began its work again. Although there are only about seventy paying members in the Linden parish, I assume that their significance is greater than their number; they consider questions and problems which in different ways are important to many people in Linden. Their program of activities includes recurrent meetings with particular topics for discussion. There are also more recreational events organized for both members and non-members, such as the annual autumn hike, the old people's day, and large meetings with invited speakers - expert pedagogues, or perhaps a local CSU politician. The organization is declared politically independent, that is, no political party is officially supported by the KAB, although many members have their sympathy with the CSU. The KAB can also offer a platform on which to build a political career. 


\section{References}

Allen, A.T. 1985. Mothers of the new generation: Adele Schreiber, Helene Stöcker, and the evolution of a German idea of motherhood, 19001914. Signs, 10:418-38.

- 1986. Gardens of children, gardens of God: kindergartens and daycare centers in nineteenth century Germany. Journal of Social History, 19:433-50.

Altbach, P. and G. Kelly (eds.). 1986. New Approaches to Comparative Education. Chicago and London: The University of Chicago Press.

Ambjörnsson, R. 1977. Rousseau och den naturliga människan (Introduction to J.-J. Rousseau, Émile ou de l'éducation). Göteborg: Stegelands.

Anderson, B. 1983. Imagined Communities: Reflections on the Origin and Spread of Nationalism. London: Verso.

Aries, P. 1973 (1962). Centuries of Childhood. London: Jonathan Cape.

Bailey, F.G. 1971. Gifts and Poison: The Politics of Reputation. Oxford: Blackwell.

Barnouw, V. 1963. Culture and Personality. Homewood, Illinois: The Dorsey Press, Inc.

Baum, G. and H. Mahler 1980. Der Minister und der Terrorist: Gespräche zwischen Gerhart Baum und Horst Mahler. Hamburg: Rowohlt.

Baumert, J. et al. 1984. (Arbeitsgruppe am Max-Planck-Institut für Bildungsforschung). Das Bildungswesen in der Bundesrepublik Deutschland. Hamburg: Rowohlt.

Beck, G. 1973. Autorität im Vorschulalter: Eine soziologische Untersuchung zur politischen Sozialisation in der Familie. Weinheim: Beltz Verlag.

Benjamin, J. 1978. Authority and the family revisited: or, a world without fathers?. New German Critique, 13:35-56.

Béteille, A. 1986. Individualism and equality. Current Anthropology, 27:12134.

Betz, H-G. 1988. Deutschlandpolitik on the margins: on the evolution of contemporary New Right nationalism in the Federal Republic. New German Critique, 44:127-57.

Bleuel, H.P. 1971. Kinder in Deutschland. Munich: Karl Hanser Verlag. 1976. Strength Through Joy: Sex and Society in Nazi Germany. London: Pan Books. 
Bloch, M. 1986. From Blessing to Violence: History and Ideology in the Circumcision Ritual of the Merina of Madagascar. Cambridge: Cambridge University Press.

Bluhm, S. 1971. Friedrich Fröbel. The Encyclopedia of Education. MacMillan and Free Press.

Bock, P. 1980. Continuities in Psychological Anthropology: A Historical Introduction. San Francisco: W.H. Freeman and Company.

Bott, E. 1971 (1957). Family and Social Network. London: Tavistock.

Bourdieu, P. 1977. Outline of a Theory of Practice. London: Cambridge University Press.

Bramsted, E. 1972. Germany. Englewood Cliffs, N.J.: Prentice Hall, Inc. Brauns, H-J and D. Kramer. 1976. Political repression in West Germany: 'Berufsverbote' in modern German history. New German Critique, 7:10421.

Briggs, J. 1970. Never in Anger: Portrait of an Eskimo Family. Cambridge, Mass.: Harvard University Press.

1979. Aspects of Inuit Value Socialization. Canadian Ethnology Service Paper, 56. Ottowa: National Museum of Canada.

Brockhaus Enzyklopädie. 1971. Wiesbaden: F.A. Brockhaus.

Broszat, M., E. Fröhlich and F. Wiesemann (eds.). 1977-83. Bayern in der NS-Zeit (vol.1-6). Munich: R.Oldenbourg Verlag.

Brückner, P. 1978. Versuch, Uns und Anderen die Bundesrepublik zu Erklären. Berlin: Verlag Klaus Wagenbach.

— 1987. Avsides: Att Växa Upp i Tredje Riket. Stockholm: Symposion (1980, Berlin: Verlag Klaus Wagenbach).

Bruford, W.H. 1975. The German Tradition of Self-Cultivation: 'Bildung' from Humboldt to Thomas Mann. London: Cambridge University Press.

Busch, W. (1865) 1976. Max und Moritz: Eine Bubengeschichte in Sieben Streichen. Pestalozzi Verlag.

Calhoun, C.J. and F.A. Ianni (eds.) 1976. The Anthropological Study of Education. The Hague: Monton Publishers.

Campbell, J.K. 1976. Honour, Family and Patronage. Oxford: Oxford University Press.

Carr, W. 1979. A History of Germany, 1815-1945. London: Edward Arnold. Carrithers, M., S. Collins and S. Lukes (eds.) 1985. The Category of the Person: Anthropology, Philosophy, History. Cambridge: Cambridge University Press.

Catt, C. 1986. Farmers and factory workers: rural society in Imperial Germany, the example of Maudach. In The German Peasantry. R.J. Evans and W.R. Lee (eds.). London: Croom Helm.

Claessens, D., A. Klönne and A. Tschoepe. 1978. Sozialkunde der Bundesrepublik Deutschland. Düsseldorf: Diedrichs. 
Cleverley, J. and D.C. Phillips. 1986. Visions of Childhood: Influential Models from Locke to Spock. New York: Teachers College Press.

Clifford, J. and G. Marcus (eds.). 1986 Writing Culture: The Poetics and Politics of Ethnography. Berkeley: University of California Press.

Cole, J.W. and E. Wolf. 1974. The Hidden Frontier: Ecology and Ethnicity in an Alpine Valley. New York: Academic Press.

Dahrendorf, R. 1969. Society and Democracy in Germany. Garden City, New York: Doubleday \& Co. Inc., Anchor Books.

Daun, Å. 1989. Svensk Mentalitet. Stockholm: Rabén \& Sjögren.

Davis, J. 1977. People of the Mediterranean: An Essay on Comparative Anthropology. London: Routledge and Kegan Paul.

von Dohnanyi, K. (ed.). 1971. Die Schule der Nation, zur Bildungsdebatte: Fakten, Forderungen, Folgen. Düsseldorf: Econ Verlag.

Douglas, M. 1966. Purity and Danger: An Analysis of Concepts of Pollution and Taboo. London: Routledge and Kegan Paul.

— 1975. Implicit Meanings: Essays in Anthropology. London: Routledge and Kegan Paul.

Du Boulay, J. 1974. Portrait of a Greek Mountain Village. Oxford: Clarendon Press.

Dumont, L. 1965. The modern conception of the individual. Contributions to Indian Sociology, 8:13-61.

- 1971. Religion, politics, and society in the individualistic universe. Proceedings of the Royal Anthropological Institute of Great Britain and Ireland for 1970.

— 1977. From Mandeville to Marx. Chicago and London: The University of Chicago Press.

— 1986a. Essays on Individualsim: Modern Ideology in Anthropological Perspective. Chicago and London: The University of Chicago Press.

- 1986b. Are cultures living beings? German identity in interaction. Man, 21:587-604.

- 1986c. Collective identities and universalist ideology: the actual interplay. Theory, Culture \& Society, 3:25-33.

Dundes, A. 1984. Life is Like a Chicken Coop Ladder: A Portrait of German Culture Through Folklore. New York: Columbia University Press.

Eidson, J. 1983. Club-Life, Local Identities, and Status Relations in a Contemporary West German Community. Unpublished Ph.D. thesis, Cornell University.

Elias, N. 1982 (1939). The Civilizing Process. New York: Pantheon Books. Evans, R.J. and W.R. Lee (eds.). 1986. The German Peasantry: Conflict and Community in Rural Society from the Eighteenth to the Twentieth Centuries. London: Croom Helm. 
Farr, I. 1986. 'Tradition' and the peasantry: on the modern historiography of rural Germany. In The German Peasantry, R.J. Evans and W.R. Lee (eds.). London: Croom Helm.

Fichte, J.G. 1914. Tal till Tyska Nationen. Stockholm: Albert Bonnier.

Fishman, S. and L. Martin 1987. Estranged Twins: Education and Society in the Two Germanys. New York and London: Praeger.

Flitner, A. 1971. Vorschulerziehung. In Die Schule der Nation, K. von Dohnanyi (ed.). Düsseldorf: Econ Verlag.

Forsythe, D. 1984. Deutschland als wenig erforschtes Gebiet: ein Problem in der Ethnologie Westeuropas. Kölner Zeitschrift für Soziologie und Sozialpsychologie, 26 (special issue).

1989. German identity and the problems of history. In History and Ethnicity. E. Tonkin, M. McDonald and M. Chapman (eds.). A.S.A. Monographs, 27. London: Routledge.

Foucault, M. 1979. Discipline and Punish: The Birth of the Prison. London: Peregrine Books.

- 1980. Sexualitetens Historia (Vol.1): Viljan att Veta. Stockholm: Gidlunds. Fragen an die deutsche Geschichte: Ideen, Kräfte, Entscheidungen von 1800 bis zur Gegenwart (Katalog). Historische Ausstellung im Reichtagsgebäude in Berlin. 1979.

Fortes, M. 1970 (1938). Social and psychological aspects of education in Taleland. In Time and Social Structure and Other Essays. London: The Athlone Press.

Fröbel, H. and D. Pfaehler (eds.). 1982. Friedrich Fröbels Mutter- und Koselieder. Bad Neustadt a.d.Saale: Mitteldeutsche Verlagsgesellschaft. Fröbel, F. 1965 (1820-52). Kleine pädagogische Schriften (ed. by A. Reble). Bad Heilbrunn/OBB: Verlag Julius Klinkhardt.

Fächer, J. 1968. Historischer Atlas von Bayern: Teil Franken. Munich: Kommission für Bayersiche Landesgeschichte.

Gearing, F. and A. Tindall. 1973. Anthropological studies of the educational process. Annual Review of anthropology, 2:95-105.

Geertz, C. 1973. The Interpretation of Cultures. New York: Basic Books, Inc., Publishers.

Geertz, H. 1961. The Javanese Family: A Study of Kinship and Socialization. Free Press.

Geisler, M. 1985. 'Heimat' and the German left: the anamnesis of a trauma. New German Critique, 36:25-66.

Gibson, P. 1984. Tradition and Change: Local-Level Politics in Bavaria. Unpublished Ph.D. thesis, University of California.

Gilmore, D. 1980. The People of the Plain: Class and Community in Lower Andalusia. New York: Columbia University Press.

Golde, G. 1975. Catholics and Protestants: Agricultural Modernization in Two German Villages. New York: Academic Press. 
Goody, E. 1979. Towards a theory of questions. In Questions and Politeness: Strategies and Social Interaction, E. Goody (ed.). Cambridge: Cambridge University Press.

Gottschalch, W. 1979. Vatermutterkind: Deutsches Familieleben zwischen Romantik un sozialer Revolution. Berlin: Klaus Wagenbach Verlag. Greiffenhagen, M. and S. 1981. Ein Schwieriges Vaterland: Zur politischen Kultur Deutschlands. Frankfurt/M.: Fischer Taschenbuch Verlag.

Gullestad, M. 1984. Kitchen-Table Society: A Case Study of the Family Life and Friendships of Young Working-Class Mothers in Urban Norway. Oslo: Norwegian University Press.

— 1989. Hjemmet som moderne folkekultur. In På Norsk Grunn, Socialantropologiske Studier av Norge, Nordmenn og det Norske. O. Brox and M. Gullestad (eds.). Oslo: Ad Notam Forlag AF.

Habermas, J. 1988. Concerning the public use of history. New German Critique, 44:40-50.

Handelman, D. 1990. Models and Mirrors: Towards and Anthropology of Public Events. Cambridge and New York: Cambridge University Press.

Hansen, M. 1985. Dossier on 'Heimat'. New German Critique, 36:3-24.

Hausen, K. 1984. Mothers, sons, and the sale of symbols and goods: the 'German Mother's Day'. In Interest and Emotion: Essays on the Study of Family and Kinship. H. Medick and D.W. Sabean (eds.). Cambridge and New York: Cambridge University Press.

Harris, G. 1989. Concepts of individual, self, and person in description and analysis. American Anthropologist, 9:599-612.

Heath, S. 1983. Ways with Words: Language, Life, and Work in Communities and Classrooms. Cambridge and New York: Cambridge University Press.

Hendry, J. 1986. Becoming Japanese. Manchester University Press.

Herder, J.G. 1969. J.G. Herder on Social and Political Culture (ed. and Introduction by F.M. Barnard). London.

Hoffmann, H. (1845) 1975. Der Struwwelpeter. Rastatt, Baden: Favorit Verlag. Hollos, M. 1974. Growing up in Flathill: Social Environment and Cognitive Development. Oslo: Universitetsförlaget.

Horkheimer, M. 1949. Authoritarianism and the family today. In The Family: Its Function and Destiny. R. Anshen (ed.). New York: Harpers and Brothers Publishers.

Howell, S. 1985. From child to human: Chewong concepts of self. In Acquiring Culture: Cross Cultural Studies in Child Development. G. Jahoda and I.M. Lewis (eds.). London and New York: Croom Helm.

— 1990. Gjennoppdagelse av menneskenaturen som et antropologisk emne. Norsk Antropologisk Tidsskrift, 1:17-28.

Hughes, H.S. 1977. Consciousness and Society. New York: Vintage Books. 
Hundertmarck, G. 1978. Soziale Erziehung im Kindergarten. Stuttgart: Ernst Klett Verlag.

Ilien, A. and U. Jeggle 1978. Leben auf dem Dorf: Zur Sozialgeschichte des Dorfes un Sozialpsychologie seiner Bewohner. Opladen: Westdeutscher Verlag.

Jahoda, G. and I.M. Lewis. 1985. Introduction: child development in psychology and anthropology. In Acquiring Culture: Cross Cultural Studies in Child Development. G. Jahoda and I.M. Lewis (eds.). London and New York: Croom Helm.

Jay, M. 1973. The Dialectical Imagination: A History of the Frankfurt School and the Institute of Social Research 1923-1950. Boston and Toronto: Little, Brown and Company.

Jackson, P. 1968. Life in Classrooms. New York: Holt, Rinehart and Winston, Inc.

Kapferer, B. 1983. A Celebration of Demons: Exorcism and the Aesthetics of Healing in Sri Lanka. Bloomington: Indiana University Press.

- 1988. Legends of People, Myths of State: Violence, Intolerance, and Political Culture in Sri Lanka and Australia. Washington and London: Smithsonian Institution Press.

Kaschuba, W. 1986. Peasants and others: the historical contours of village class society. In The German Peasantry. R. Evans and W.R. Lee (eds.). London: Croom Helm.

Kerschensteiner, G. 1912. Medborgerlig Uppfostran (Staatsbürgerliche Erziehung der deutsche Jugendlichen, 1906). Stockholm.

Kimball, S. and J.H. Burnett (eds.). 1973. Learning and Culture. AES Proceedings 1972. Seattle and London: University of Washington Press.

Klafki, W. 1985. Die fünfziger Jahre - eine Phase schulorganisatorischer Restauration. In Die Fünfziger Jahre: Beiträge zu Politik und Kultur. D. Bänsch (ed.). Tübingen: Gunter Narr Verlag.

Knopp, G. (ed.). 1979. Hitler Heute: Gespräche über ein deutsches Trauma. Aschaffenburg: Pattloch Verlag.

Kolinsky, M. 1974. Continuity and Change in European Society. London: Croom Helm.

Koonz, C. 1988. Mothers in the Fatherland: Women, the Family and Nazi Politics. London: Methuen.

Krieger, L. 1957. The German Idea of Freedom: History of a Political Tradition. Chicago: The University of Chicago Press.

Kulick, D. 1990. Having Head and Showing Knowledge: Language Shift, Christianity, and Notions of Self in a Papua New Guinean Village. Unpublished Ph.D. thesis, Stockholm University.

Kupffer, H. 1984. Der Faschismus und das Menschenbild der deutschen Pädagogik. Frankfurt/M.: Fischer Taschenbuch Verlag. 
LaFontaine, J.S. 1985. Person and individual: some anthropological reflections. In The Category of the Person, M. Carrithers, S. Collins and S. Lukes (eds.). Cambridge: Cambridge University Press.

Langer, I. 1985. Die Mohrinnen hatten ihre Schuldigkeit getan...staatlichmoralische Aufrüstung der Familien. In Die Fünfziger Jahre: Beiträge $z u$ Politik un Kultur. D. Bänsch (ed.). Tübingen: Gunter Narr Verlag. Lewis, G. Day of Shining Red: An Essay on Understanding Ritual. Cambridge: Cambridge University Press.

Lithman, Y.G. 1984. The Community Apart: A Case Study of a Canadian Indian Reserve Community. Winnipeg: The University of Manitoba Press.

— 1988. Kämpande kroppar, moraliska kroppar: retorik of social kontroll i den tidiga gymnastiken. Idrottshistorisk Arrbok. Stockholm.

Lowie, R. 1954. Toward Understanding Germany. Chicago: The University of Chicago Press.

Lukes, S. 1979. Individualism. Oxford: Basil Blackwell.

- 1985. Conclusion. In The Category of the Person. M. Carrithers, S. Collins and S. Lukes (eds.). Cambridge: Cambridge University Press.

Lunzer, E.A. 1976. An appreciation of Piaget's work. In Piaget, Psychology and Education. V.P. Varma and P. Williams (eds.). London and Toronto: Hodder and Stoughton.

Lohmann, H-G. 1989. Vanmakt och hopp, brevväxling med M. Frank. Res Publica, 14:166-78.

Lutz, C. and G. White. 1986. The anthropology of emotions. Annual Review of Anthropology, 15:405-436.

Mann, G. 1969. Tysklands Historia Under Fem Decennier. Stockholm: Pan/ Norstedts.

Marcus, G. and M. Fischer. 1986. Anthropology as Cultural Critique. Chicago and London: The university of Chicago Press.

Märthesheimer, P. and I. Frenzel (eds.). 1979. Im Kreuzfeuer: Der Fernsehfilm 'Holocaust': Eine Nation ist Betroffen. Frankfurt/M.: Fischer Verlag.

Masemann, V. 1986. Critical ethnography in the study of comparative education. In New Approaches to Comparative Education. P. Altbach and G. Kelly (eds.). Chicago and London: The University of Chicago Press.

de Mause, L. (ed.) 1976. The History of Childhood. London: Souvenir Press Ltd.

Mayer, P. (ed.). 1970. Socialization: The Approach from Social Anthropology. A.S.A. Monographs, 8. London: Tavistock Publications.

McDermott, R.P. 1977. Social relations as contexts for learning in school. Harvard Educational Review, 47:198-213. 
Mead, M. (1930) 1977. Growing Up in New Guinea. London: Penguin Books.

Mead, M. and R. Métraux (eds.). 1953. The Study of Culture at a Distance. Chicago: The University of Chicago Press.

Medick, H. and D.W. Sabean (eds.). 1984. Interest and Emotion: Essays on the Study of Family and Kinship. Cambridge: Cambridge University Press.

Métraux, R. (1955) 1970a. Parents and children: an analysis of contemporary German child-care and youth guidance literature. In Childhood in Contemporary Cultures, M. Mead and M. Wolfenstein (eds.). Chicago: The University of Chicago Press.

- 1970b. The consequences of wrong-doing: an analysis of story completions by German children. In Childhood in Contemporary Cultures, M. Mead and M. Wolfenstein (eds.). Chicago: The University of Chicago Press.

- 1970c. A portrait of the family in German juvenile fiction. In Childhood in Contemporary Cultures, M. Mead and M. Wolfenstein (eds.). Chicago: The University of Chicago Press.

Meves, C. 1987. Mut zum Erziehen: Seelische Gesundheit - Wie können wir sie unseren Kindern vermitteln? Basel: Herder Freiburg.

Middleton, J. (ed.). 1970. From Child to Adult: Studies in the Anthropology of Education. Austin and London: University of Texas Press.

Mitscherlich, A. 1969. Society Without the Father. London: Tavistock Publications.

Mitscherlich-Nielsen, M. 1979. Die Notwendigkeit zu trauern. In Im Kreuzfeuer: Der Fernsehfilm 'Holocaust': Eine Nation ist Betroffen. P. Märthesheimer and I. Frenzel (eds.). Fankfurt/M.: Fischer Verlag. Moore, H. 1988. Feminism and Anthropology. Cambridge: Polity Press.

Mosse, G.L. 1963. The Culture of Western Europe: The Nineteenth and Twentieth Centuries. London: John Murray.

- 1966. The Crisis of German Ideology. London: Weidenfeld and $\mathrm{Ni}$ colson.

1975. The Nationalization of the Masses. New York: Howard Fertig. 1985. Nationalism and Sexuality. New York: Howard Fertig.

Nave-Herz, R. (ed.). 1988. Wandel und Kontinuität der Familie in der Bundesrepublik Deutschland. Stuttgart: Ferdinand Enke Verlag.

Neidhardt, F. 1975. Die Familie in Deutschland. Opladen: Leske Verlag. Niethammer, L. (ed.). 1983. 'Die Jahre weiss man nicht, wo man die hinsetzen soll': Faschismuserfahrungen im Ruhrgebiet. Berlin: Verlag J.H.W. Dietz Nachf. GmbH.

Nolan, M. 1988. The 'Historikerstreit' and social history. New German Critique, 44:51-80. 
Norman, K. 1986. Review of 'Life is Like a Chicken Coop Ladder' (Dundes 1984). Ethnos, 1-2:111-16.

Novak, H. 1979. Die Eisheiligen. Darmstadt: Luchterhand.

Nurge, E. 1977. Blue Light in the Village: Daily Life in a German Village 1965-1966. Michigan, Ann Arbor.

Ochs, E. and B. Schieffelin. 1987. Language acquisition and socialization: three developmental stories and their implications. In Culture Theory: Essays on Mind, Self, and Emotion. R. Schweder and R. LeVine (eds.). Cambridge: Cambridge Univeristy Press.

Okely, J. 1978. Privileged, schooled and finished: boarding school education for girls. In Defining Females: The Nature of Women in Society. S. Ardener (ed.). London: Croom Helm.

Pollock, L. 1983. Forgotten Children: Paren-Child Relations from 1500 to 1900. Cambridge: Cambridge University Press.

Pross, H. 1976. Die Wirklichkeit der Hausfrau. Hamburg: Rowohlt.

Rabinbach, A. 1988. The Jewish question in the German question. New German Critique, 44:159-92.

Riesman, P. 1977. Freedom in Fulani Social Life: An Introspective Ethnography. Chicago and London: The University of Chicago Press.

Ringer, F. 1969. The Decline of the German Mandarins: The German Academic community, 1890-1933. Cambridge, Mass.: Harvard University Press.

- 1979. Education and Society in Modern Europe. Bloomington: Indiana University Press.

Roberts, J. and S. Akinsanya (eds.). 1976. Schooling in the Cultural Context. New York: McKay.

Rodnick, D. 1948. Postwar Germans. New Haven: Yale Univeristy Press. Roggenkamp, G. 1982. Germans and Gastarbeiter: A Study of Prejudice. Unpublished Ph.D. thesis, Syracuse University.

Rosaldo, M. 1980. Knowledge and Passion: Ilongot Notions of Self and Social Life. Cambridge and London: Cambridge University Press.

Roth, P. 1989. Ethnography without tears. Current Anthropology, 30:555-69. Rousseau, J.-J. 1977. Émile, eller Om Uppfostran. Göteborg: Stegelands.

Rutschky, K. (ed.). 1977. Schwarze Pädagogik: Quellen zur Naturgeschichte der bürgerlichen Erziehung. Berlin: Ullstein.

Sabean, D.W. 1984. Power in the Blood: Popular Culture and Village Discourse in Early Modern Germany. Cambridge: Cambridge University Press.

Sagarra, E. 1977. A Social History of Germany. London: Methuen \& Co.

Sahlins, M. 1985. Islands of History. Chicago and London: The University of Chicago Press.

Schatzmann, M. 1973. Soul Murder: Persecution in the Family. London: Allen Lane. 
Schildkrout, E. 1978. Age and gender in Hausa society: socio-economic roles of children in urban Kano. In Sex and Age as Principles of Social Differentiation. J. LaFontaine (ed.). A.S.A. Monographs, 17. London: Academic Press.

Schreber, D.G.M. 1845. Fyra Gyllene Reglor för Barna-Uppfostran. Uppsala: G. Torsell.

Schultze, W. and C. Führ. 1973. Das Schulwesen in der Bundesrepublik Deutschland. Weinheim and Basel: Beltz Verlag.

Schwartzmann, H. 1978. Transformations: The Anthropology of Children's Play. New York: Plenum Press.

Siebert, J. 1934. Über den kulturellen Entwicklungsgang im Spessart im allgemein, ein Schlusswort. Der Spessart, 3. Breslau.

Sommerkorn, I. 1988. Die erwärbstätige Mutter in der Bundesrepublik: Einstellungs- und Problemveränderungen. In Wandel und Kontinuität der Familie in der Bundesrepublik Deutschland. R. Nave-Herz (ed.). Stuttgart: F. Enke Verlag.

Sontheimer, K. 1989. Grundzüge des Politischen systems der Bundesrepublik Deutschland. Munich: Piper.

Spindler, G. 1973. Burgbach: Urbanization and Identity in a German Village. New York: Holt, Rinehart and Winston.

- 1974. (ed.) Education and Cultural Process: Toward an Anthropology of Education. New York: Holt, Rinehart and Winston.

- 1982. (ed.). Doing the Ethnography of Schooling. New York: Holt, Rinehart and Winston.

Spencer, J. 1989. Anthropology as a kind of writing. Man, 24:145-64.

Sperber, D. 1987. On Anthropological Knowledge. Cambridge: Cambridge University Press.

Strathern, M. 1981. Kinship at the Core. Cambridge: Cambridge University Press.

- 1982. Self-interest and the social good: some implications of Hagen gender imagery. In Sexual Meanings: The Cultural Construction of Gender and Sexuality, S. Ortner and H. Whitehead (eds.). Cambridge: Cambridge University Press.

- 1988a. Making incomplete: A comment on female initiation in Melanesia. MS. Prepared for Symposium: Female Initiation in the Pacific. Org. N. Lutkehaus and J. Roscoe. ASAO Meetings.

— 1988b. The Gender of the Gift. Berkeley: University of California Press.

Tonkin, E., M. McDonald, and M. Chapman (eds.). 1989. History and Ethnicity. A.S.A. Monographs, 27. London: Routledge.

Toren, C. 1985. Recent studies of ethnography of childhood, an annotated bibliography. In Acquiring Culture: Cross.-Cultural Studies of Child Development. G. Jahoda and I.M. Lewis, (eds.). London: Croom Helm 
Varma, V. and P. Williams (eds.). 1976. Piaget, Psychology and Education. London: Hodder and Stoughton.

Warren, R. 1967. Education in Rebhausen, A German Village. New York: Holt, Rinehart and Winston.

Weatherford, J. 1979. Family Culture, Behavior, and Emotion in a Working-Class German Town. Unpublished Ph.D. thesis, University of California.

Weber, M. 1970. Max Weber, Essays in Sociology (H.H. Gerth and C. Wright Mills, eds.). London: Routledge and Kegan Paul.

- 1978. Economy and Society (G. Roth and C. Wittich, eds.). Berkeley: University of California Press.

Weber-Kellermann, I. 1974. Die Deutsche Familie. Frankfurt/M.: Suhrkamp Verlag.

— 1978. Brauch, Familie, Arbeitsleben. Marburger Studienkreis für Europäische Ethnologie E.V. Marburg.

Weil, S. 1986. The language and ritual of socialisation: birthday parties in a kindergarten context. Man, 21: 329-41.

Weinberg, D. 1975. Peasant Wisdom: Cultural Adaptation in a Swiss Village. Berkeley: University of California Press.

Wolcott, H. 1982. The anthropology of learning. Anthroplogy and Education Quarterly, 13:83-108.

Wolff, H. 1905. Der Spessart. Aschaffenburg.

Wörner, G. 1956. Aschaffenburger Jahrbuch, 3. Aschaffenburg.

Wulff, H. 1988. Twenty Girls: Growing Up, Ethnicity and Excitement in a South London Microculture. Stockholm: Stockholm Studies in Social Anthropology.

Wünsche. K. 1979. Die wirklichkeit des Hauptschülers. Frankfurt/M.: Fischer.

Young, M. and P. Willmott (1957) 1971. Family and Kinship in East London. Harmondsworth: Penguin Books.

Öhrgaard, P. Nazism and national identity: a current issue in West Germany. Culture \& History, 4:65-90. 


\section{Index}

A

age $13,56,88-91,97,110,114,136$, $185,190,228$,

Allen,A. 22, 28, 66, 105, 229

Ambjörnsson,R. 21

Anderson,B. 18, 40

Angestellter (employee, white-collar worker) 53,76

anti-authoritarianism 30, 132

anti-Heimat 223

anti-state 37

Ariès,P. 19, 20

Aufklärung (enlightenment) 171, 184, 189

aufräumen (tidy up, clean) 112, 130 $134,141,165,214$

authoritarianism 140, 211, 230

authority $45,103,138,164,178,210$, $212,221,227,229$, autonomy 14, 17, 18, 58, 212, 222

B

Bailey,F.G. 80, 228

Barnouw,V. 4, 11 basteln (hobby work) 106, 107, 126, 127, 154, 201

Baum,G. and H.Mahler 70

Baumert,J. et al. 23, 144, 150, 232

Bavaria 1, 45, 46, 62, 158, 171, 224

Betz,H-G. i

Beck,G. 222

belief 17, 131, 105, 121, 122, 177-184, 201-205, 234, 235
Benjamin,J. 229

Beschäftigung (organized activity) 110, 111, 119-121,125, 139

Béteille,A. 219

Bildung (self-cultivation) 23,24, 40, 41, 231

Black Angels (BA) 190-192

blame $8,11,37,51,56,67-69,145$, 153, 156, 165-168, 201

Bleuel,H.P. 24, 30, 229

Bloch,M. 219, 221, 224

Bluhm,S. 105

Bock,P. 4

body 7, 21, 24-28, 38, 96, 99, 103, 105 , 106, 184-189, 212, 213, 216, 222

Bott,E. 89, 228, 229

Bourdieu,P. 222

Bramsted,E. 15, 23, 24, 41, 64, 218

Brauns, H-J and D.Kramer 225

Briggs,J. 219, 220

Brockhaus 105, 231

Broszat,M. et al. 224

Bruckner,P. 17, 24, 228

Bruford,W.H. 41

Busch,W. 28

C

Calhoun,C.J. and F.A.Ianni 223, 232 Campbell,J.K. 220

Catholic 53, 62, 105, 121, 124, 176, 186, 189-193, 201, 231, 235

Catholic Youth (KJG) 189-193

Catt,C. 48,59

CDU 60, 66, 151, 224, 225

Chancengleichheit (equal opportunity) 24, 144, 174, 211, 231

change $31,87,214$

character (Character) 3, 4, 23, 29, 110, 129, 157, 220, 228

Claessens,D. et al. 17, 22, 64, 150, 226 class (social) 2, 15, 23, 39, 48, 53, 56, 72, 87, 120, 192, 207 233, 235 
Cleverley,J. and D.C.Phillips 24, 221

Clifford,J. and G.Marcus 215

Cole,J.W. and E.Wolf 83, 228

concentration disorder (Konzentra-

tionsstörung) 166, 167

confession 181, 182, 199, 234

creativity $105,127,129,214$

CSU 46, 54, 60, 66, 151, 171, 176, 235

D

Dahrendorf,R. i, 17, 22, 65, 210, 221, 222, 224, 228

Daun, A. 4

Davis,J. 225

democracy/democratic $15,21,46,64$, $65,71,173,210,211,222$

dependence $6,89,94,96,101-103$,

115-118, 131, 188, 216, 230

difference 3, 17, 56, 169, 173-175, 216

Dohnanyi,K. 24, 144

Douglas,M. 96, 131, 233

Du Boulay,J. 220

Dundes,A. 4

Dumont,L. 4, 5, 12-16, 23, 40, 169, 209, 214, 219, 231

E

Eidson,J. 2

Elias,N. 20, 41, 221

emotion 9, 11, 13, 27, 119, 220

energy (of children) 16, 26, 39, 57, 89,

$116,143,169,175,220$

equality 14-17, 161, 170, 174, 214

Erstkommunion (First Communion) 123, 200

Erziehung (upbringing and education) $8,10,14,15,18,22,25,28-43$, $106,115,118,126,144,167,168,178$, 184, 186, 189, 209, 211, 221, 235

Essen/essen (food/eat) 64, 79, 111, 225,230
Eucharist 123, 181, 205

Evans,R.J. and W.R.Lee 48, 83, 225

experience $10,13,41,42,102,116$, $165,170,174,186,223$

F

farming $44,49,53,84$

Farr,I. 48, 224

Fasching (carneval) 27, 55, 78, 161, 178

fatherhood 229

fatherlessness 229

Fichte,J.G. 16, 18, 21-24, 31, 210

fieldwork 1, 3, 45, 63, 145, 215, 218, 233

Fishman,S. and L.Martin 30, 222, 232

Flitner,A. 230, 231

Forsythe,D. 2-4, 66, 224

Fortes,M. 9, 220

Foucault,M. 25, 186

freedom 16, 19, 21, 36, 39, 61, 72, 133, 142, 145, 191, 203, 211, 221, 222, 231

Fruhschoppen 96, 180, 199

Fröbel, F./H.Fröbel and D.Pfaehler

21-24, 28, 40, 105, 142, 210, 221, 230

Fächer,J. 62

G

Gearing,F. and A.Tindall 220

Geertz,C./Geertz,H. 219, 220

Geisler,M. 223, 224

Gemeinde (municipality, community) $53,66,78$

Gemeinschaft 7, 23, 59, 106, 149, 182, 183, 191, 192, 200, 201,203, 206 gender $13,14,56,58,87,220,234$

German Autumn 69

German question 65, 210

Gibson,P. 2

gläubig (believing/believer) 105, 180, 195 
Golde,G. 4, 229

Goody,E. 163

Gottschalch,W. 63, 227, 230

Greiffenhagen,M. and S. 17

Grundschule (primary school) 150 guilt (Schuld) 8, 33, 68, 69, 186, 226, 234

Gullestad,M. 229

Gymnasium 53, 150, 191

$\mathrm{H}$

Habermas,J. 225

Handelman,D. 232

Hansen,M. 66, 224

Harris, G. 12, 13, 220

Harvest feast 197-199

Hauptschule (lower secondary school) 150, 191

Hausen,K. 48, 229

Heath,S. 10, 119, 223, 224, 232, 233

Heimat 44, 61, 193, 223, 224, 227

Hendry,J. 10, 22, 220, 221, 222, 232

Herbart 24, 29, 222

Herder,J.G. 16, 2123

Hesse (Bundesland) 1, 44-46, 58, 60, $62,75-78,108,120,151,191,224$

hierarchy 41, 131, 214, 233

Hitlerwelle (Hitler-wave) 67, 226

history 5, 6, 16, 20, 21, 23, 48, 61-67, 214, 218, 221, 223-225, 228

Hoffmann,H. 27

holism 17, 71

Hollos,M. 221

Holocaust (film) 66-68, 202

homework (of school) 33, 81, 147, $153,154,160,167$

home-work (of paid work) 50-52, 79 honesty 8,222

Horkheimer,M. 229

hospital 46, 101, 102

house $6,38,61,85,222,228,229$

Howell,S. 11, 12, 220
Hughes,H.S. ii

Hundertmarck,G. 106, 231

I

identity $1-6,16,19,23,24,61,62,71$, $72,223,225,230$

ideology 3, 5, 7, 10, 12-24, 30, 71, 104, 116, 124-126,133, 174, 209, 219, 222, 227, 229

Ilien,A. and U.Jeggle 48, 53

imagination (Phantasie) 112, 127, 129, 164,165

imitation (Nachahmung) 42, 153, 223 independence (Selbständigkeit) 8, 34, 37, 40, 103, 105, 119, 129, 212, 222, 231

individualism 14-17, 169, 214, 219

intellectual 41, 119, 165, 230

intelligence $29,37,60,63,105,110$, $128,155,158,233$

irony $157,159,161,203$

J

Jackson,P. 233

Jahoda,G. and I.M.Lewis 9, 220

Jay,M. 229

joke $27,33,63,137,161,189,233$

K

KAB (Katholische ArbeitnehmerBewegung) 124, 189, 191, 235

Kapferer,B. 5, 13, 71, 169, 219, 220, 232

Kaschuba,W. 48, 59

Kerschensteiner,G. 211, 221

Kimball,S. and J.H.Burnett 223

Klafki,W. 232

Knopp,G. 226

Kohl, Helmut 68, 211, 227, 228 
Kolinsky,M. 64

Konzentrationsstörung (concentration disorder) 166

Koonz,C. 25, 66, 229

Krieger,L. 23, 40, 221

Kupffer,H. 18, 24, 30, 31

Kulick,D. 223

$\mathrm{L}$

LaFontaine,J. 12

Langer,I. 230

learning $6,9,13,21,40-43,113,118$, $119,125,127,132,144,153,154,165$, 179, 199, 203, 223

lebensfähig (fit for living) 18, 19, 113, 212

Leistung (achievement) 168

Leistungsdruck (pressure to achieve) 211

lenient (nachgiebig) 37, 51

lernen (learn/learning) 40, 41, 81, 114, 125, 144, 146, 212

Lewis,G. 138

Lithman,Y. 25, 26, 233

Lohman,H-G. 17

love $8,23,33,37,39,76,88,105,157$, 172, 185, 201, 205, 212, 223, 227

Lowie,R. 4

Lukes,S. ii, 14, 40

Lunzer,E.A. 221

Lutz,C. and G.White 220

lying $8,33,81,164,174,234$

M

Mann,G. 64

Marcus,G. and M.Fischer 215, 220

Märthesheimer,P. and I. Frenzel 66

Masemann,V. 233

Max und Moritz 27, 138, 161

Mayer,P. 220 de Mause,L. 20

McDermott,R.P. 165

Mead,M. 9

Mead,M. and R.Métraux 3

Medick, H. and D.W.Sabean 225

Mensch (human/person) 13, 28, 185, 209, 211

Métraux,R. 3, 28, 33, 222

Meves,C. 29

Middleton,J. 220

Mitscherlich,A. 229

Mitscherlich-Nielsen,M. 226

model (Vorbild) 34, 35, 38, 40, 113, $140,153,169,173,228$

modern/modernity 7, 14-18, 39, 62, $68,86,122,126,174,178,181-184$, 193, 197-199, 213, 219, 229

Moore,H. 234

Mosse,G.L. 16, 25, 221, 235

motherhood 93, 104, 229

Musikverein (music association) 136, 190

Mut zum Erziehen (courage to educate/bring up) 30

$\mathrm{N}$

Nachahmung (imitation) 42 nachgiebig (lenient, give way) 37,51 nation $18,30,71,149,154,210,229$ national character $3,4,220$ National Socialism 16, 65 nature/natural $18,21-28,41,75,78$, 90, 96, 101, 103, 116, 131, 148, 171, 172 187, 188, 207, 210-214 223, 235

Nave-Herz,R. 226, 227

Neidhardt,F. 227Niethammer,L. 224

Nikolaus 133-138, 156, 177, 231, 232

Nolan,M. 224

Norman,K. 4

Novak,H. 225

NS-Zeit 67, 224,

Nurge,E. 224 
$\mathrm{O}$

obedience $8,126,131,140,161,225$ obscene 56, 172, 186, 189, 213, 230

Ochs,E. and B.Schieffelin 10, 220, 223, 233

Öhrgaard,P. i, 225

Okely,J. 222

Oma (grandmother) 6, 51, 74-76, 81, 88-94, 97, 101, 102, 108, 162, 189, 204 Ordnung (order) 7, 32, 37-40, 88, 118, $129,131,133,144,153,169,175,188$, 212,222

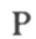

pedagogics $19,21,22,113,116,124$, $125,223,230,232,233$

pedagogue $24,108,126,154-156,167$, 168, 221

Pestalozzi 22

Piaget 21, 221

pleasure $99,103,130,172,188,212$,

213,234

politics $6,58-60,177,180,210,225$, 235

Pollock,L. 20

praise $32-34,136-138,140,147,153-$ 157, 167-169, 216

Pross,H. 222,229

Protestant 62, 177, 203

Prussia 62

punishment 21, 32, 33, 126, 133, 136, $138,140,146,155-158,161,168,216$, 222

pupil (Schuler) 148, 149

$\mathrm{R}$

Rabinbach,A. 68

RAF(Rote Armee Fraktion)/terrorists $15,37,66,71,213$ reality $10,33,97,103,119,122,128$, 164, 174, 212

Realschule (secindary school) 150 , 200

Rechtschreibung (correct, good spelling/writing) 153, 154, 233

Rechtsstaat (state of law) 18, 65, 71 religion $55,121-124,170-174,182$, 183, 196, 200-202, 235

responsibility $33,37,68,72,77,89$, $100,104,124,145,184,201,225$

reward 26, 33, 42, 156

Riesman,P. 11, 220

Ringer,F. 16, 221, 232

Roberts,J. and S. Akinsanya 232

Rodnick,D. 4, 40

Roggenkamp,G. 2

Rosaldo,M. 11, 220

Roth,P. 215

Rousseau,J-J. 21, 22, 24, 221, 222

Rutschky,K. 20, 24, 26, 30, 209

S

Sabean,D.W. 48

Sagarra,E. 54, 234

Sahlins,M. 224

sarcasm 152, 161, 203

sauber (clean of work; of toilet-training) $97,129,159$

Schatzmann,M. 26

Schildkrout,E. 9, 10, 220

Schiller 184, 235

Schleiermacher 222

Schnuller (pacifier) 98

Schreber,D.G.M. 22, 25, 26, 28

Schrebergarten 26

Schuld (fault, guilt, blame) 11, 33, 36, 68,167

Schuiler (pupil) 148

Schultüte (school bag/cone) 146, 149

Schultze,W. and C.Führ 150 
Schürtze (apron) 80

Schwartzmann,H. 220

Second World War 3, 63, 218, 226

Selbständigkeit (independence) 37 -

39, 114, 118, 212

self-cultivation (Bildung) 21, 41

sexuality 170-173, 184-188, 199, 213, 234

Siebert,J. 64

social history 48

socialization 5, 9-11, 220, 221, 226, 233

Sommerkorn,I. 92, 229

Sonderschule (special school) 151

Sontheimer, K. 23

SPD 46, 60, 65, 151

Spencer,J. 215

Sperber,D. 215

Spindler,G. 4, 53, 220, 223, 229, 230, 232

Sportverein (sports association) 59, 177, 180, 190

State 1, 5, 18-23, 30, 31, 53, 61, 64, 65, 70-74, 145, 149, 153, 169, 203, 208, 210-213, 221, 228, 235

Strathern,M. 12, 13, 153, 220, 228, 229

Struwwelpeter 27, 213, 232

Sweden 63, 218, 221

sweets 99, 101, 103, 131, 136, 137, 146, 149, 168, 212

$\mathrm{T}$

teasing $27,28,116,137,157,159,161$ tell-taling/tattling 116, 117, 130, 139142

Thirty Years War 62, 63

Tonkin,E. et al. 224

Toren,C. 220
$\mathrm{U}$

unity $18,40,71,88,105,113,169,210$, 211, 231

V

Varma,V. and P.Williams 221

Veranlagung (heredity) 29, 36, 169

Vereine (voluntary associations) 5 , $55,59,61,224$

verwöhnt (spoiled) 37, 118

Volkskunde 48

Vorbild (model) 34, 35, 37, 42, 170, 173

W

Warren,R. 4

Weatherford,J. 2, 4, 228, 229

Weber,M. 221, 225

Weber-Kellermann,I. 45, 227, 231

Weil,S. 232

Weinberg,D. 229

whole/wholeness (das Ganze) 18, 22, 23, 40, 53, 169, 209, 211, 214, 222

wildness/wild places $38,39,62,164$, 214

Wolcott,H. 223

Wolff,H. 50, 64

Wörner,G. 51

Wulff,H. 233

Wünsche,K. 150, 233

$\mathrm{Y}, \mathrm{Z}$

Young,M. and P.Willmott 89, 228

Zugezogen(e) (newcomer/in-mover) $56,59,228$ 


\section{Stockholm Studies in Social Anthropology}

1. Caymanian Politics: Structure and Style in a Changing Island Society by Ulf Hannerz. 1974.

2. Having Herds: Pastoral Herd Growth and Household Economy by Gudrun Dahl and Anders Hjort. 1976.

3 The Patron and the Panca: Village Values and Pancayat Democracy in Nepal by Bengt-Erik Borgström. 1976.

4. Ethnicity and Mobilisation in Sami Politics by Tom Svensson. 1976.

5. Market, Mosque and Mafraj: Social Inequality in a Yemeni Town by Tomas Gerholm. 1977.

6. The Community Apart: A Case Study of a Canadian Indian Reserve Community by Yngve G. Lithman. 1978. (Available from the University of Manitoba Press).

7. Savanna Town: Rural Ties and Urban Opportunities in Northern Kenya by Anders Hjort. 1979.

8. Suffering Grass: Subsistence and Society of Waso Borana by Gudrun Dahl. 1979.

9. North to Another Country: The Formation of a Suryoyo Community in Sweden by Ulf Björklund. 1981.

10. Catching the Tourist: Women Handicraft Traders in Gambia by Ulla Wagner. 1982.

11. The Practice of Underdevelopment: Economic Development Projects in a Canadian Indian Reserve Community by Yngve G. Lithman. 1983.

12. Evil Eye or Bacteria: Turkish Migrant Women and Swedish Health Care by Lisbeth Sachs. 1983.

13. Women of the Barrio: Class and Gender in a Colombian City by Kristina Bohman. 1984. 14. Conflict and Compliance: Class Consciousness among Swedish Workers by Mona Rosendahl. 1985.

15. Change on the Euphrates: Villagers, Townsmen and Employees in Northeast Syria by Annika Rabo. 1986.

16. Morally United and Politically Divided: The Chinese Community of Penang by Claes Hallgren. 1987.

17. In the Stockholm Art World by Deborah Ericsson. 1988.

18. Shepherds, Workers, Intellectuals: Culture and Centre-Periphery Relationships in a Sardinian Village by Peter Schweizer. 1988.

19. Women at a Loss: Changes in Maasai Pastoralism and their Effects on Gender Relations by Aud Talle. 1988.

20. First We Are People...: The Koris of Kanpur between Caste and Class by Stefan Molund. 1988.

21. Twenty Girls: Growing Up: Ethnicity and Excitement in a South London Microculture by Helena Wulff. 1988.

22. Left Hand Left Behind: The Changing Gender system of a Barrio in Valencia, Spain by Britt-Marie Thurén. 1988.

23. Central Planning and Local Reality: The Case of a Producers Cooperative in Ethiopia by Eva Poluha. 1989.

24. A Sound Family Makes a Sound State: Ideology and Upbringing in a German Village by Karin Norman. 1991 




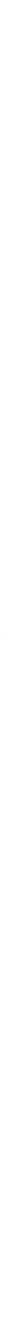

